\title{
Yārıstān - die Freunde der Wahrheit: Religion und Texte einer vorderasiatischen Glaubensgemeinschaft
}

\author{
Dissertation \\ zur Erlangung des philosophischen Doktorgrades an der Philosophischen Fakultät der \\ Georg-August-Universität Göttingen
}

vorgelegt von

Behrouz Geranpayeh

aus Hamadan (Iran) 


\section{Danksagung}

Die vorliegende Arbeit ist nur dank der Unterstützung und Hilfe vieler Menschen zu Stande gekommen.

Ohne die handschriftliche Sammlung der Yāristān-Literatur und -Mythen, die das Lebenswerk meines geistlichen Lehrers Säyyed Kāżem Nīknežād, des Pir der Yādıgārī-Dynastie sind und die mir zur Verfügung stand, wäre mein wissenschaftliches Vorhaben nicht möglich gewesen. Ich bedanke mich ebenso bei meiner Familie im Iran, die mir den Zugang zu Säyyed Kāżem Nīknežād über die Jahre offen hielt und den Kontakt mit ihm ermöglichte.

Ohne die persönliche Unterstützung durch Professor Philip Kreyenbroek, den Direktor des Instituts für Iranistik an der Georg-August-Universität Göttingen, wären meine Erfahrungen mit der religiösen Gemeinschaft Yārıstān (bzw. der Ähl-1 Häqq ) unentdeckt geblieben. Sein einzigartiges wissenschaftliches Interesse an die Ähl-1 Häqq verschaffte mir die Anregung, meine empirischen Erkenntnisse über die Existenz und die Weltanschauung der Ähl-1 Häqq in Form einer wissenschaftlichen Untersuchung darzustellen.

Ohne die akademische Anleitung durch Professor Milan Adamovic, den Direktor des Seminars für Turkologie und Zentralasienkunde an der Georg-August-Universität Göttingen bei der Entwicklung von Transkriptionszeichen für die in der Promotionsarbeit behandelte Mundart des Türkischen wäre dieser Arbeitsabschnitt schwierig zu realisieren gewesen.

Ebenso bedanke ich mich bei Golmorad Moradi, Ph. D., bei Michael Plaumann, bei der ev.-luth. Pastorin Christiane Scheller, bei Tina Hammoud, bei Ulrike Kempf und vielen andren für ihre private Unterstützung.

Göttingen, den 01.02.2006 


\section{Inhaltsverzeichnis}

$\begin{array}{lc}\text { I. Zur Problemstellung } & 6\end{array}$

1. Stand der Forschung und Zielsetzung 6

2. Zur Quellenlage $\quad 8$

3. Herkunft des Textes und Methoden der Textuntersuchung 11

$\begin{array}{ll}\text { II. Geschichte, Verbreitung, Prinzipien der Yārıstān } & 17\end{array}$

1. Die Sagen und die Mythen über die Weltentstehung 17

1.1. Die Weltentstehung in der Yārıstān-Darstellung 18

1.2. Die Geschichte der Yārıstān 38

2. Die Verbreitung der Yārıstān $\quad 50$

3. Die Prinzipien der Yārıstān 53

3.1. Die Weltanschauungsprinzipien 53

a) Wahrheit (Gott) 53

b) Seelenwanderung $\quad 57$

c) Weltrettung durch die Yārıstān $\quad 58$

3.2. Die Moralprinzipien 62

a) Šärț und Iqrār (,„der Pakt“ und „,die Verpflichtung“) 62

b) Hifz-e Äsrār (,,die Bewahrung der Geheimnisse der Yārıstān bis zum Tod“") und Täqyyä (,die Verheimlichung“) $\quad 63$

c) das soziale Gewissen der Gemeindemitglieder $\quad 67$

4. Zu den Relationen zwischen der religiösen Doktrin und dem praktizierten Glauben der Yārıstān 
IV. Rituale und Bräuche

1. Jahresfeste $\quad 82$

2. Rituale aus einem besonderen Anlass 93

a) die Namensgebung 93

b) die Initiation (Särsı̄pāī ) 93

c) die Hochzeit 94

d) die Beerdigung 95

3. Gebete 97

4. Vorschriften 101

V. Die Yārıstān und die Musik 104

$\begin{array}{ll}\text { VI. Transkriptionen und Übersetzungen } & 111\end{array}$

$\begin{array}{ll}\text { VII. Zusammenfassung und Aussicht } & 216\end{array}$

$\begin{array}{lr}\text { VIII. Literaturverzeichnis } & 218\end{array}$ 


\section{Vorbemerkung}

Die Religion der Yārıstān (Ahl-e Haqq ${ }^{1}$ ) - ist eine iranische Religion, die in ihren heiligen Gedichten und Reden, Liedern und Ritualen im mittleren Osten sehr eigene Besonderheiten aufweist. Die mündliche Literatur der Yārıstān, die auch die Beschreibung ihrer Rituale einschließt, ist in Gūrānī, in Persisch und in Lorisch sowie in einer türkischen Mundart ${ }^{2}$ überliefert.

Die Inhalte ihrer Lehre - der Mythologie, der Weltanschauung und der Moral - bieten eine originale Quelle für die Erforschung dieser im Iran, im Irak, in Turkmenistan und in der Türkei verbreiteten Kultur.

Die Religion der Yārıstān, die in der islamischen Welt des Mittleren Ostens verbreitet ist, ist weder eine Sekte noch ein Zweig des islamischen Glaubens. Dafür sprechen die folgenden Hauptmerkmale der Anschauungen, die diese Religion als eigentümlich hervorheben und ihn grundsätzlich vom Islam unterscheiden:

- die Seelenwanderung (Reinkarnation) mit dem Ziel der Wandlung zu einem reinen Menschen und seiner Vereinigung mit der Wahrheit (dem Schöpfer),

- die Abwesenheit der Vorstellung von Paradies und Hölle im Yārıstān-Glauben,

- die Begleitung mancher Rituale mit Musik und Gesängen.

Die vorliegende Untersuchung der Texte, der sozialen Struktur, der Vorschriften, Rituale und Musik der Yārıstān wurde von mir, als Mitglied einer Yārıstān-Familie’3, aus der Sicht eines teilnehmenden Beobachters, der sich der wissenschaftlichen Arbeit und der systematischen wie methodischen Erforschung dieser Religionsgemeinschaft verpflichtet sieht, durchgeführt.

Durch meine direkten Kontakte zu den Geistlichen und Autoritäten der Yāristān habe ich die mündlichen Überlieferungen, die seit über 60 Jahren von einem zeitgenössischen

\footnotetext{
${ }^{1}$ Die Anhänger der Religionsgemeinschaft der Ahl-e Ḥäqq (pers.) - „Menschen der Wahrheit“ bezeichnen sich selbst mit unterschiedlichen Namen: Ähl-ı Häqq (türk.), Yārān (Pluralform von Yār; im Persischen, wie auch im Türkischen bedeutet „ein lieblichster Freund“, „ein Geliebter“, „ein herzlicher Helfer"), Yārsān (bedeutet im Gūrān̄ischen dasselbe wie Yārlstān), Yārlstān („,die zum Yār gehören“),Ṭāyfa (im Persischen, im Gūrānīschen, im Türkischen und im Arabischen bedeutet „ein Stamm“ oder „ein Volk“), Ṭâyfasān („,die zum Țāyfa gehören“) und andere (mehr dazu siehe in Hamzeh'ee, Reza M. 1990).

${ }^{2}$ Die Familie des Verfassers gehört der türkischsprachigen Tradition an.

${ }^{3}$ Die Ähl-1 Ḥäqq-Familie ist die kleinste soziale Einheit innerhalb einer Ähl-1 Ḥäqq-Xānı̄ān (Dynastie). Nach Angaben von Pīr Säyyed Kāżem Nīknežād gibt es 16 Ähl-1 Ḥäqq-Xānıdān, die im Folgenden aufgelistet werden.
} 
Pīr-1 Xānıdān ${ }^{4}-1$ Yādıgārī̄, Säyyed ${ }^{6}$ Kāżem Nīknežād, gesammelt und niedergeschrieben wurden, erhalten.

Da ich bis zu meinem 20. Lebensjahr persönlich an Ritualen der Yārıstān teilgenommen habe, konnte ich meine eigenen Erfahrungen mit der Yārıstān-Religion für die Arbeit verwenden.

\footnotetext{
${ }^{4}$ Pīr-1 Xānıdān (türk.) oder Pīr-e Xāndān bzw. Pīr-e Dūdemān bzw. Pīr-e Dūdeh (pers.) bedeutet „Sippenführer“. Ein Pīr (pl. Pīrān) ist gleichzeitig ein „Priester“, ein Lehrer, ein Anführer, einer, der alle heiligen Gedichte auswendig kann. Er ist das Oberhaupt einer Ähl-1 Ḥäqq-Xānıdān.

${ }^{5}$ Xānıdān-1 Yādıgārī ist eine der 16 Ähl-1 Ḥäqq-Xānıdān.

${ }^{6}$ Säyyed (arab.) ist ein anderes Wort für Pīr (pers.).
} 


\section{Zur Problemstellung}

\section{Stand der Forschung und Zielsetzung}

Im Jahre 1902 hatte der russische Professor Valentin A. Žukovskij ${ }^{7}$ seinen damaligen Studenten Vladimir Minorsky ${ }^{8}$ mit der Erforschung der „'Alî-ilâhî‘ ${ }^{(69}$-Gemeinde im Iran beauftragt. Die Ergebnisse der langjährigen Forschung im Iran wurden im Bericht „Материалы для изучения персидской секты „Люди истины“ или Али-илахи“ in „Труды по востоковедению, издаваемые Лазаревским Институтом Восточных языков“" ${ }^{10}$ in Moskau im Jahre 1911 veröffentlicht. Minorsky schrieb, dass er zum ersten Mal über die Existenz der Religion „'Alî-ilâhî“ durch die Werke von V. A. Žukovskij erfahren habe. Zu Anfang seiner Reise in den Iran im Jahre 1902 habe ihm nur eine einzige von Žukovskij im Jahre 1886 in Schiras (der Hauptstadt der Provinz Fārs im Iran) entdeckte Quelle zur Verfügung gestanden, die aus nur unpräzise notierten Gedichten bestand, deren Echtheit jedoch durch 34 Gläubige bestätigt worden war. Während eigener Reisen in den Jahren 1902-1906 hat Minorsky die Materialien vervollständigt. Der Wissenschaftler hat z. B. eine 136-seitige Handschrift von dem sog. „Buch Serenjām“"11 im Iran gekauft. Die sehr sorgfältige Übersetzung dieser Handschrift hat er mit eigenen Kommentaren sowie mit einigen selbst gemachten Fotos von den heiligen Gräbern der Gemeindelehrer in Makū und Hamadān in seinem Bericht veröffentlicht (vgl. Minorsky 1911, S. 7ff.). In seinem Bericht wurden eine religiöse Rede und fünf Gedichte in ihrer Originalsprache mit Übersetzung vollständig publiziert. Das „Aserbaidschanische“ dieser Texte bezeichnet Minorsky als „eine türkische Mundart" ${ }^{\text {"12 }}$, obwohl sie „wesentliche Abweichungen von dem Aserbaidschanischen sowohl in der Form als auch wahrscheinlich in der Phonetik darstellt" (vgl. Minorsky 1911, S. 67).

Diese Mundart des Türkischen hat bis dato tatsächlich keine Eigenbezeichnung und kann durch seine Verbreitung als mittel-west-iranisches Türkisch bezeichnet werden,

\footnotetext{
${ }^{7}$ Valentin Aleksejevič Žukovskij (1858 - 1918) - russischer Iranist, Professor, Mitglied der St.Petersburger Akademie der Wissenschaften, Spezialist für die persische Sprache und Dialekte, persische Literatur und Folklore, persische Ethnographie und Geschichte.

${ }^{8}$ Vladimir Fjodorovič Minorsky $(1877$ - 1966) - russischer Orientalist, der später in Frankreich und in England lebte; seit 1937 Professor an der Londoner Universität.

9" Alî-ilâhî'- wörtlich heißt „,Ali ist Gott" - nennen die Muslime die Ähl-1 Häqq -Gemeinde. Ähl-1 Häqq selbst empfinden diese Bezeichnung als Erniedrigung. Die Transkription dieses Wortes stammt von V. F. Minorsky.

${ }^{10}$ „Materialien für die Untersuchung der persischen Sekte „Menschen der Wahrheit“ oder „,'Alî-ilâhî“" in „Werke der Ostwissenschaft des Lasarevskij Instituts der Östlichen Sprachen“. Heft XXXIII

${ }_{11}$ „Buch Serenjām“ - „Buch der Erfüllung“.

${ }^{12}$ Diese Mundart unterscheidet sich von der in dieser Arbeit behandelten Mundart des Türkischen in der Phonetik, während die Grammatik und die Syntax überwiegend gleich sind.
} 
weil sie in den mittel-west-iranischen Provinzen Hamadān, Zanjān, Qazwīn und in der Stadt Sāveh (Provinz Teheran) gesprochen wird.

Minorsky stellte die Authentizität der publizierten religiösen Reden im Unterschied zu den fünf Gedichten fest. Die Gedichte bezeichnet er als „Beispiele der frommen

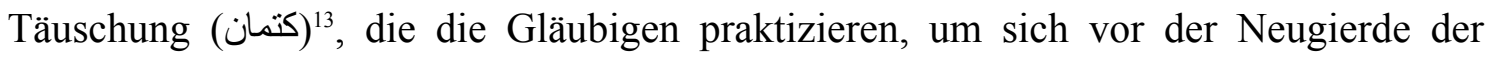
Außenstehenden zu verbergen“" (vgl. Minorsky 1911, S. 68). Alle Reisenden und Forschungsreisenden, so V. F. Minorsky in seinen „Materialien“ (1911, S. 8), die bis zur Gegenwart über die 'Alî-ilâhî, deren Eigenbezeichnung „Menschen der Wahrheit“" lautet, geschrieben haben, wiesen übereinstimmend auf die Zurückgezogenheit der Anhänger dieser Gruppe hin. Die Erklärung dafür ist die Jahrhunderte dauernde ethnische, religiöse und wirtschaftliche Unterdrückung der Ähl-1 Ḥäqq, die auch bewirkt hat, dass sie sich selbst als „Elende“ ('yoxsol'- türk. ${ }^{14}$, 'häžār'- kurd. ${ }^{15}$ ), „Hungrige“ ('â̂’’ türk.), „Mittellose“ ('gıčdux küll-1 vardän’- türk) ansehen (siehe z. B. Kälāmāt ${ }^{16}$ Nr. 12, 31, 36).

Die Ähl-1 Häqq haben bis zum Ende des 20. Jahrhunderts ihre mündliche Literatur und ihre Rituale mit Sorgfalt beibehalten. Zum einen versucht die islamische Regierung des Iran, die Ähl-1 Häqq der Öffentlichkeit als eine schiitische Gemeinschaft darzustellen (Yasemi, R. 1936; Nour Ali Elahi 1974; Safizadeh 1997 a.; 1983; Jeyḥunābādi Ne mät ollāh 1985; Brockhaus 2004). Die tatsächlichen Inhalte des Glaubens der Ähl-1 Ḥäqq werden dadurch falsch dargestellt. Zum anderen stellten sich die Ähl-1 Häqq selbst nach außen auch als eine schiitische Sekte dar, um sich zu tarnen und so überleben zu können.

Das Buch „Šenāxt-e Ähl-1 Ḥäqq “17 von Abdullah Xodābändeh (2004) ist ein aussagekräftiges Beispiel dafür, wie sich die religiöse Gemeinschaft der Ähl-1 Häqq noch heute einem Fremden gegenüber als eine schiitische Sekte darstellt. Der Autor ist ein islamischer Scheich, der als Theologiewissenschaftler den Zugang zur Ähl-1 Ḥäqq Gemeinde zu finden versucht. Alle seine Kontakte zu den Ähl-1 Ḥäqq -Angehörigen haben ihn überzeugt, dass sie schiitische „Extremisten“ ('g golāt' - arab.) sind, weil sie ‘Alī als Gott anerkennen und nicht Allāh (vgl. Xodābändeh 2004, S. 75f.). Dabei stützt er sich auf die Meinungen berühmter Iranforscher wie A. Gobineau, V. F. Minorsky,

\footnotetext{
13 كتمان [k1tmān] heißt „Bewahrung eines Geheimnisses“.

${ }^{14}$ Die Transkriptionszeichen für die hier behandelte türkische Mundart werden im Weiteren eingeführt.

${ }^{15}$ Das kurdische Wort 'häžār' kommt in den türkischen Kälāmāt auch vor.

${ }^{16}$ Kälām (pl. Kälāmāt) heißt im Yārıstān-Lexikon ,,heiliges Gedicht“.

17 „Šenāxt-e Ähl-1 Ḥäqq “ - wörtlich ,, Das Studium über die Ähl-1 Ḥäqq “.
} 
V. A. Žukovskij, V. A. Ivanow, I. P. Petruševskij, die die Merkmale der Ähl-1 Ḥäqq in ihren Werken nannten, die für die islamische Herkunft der Ähl-1 Häqq sprächen (vgl. Xodābändeh 2004, S. 65). Und wenn man aber die von Abdullāh Xodābändeh zitierten Stellen aufmerksam liest, sieht man, dass die zitierten Autoren nicht zu dem Schluss kamen, dass Ähl-1 Häqq eine islamische Sekte sei, sondern überhaupt davon absahen, diese Religion irgendwie einzuordnen.

Aufgrund der Verschlossenheit und des Fehlens schriftlicher Texte der Ähl-1 Häqq ist die Erforschung der Geschichte und die Erläuterung von ethischen und praktischen Prinzipien dieser Religionsgemeinschaft äußerst schwierig. Es finden sich einige Monographien und Aufsätze, die entweder gewisse Aspekte dieser Religionsgemeinschaft untersuchen (Bruinessen 1991, S. 55-73), oder die die Ähl-1 Häqq als eine neben anderen Religionen und Sekten einer bestimmten Region behandeln (Hamzeh'ee 1992, Kreyenbroek 1996; 1998).

So gesehen leistet die vorliegende Arbeit einen wichtigen Beitrag: sie behandelt eine bisher kaum bekannte Religion. Die mündliche Überlieferung der heiligen Texte der Ähl-1 Häqq in einer türkischen bzw. aserbaidschanischen Mundart war bisher in ihren Einzelheiten ebenfalls kaum erforscht (nur im Werk V. F. Minorskys). Daher ist es das Ziel dieser Arbeit, das Wissen über diese Religion zu vervollständigen und die handgeschriebene Sammlung der heiligen Texte der Ähl-1 Häqq (bzw. der Yārıstān, wie sich die Gläubigen selbst gerne nennen) eines zeitgenössischen Pīr-1 Xānıdān, Kāżem Nīknežād, zum ersten Mal der Wissenschaft und der Öffentlichkeit vorzustellen.

\section{Zur Quellenlage}

Als Quelle haben mir zum Teil meine eigenen Erfahrungen, die ich in der Kindheit und Jugend gemacht habe, gedient. Schon damals stellte ich mir die Frage, warum andere, z. B. die Nachbarkinder oder Schulkameraden, über meine Religionszugehörigkeit nichts erfahren durften, oder wieso mein Vater mit der Bezeichnung „ ¿Älī-Ällāh̄̄“ von den Muslimen beschimpft wurde. Aber bewusst ist mir meine Religion erst geworden, als ich im Jahre 1966 zum Augenzeugen einer heftigen Diskussion zwischen Kāżem Nīknežād (geb. 1919), dem Führer der Xānıdān-ı Yādıgārī, und Nour ‘Älī Ilāhī (18961975), dem Anhänger einer anderen Xānıdān namens Bābāhäyāsī über den islamischen bzw. schiitischen Ursprung der Yārıstān wurde. Nour 'Älī Ilāhī war der Auffassung, dass die Yārıstān einen schiitischen Ursprung habe. 
Nour ‘ ̈̈lī Ilāhī wurde von Yārıstān-Gläubigen isoliert und blieb im Kreis seiner Verwandten in Teheran bis zu seinem Tod. Die Grabstätte des Nour 'Älī Ilāhī befindet sich in Haštgerd, einer kleinen Stadt zwischen Teheran und Qazwīn. Ilāhīs heutige Anhänger, die durch die Regierung der Islamischen Republik Iran tatkräftige Unterstützung erfahren, versuchen, durch Terror die Ähl-1 Häqq Haštgerds, die einen sehr hohen Anteil der Bevölkerung ausmachen, aus der Stadt zu vertreiben. Die Immobilien der Geflohenen werden zu Niedrigpreisen aufgekauft und den immer zahlreicher zuziehenden Anhänger Ilāhīs zugeschoben.

Im Jahre 1969 erfuhr ich, dass Pīr Kāżem Nīkežād seit Jahren unsere heiligen, bislang mündlich überlieferten Gedichte aufschrieb. Diese sind auf Türkisch überlieferte Texte der Ähl-1 Häqq . Es gibt auch eine Gūrānīsche Überlieferung der heiligen Texte der Ähl1 Ḥäqq, die „Zäbūr-1 Ḥäqīqät“" heißt. Sie wurde im Jahre 1959 von Derwisch Yārmorād handschriftlich zusammengestellt und besteht aus 2090 Seiten. Darüber berichtet Golmorad Moradi in seinem Buch ,Ein kurzer Einblick in die Geschichte und Philosophie der Ähl-1 Ḥäqq (Yārıstān)“) (1999).

Das Werk von Kāżem Nīkežād besteht aus zwölf handgeschriebenen Heften. Die heutigen Gelehrten der Yāristān haben die Zugehörigkeit dieser Hefte zum Überlieferungskanon ihrer Religion bestätigt.

Auf Grund dessen, dass die Überlieferung lange Zeit lediglich mündlich erfolgte, entwickelten sich viele Varianten des Textes von Däftär-e Kälām ${ }^{18}$. Außerdem hat jede Xānıdān eine andere Version von Däftär-e Kälām in ihrem Besitz. Trotz dieser Varianten bleibt der inhaltliche Kern aber weitgehend unberührt. Ich habe das Glück, eine Kopie von Däftär-e Kälām, zu besitzen. Sie umfasst nach Meinung des Sammlers, P̄̄r Kāżem Niknežād, die wichtigsten Texte der Däftär-e Kälām, die bis jetzt nur aus dem Gedächtnis der Pīrān mündlich überliefert worden sind. Dieses Heft, das den Titel „Kälāmāt-1 torkî‘ ${ }^{-19}$ trägt, wurde in geringer Anzahl angefertigt und manchen YārıstānFamilien, u. a. meiner Familie, übergeben.

Diese Schrift bildet die Hauptquelle der von mir vorgelegten Untersuchungen.

\footnotetext{
${ }^{18}$ Däftär-e Kälām (pers.) bedeutet wörtlich „,das Heft des religiösen Gedichtes“. Varianten des Textes der Däftär-e Kälām sind nur in Bruchstücken schriftlich, sonst mündlich überliefert.

19 „Kälāmāt-1 torkī“ sind Kälāmāt auf Türkisch. So hat Pīr Kāżem Niknežād seine handgeschriebene

Sammlung der Kälāmāt genannt.
} 


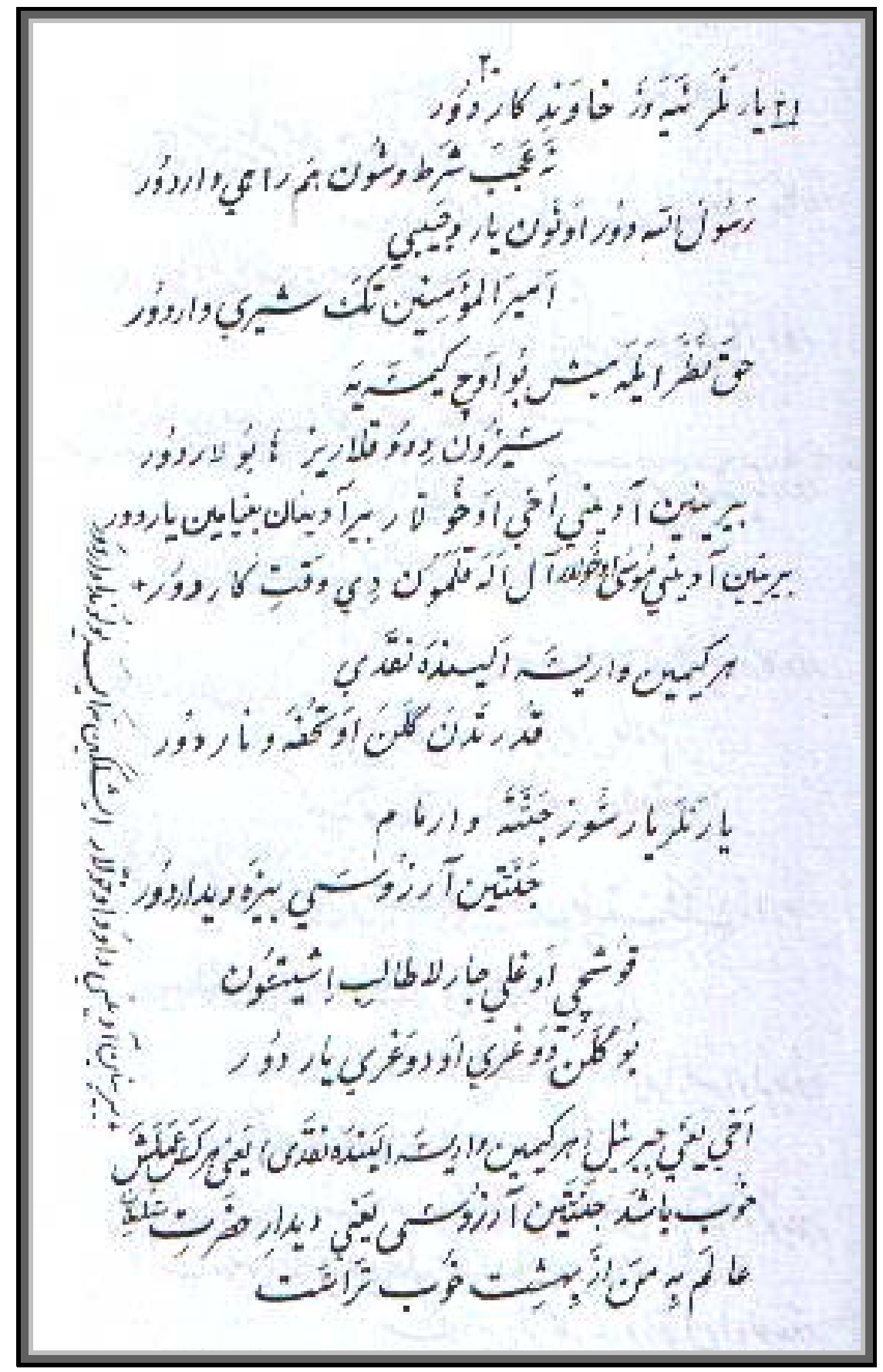

Kälām Nr. 21 aus der Handschrift der „Kälāmāt-1 torkīi“ von Säyyed Kāżem Niknežād 
Da die Musik ein wichtiges Element der Rituale der Yārıstān ist, bot sie sich mir als eine weitere Forschungsquelle an. Es gibt zwei Musikarten in der Yārıstān: die heilige Musik und die freie Musik für den alltäglichen Gebrauch.

Die freie Musik ist aufgrund ihrer Zugänglichkeit für die Musikethnologen recht gut erforscht. Die heilige Musik stellt weiterhin ein reiches Forschungsfeld für die Musikwissenschaftler dar. Einige Kassetten mit Aufnahmen der die 'Mūsīqī-e Kälāmī' (,heiligen Musik“) begleitenden Rituale befinden sich in meinem Besitz und wurden in die Forschung ebenfalls einbezogen.

\section{Herkunft des Textes und Methoden der Textuntersuchung}

Da die Überlieferung der Yārıstān-Lehre Jahrhunderte lang lediglich auf mündlichem Wege geschah, wurde sie zur einer Art Familienerbe und heißt „Däftär-e Kälām“. Die Lehre wurde vom Pīr entweder an den fähigsten seiner Söhne oder an einen seiner Brüder, oder einen anderen männlichen Verwandten weitergegeben.

Diese religiöse Tradition besteht nicht nur aus den heiligen Gedichten, sondern auch aus einem anderen, sehr wichtigen, Teil - den $\operatorname{Reden}^{20}$, die von dem Pīr im Laufe der jährlichen Rituale und Veranstaltungen im Jäm-Xāna ${ }^{21}$ gehalten wurden. Themen der Kälāmāt und der Reden sind die Weltanschauung der Yārıstān, ihre Mythologie, Heldentaten sowie Erzählungen über ihre Geschichte.

Diese Kälāmāt und Reden wurden von meinem geistlichen Lehrer Kāżem Nīknežād, dem Pīr der im Iran lebenden Türkisch sprechenden Xānıdān-1 Yādıgārī, niedergeschrieben. Er ist bis dato der einzige Sammler von türkischen Gedichten, Reden und Dokumenten der Yārıstān. Diese Sammlung umfasst nach seiner Aussage 12 Handschriften $^{22}$. Die zusammengestellten Texte hat Säyyed Kāżem Nīknežād an die anderen Pīrān weiter gegeben, um sie zu vervollständigen. Dafür hat er mehrere Reisen unternommen und sich mit vielen der heutigen Pīrān und Kälāmāt-Kenner getroffen. Diesen Prozess, der seit dem Jahr 1955 in Hamadān, Teheran, in iranischem Kurdistan, in Loristan und in Aserbaidschan stattfindet, habe ich bis 1980 selber miterlebt, seitdem habe ich an dem Prozess über Familienkontakte weiter Anteil gehabt. Die Sammlung von türkischen Kälāmāt war von Säyyed Kāżem Nīknežād handgeschrieben und beinhaltet 330 Kälāmāt von 24 Dichtern.

\footnotetext{
${ }^{20}$ Reden („Xäțāba“ - arab., türk. und pers.) sind mit den Predigten vergleichbar.

${ }^{21}$ Jäm-Xāna (türk., pers., kurd.) heißt wörtlich „Versammlungshaus“. Jäm bedeutet im Yārıstān-Lexikon „Versammlung“" und/oder „Versammlungshaus“.

${ }^{22} 6$ von diesen 12 Handschriften befinden sich in meinem Besitz.
} 


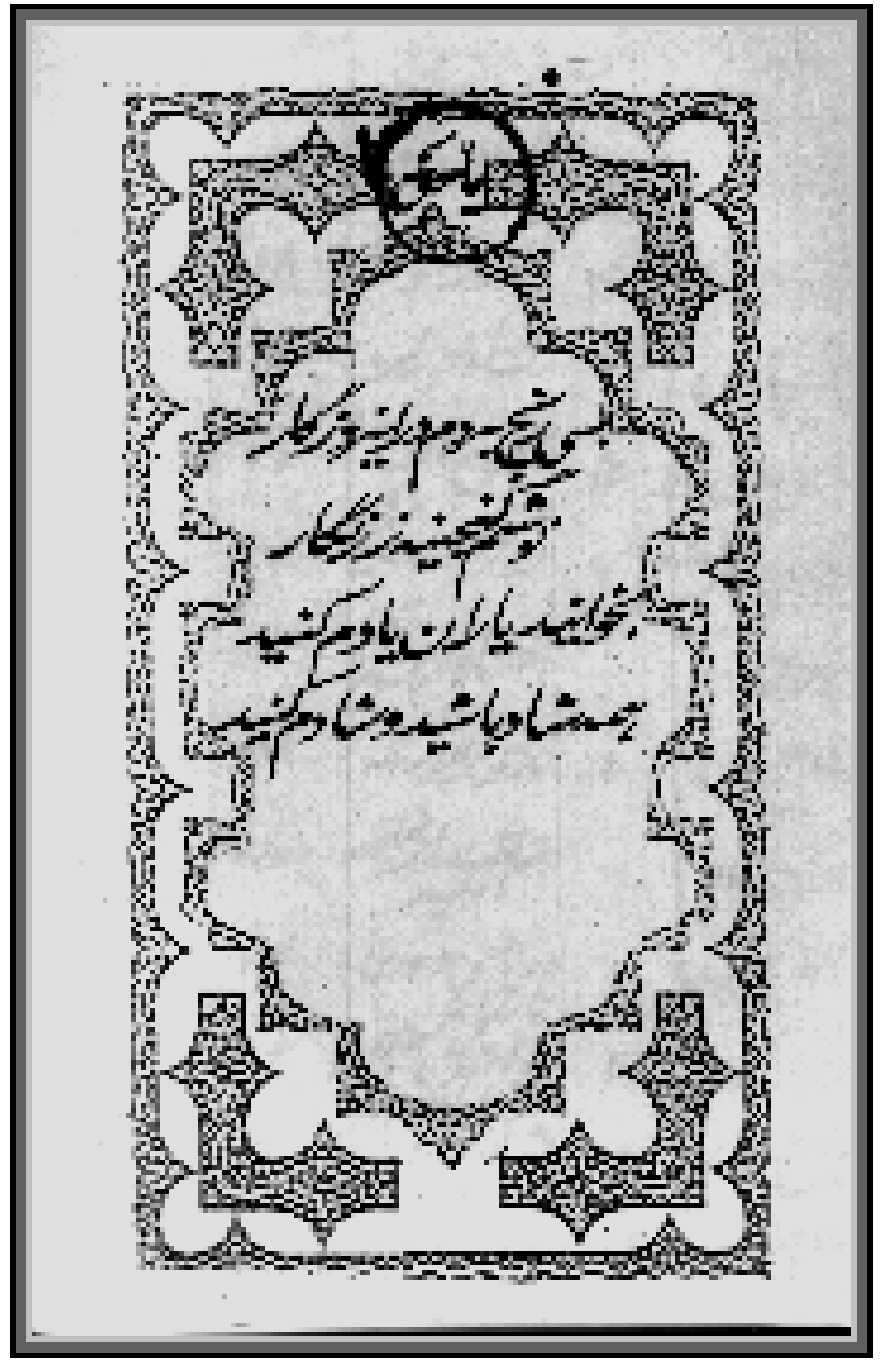

Die Titelseite des Buches „Gänj̄inneh-e Zärnegār"“ mit einer Inschrift „O, Wahrheit!“ und einem Gedicht von Säyyed Kāżem Nīknežād:

1. Ich gab mir in den langen Jahren viel Mühe,

2. Ich schrieb die „Gänĵ̄neh-e Zärnegār““,

3. Lest ihr, Yārān, dieses Buch durch und erinnert euch an mich.

4. Seid alle fröhlich und mit eurer Freude macht ihr mich ebenso fröhlich. 
Einen Hinweis auf die persischen Handschriften der Reden vom Säyyed Kāżem Nīknežād sah ich im Jahre 2004 bei G. Moradi (1999) zum ersten Mal und wendete mich an Herrn Moradi. Er schickte mir freundlicherweise zwei Handschriften:

1. Äsrār-e Yārī („Geheimnisse der Yārıstān”),

2. Āyīn-e Yārī („Doktrin der Yārıstān“).

Vier weitere erhielte ich vom Säyyed Kāżem Nīknežād selbst:

3. Gänĵ̄nneh-e Yārī („Schatz der Yārıstān“),

4. Gänj̄inneh-e Zärnegār („Mit Gold geschmückter Schatz“),

5. Kälāmāt-1 torkī,

6. Āṣār-e Yārī (,Spuren der Yārıstān“).

Die Zielsetzung, die handgeschriebene Sammlung der heiligen Texte der Yārıstān den westlichen Forschern zu erschließen, verlangte die Übersetzung und das Kommentieren der einzelnen Gedichte, religiösen Reden und Erzählungen. So werden 72 ausgewählte ${ }^{23}$ heilige Gedichte transkribiert, aus der Mundart des mittel-west-iranischen Türkischen ins Deutsche übersetzt, die in den Gedichten enthaltene Begrifflichkeit gedeutet und die Inhalte der Texte aus kultur-geschichtlicher Sicht erklärt.

\section{- Die Transkription}

Bei der Bestimmung der Zeichen wurden folgende Bedingungen herangezogen:

- die Zeichen sollten möglichst einfach zu lesen sein und

- sie sollten die Aussprache möglichst genau wiedergeben.

Während die erste Bedingung relativ leicht zu erfüllen war, erwies sich die zweite Bedingung als schwierig zu realisieren. Die behandelte Mundart ist eine Mischung mehrerer bekannter Sprachen: 1) des Türkei-Türkischen und der Turksprachen wie hauptsächlich des Aserbaidschanischen, des Osmanischen und auch verschiedener türkischer Dialekte, 2) des Persischen, 3) des Gūrānīschen und 4) des Arabischen. Diese Mischung zeichnet sich nicht nur durch Lexikon und Syntax, sondern auch durch die Aussprache einzelner Laute und die Betonung einzelner Worte aus. Diese Tatsache, dass die Phonetik der behandelten Mundart wesentliche Unterschiede zu den bekannten türkischen Sprachen, unter anderem auch zum Aserbaidschanischen, aufweist, ist erstmals von Vladimir Minorsky festgestellt worden (vgl. Minorsky 1911, S. 67).

\footnotetext{
${ }^{23}$ Ich habe mich bei der Auswahl der Gedichte von zwei Kriterien leiten lassen: 1. Es sollten mehrere Themen der Kälām-Dichtung eingebracht werden; 2. Es sollten mehrere Kälām-Dichter vorgestellt werden.
} 
Die in dieser Mundart des Türkischen überlieferten und in arabischer Schrift verfassten Texte sind in lateinischer Schrift transkribiert. Um die Besonderheiten der Aussprache dieser Mundart zu übertragen, wurden Zeichen nach den Richtlinien der Zeitschrift der Deutschen Morgenländischen Gesellschaft und nach den Richtlinien der Encyclopedia Iranica eingeführt.

Dabei bin ich davon ausgegangen, dass ein Phonem in unterschiedlichen Umgebungen unterschiedlich realisiert werden kann. Dieses betrifft in entscheidender Weise die Vokale. So wird [a] in der Position tat als offenes /a/ realisiert. Es wird im Anlaut und nach dem y im Türkischen bzw. im Aserbaidschanischen als kurzes /ä/ realisiert. Es wird aber in den arabischen, persischen und gūrānīschen Wörtern dieses Textes als langes $\overline{\mathrm{a}}=/ \overline{\mathrm{a}} /$ realisiert.

Das Phonem [u] wird in tot als /u/ realisiert. Es wird in $t^{\prime} \alpha t$, im Anlaut im Türkischen bzw. im Aserbaidschanischen als weiches / ̈̈/ und auch in den arabischen und persischen Wörtern als langes $/ \overline{\mathrm{u}} /$ realisiert.

Das Phonem [o] wird in tat als /o/ realisiert. Es wird in $t^{\prime} \alpha t$, y $\alpha t$ und im Anlaut im Türkischen bzw. im Aserbaidschanischen als /ö/ realisiert.

Das Phonem [i] wird in $t^{\prime} \alpha t$ und y $\alpha t$ als /i/ realisiert. Es wird nach harten Konsonanten, im Auslaut oder an der Morphemgrenze als spezifisch türkisches hinteres oder quantitativ reduziertes hinteres $/ \mathfrak{l} /$ realisiert. Es wird in den arabischen und persischen Worten dieser Mundart auch als langes $/ \overline{1} /$ realisiert.

Die weiteren Transkriptionszeichen für den Mittel-west-iranischen türkischen Dialekt sind:

- $\quad$ - wie arabisches $\varepsilon$ - [ ${ }^{\text {a ain] }] ~(g e p r e s s t e r ~ K n a r r l a u t ~ i n ~ d e r ~ S t i m m r i t z e) ~}$

, - wie arabisches $\varepsilon-$ diakritisches Zeichen Hamza: Stimmabsatz

H. h - wie arabisches $ح-[\hbar a:]$ (gepresstes h)

$\mathrm{H} \mathrm{h} \mathrm{-} \mathrm{wie} \mathrm{arabisch-persisches} \$$ - [ha:] (wie deutsches h)

$\mathrm{X} x$ - für türkisches/sowie arabisch-persisches $\dot{\tau}-$ (wie ch in ach, krach)

$\dot{\mathrm{G}} \dot{\mathrm{g}}$ - wie arabisch-persisches $\dot{\varepsilon}[$ rain] (stimmhaftes $\mathrm{x}$ )

Q q-wie arabisch-persisches ق [qa:f]

T t - wie arabisches b [tD:] (velarisiertes $\mathrm{t}$ )

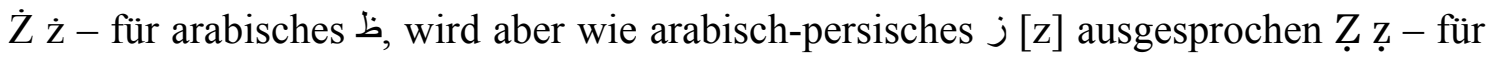
arabisches ض, wird aber wie arabisch-persisches $j[z]$ ausgesprochen $\underline{Z} \underline{z}-$ wie arabisch-persisches $\dot{j}$, wird $j[z]$ ausgesprochen 
$\breve{S} \breve{s}-$ wie arabisch-persisches ش [ [ji:n] (deutsches sch)

Ṣ ș - für arabisches ص, wird aber wie arabisch-persisches w [s] ausgesprochen

$\underline{\mathrm{S}}$ - wie arabisch-persisches $ث$, wie w [s] ausgesprochen

Y y - wie arabisch-persisches 1 , [j], [i]

$\check{Z} \check{z}$ - wie persisches $j[\check{z}]$ (zsch)

$\mathrm{B} \mathrm{b}-$ wie arabisch-persisches $ب[\mathrm{~b}]$

Čč - wie persisches $\underset{\mathrm{c}}{[\mathrm{t}]}]$ (tsch)

D d - wie arabisch-persisches $د[d]$

E e - wie arabisch-persisches, [e]

F f - wie arabisch-persisches $ف[\mathrm{f}]$

$\mathrm{Gg}$ - wie persisches $₹[\mathrm{~g}]$

$\hat{\mathrm{J}} \hat{\mathrm{j}}$ - wie arabisch-persisches $\mathrm{T}[\mathrm{dj}]$

$\mathrm{K} \mathrm{k}$ - wie arabisch-persisches $s[\mathrm{k}]$

L 1 - wie arabisch-persisches $J[1]$

$\mathrm{M} \mathrm{m}-$ wie arabisch-persisches $\mathrm{P}[\mathrm{m}]$

$\mathrm{N} \mathrm{n}$ - wie arabisch-persisches $ن[\mathrm{n}]$

$\mathrm{P} \mathrm{p}-$ wie persisches $\longleftarrow[\mathrm{p}]$

$\mathrm{R} \mathrm{r}$ - wie arabisch-persisches $\lrcorner[\mathrm{r}]$

S s - wie arabisch-persisches w [s]

$\mathrm{T} \mathrm{t}$ - wie arabisch-persisches $ت[\mathrm{t}]$

$\mathrm{V} \mathrm{v}$ - wie arabisch-persisches $9[\mathrm{w}]$

$\mathrm{Z} z$ - wie arabisch-persisches $j[\mathrm{z}]$

\section{- Die Übersetzung und die Deutung der Begriffe}

Viele religiöse und kulturelle Begriffe der Yārıstān sind der deutschen Sprache unbekannt. Die metaphorischen Denkmuster der orientalischen Dichter sind für die abendländische Kultur ebenfalls fremd. Außerdem gibt es in den Gedichten ein besonderes sprachliches Mittel für die Verheimlichung ${ }^{24}$ tatsächlicher Inhalte. Alle diese Tatsachen haben die Übersetzung erschwert und dazu geführt, dass nicht nur die Inhalte, sondern auch die sprachlichen Besonderheiten gleichermaßen berücksichtigt werden mussten.

\footnotetext{
${ }^{24}$ Verheimlichung (,Täqyya“) ist eines der Hauptprinzipien der Yārıstān.
} 
Das Ziel der vorliegenden Übersetzung war demnach, die Gedichte vom Inhalt her und nicht nach der Form ${ }^{25}$ zu übertragen.

Die Interpretation der religions- und kulturspezifischen Begriffe der heiligen Texte ist der wichtigste Arbeitsschritt, der zwar von der Übersetzung schwer abzugrenzen ist, weil die beiden tatsächlich gleichzeitig erfolgen, aber bei der Erklärung der sakralen Inhalte der Yārıstān-Religion (ihrer Weltanschauung, ihrer mystischen und sozialen Struktur und Vorschriften, ihrer Rituale und Bräuche) eine entscheidende Rolle spielt.

${ }^{25}$ Die Gedichte sind in der iranischen Gedichtform Ghasel verfasst worden. Da die Dichter die Kunst der Dichtung nicht unbedingt perfekt beherrschten (Qäländär war z. B. ein Schafhirte und konnte weder lesen noch schreiben), sind viele Ghasele in ihrer Formen unvollkommen. So blieb z. B. Quščioġlı, der ein professioneller Dichter war, fast immer im Rahmen der perfekten Ghasel-Form. Bei den anderen 23 Dichtern sieht man in ihren Werken wesentliche Abweichungen von der klassischen Ghasel-Form. 


\section{Geschichte, Verbreitung, Prinzipien der Yārıstān}

Der Kern der Lehre findet sich in Äsrār-e Yārī. Darin wird über die Weltschöpfung und den Weltschöpfer erzählt. Im Gänj̄inneh-e Yārī geht es um die Geschichte der Yārıstān. Im Āyīn-e Yārī wird über die Rituale und den Ritualkalender, über die Bräuche, die geistigen und sozialen Würden innerhalb der Yārıstān-Gemeinde erzählt.

Wegen der dogmatischen und konservativen Haltung der Pīrān und der Gläubigen kann man davon ausgehen, dass die Kälāmāt und die Reden von Generation zu Generation detailgetreu weitergegeben wurden und so bis heute ihre ursprüngliche Form weitestgehend beibehalten haben.

\section{Die Sagen und die Mythen über die Weltentstehung}

Da es keine schriftlichen Beweise über den Ursprung der Yārıstān gibt, gibt es auch keine Möglichkeit, diesen eindeutig festzustellen. Auch kann die Entwicklung dieser Religion nicht genau rekonstruiert werden.

Die Yārıstān-Gläubigen selbst behaupten aber, dass ihre Religion eine uralte Geschichte habe, da sie die Weltschöpfungsgeschichte in ihren Texten wiedergibt:

1. Von Anfang an war ich (Gott) schon da, aber ich war noch nicht zur Welt geworden.

2. Ich war noch nicht in Gestalt des Adams zum vollkommenen Menschen geworden.

3. Die ganze Welt war noch nichts als Wasser, als ich schon da war.

4. Ich verband die Seile vom Himmel mit der Erde noch nicht, als ich schon da war.

5. Als die Welt zustande kam, war ich schon da.

6. Es gab noch keinen Pavillon Gottes, ich war noch kein Heilmittel für die Welt.

7. Ich war das Licht, das Geheimnis in einer Öllampe,

8. Obwohl ich den Mond und die Sonne noch nicht geschaffen hatte.

9. Ich war in der Öllampe und wanderte durch die Dunkelheit.

(Kälām Nr. 103) 


\subsection{Die Weltentstehung in der Yārıstān-Darstellung}

Die Äsrār-e Yārī̄ („6 (Geheimnisse der Yārıstān”) von Säyyed Kāżem Nīknežād beginnt mit einer Erzählung über die Zeit vor der Weltschöpfung: vor vielen Millionen Jahren habe es nur eine Perle gegeben, die in einem Edelsteinrahmen eingerahmt war. Die Perle und ihr Rahmen standen auf einem Stein, der Väzāvär hieß. Diese Drei standen alle im Meer. Da es kein vollständiges türkisches Kälām darüber gibt, stützt sich Säyyed Kāżem Nīknežād in seiner Rede, so wie es auch die anderen Pīrān machen, auf die gūrānīschen ${ }^{27}$ Kälāmāt vom kurdischen Kälām-Dichter namens Šeyx Ämīr:

1. na qawi gawhar

2. padishâm na durr bê na qawi gawhar

3. na lawh na qalam na yâr na aghyâr

4. padishâm na durr bê durr na daryâbâr

5. na gâlây gâl bê na chirây chir bê

6. tâ chan waxt padishâm na dâna-i durr bê

7. chwârsad hazâr sâl na dilê durr bê

8. durr na tê daryâ parwarda-i sirr bê
1. Im Rahmen der Perle ...

2. Mein König (der Funke, die

Wahrheit) war in einer Perle und sie war von einem Rubin eingeschlossen.

3. Weder Himmel noch Erde, weder Schrifttafel noch Feder, weder Yār noch Fremde,

4. Mein König (der Funke der Wahrheit) war in der Perle, die Perle war im Meer (ein Meer, das durch den sintflutartigen Regen entstand).

5. Es gab weder Stimme noch Wörter, es gab weder Krach noch Lärm.

6. Eine Weile war mein König (der Funke der Wahrheit) in der Perle.

7. Er (der König) war vierhunderttausend Jahre in der Perle.

8. Die Perle in der Tiefe des Meeres War er Schöpfer der Geheimnisse.

\footnotetext{
${ }^{26}$ Äsrār-e Yārī enthält religiöse Reden und Erzählungen über die Entstehung der Welt, über die Menschenschöpfung, über die Geschichte, Vorschriften und Ritualen der Yārıstān.

${ }^{27}$ Die religiöse Sprache der Ähl-1 Häqq in Süd-Kurdistan heißt Gūrān̄i. Die Transkription des gūrān̄̄schen wurde nach S. Safizadeh (1997 b, S. 610-636) gemacht.
} 
Säyyed Kāżem Nīknežād spricht weiter über einen „Norūz“'28, der vierhunderttausend Jahre lang in einem grenzenlosen Meer war und die mystischen Geheimnisse erschuf. Nach dieser Zeit wurde er inspiriert, sich zu offenbaren und die Welt zu erleuchten bzw. die Welt zu erschaffen. In den Manuskripten von Nīknežād gibt es keine Erklärung zu den Wörtern „Norūz“ und „Inspiration“. Diese Begriffe finden sich aber bei G. Moradi in seinem Buch „Tarix-e Āhl-e Häqq Yārsān” mit einer völlig anderen Deutung. „Norūz“ sei ein Name von einem gūrān̄̄schen Kälām-Dichter - Derwisch Norūz Sūrān̄̄ (vgl. Moradi 1999, S. 235). Derwisch Norūz Sūrānī erzählt in einem seiner Kälāmāt über die Weltentstehung und sagt zum Schluss, dass er keine Macht über die Inhalte dieses Kälāms, das er nach der „Inspiration“ schrieb, habe (vgl. Moradi 1999, S. 237239).

Säyyed Kāżem Nīknežād hat den Text eines gūrānīschen Kälāms auf Türkisch zusammengefasst:

1. durr ičindän čixdı Šāhım dedı sırrım iżhār olson

2. yaradım yeridän göyı bir tuḥfa rūzıgār olson.

3. Pīr o țālıbloqun bänāsin qoydo Bınyāmīnun Šärțidän

4. dedı Rämzbāra Gälora gätor yer o göyda hā war olson

5. Xāvändıgār qoydo adun o yer o göy äyäsi

6. dedı ollam Sulțān Säḥāk Yārānlär dīdähdār olson
1. Mein König - die Wahrheit ${ }^{29}$ - kam aus dem Inneren einer Perle und sagte: „Mögen meine Geheimnisse offenbart werden".

2. Ich erschuf die Erde und den Himmel, möge es eine wundervolle Zeit geben.

3. (Mein König) erschuf die Grundlagen für die Meister und Schüler (Anhänger) nach dem Pakt (Šärț $\left.{ }^{30}\right)$ von Bınyāmīn.

4. (Mein König) sagte zu Rämzbār, sie soll eine Gabe bringen, damit dieses Ritual im Himmel und auf Erden verewigt wird.

5. Gott (Xāvändigār) nannte sich den Gebieter vom Himmel und Erde, 6. (Er) sagte: „Ich werde Sulțān Säḥāk, um für die Yārān ${ }^{31}$ sehbar zu werden““.

\footnotetext{
${ }^{28}$ Norūz heißt wörtlich „,neuer Tag““.

${ }^{29}$ „Wahrheit“ ist einer der zentralen Begriffe der Yārıstān; Sulțan Säḥāk ist die personifizierte Wahrheit.

30",Š̈rț" (arab.) -,,Bedingung“, aber im Yārıstān-Lexikon bedeutet das Wort „Pakt" (gemeint ist ein Vertrag zwischen Gott und Yārān. Bınyāmīn spielt dabei die Rolle des Vermittlers).

${ }^{31}$ Yārān - Pl. von Yār - sämtliche Yārıstān-Anhänger sowie Gott selbst und seine Helfer.
} 
In einem weiteren türkischen Kälām findet sich ein Hinweis auf die Weltschöpfung aus der Perle, und Sulțān Sähāa wird der Weltschöpfer genannt:

\section{Freunde der Wahrheit! Euer Herr ist Sulțān Säḥāk.}

2. Er löst die Probleme dessen, der ein Freund der Wahrheit ist.

3. Er erschuf aus der Perle die Erde und den Himmel,

4. Er ist König seit aller Ewigkeit.

(Kälām Nr. 20)

Sulțān Säḥāk (eine Verkörperung der Wahrheit bzw. Gottes) erschuf sofort nach dem eigenen Erscheinen den Yādigār ${ }^{32}$ (sein liebstes Geschöpf, dessen Wünsche ausnahmslos von der Wahrheit erfüllt werden sollen), gleichzeitig schuf er aus dem Stein Väzāvär weitere fünf Wesen mit den Namen:

1. Bınyāmīn (er wurde von der Wahrheit als Pīr eingesetzt, um die Rituale und Regeln festzulegen),

2. Dāvūd (er wurde zum Führer ernannt, um den „Vierzig Personen““33 den Weg zu zeigen. Er überwachte auch die Seelenwanderung),

3. Mūsī (zu seinem Aufgabenbereich gehört es, über die Seelenwanderung Buch zu führen),

4. Rämzbār (sie durfte sich bei der Wahrheit aufhalten),

5. Müșțäfā (er ist für den Austritt der Seele aus dem Körper verantwortlich).

Diese Fünf, Yādıgār und die Wahrheit ${ }^{34}$ - bilden die sog. „Sieben Wesen“335. Die Sieben Wesen haben eine Religion gegründet:

\footnotetext{
${ }^{32}$ Yādıgār ist einer der beliebtesten der „Sieben Wesen“ (s. u.) und erscheint in verschiedenen Formen, unter anderem als Syāwūš, ein Held der iranischen Mythologie, Imam Huseyn, der beliebteste Imam der Schiiten, Huseyn Mänșūr Ḥällā̂̀, eine wichtige Figur in der islamischen Mystik. Die historische Person Yādıgār wurde von den Feinden der Yārıstān getötet. Seine Grabstätte ist für die Yārıstān heilig.

${ }^{33}$ „Vierzig Personen“ ist die erste Yārıstān-Gruppe unter Dāvūds Führung.

${ }^{34}$ Einige der Pīrān meinen, dass eine weitere Person noch zu den Sieben Wesen (s. u.) hinzukommen wird (Sulțān Sähāk zählt nach deren Meinung nicht zu den Sieben). Dieses siebte Wesen hieß Šāh Ibrāhīm.

${ }^{35}$ Sieben Wesen - zwei verschiedene mythologische Gruppen von jeweils sieben Wesen: „Häftän“ (wörtlich pers. „Sieben Wesen“) und „Häftäwāna“ (wörtlich pers. „Sieben Mächte“). Es werden mit „Häftän“ vier Engel: 1. Binyāmīn, 2. Dāvūd, 3. Mūsī, 4. Rämzbār und drei weitere Figuren: 5. Yādıgār, 6.Müștäfā, 7. Šāh Ibrāhīm bezeichnet. Es werden mit „Häftäwāna“ sieben Verkörperungen (Emanationen) der Sieben Wesen bezeichnet: 1. Säyyed Mohämmäd, 2. Säyyed Bol-väfā, 3. Sulțān Bābūsīn, 4. Säyyed Šähāb-od-dīn, 5. Säyyed Ḥäbīb Šāh, 6. Säyyed Müșțäfā, 7. Mīr. Diese zwei Gruppen werden mit einem Oberbegriff „Äränlär" (wörtlich türk. „große Menschen“) bezeichnet.

Es gibt in der Yārıstān eine weitere Gruppe aus sieben Personen, die „Yārānqävāltāsī“ (gūrān.) heißt und sieben sagenhaften Personen bezeichnet, die sich wegen des Mordes eines Yārs bei Sulțān Säḥāk beklagen wollten und unterwegs erfroren und starben. Sie wurden vom Sulțān Sähāk unter einer Schale aus Schneeflocken wieder belebt. Ihre Namen sind: 1. Qolī, 2. Šähāb-od-dīn, 3. Šākäh, 4. Šāh Näżär, 5. 'İsī, 6. Šāh Morād, 7. Pīr-e Dilāvär.
} 
1. Wo ist der Schöpfer der Welt und der Existenz?

2. Ihr, Freunde der Wahrheit, ruft ihr diesen, der keinen Platz besetzt.

3. Er schuf während der Gestaltung von $\mathrm{Ya}^{-36}$ den Himmel und die Erde.

4. Seine weiteren Schöpfungen heißen Dāvūd, Bınyāmīn und Pīr Mūsī.

5. In diesem Moment schuf er die Sieben Wesen.

6. Rämzbār brachte eine Decke und Brot.

7. Sie verteilte das Brot an den Führer und den Obersten.

8. Das Gebet wurde gesprochen, und die Erfüllung fand statt.

(Kälām Nr. 289)

Die sieben mystischen Wesen sieht man in den mit der Yārıstān benachbarten Religionen des Zarathustrismus und des Yezidismus ${ }^{37}$. So sind die sieben Herren des Zarathustrismus: „He, first, produced the seven fundamental Beneficent-Immortals, them the others; the seventh, Ôhrmazd Himself; of the material creations, created in the spirit, the first are six; He Himself was the seventh (...)“ (vgl. Anklesaria 1956, S. 17). Im Yezidismus sieht man ebenso sieben Heptad, „consists of Sheykh Adi, Melek Tawus, and these five figures“ (vgl. Kreyenbroek 1995, S. 38) bzw. sieben Erzengel (vgl. Omarhali 2005, S. 33, 43, 56, 92f.).

Der Beginn der Yārıstān-Geschichte ist mit dem Namen von Sulțān Sähāk verbunden:

3. Dieser (Sulțān Sähāa) kam auf die Welt in tausend und einer Gestalt.

4. Seine (letzte) Gestalt (als Sulțān Säḥāk), die bei Pīrdävär erschien, lieben sie.

(Kälām Nr. 60)

Die Kälāmāt-1 torkī verrät die weiteren Namen Sulțāns: Sulțān-1 Sāḥıbäräm, Xāvändıgār, „König“, „König der Welt", „König des Anfangs und des Endes“, „Großherzigkeit“, „Großmut" und andere und betrachtet den Mann als die Verkörperung Gottes.

\footnotetext{
${ }^{36} Y \bar{a}$ ist die zweite Ära der Weltschöpfung.

${ }^{37}$ Der Yezidismus ist eine Religion in den Ländern Irak, Armenien, Georgien, Syrien, Türkei. Diese Religionsgemeinschaft hat Philip Kreyenbroek in seinem Buch ,Yezidism - its background, observances and textual tradition" erforscht (1995).
} 
5. Das Licht, die Sonne und der Mond, die Erde und der Himmel sind alle sein (Sulțān Säḥāks) Hof.

6. Seines Hofes Tor ist offen für alle, die sich nach ihm sehnen. Es ist eine gesegnete Nacht! Es ist eine gesegnete Nacht!

7. Mein Herr (Sulțān Säḥāk) ist einzigartig, er ist überall anwesend.

(Kälām Nr. 6)

3. Ich verlange von dir, du König der Welt (Sulțān Säḥāk),

Besitzer der Erde und des Himmels,

4. Mir zu verzeihen wegen des Paktes Bınyāmīns. Hilf mir!

Ich schreie um Hilfe.

(Kälām Nr. 17)

Nach dem Kälāmāt-1 torkī ist er der Weltschöpfer. Dank ihm hat der Yārıstān eigene Gesetze, Regeln und Prinzipien entwickelt und festgelegt.

Das erste Geschöpf von Sulțān Säḥāk heißt Yādıgār. Yādıgār bedeutet im Persischen „Erinnerung“. Unter „Erinnerung“" versteht man eine Erinnerung an Gott bzw. an Sulțān Säḥāk. Kāżem Nīknežād stellt in Äsrār-e Yārī den Akt der Schöpfung Yādıgārs so dar: Sulțān Sähāak gab Pīr Ismā’yl Kūhlānī einen Stock aus Granatapfelholz und befahl, ihn einzupflanzen. Aus diesem Stock wuchs ein Baum, und ein paar Jahre später brachte er zahlreiche Früchte. Sulțān Sähāk und seine Anhänger haben einen der Granatäpfel in das Jäm-Xāna gebracht, ihn gesegnet, aufgeteilt und gegessen. Am nächsten Tag in der Frühe hat ein Mädchen Namens Sārī, die Tochter eines Yārıstān-Gläubigen, den Boden im Jäm gefegt. Sie fand auf dem Boden einen herunter gefallenen Granatapfelkern. Weil der Kern heilig war, durfte sie ihn nicht wegwerfen. Sie verschluckte ihn. Als sie ihn verschlucken wollte, beleuchtete den Kern ein Sonnenstrahl. Das kam ihr wie ein Zeichen Gottes vor. Etwas später erfuhr sie, dass sie schwanger ist. Sie wurde von ihren Mitmenschen als Sünderin angeklagt. Ihre Eltern und ihre Verwandten schämten sich ihretwegen. Viele Menschen waren dabei, als ihr Kind auf die Welt kam. Sulțān Säḥāk wollte mit seinen Helfern den Menschen Heiligkeit Yādıārs beweisen. Dafür haben sie ihn einer Feuerprobe unterworfen: er wurde in eine glühende Backgrube geschoben. Er musste in dieser Backgrube aushalten. Nach der Probe war er immer noch am Leben und lächelte alle an. 


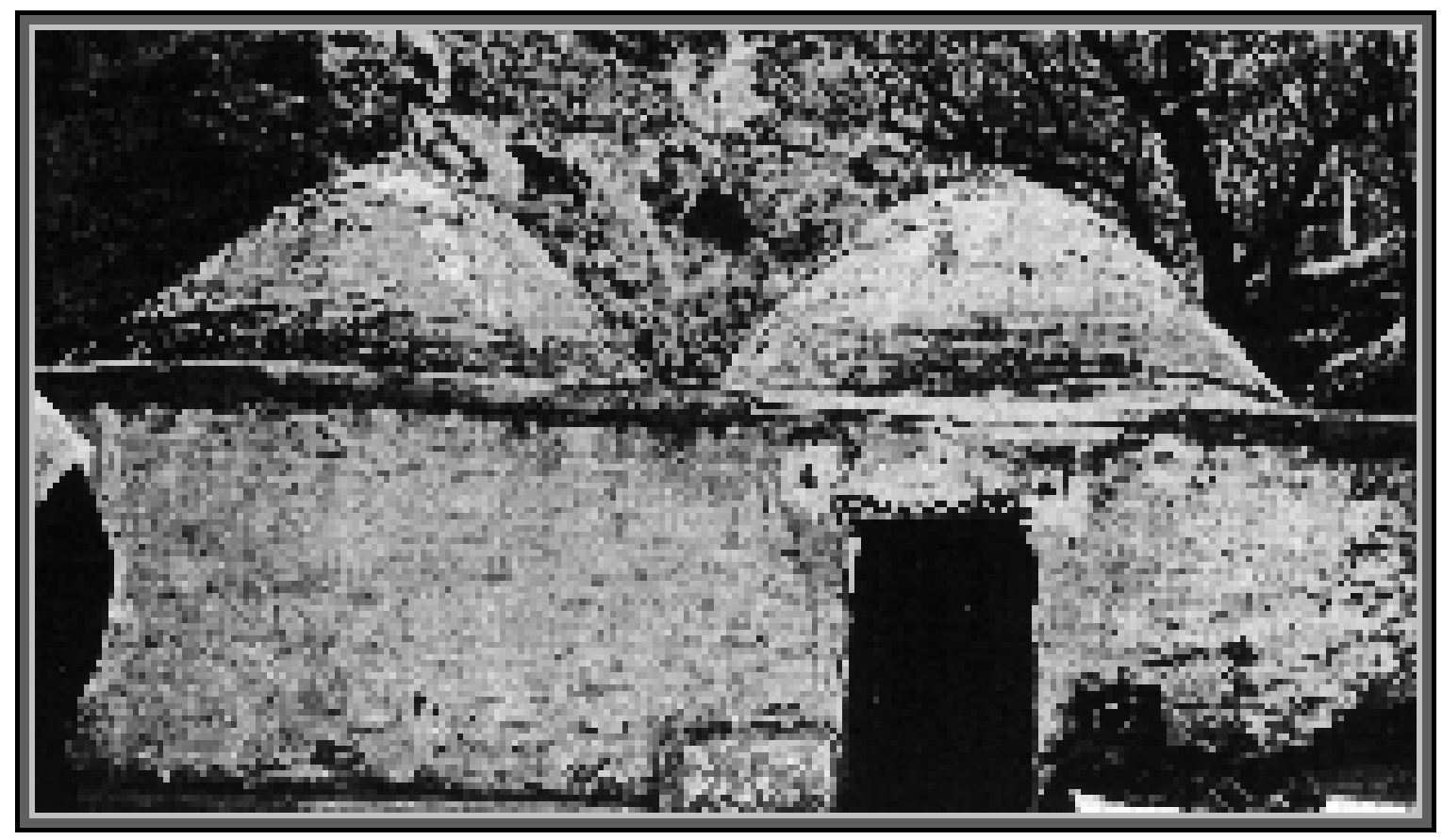

Das Mausoleum vom Sultān Sähāk in Pärdīvär

(ein Foto aus der Handschrift „Gänĵ̄neh-e Zärnegār“ von Säyyed Kāżem Nīknežād). 
An dieser Stelle hat Sulțān Säḥ̄āk seinen Funken - die Seele - dem Yādıgār übergeben. Der Bericht über dieses Geschehen wird in den Reden der Äsrār-e Yārī dem Pīr Mūsī zugeschrieben. Die Geburt Yādıgārs wird als eine keusche Empfängnis dargestellt:

3. Ich war ein trockener Holzstock. Mein Herr steckte mich in die Erde. Ich wuchs als ein Baum auf.

4. Jetzt bin ich die reife Frucht, die voll von Perlen ist, und komme ins Ĵ̈äm.

(Kälām Nr. 129)

Bābā Yādıgār bzw. Pīr Yādıgār (Äyvät Häšār, Äḥmäd) zählt zu den beliebtesten Personen der Yārıstān. Er ist eine Inkarnation des mythologischen Helden Syāwūš. In seiner Inkarnation als Syāwūš hat auch er eine Feuerprobe bestanden, um seine Unschuld zu beweisen (vgl. Firdousi 1373/1994, Band 3, S. 33-36). Bābā Yādigār - als ein realer Mensch - lebte nach Angaben von Nīknežād in der ersten Hälfte des 10. (16.) Jahrhunderts. In der Handschrift „Gänj̄inneh-e Zärnegārr“ von Nīknežād findet sich die Kopie einer Schenkungsurkunde. Sie berichtet von einem Geschenk von fünf Sechstel eines Dorfes namens Qäl'ä-Šāhī („Königliche Burg“) mit zugehörigen Feldern, Wäldern, Wasserquellen und einer Mühle, das im Jahre 933 (1527) von dem Grafen Qomām-od-dīn-e Kurd aus der Provinz Kermānshāh an Bābā Yādıgār gemacht wurde.

Gott selbst hat Bābā Yādigār dazu bestimmt, die Gläubigen zu taufen, und hat seine Hand in eine Wasserquelle verwandelt, die nie verdirbt, sondern immer sauber und frisch bleiben sollte. Diese Quelle heißt Gäslān und befindet sich im Westen des Iran, in der Provinz Kermānshāh, in der Nähe der Stadt Särpol-e Zähāb. Sie liefert den Pilgern immer noch trinkbares Wasser. Die Quelle sprudelt in einer Entfernung von ca. 30 Metern vom Mausoleum Bābā Yādıgārs, das auf dem Bergrücken Dālāhū steht.

Die historische Person Yādıgār wurde von Feinden der Yārıstān getötet. Seine Grabstätte ist für die Yārıstān heilig. Bābā Yādıgār ist auch dafür zuständig, mit dem Klang seiner Sūr (Posaune) die Verstorbenen am letzten Tag der Welt oder die Lebenden zum Treffen mit Gott zusammenzurufen ${ }^{38}$ :

15. Äyvät Häšār blies in sein Horn.

16. Dadurch wurde die Xānıdān des Dieners gewarnt.

(Kälām Nr. 25)

\footnotetext{
${ }^{38}$ Eine der Inkarnationen Bābā Yādıgārs ist der Erzengel Esrāfīl.
} 


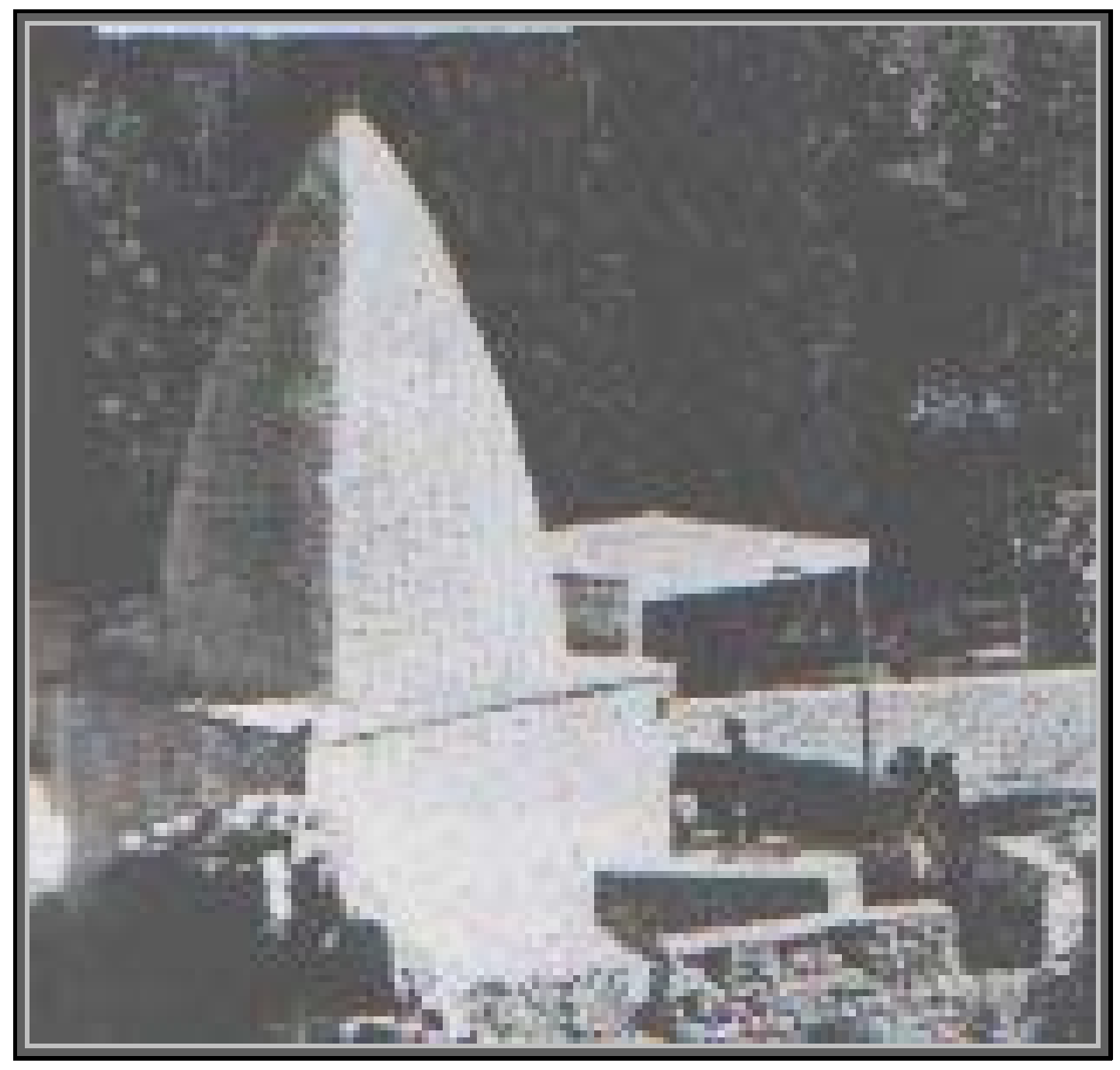

Bābā Yādıgārs Mausoleum, das auf dem Bergrücken Dālāhū steht (ein Foto aus der Handschrift „Gänj̄inneh-e Zärnegār““ von Säyyed Kāżem Nīknežād). 


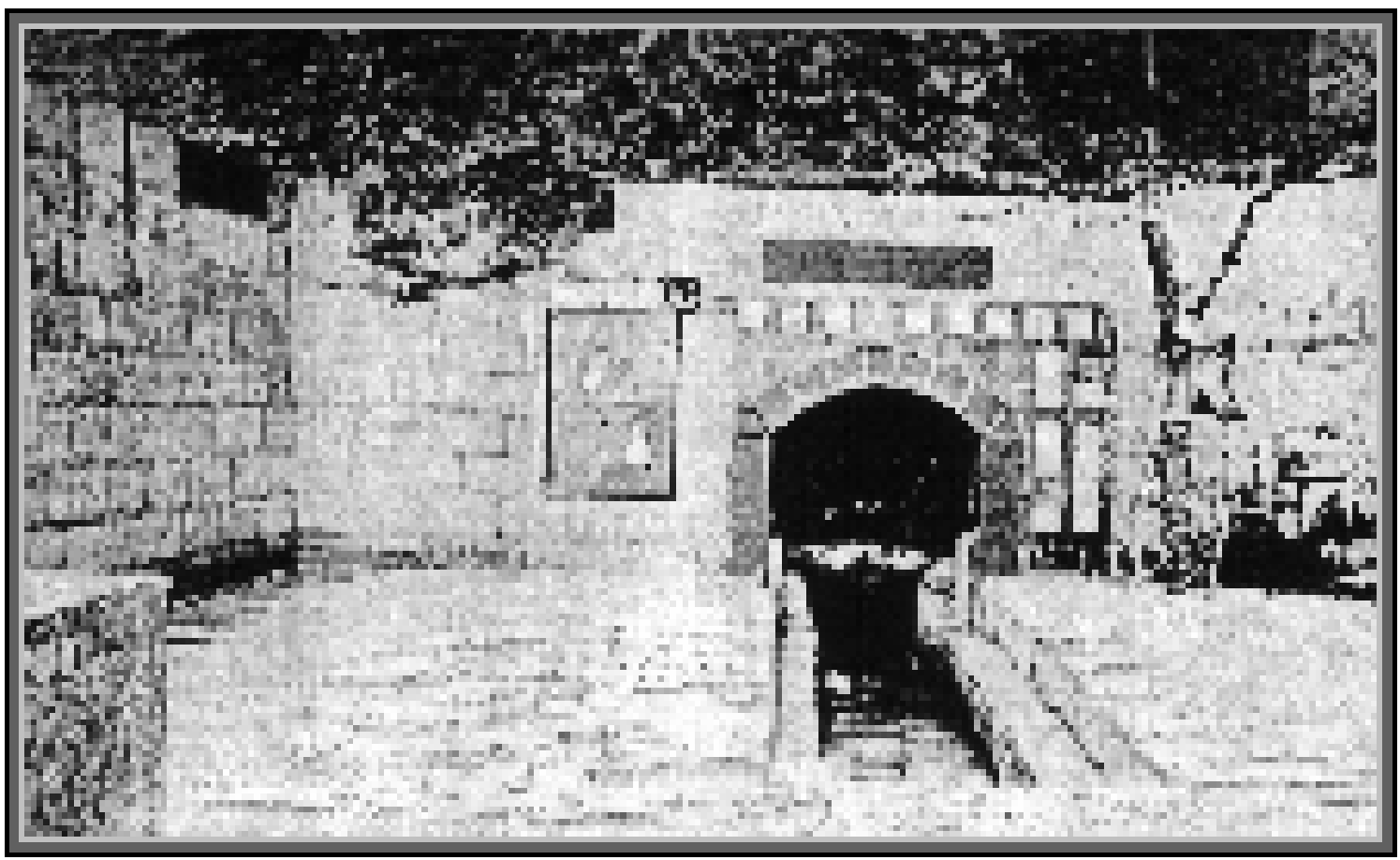

Die Gäslān-Quelle

(ein Foto aus der Handschrift „Gänĵ̄neh-e Zärnegār“ von Säyyed Kāżem Nīknežād). 
Sowohl die Kälāmāt-1 torkī, als auch die Erzählungen in der Äsrār-e Yārī sagen, dass Yādıgār in seinen anderen Verkörperungen immer eine bedeutende Figur war: z. B. als Syāwūšs, der Held der iranischen Mythologie, oder als Imam Huseyn, der beliebteste Imam der Schiiten, oder als Huseyn Mänșūr Hällâĵ (eine wichtige Figur des islamischen Mystizismus) und als Ismāēil der Prophet:

11. Wie Ismā ${ }^{\mathfrak{i}}$ l kapituliere ich auf dem Wege Gottes.

(Kälām Nr. 8)

Yādıgār hat aus einem Teil von sich ein Opfertier ${ }^{39}$ mit dem Namen „Kälzärdä““ (,gelber Büffel Männchen oder Ziegenbock)““ erschaffen und hat ihn zum Opfer bereitet ${ }^{40}$ :

12. Käme bloß der hübsche Schafbock statt mir als Opfer, oh Gott!

(Kälām Nr. 8)

Nach dem Messergebet und dem Schlachten des Opfertiers durch Bınyāmīn und dessen Zubereitung und Verteilung durch Yādıgār mit „Takbīrr ${ }^{641}$ von Binyāmīn wurde das Mahl gegessen. So wurden der Anfang und die Grundlage der religiösen Prinzipien der Yārıstān von Yādıgār geschaffen.

Die Gründung der Religion verbinden die Yārıstān-Gläubigen vor allem mit dem Namen von Bınyāmīn, dem Führer der Sieben Wesen bzw. dem ersten Pīr der Yārıstān. P̄̄r Bınyāmīn gilt als der Herr von „Šärț“ und „Iqrār‘‘42 und ist für die Ausübung sämtlicher Rituale in der Yārıstān zuständig. Das wichtigste Ritual, wofür er verantwortlich ist, ist „Särsıpāri““ („die Unterwerfung“ bzw. die Initiation). Für die Ausübung dessen brauchte er „Jovz“. Ein Jovz (eine Muskatnuss) ist aus dem Schweißtropfen von Bınyāmīns Stirn entstanden. Die Deutung dieses Ereignisses von Säyyed Kāżem Nīknežād besagt, dass alles, was je benötigt wird, durch die Sieben Wesen erschaffen wurde und demnach keine fremden Elemente in der Weltanschauung dieser Gemeinde eine Rolle spielten.

Da kein türkisches Kälām über dieses Ereignis berichtet, beruft sich Säyyed Kāżem Nīknežād wieder auf ein gūrānīsches Kälām aus der Äsrār-e Yārī:

\footnotetext{
${ }^{39}$ Unter einem „Opfertier“ wird meistens ein Stier verstanden.

${ }^{40}$ Hier sieht man die Ähnlichkeit zwischen dem Opferritual im Mithraismus und dem Opferritual in der Yārıstān. Ebenso besteht eine Ähnlichkeit bei der Seelenwanderung unter Menschen und Tieren in den beiden Religionen.

${ }^{41}$ „Takbīr“ sind Sätze, die zu verschiedenen Anlässen durch den Diener im Jäm-Xāna ausgesprochen werden. „Takbīr“" wird durch den Pīr mit einem abschließenden Segnen beendet. Die Yārıstān bestätigen dies mit „Amin“ (,Amen“).

${ }^{42}$ Iqrār heißt wörtlich „Bekenntnis“ und bedeutet im Yārıstān-Lexikon dasselbe wie Šärṭ.
} 
1. jovzi girtin zi ¿araq-i binyâm

2. âwirdan aw jam chany saranjam

3. shart da wa binyâm haq wa ramzbâr

4. daftar wa mûsâ nâz wa yâdigâr

5. rahbar wa dâûd chilâna wa shûn

6. pirchyn-i almâs haq wa dûnâydûn

7. nyâzish zâtin chwâr kasa dar ham

8. dâûd dalyl bê sipirdish wa jam
1. Aus einem Schweißtropfen von Bınyāmīns Stirn entstand ein Jovz.

2. Nach den Vorschriften des SaranjamGesetzes brachte man ihn zum Jam.

3. Jeder hat eine Aufgabe bekommen: den Pakt und die Verpflichtung für Bınyāmīn. Eine Erlaubnis für Rämzbār, ohne Anmeldung beim Sulțān Säḥāk zu erscheinen.

4. Ein Heft zum Schreiben für Mūsī, ein Recht, sich verwöhnen zu lassen, hat Yādıgār erhalten.

5. Die Oberführung - für Dāvūd - um den Weg für die Vierzig Personen zu beleuchten.

6. Diese letzte Aufgabe war scharf und schneidend wie ein Diamant. Seine weitere Aufgabe war, die Seelenwanderung zu beaufsichtigen.

7. Ihr (der vier Engel) Gelöbnis war, das Existieren Gottes zu bewahren,

8. Und Dāvūd wurde zum Führer von Särsıpārī ernannt.

Pīr Bınyāmīn ist auch als ein realer Mensch, Xıẓr-e Šāhūyi, der iranischen Geschichte bekannt. Sein Mausoleum befindet sich in der Stadt Kerend, in der Provinz Kermānshāh, im Westiran (vgl. Dehkhoda 1968, Band 39, S. 479). Wir haben jedoch keine genauen Geburts- und Sterbedaten von Binyāmīn.

Bei der Betrachtung der Figur vom Pīr Bınyāmīn stellt man gewisse Ähnlichkeiten mit dem Mithra, dem indo-iranischen Gott in den Vorzarathustra-Zeiten, fest. Darauf hat schon früher P. G. Kreyenbroek in seinem Artikel „Mithra and Ahreman. Binyamin and Malak Tawūs” hingewiesen: „The purpose of the present paper is to show that the essentials of the pre-Zoroastrian cosmogony, with an admixture of Zoroastrian elements similar to that of Mithraism, can still be found in the mythology of two modern sects, the Yesidis and the Ähl-1 Häqq, both of which may have originated among speakers of 
Western Iranian languages“ (Kreyenbroek 1992, S. 58). Bınyāmīn wird in der YārıstānDoktrin genauso wie Mithra im Zarathustrismus (vgl. Boyce 1975, S. 22-84) als der wichtigster Gotteshelfer anerkannt. Die beiden sind für den Pakt, die Verpflichtung und die Treue der Gläubigen wie die Ordnung innerhalb ihrer Gemeinden, wie auch für die Ausübung der Opfer-Rituale in ihren Religionen verantwortlich. Letztendlich sind die beiden die obersten Richter im Gerichtshof Gottes. Die Wiederkehr der beiden wird von den Gläubigen beider Religionen erwartet.

An zweiter Stelle in der Sieben-Wesen-Hierarchie steht Dāvūd, der Führer der YārıstānGemeinde. Seine erste Aufgabe war es, das Versammlungshaus für die YārıstānAngehörigen - das Jäm-Xāna - einzurichten.

Ein Jäm stellt einen großen Saal dar, der sich gewöhnlich in dem Untergeschoss eines beliebigen Gebäudes befindet. Eine Bedingung muss trotzdem erfüllt werden: der Pīr dieser Xānıdān, dem das Jäm zu Verfügung steht, muss in diesem Gebäude leben. Solcher ${ }^{43}$ Pīr heißt auch Särjäm („Der Kopf der Versammlung“).

Die erste Einheit der Angehörigen bestand aus 40 Menschen, die in der Kälāmāt-1 torkī als „Vierzig Personen“ bezeichnet sind. Diese 40 gehörten zu einem Jäm unter der Führung von Dāvūd. Unter diesen 40 waren auch Muhammad der Prophet und sein Cousín `Älī (der erste schiitische Imam). Es finden sich Kälāmāt in der Kälāmāt-1 torkī, die Muhammad und ‘älī als Anhänger der Yārıstān erwähnen:

7. Ich sagte, dass mein Pīr 'Ālī, der einer der Vierzig Personen ist, dass der der Freund Gottes unter den 40 ist.

(Kälām Nr. 56)

11. Als Muhammad wieder herunter kam, hörte er eine Stimme.

12. Er sah, dass das Geheimnis Gottes schon erzählt wurde.

13. Er sagte, dass er ein Diener der Elenden sei, dann wurde ihm die Tür geöffnet.

14. Er sah, dass der König der Vierzig Personen dort saß.

15. Diese Vierzig Personen fragten Muhammad, was er sah?

(Kälām Nr. 297)

Die weitere Aufgabe Dāvūds ist es, die Seelenwanderung zu überwachen. Die Seelenwanderung (Inkarnation) mit dem Ziel der Wandlung von niedrigen Formen der

\footnotetext{
${ }^{43}$ Es gibt Pīrān, die keine Särjäm sind und keine Rituale durchführen. Obwohl sie als Pīr bestätigt sind und ein Jäm-Xāna gründen dürfen, lehnen sie (aus verschiedenen Gründen) dieses ab.
} 
Lebewesen bis $\mathrm{zu}$ einem reinen Menschen gehört $\mathrm{zu}$ den Hauptmerkmalen der Weltanschauung der Yārıstān.

7. Wir haben uns gequält, wir haben auf diesem Wege (des Lebens in der Yārıstān-Gemeinde) unser Blut geschluckt.

8. Nennt ihr uns nicht gestorben! Es ist eine Umgestaltung. (Kälām Nr. 32)

3. Die Welten sind vergangen. Wir werden auch vergehen.

4. Nennt ihr uns nicht ,gestorbene“! Es ist eine Umgestaltung für uns. (Kälām Nr. 36)

Obwohl sich alle Yārıstān-Xānıdān in ihrer ethnischen Identität (aserbaidschanisch, persisch, kurdisch usw.) und in ihren Staatsangehörigkeiten (türkisch, iranisch, irakisch usw.) stark unterscheiden, sehen sie sich ausnahmslos als Yārān im Gegensatz zu allen anderen „Żahārāt“ („exoterischen“) Menschen oder „Tadjiken“ an. Die Yārān sind lediglich die Gläubigen, für die der Sinn des Lebens bzw. die absolute Wahrheit durch die Seelenwanderung erreichbar ist.

Die Wahrheit ist der zentrale Begriff für die Yārıstān-Weltanschauung. Die Wahrheit als der Ausdruck des Guten (siehe z.B. Kälām Nr. 19, 51, 54, 56) steht im Gegensatz zum Zweifeln, dem Bösen (siehe z.B. Kälām Nr. 23).

Das Gute oder die Wahrheit ist der Sulțān Sähạak, der Schöpfer der Welt, und seine sieben Helfer bzw. Sieben Wesen, die in der Kälāmāt auch „mit der Wahrheit Geeinte“ genannt werden.

1. Sehet aufrichtig Xāvändıgār (Sulțān Säḥāk) als die Wahrheit an, weil nur die Wahrheit-Liebenden so beobachten.

2. Er erschuf die Sieben Wesen mit Freude. Die Sieben Wesen lieben alle.

3. Xāvändıgār ist der Gipfel aller der Geheimnisse.

4. Diese Sieben Wesen werden von der Wahrheit geliebt, sie sind ebenso das Heilmittel für eure Schmerzen.

5. Adlige Diener (die Sieben Wesen) sitzen. Und die Wahrheit spricht sie an. 
6. Erkennt, dass sie (die Sieben Wesen) Dīvān ${ }^{44}$ sind.

7. Die fließenden Bäche, die fließenden Flüsse und die Brunnen,

8. Sie sind Tröpfchen für Tröpfchen zusammen gekommen, so wurden sie zum ${ }^{\circ} \mathrm{Oman}^{45}$-See.

9. Komm du näher, entferne dich nicht, Quščığ $11^{46}$,

10. Wenn du etwas über Gott wissen willst, sollst du sie (die Sieben Wesen) kennen lernen.

(Kälām Nr. 18)

Jeder Yārıstān-Angehörige strebt danach, die Wahrheit zu erreichen und mit ihr eins zu werden. Und auf diesem Wege darf er kein Zweifeln haben:

12. Ich sah, wie der sündhafte Boden verwüstet wurde.

13. Ich sah, wie der Zweifelnde zum Heimatlosen wurde.

14. Du würdest glauben, dass er ein toter Esel ist.

(Kälām Nr. 23)

Da Dāvūds Aufgabe die Überwachung der Seelenwanderung ist, trennt er die Gläubigen von den Ungläubigen und lässt die Seelen der Gläubigen wandern. So sterben die Yārıstān-Angehörigen nie.

Dāvūd ist außerdem ein mächtiger Krieger, der die Gemeinde schützt, so Säyyed Kāżem Nīknežād in der Äsrār-e Yārī. Als Sulțān Säḥāk in Begleitung von Drei Wesen von der kurdischen Stadt Šāräzūr nach Pīrdävär im Iran umzog, wurde er von einer großen Armee belagert. Dāvūd hat diese Armee niedergeschlagen und Sulțān Säḥāk gerettet:

9. Mittagshelligkeit herrscht in Bäyābäst, weil ein

10. Reiter (Dāvūd) von Pīrdävär auf seinem Pferd sitzt.

(Kälām Nr. 25)

9. Ein beispielloser Reiter (Dāvūd) kommt von Pīrdävär her.

(Kälām Nr. 34)

Eine ausführliche Erzählung über dieses Ereignis findet sich allerdings nur in der gūrānīschen Kälāmāt, die in der Äsrār-e Yārī von Säyyed Kāżem Nīknežād zitiert

\footnotetext{
${ }^{44}$ Dīvān ist der Gerichtshof Gottes oder die absolute Gerechtigkeit.

45 'Omān heißt ein absolutes Meer.

${ }^{46}$ Der Name des Dichters dieses Kälāms.
} 
wurde. Das Geschehen ist in Form eines Dialoges zwischen den vier Sprechern dargestellt:

Dâûd maramo:

1. âmânin âmân xwâjây- i gholâmân

2. âmâ lashkarî bê sar o sâmân

3. binyâmîn wastawar-i shartanî bigîrish dâmân

4. niyûmân wa das xwâjây-i gholâmân

Pîr mûsî maramo:

5. na xamây-i xama kishânû kowân na xamây-i xama

6. gîr-i nâlinâ bismâr o somâ

7. bîma larza na xâter xwâjâm nînâ majamâ

Binyâmîn maramo:

8. yâ shâh înrâ mâ kardîm

9. gunâ kas nakard gunâh mâ kardîm

Sultân maramo:

10. pîr-i balâ kish gar mard-i liqâîy byâ balâ

11. byâ balâ kish mard-i bê balâ mard-i liqâ nîst

Binyâmîn maramo:

12. yâ shâh dar miyân-i sad balâ bâshîm bâ hamsohbatân-i shâh ânjâ to bâshî balâ nîst
Dāvūd sagte:

1.,Hilfe, Hilfe, Herr von Knechten!

2. Eine Armee kommt, die keinen Anfang und kein Ende hat.

3. Bınyāmīn, du bist der Herr vom Pakt und den Regeln in der Yārıstān, bete Gott an um seine Hilfe,

4. dass Gott uns nicht verlässt.

Pīr Mūsī sagte:

5. Wir dürfen uns keine Sorgen machen. Die Täler und Gebirge sind traurig und betrübt.

6. Wir sind zwischen dem Hammer und dem Klotz.

7. Wir haben nicht Angst um uns, sondern um unseren Herrn, der sich unter uns befindet.

Binyāmīn sagte:

8. Du, unser König, wir haben dieses getan.

9. Keiner ist schuldig außer uns“.

Sulțān Säḥāk sagte:

10. „Wenn ein Führer Gott begegnen will, muss er bereit sein, von einer Katastrophe betroffen zu werden.

11. Ein Mann, der keine Katastrophe durchlebt hat, ist kein Gottesmensch“.

Binyāmīn sagte:

12.,,Unser König, mögen wir auch von Hunderten von Katastrophen bedroht werden, aber wenn du und deine Helfer 
Sultân maramo:

13. dâûd wa das-i jam wa ishâri-i haqî mishtî xâk wargîr bûzish wa rûy

14. das byir aw zhîr-i qâlîchi do mishtî... yûy o bûrân xârijî domakî

15. shâh farmâ daw wa bîra- $i$ jalâ bûzish wa chîchak wa ¿zm-i qazâ

16. wa âryây-i shâh dâûd warîzâ nimâ wa jilâyû mistafâ

17. sar frûz âwird gholâm-i tîltâr lowâ piy chîchak tâyifi- i kofâr

18. sih shabâni rozh qizâyi chîchak kird tâqî zîhayât zhîshân bar nakard dabei sind, dann gibt es keine

Katastrophe".

Erzähler ${ }^{47}$ :

Sulțān Sähāāk hat eine Höhle im

Bergrücken gezeigt, worin alle

Dreier ${ }^{48}$ und Sulțān selbst sich

verbergen könnten.

Sulțān hat einer Spinne befohlen, den

Eingang mit einem Spinnennetz zu

versperren“.

Sulțān Sähāāk sagte:

13.,„Du Dāvūd, so wie die Versammlung im Jäm entschieden hat und unter meinem Befehl, nimm eine Hand voll Lehm und wirf sie auf die Angreifer hin,

14. Um diese nutzlosen fremden Eroberer zu vernichten.

15. Der König befahl, du Dāvūd, nimm und nutz deine Waffe gegen diese Čičäk ${ }^{49}$-Armee, um sie zu vernichten“.

16. Dāvūd war aufgestanden und bereitete die Waffe, die ein Element von Müștäfā (einem der Sieben Wesen) enthielt, vor.

17. Dāvūd verbeugte sich vor dem Sultạn Säḥ̄ak und begab sich in die Schlacht.

18. Diese Schlacht dauerte drei Tage und drei Nächte bis zum letzten Menschen der feindlichen Armee.

\footnotetext{
${ }^{47}$ Erzähler ist Säyyed Kāżem Nīknežād, der das Kälām in seiner Rede kommentiert.

${ }^{48}$ Binyāmīn, Dāvūd und Mūsī.

${ }^{49}$ Čičäk und Mandschuren sind türkische islamische Völker aus der Zentralasien, die religiöse Kriege gegen Yārıstān geführt haben (siehe z. B. Kälām Nr. 31).
} 
Erzähler:

Der Staub und der Nebel, die vom

Kampf aufgewirbelt waren und den

Himmel bedeckten, waren nachher

weg.

Seit diesem Ereignis müssen die

Yārıstān-Gläubigen an diesen drei

Tagen fasten und fünf Nächte lang eine jährliche Jubiläumszeremonie durchführen. Die fünfte Nacht ist für ein Gottesfest „Dāvāt-1 Šāhī“.

Seitdem die Dreier sich in der

Höhle verborgen hatten, ist es befohlen worden, an demselben Tag zur

Verehrung dieses Ereignisses und aus

Liebe zu des Sulțāns Begleitern -

Bınyāmīn, Dāvūd und Pīr Mūsī - zu

fasten und das Gottesfest „Dāvāt-1

Šāhī" zu veranstalten.

Unter den Yārıstān-Angehörigen gibt es einen Spruch über Dāvūd, der das blaue Pferd reitet. Dieses Pferd ist nichts anderes als der Himmel. Ein anderer Spruch besagt, dass Dāvūd den Stier, der die Erdkugel auf seinen Hörnern trägt, reitet. Er wird auch als Dāvūd-1 Dīvān, d. h. der Herr des Gerichtshofs Gottes, genannt. So wird seine sagenhafte Natur schon in der Sprache festgehalten. Seine Heldentaten überschreiten die Grenzen der alltäglichen Vernunft: er kämpft an der Seite des Guten allein und besiegt sogar, so die Äsrār-e Yārī, die ganze Armee.

Die iranische Mythologie kennt einen anderen Helden, der in seinem sagenhaften Heldenmut dem Dāvūd ähnlich ist. Er heißt Bährām bzw. Wahram bzw. Verethraghna (vgl. Kreyenbroek 1992, S. 70). Er nimmt zehn unterschiedliche Gestalten an: 1) einen mächtigen Wind, 2) einen männlichen Ochsen mit den gelben Ohren und goldenen Hörnern, 3) einen Schimmel mit goldenem Geschirr, 4) ein Lastträgerkamel mit scharfen Zähnen, 5) ein mächtiges Wildschwein mit scharfen Zähnen, 6) einen 15jährigen Mann, 7) einen schnellen Vogel, 8) einen Wildbock, 9) einen Kampfziegenbock, 10) einen Held mit goldenem Schwert (vgl. Hinnels 1975, S. 41). 
Bährām kämpft gegen einen Dämon, der das Hungerjahr mitbringt, und gegen die Hexen, die Kinder töten (vgl. Hinnels 1975, S. 38).

Die Yārıstān glauben, dass Dāvūd in der Nähe der Stadt Särpol-e zähāb in der Provinz Kermānshāh starb. Seine Grabstätte liegt in einem Tal, das Käl-e Dāvūd heißt.

Die dritte Figur in der Sieben-Wesen-Einheit ist Pīr Mūsī, der Schriftsteller, der Herr der Schreibfeder:

6. Des Griffels (der Feder) von Pīr Mūsī und des zornigen Müșțäfās wegen begnadige mich.

(Kälām Nr. 1)

4. Die Feder von Pīr Mūsī begann zu schreiben.

(Kälām Nr. 25)

16. Der Schriftführer Pīr Mūsī ist auch unser Buchführer.

(Kälām Nr. 40)

Pīr Mūsī hat in der Yārıstān den Ruf eines Weisen; er ist der Richter im Gerichtshof Gottes:

8. Verzeihe mir wegen der Sichtweise Pīr Mūsīs. Hilf mir! Ich schreie um Hilfe.

(Kälām Nr. 17)

Seine Aufgabe war, den Sultāan Sähāk überall zu begleiten und all seine Taten und Worte niederzuschreiben:

11. Pīr Mūsī ist der Schreiber des Himmels. Und wenn jemand dieses nicht akzeptiert, dann ist er ein Apostat und wird seinen Weg verlieren.

(Kälām Nr. 50)

Da Pīr Mūsī ein Gūrānīsch Sprechender war, gibt es manche Kälāmāt in der gūrānīschen Kälāmāt, deren Urheberschaft ihm zugeschrieben wird. In der Kälāmāt-1 torkī stößt man lediglich auf seinen Namen als eine der sagenhaften Figuren.

Die iranische Kosmogonie kennt einen anderen, kosmischen Schriftsteller Tīr, der mit Mūsī assoziiert werden kann (vgl. Kreyenbroek 1992, S. 70).

Die Yārıstān meinen, dass ein Mausoleum in der Stadt Kerend (ca. 50 km von Šeyxān) Pīr Mūsī gehört (vgl. Dehkhoda 1968, Band 39, S. 479). 
Einen besonderen Platz in der Yārıstān nimmt die Helferin von Sulțān Säḥāk ein, die Rämzbār heißt. Die Yārıstān-Gläubigen nennen sie „Heilige“, „Reine“, „Herrin“. Sie beaufsichtigt das Ritual „Xıdmät“ - das Ritual der Zubereitung und des Speisens im Jäm, wofür die Frauen in der Yārıstān zuständig sind:

10. Verzeihe dem Sünder Qul Väli1 ${ }^{50}$ wegen der Xıdmät ${ }^{51}$ von Rämzbār.

(Kälām Nr. 1)

Rämzbār kann viele andere Gestalten annehmen, z. B. die Gestalt eines sagenhaften Vogels namens Sīmürğ, meint Säyyed Kāżem Nīknežād:

21. qušlar yeqilub gäldi hamusi

22. Sīmürg̉a Qāf dagin bayquya vīrāna virdilär
21. Alle Vögel sammelten sich, um ihre Güte zu bekommen

22. Sīmürğ hat den Gipfel vom Berg Qāe ${ }^{52}$ bekommen und eine Eule hat eine Ruine bekommen.

(Kälām Nr. 46)

Der siebte in der Sieben-Wesen-Hierarchie ist Müștäfā Dāvūdān, der Rächer und der Allmächtige. Als ein Ausdruck des Zorns Gottes hat er die Bevollmächtigung, die Feinde zu bestrafen:

6. Des Griffels (der Feder) von Pīr Mūsī und des zornigen Müșțäfās wegen begnadige mich.

(Kälām Nr. 1)

Da Müșțäfã für den Austritt der Seele aus dem Körper verantwortlich ist, lässt er sich mit dem Todesengel ‘ Äzrā’ēl vergleichen (vgl. Kreyenbroek 1992, S. 70; Xodābändeh 2004, S. 41).

Die Kälāmāt-1 torkī sowie die Äsrār-e Yārī von Säyyed Kāżem Nīknežād enthalten nur wenige Zeilen über Müșțäfā. Der Tod, die Strafe und die Rache haben in der Yārıstān kaum Bedeutung, weil der Kern der Yārıstān-Weltanschauung die Idee der Unsterblichkeit eines Menschen ist: die Yārıstān-Gläubigen haben eine unbegrenzte Möglichkeit, sich durch die Seelenwanderung zu vervollkommnen. Demnach finden sich in der Yārıstān-Literatur auch keine Vorstellungen über Hölle oder Paradies.

\footnotetext{
${ }^{50}$ Qül Välī - der Name des Kälāmsdichters.

${ }^{51}$ Xıdmät heißen alle Aufgaben, die mit dem Ritual der Zubereitung, und dem Speisen im Jäm in Verbindung stehen. Für diese Taten sind die Frauen zuständig. Rämzbār beaufsichtigt diesen Prozess.

${ }^{52} \mathrm{Q} a ̄ \mathrm{f}$ ist ein märchenhafter Berg am Ende eines märchenhaftes Meers Qolzom, so populäre iranische Mythologie.
} 
Manche Pīrān rechnen eine weitere sagenhafte Figur - den Šāh Ibrāhīm (seine anderen Namen sind Äyvät und Ročyār) - als den Siebten der Sieben Wesen. Seine Aufgabe, die er von Sultāan Sähāk erhielt, war, die Yārıstān in Bäğdād und Ägypten zu organisieren. Šāh Ibrāhīm ist dadurch zu einem der 16 Xānıdān-Gründer in der Yārıstān-Geschichte geworden. Seitdem die Stadt Bäğdād zum Sitz von Šāh Ibrāhīm ernannt wurde, bekam sie auch einen Sonderplatz in der Kälāmāt.

Säyyed Kāżem Nīknežād in Āyīn-e Yārī erzählt von einem der Kälāmāt-1 torkī Dichter mit dem Namen Ibrāhīm Quščiog̉l, dass er taubstumm geboren und in Bägdād vom Šāh Ibrāhīm geheilt wurde.

Der Vater von Quščıoglı diente als Falkner beim türkischen Sulțān Sälīm. Als Sulțān Sälīm den Iran angriff und sich mit seiner Armee an der Grenze zwischen dem Iran und der Türkei befand, ging er mit seinem Falkner auf die Jagd. Im Besitz Sulțāns gab es viele kostbare Jagdvögel. Der liebste Vogel Sulțāns war ein hübscher Falke. Der alte Yä qūb Quščı - der Vater vom Dichter Quščığlı - war während der Jagd durstig und suchte nach einer Wasserquelle. Er fand einen tropfenden Bach und sammelte Wassertropfen in seiner Feldschüssel, als der Falke mit seinem Flügel plötzlich die Schüssel umkippte. Der Falkner schlug vor Wut den Falken tot und begriff sofort, dass der Tod ab jetzt ihm selbst auch drohte. Er suchte nach Rat unter den Einheimischen und bekam ihn: es lebe in Bäğdād ein Heiliger Namens Šāh Ibrāhīm, der ihm helfen könne. Yä`qūb Quščı ging nach Bäğdād und sprach den Heiligen an. Šāh Ibrāhīm wollte von ihm als Belohnung einen seiner Söhne bei sich sehen. Der Alte hatte viele starke Söhne und fragte den Šāh Ibrāhīm, welchen seiner Söhne er wollte. Šāh Ibrāhīm wollte den jüngsten, der taubstumm war und Ibrāhīm hieß. Yä qūb Quščı brachte seinen jüngsten Sohn nach Bäğdād zu Šāh Ibrāhīm. Der jüngste Sohn und der Falke wurden durch Šāh Ibrāhīm geheilt. Der junge Quščığlı blieb bei Šāh Ibrāhīm als sein Schüler und wurde von ihm zu einem Yār erzogen. Nach einer Weile schickte Šāh Ibrāhīm den Quščioġlı nach Täbrīz, wo er in seiner Muttersprache - Türkisch - die Gemeinde zu leiten und seine Reden zu halten hatte. Quščıġlı erzählt über dieses Geschehen an mehreren Stellen seiner Gedichte:

11. Ich ging von Bägdād nach Täbrīz. Ich wusste, dass die Wahrheit mein einziges Kapital ist.

12. Ich habe keine große Satteltasche voll von Goldmünzen, wie die reichen Kaufmänner haben.

13. Ich bin in dich verliebt. Ich wünsche mir, dass du mein Geliebter 
und mein wahrer Freund wirst.

14. Mein Handel ist die Wahrheit. Ich habe mit der Eitelkeit nichts $\mathrm{zu}$ tun.

15. Ich bin voll Schmerzen geblieben. Ich habe kein Heilmittel für meine Schmerzen. Wisst Bescheid, ihr Freunde der Wahrheit,

16. Dass ich außer den „Dälīl o Täkbīr ${ }^{\text {‘53 }}$ für meine Schmerzen keine Pflege habe.

17. Du (Freund der Wahrheit) warfst den Ibrāhīm Quščiogilı in die brennende Trennung von den Freunden.

18. Du bist immer weiter meine Hoffnung, außer dir habe ich keine andere Hoffnung.

(Kälām Nr. 12)

5. Ich war ein Stummer und deswegen traurig.

6. Šāh Ibrāhīm sagte zu mir: „Sprich!“ Seitdem spreche ich. Ich bin jetzt ein Sprechender.

(Kälām Nr. 129)

Die Yārıstān kennen einen Menschen namens Šāh Ibrāhīm, den Sohn von Muhammad Gorasävār, einen der 72 Pīrān. Kāżem Nīknežād erzählt im Gänj̄̄nneh-e Zärnegār, dass Šāh Ibrāhīm in Bäğdād starb und sein Mausoleum sich am Rand dieser Stadt befindet.

\subsection{Die Geschichte der Yārıstān}

In der Äsrār-e Yārī von Säyyed Kāżem Nīknežād sind 15 Ären der Geschichte der Yārıstān genannt:
1. Perlenära
6. Šāh Xošīn-Ära
11. Bābā Jälīl-Ära
2. Yā-Ära
7. Bābā Nāvūs-Ära
12. Bābā Särhäng-Ära
3. Xāvändigārī-Ära
8. Šāh-Fäẓl-Ära
13. Sulțān Säḥāk-Ära
4. Menschenentstehung
9. Bohlūl-Ära
14. Bābā Yādıgār-Ära
5. Movlāyi-Ära
10. Sulțān Mäḥmūd-Ära
15. Säyyed Xeyālä-Ära

53 „Dälīl o Täkbīr“ ist das Segnen im Jäm unter der Aufsicht von Bınyāmīn und Dāvūd. 
Die Weltentstehung fand in der Perlen-Ära statt (siehe Kapitel II.1.1.). Der Schöpfer erschien dabei im Körper von Sulțān Säḥāk und schuf seine sieben Helfer, sowie Himmel und Erde:

1. Wo ist der Schöpfer der Welt und der Existenz?

2. Tage und Nächte rufe ich ihn.

3. Er schuf in der Vorzeit eine einzige Perle.

4. Er war selbst in der Perle, wovon keiner wusste.

5. Er blinzelte die Perle an -

6. Die Perle taute auf und wurde zu Wasser und machte die Welt voll von Wasser.

7. Aus Perlmutt baute er Gebirge auf.

8. Aus dem Taudampf schöpfte er den Himmel.

(Kälām Nr. 288)

Das erste Jäm unter Führung Dāvūds und mit Bınyāmīn als Särjäm und die erste Särsıpārî́ ${ }^{-54}$ für die Sieben Wesen fanden schon in dieser Ära statt (siehe Kapitel II.1.1.). Mit der Schöpfung von Šāh Ibrāhīm geht die Perlen-Ära bzw. die Vorgeschichte der Yārıstān zu Ende und fängt die Yā-Ära an.

In der zweiten Ära - Yā-Ära - kehrt Sulțān Sähāa in die ursprüngliche Einheit mit Wahrheit zurück und bleibt 15 Millionen Jahren lang bei ihr. Über diese Zeitspanne sprechen Yārıstān als über eines der Geheimnisse von Sulțān Säḥāk. Dann erscheint er als Xāvändıgār (dementsprechend heißt die nächste, die dritte, Ära „Xāvändıgārī-Ära“) bzw. Gott, der die Sonne und die ganze Natur entwickelt:

Gott (Xāvändıār) nannte sich der Gebieter von Himmel und Erde.

\section{(Äsrār-e Yārī)}

Säyyed Kāżem Nīknežād erzählt weiter über die Sonnenschöpfung von Xāvändıgār aus seiner eigenen Helligkeit und Wärme und zitiert dabei ein gūrānīsches Kälām:

1. hanit gorowy makrân zâry

2. na jam nishīny la sâjinâry
1. Es gibt eine Gruppe von Yārıstān, die weinen,

2. Sie sitzen im Jäm, als ob sie in $S a \bar{a}-1$

\footnotetext{
${ }^{54}$ Särsipārī heiß wörtlich „Unterwerfung“ und ist mit der christlichen Taufe vergleichbar (mehr dazu im Kapitel VI.2.b).
} 


$$
\text { Nār } r^{55} \text { sind. }
$$

3. nârish âftâwâ sâjish dyâry

3. Das Feuer ist die Sonne und Sâj ist die Erde.

Am Ende der Xāvändıgārī-Ära hat Xāvändıgār versprochen, in seinem letzten Körper als Sulțān Säḥ̄ā wieder zu erscheinen:

$$
\begin{aligned}
& \text { Ich nenne mich Sulțān Sähạā, } \\
& \text { Um für die Yārān sichtbar zu werden. }
\end{aligned}
$$

$$
\text { (Äsrār-e Yārī) }
$$

Die vierte Ära ist die Ära der Menschenentstehung. Äsrār-e Yārī erzählt, dass Gott auf der Insel Särändīb (Ceylon) erschien, um die vier Engel zu erschaffen: Ĵ̀brā’̄̄l, Isrāfîl, Mīkā’̂̄l und ‘Äzrā’̄il. Die Kälāmāt-1 torkī behauptet aber, dass Gott die Sieben Wesen während der Menschenschöpfung dabei hatte:

9. Die Sieben Wesen schrieben auf dem Himmelgewölbe.

(Kälām Nr. 288)

Diese sollen ihm bei der Menschenschöpfung geholfen haben. Den Menschen hat Gott 770 Jahre lang gestaltet. Dafür brauchte er 366 Knochen und 444 Venen. Danach hat er einen Teil von seinem eigenen Funken ${ }^{56}$ als Seele für den Menschen abgegeben.

12. Aus einer Hand voll Lehm hat er den Menschen geschaffen.

13. Ein Pferd kam, die Menschengestalt zu zerstören.

14. Aus seinem Nabel schuf er einen Wächter.

15. 770 Jahre blieb der Körper aus Lehm liegen.

16. Dann wurde Leben zu den 444 Venen gegeben ...

31. Wir sind von Anfang an die Kälzärdä (die Opfertiere) und gehören dem Anfang der Schöpfung.

(Kälām Nr. 288)

Der Funke allein konnte den menschlichen Körper nicht beleben, und erst als Sulțān Säḥāk die Liebe hinzugab, war der menschliche Körper fähig, die Seele anzunehmen:

17. Ohne Liebe blieb das Leben aber nicht im Körper.

\footnotetext{
${ }^{55}$ Sāj-i Nār heißt wörtlich ,eine umgekippte Pfanne auf dem Feuer“.

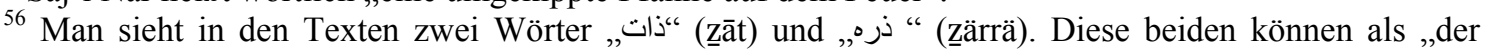
Funke“ oder aber als „die Essenz“ übersetzt werden. Im Yārıstān-Lexikon ist aber die Bedeutung „,der Funke" gebräuchlich.
} 
18. Der Körper und die Liebe harmonierten und nahmen Leben an.

(Kälām Nr. 288)

Der Schöpfungsakt des Menschen war zu Ende:

19. Nachher konnte man einatmen und ausatmen ohne dieses zu merken:

20. Diese haben kein Kennzeichen und sind nicht zu erkennen.

21. Der Mensch nieste und stellte sich auf seine Beine.

(Kälām Nr. 288)

Die fünfte Ära ist die Movlāyi-Ära, während welcher Gott als Imam `Älī den Schiiten erschien:

7. Das Gesicht der Yārıstān in der Öffentlichkeit und im

Geheimleben ist das beliebteste Gesicht von `Älī.

8. Ich wünsche mir den König der Herren ( $($ Älī), dem auch das

Geheimhaus (Ĵ̈m-Xāna) zugänglich ist.

(Kälām Nr. 151)

In der sechsten Ära - Šāh Xošīn-Ära - verkörperte sich die Wahrheit bzw. Sulțān Säḥāk als Šāh Xošīn. In dieser Erscheinung wurde er zum Vorzeichen dafür, dass Sulțān Säḥāk bald wieder in seiner eigenen Gestalt zu den Yārıstān kommen würde. Die Äsrār-e Yārī berichtet über Šāh Xoš̄̄n kaum: er war ein König und hatte unter seiner Führung eine Yārıstān-Gruppe aus 900 Yārān; er gab bekannt, dass seine nächste Verkörperung in Havrāmān, im Hause von Šīreh Xān, stattfinden werde. Dafür werde es auch ein Zeichen geben: ein nicht gestimmter Tanbur werde plötzlich einen sauberen Klang haben. So sollte auch die nächste, die siebte, Ära - die Bābā Nāvūs-Ära begonnen werden. Darüber berichtet in der Äsrār-e Yārī ein gūrānīsches Kälām:

1. nâm-i män bela shuhratim nâûūs

1. Ich heiße Bela, mein Nachname ist Nāvūs,

2. bâbom Ahmadan sâhib-i jâ u kûs

3. Piykânim wa sar jûqi-i par tâwûs

4. Zât-i âswâ nihân chany kiykâwûs
2. Mein Vater heißt Äḥmäd, der prächtig ist und einen Kampftrommel besitzt.

3. Mein Pfeil hat eine Spitze aus Pfauenfeder.

4. Ich bin der Funken, der einmal dem 
Körper von Käykāvūs ${ }^{57}$ gehörte.

5. qâzî u qâzim

6. xwâjâm nâûsâ qâzî u qâzim

7. yârân intizâr na kûk-i sâzim

8. izin xwâjâm bê na gîr-i gâzim
5. Mein weiterer Name ist Qāẓ̄.

6. Ich bin eine Verkörperung von Bābā Nāvūs.

7. Ihr, Yārān, wartet auf einen gestimmten Tanbur-Klang.

8. Das war der Wille meines Gottes, dass ich mich weiter quäle.

Šāh-Fäẓl-Ära ist die achte Ära nach der Ärenauflistung in der Äsrār-e Yārī. Es gibt einen anderen Namen für diese Ära - Dāmyārī-Ära (,die Viehpflege“).

Die Erzählung über die Šāh-Fäẓl-Ära in der Äsrār-e Yārī beruht nur auf der gūrānīschen Kälāmāt:

1. ghulâmân ghazla

2. maydân-i yârî hawshû ghazla

3. chanî chihiltanah kirdimân fazlâ

4. na dowrih-i mowlâ shîm aw shâh fazlâ
1. Hört, ihr Yārān, zu,

2. Auf dem Yārıstāns Helden-Feld fehlen die Taten von Dāvūd.

3. Ich war einer der Vierzig Personen,

4. Ich ging mit dem Funken von Movlā in den Šāh-Fäẓls Körper.

Alle vier Engel sind in der Zeit der Šāh-Fäẓl-Ära in den Menschen verkörpert und sind unter den Namen Mänșūr für Bınyāmīn, Näsīmī für Dāvūd, ZZäkäryā für Mūsī, ‘Äyna für Rämzbār bekannt. Gott wollte seine vier Engel in den menschlichen Gestalten prüfen: sie durften kein Lamm schlachten, kein Lammfleisch zubereiten und essen. Sie missachteten aber sein Verbot, schlachteten ein Lamm, kochten es und aßen es auf. Nachher sammelten sie die Knochen des Lammes und taten sie in das Lammfell hinein. Šāh-Fäẓl belebte dieses Lamm mit seinem Holzstab wieder. Am nächsten Tag fand die gleiche Geschichte mit demselben Lamm statt. Gott sah, dass diese Vier, obwohl sie wussten, dass ihre Tat falsch war, nicht aufhören konnten und sich dem Fehler immer wieder ergaben. `Äyna bzw. Rämzbār erzählt darüber in einem gūrānīschen Kälām:

1. haqim wât chana

2. ¿̇yni bayânî haqim wât chana

${ }^{57}$ Ein iranischer mythologischer König.
1. Ich sagte ihnen die Wahrheit.

2. Ich war `Äyna [Rämzbār], sagte ihnen die Wahrheit. 
3. na fasl-i bara yâwâymî pana

4. man wâtim hiy na mansûr bîxana
3. Als sie das Lamm schlachteten,

4. Ich sagte ihnen immer noch die

Wahrheit, aber Mänșūr lachte.

Eine Weile, so die Äsrār-e Yārī, befand sich Gott im Körper von Bohlūl. Diese Zeitspanne heißt demnach die Bohlūl-Ära (die neunte ${ }^{58}$ Ära). In der Zeit waren alle vier Engel - Bınyāmīn als Bābā Loreh, Dāvūd als Räjäb, Rämzbār als Nujūm und Mūsī als Ḥātäm - auch bei Bohlūl, um ihm zu helfen:

Dâûd maramo:

1. amînim kardan

2. bêlwîl xudâmâ amînim kardan

3. hâtamish na bahr qulzum âwardan

4. dânâyî wan xalkân dîwâna kardan
Dāvūd sagte:

1. Ich glaubte:

2. Dass der Funken von Gott in Bohlūl strahlt - glaubte ich.

3. Den Ḥātäm (Mūsī), der aus dem ewigen Ozean geschaffen wurde, brachte man zu mir.

4. Bohlūl ist der Weise, obwohl die Menschen ihn einen Wahnsinnigen nennen.

Der reale Bohlūl ist berühmt. Seine historische Existenz kann anhand der in den wesentlichen Punkten übereinstimmenden Quellen als gesichert gelten, so Ulrich Marzolph (1983). Er war ein iranischer Kurde, der sich als einen Wahnsinnigen vor der damaligen Öffentlichkeit darstellte, um die Wahrheit über seine Religion sprechen zu können. Er ist vor allem aber dafür bei den Yārıstān beliebt, dass er in der islamischen Zeit der erste war, der Jäm veranstaltete. Ali Akbar Dehkhoda (1968) nennt das Jahr 190 (805) als das Sterbejahr von Bohlūl (vgl. Dehkhoda 1968, Band 11, S. 429).

Die Sulțān Mäḥmūd-Ära ist die zehnte Ära der Geschichte der Yārıstān. Ihren Namen verdankt diese Ära einer realen Figur in der iranischen Geschichte, einem der mächtigsten Sulțāns in islamischer Zeit im Iran - dem Sulțān Mähmuñd von Ghazna. Seine realen Taten sind als Ğehād (der heilige Krieg der Muslimen) gegen indische Völker und andere nicht Islam-Gläubigen bekannt. Die moderne Geschichte Irans stellt ihn als einen gnadenlosen Militanten, einen Massakrierer dar (vgl. Zärīnkūb 1951; Spuler 1994, S. 199-212). Es gibt aber keine Übereinstimmungen zwischen seiner

${ }^{58}$ Die Bohlūl-Ära steht bei Säyyed Kāżem Nīknežād in der Auflistung von 15 Ären in Bezug auf die Wichtigkeit an neunter Stelle. Geschichtlich fällt sie aber auf die fünfte Stelle, da sie dem 3. (8.) Jahrhundert entspricht. 
offiziellen Biographie aus den wissenschaftlichen Quellen und der Darstellung seiner Biographie in der Äsrār-e Yārī. Nach Auffassung der Äsrār-e Yārī war Sulțān Mäḥmūd ein großer Held, der einen bösartigen Drachen tötete, um die Stadt Kerend (in der Provinz Kermānshāh) von dessen Angriffen zu befreien. Während Sulțān Mäḥmūd den Drachen bekämpfte, brachten die Einheimischen seine Begleiter - die vier Engel (Äyāz bzw. Bınyāmīn, Käräm bzw. Dāvūd, Bādīleh bzw. Rämzbār und Häsän bzw. Mūsī) um. Sulțān Mäḥmūd rief die Strafe Gottes, und alle Bewohner wurden von Gott gesteinigt. Drei Mausoleen sind in der Nähe des Geschehens immer noch zu sehen: in der Region Nävā für Äyāz, im Dorf Ṭelesm für Käräm und im Dorf Zärdeh Kerend für Häsän.

Die elfte Ära ist die Bābā Jälīl-Ära. Gott erschien in der Region Dāvūdān, in Havrāmān, als Mensch namens Bābā Jälīl. Seine Begleiter hießen Mīrzā Qolī (Bınyāmīn), Bägtär (Dāvūd), Sāy’i (Mūsī) und Sämän (Rämzbār). Diese Ära zeichnet sich nach der Erzählung der Äsrār-e Yārī lediglich durch die Gutmütigkeit und die Bescheidenheit Bābā Jälīls aus.

Die Bābā Särhäng-Ära ist die zwölfte in der Ärenauflistung in der Äsrār-e Yārī. Zum 1000. Mal erschien Gott im Menschenkörper und hieß Bābā Särhäng. Seine sechs Begleiter waren dieses Mal alle dabei: Yoränj (Bınyāmīn), Gärčäk (Dāvūd), Säbūrä (Rämzbār), Qeyșär (Mūs̄̄), Soränj (Müșțäfā), Tauriz (Bābā Yādıgār). Diese Ära hat mythische Inhalte: Gott im Körper von Bābā Särhäng verwandelte sich in einen Falken, und der Mensch Bābā Särhäng starb. Als ein weißer Falke erschien Gott nach 500 Jahren in einem Garten, in der Nähe der Brücke namens Pīrdävär beim Dorf Šeyxān (Havrāmān) wieder und wurde von Bınyāmīn erkannt. Dieser Falke war also die 1001. Verkörperung Gottes. Bınyāmīn nahm den Falken und gab ihn an Rämzbār weiter. Auf ihrem Arm verwandelte sich der Falke in ein Kind. So wurde Gott im Körper vom Sulțān Säḥāk auf der Erde wieder geboren, und dadurch hat er sein Versprechen auch eingehalten. Das war der Anfang der dreizehnten Ära, der Sulțān Säḥāk-Ära. Darüber berichtet in der Äsrār-e Yārī ein Gūrānīsches Kälām (links), das von Kāżem Nīknežād auf Persisch erzählt wurde:

1. pânsad sâl wa sirr wist aw awrâmân

(Er lebte 500 Jahre geheim in Havrāmān)

2. binyâmîn âwird shâhbâz na bûstân
1. Nach 500 Jahren, nachdem Gott in Havrāmān im Geheimen lebte,

2. Erschien er in einem Garten als Falke. 
(Bınyāmīn brachte den Adler zum

Garten)

3. binyâmîn girdî dâûd âsânî

(Bınyāmīn fing ihn und Dāvūd nahm von ihm)

4. dâsh wa dâyrâk bê wa dâyânî (gab ihn Rämzbār, der Mutter Adlers)

5. dâyrâk maramo: farzandâ mîn shâhbâz-i Sifîd madrây na kamîn na sar quliy-i ¿̇arsh âmây wa zamîn

(Rämzbār sagte: „Du, mein Kind, das als der weiße Adler vom Gipfel des Himmels auf die Erde kamst")
Bınyāmīn erkannte und fing ihn.

3. Bınyāmīn und Dāvūd sahen den Falken an und gaben ihn Rämzbār.

4. In den Händen Rämzbārs wurde der Falke ein Baby.

5. Rämzbār sagte: „Mein Kind, du kamst vom Himmel auf die Erde“.

In der Kälāmāt-1 torkī finden sich auch Zeilen, die dieses Ereignis darstellen:

3. Dieser (Sulțān Säḥāk) kam auf die Welt in tausend und einer Gestalt.

4. Seine (letzte) Gestalt (als Sulțān Säḥāk), die bei Pīrdävär erschien, lieben sie.

(Kälām Nr. 60)

In der Äsrār-e Yārī und in der Āyīn-e Yārī finden sich einige Erzählungen über die Wunder, die Sulțān Sähāa in dieser Ära vollbrachte. Ein Wunder ist bei den Yārıstān besonders beliebt und wird im Jäm gelegentlich erzählt. Als Sulțān Säḥāk von seinem Heimatdorf Bärzänĵeh in Šār-1 Zūr (Nord-West Kurdistan) in das Dorf Šeyxān in Havrāmān, das später zu seinem Hauptsitz wurde, umzog, traf er am Fluss Sīrvān mehrere Dorfbewohnerinnen, die dort gerade ihre Gefäße mit Wasser aus dem Fluss füllten. Er fragte nach ihren Männern. Sie antworteten, dass sie Sulțān Säḥāk entgegen gingen, um ihn zu begrüßen. Dieser Fluss hatte ein Felsenufer. Sulțān Säḥāk zeigte mit seinem Stock auf eine Stelle auf den Felsen. Drei Quellen sprudelten sofort aus den Felsen heraus.

Die Dorfbewohnerinnen holten sich dieses Wasser und probierten es. Das Wasser schmeckte wunderbar.

Diese drei Quellen sind in Havrāmān noch heute bekannt und bieten trinkbares Wasser an. Sie heißen Ṭäšār. 


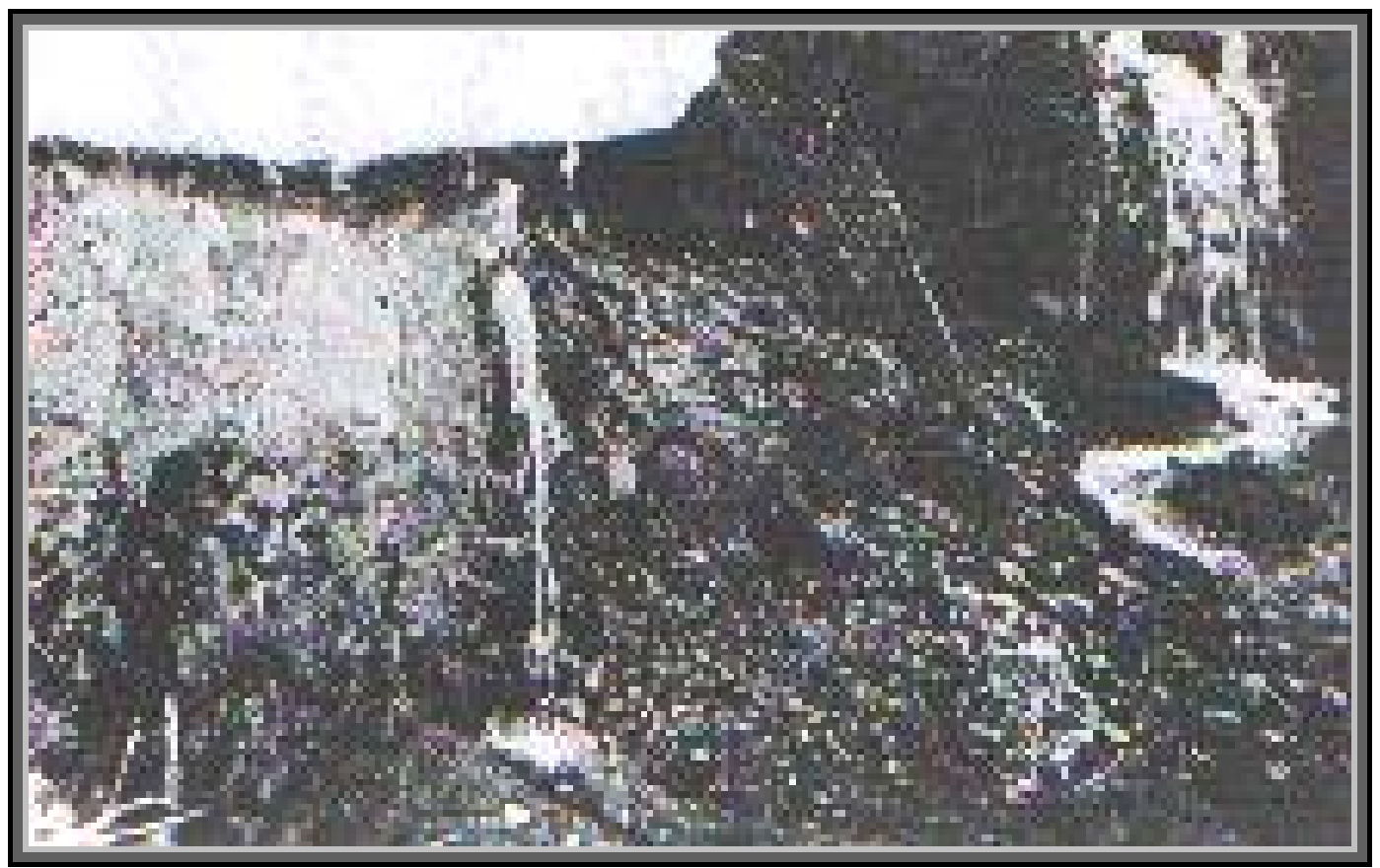

Ṭäšār-Quellen

(ein Foto aus der Handschrift „Gänj̄̄neh-e Zärnegār" von Säyyed Kāżem Nīknežād). 
Was für ein himmlisches Gefühl ein Yār bekommt, wenn er aus diesen Quellen trinkt, erzählt die Kälāmāt-1 torkī:

1. Kommt, kommt ihr Yārān, hört euch diese Geschichte an.

2. Trinkt Šärbät von meinem Herrn, seid betrunken.

3. Mit meiner Zunge erzähle ich diese Geschichte und beobachte eure durch Šärbät betrunkenen Augen.

4. Reisend durch Rūmıstan (Byzanz oder Ausland), kam ich zu einem Blumengarten.

5. Ich sah dort einen Herrn. Als ich ihn sah, fing die Welt an zu strahlen.

6. Ich kaufte eine Perle - ich verkaufte eine Perle: so näherte ich mich der Perlenmine.

7. Als ich die Perlenmine erreichte, trank ich Wasser aus der Ṭäšār-Quelle. Das Herz Gottes nahm mich an.

8. Tausende Blumen blühten im Garten auf. Ich wurde zu einer Nachtigall in diesem Garten.

9. Was liest Quščıg dem Koran)?

10. Als er (Quščıġlı) sich wünschte, den Thron der Sieben Wesen zu sehen, marschierten sie (die Sieben) vor ihm.

(Kälām Nr. 227)

Das Wasser, das im Jäm nach jedem zeremoniellen Mahl getrunken wird, wird in der Vorstellung mit Wasser aus diesen drei Quellen assoziiert.

Zum einen lässt sich dieses Wunder von Sulțān Sähāk mit einem ähnlichen Wunder von Mithra vergleichen. Anstatt mit einem Stock auf den Felsen zu zeigen, schieß Mithra (in römischer Tradition) einen Pfeil in den Felsen (vgl. Hinnels 1975, S. 124). Zum anderen findet sich in der Äsrār-e Yārī in der Erzählung über die Yādıgār-Ära eine Behauptung Sulțān Sähāāks, dass das Wasser aus der Gäslān-Quelle, die aus der Hand Yādıgārs entstand, das gleiche wie das Wasser aus den Ṭäšār-Quellen ist.

Eines der wichtigsten Geschehnisse in der Sulțān Sähāk-Ära ist die Schöpfung von sog. Häftäwāna. Während die Sieben Wesen für die himmlischen Angelegenheiten verantwortlich sind, sind ihre sieben Verkörperungen bzw. Häftäwānä für die irdischen Aufgaben zuständig und heißen Säyyed Muhammad-1 Sūr, Säyyed Bulväfā, Mīr Sūr, 
Säyyed Mūstäfā, Šeyx Šähāb-od-dīn, Šeyx Häbīb Šäh, Hāīībābā 'Īsā. In einer mythologischen Erzählung der Äsrār-e Yārī wird ihre Schöpfung wie folgt dargestellt. Der Führer der Provinz Loristan Mīr Xosro hatte einmal ein edles Pferd. Der Šāh vom Iran wollte dieses Pferd um jeden Preis bekommen. Mīr Xosro verbarg das Pferd. Der Šāh war wütend und hielt Mīr Xosro in einem unterirdischen Gefängnis fest. Mīr Xosro betete zu Sulțān Säḥāk und bekam seine Hilfe: Dāvūd befreite ihn. Mīr Xosro, seine Schwester, sein Pferd und Dāvūd machten sich auf den Weg zu Sulțān Säḥāk. Dort wurden sie von Sulțān Sähāk empfangen und veranstalteten alle gemeinsam ein Jäm. Die Schwester von Mīr Xosro durfte sich während der Jäm-Veranstaltung nicht im Ĵäm aufhalten. Als Jäm endete, bat Sulțān Säḥāk sie wieder hinein. Sie kam und gebar vor Augen aller Anwesenden sieben Söhne. Diese waren die Sieben Mächte bzw. sieben Verkörperungen der himmlischen Sieben Wesen.

1. Der König schenkte der Herrin Bäšīra besondere Aufmerksamkeit:

2. Niemand darf dieses Geheimnis nachvollziehen.

3. Bınyāmīn, Dāvūd und Pīr Mūsī

4. Traten ins Haus wie ehrliche Diener ein (dem König wahrhaftig zu dienen).

5. Als Er (der König) die Aufmerksamkeit der Herrin Bäšīra schenkte,

6. Erschienen in diesem Moment die Sieben Mächte auf der Welt.

7. Die Sieben Wesen erstaunten vor dem Geschehen.

8. Keiner von ihnen konnte dieses Geheimnis nachvollziehen.

9. Der König rief laut:

10. „Wer gab dem Pīr (den Sieben Wesen) die Macht (zu verstehen)?

11. Als ich den Ring ins Meer hineinwarf,

12. Wer brachte diese Nachricht dem Heiligen Mīr ${ }^{59}$ ?“

(Kälām Nr. 215)

Die Yārıstān erwarten, dass Sulțān Sähāa noch viele Heldentaten unternehmen wird, um die Yārıstān und die Welt zu retten.

\footnotetext{
${ }^{59}$ Mīr (bzw. Mīr Sūr) ist einer von den Sieben Mächten.
} 
Die vierzehnte Ära ist die Bābā Yādıgār-Ära. Im Zentrum des Geschehens in dieser Ära steht der sagenhafte Bābā Yādigār.

Die fünfzehnte Ära heißt Säyyed Xeyālä-Ära. Bābā Yādıgār hatte keine eigenen Kinder und ernannte deswegen Säyyed Xeyālä, seinen liebsten und ausgewählten Schüler, zu seinem Nachfolger. Diese Ernennung wurde auch von Šäkär, der Verkörperung von Pīr Mūsī, und von Šāh Ibrāhīm bestätigt. Viele Yārıstān meinen, dass sie noch heute in der Säyyed Xeyālä-Ära leben und erwarten ein Wunder, das diese Ära auszeichnen wird.

Außer den bisher erwähnten 15 Ären gibt es mindestens noch eine - die sechzehnte und heißt „Gelīm vä Kūl““. Obwohl die Äsrār-e Yārī über diese Ära nichts erzählt und sie nicht erwähnt, gibt es eine ausführliche Darstellung dieser in einer anderen Handschrift von Säyyed Kāżem Nīknežād - Āyīn-e Yārī. Im Unterschied zu den 15 Gottes-Ären ist die Gelīm vä Kūl-Ära allein dem ersten Engel Gottes Bınyāmīn gewidmet, dem Gesetzgeber der Yārıstān.

„Gelīm vä Kūl““ bedeutet auf Gūrānīsch wörtlich „Matte auf dem Rücken“ und meint einen Elenden, der Matten statt Kleidung trägt.

Āyīn-e Yārī erzählt, dass ein Schiff auf dem Nil ${ }^{60}$ unterwegs war, als ein großer Sturm das Schiff schüttelte. Die Passagiere - ein Kaufmann mit seinen Begleitern - fingen an, zu beten und zu heulen. Das Schiff bebte weiter. Unter den Passagieren war ein Elender mit Matte statt Kleidung. Der Mann war ein Ähl-1 Häqq („Mensch der Wahrheit"“). Die Kaufleute sagten, dass dieser Arme das Unglück verursachte, und wollten ihn ins Wasser werfen. Gott hörte aber das Gebet des Elenden und schickte Dāvūd zu ihm. Dāvūd rettete sowohl den Elenden als auch alle anderen auf dem Schiff. Der Kaufmann fragte, wer der große Retter sei? Der Arme antwortete: „Du reicher Dummkopf, er war Dāvūd, weil mein Gebet den Gott erreicht, und ich bin Bınyāmīn.“ Der Kaufmann meinte, dass er doch blind und dumm gewesen ist. Binyāmīn lud ihn ein, ins Jäm mitzugehen. Alle gingen gemeinsam ins Jäm und wurden zu Yārıstān.

Diese Geschichte ist eine der beliebtesten Geschichten in den Yārıstān-Reden. Sie wird von den Gemeindemitgliedern immer wieder gern gehört.

${ }^{60}$ Während in Āyīn-e Yārī der Fluss Nil genannt wird, habe ich im Jäm von Pīr Ibrāhīm Sähākī das Mittelmehr gehört. 


\section{Die Verbreitung der Yārıstān}

Um die geographische Verbreitung der Yārıstān in den letzten zwei Jahrhunderten darstellen zu können, kann man den Iranforschern, die die Yārıstān vor Ort untersucht haben, folgen. So nennt V. A. Žukovskij in seinem Buch „Секта людей истины“ (1887) die Städte Schirāz und Teheran (vgl. Minorsky 1911, S. VIII). Vladimir Minorsky traf die Yārıstān-Anhänger in Teheran, Hamadān und Makū (vgl. Minorsky 1911, S. IXf.).

G. Moradi meint, dass alle Begründer und Führer der Yārıstān ausnahmslos entweder Loren oder Kurden sind. Deswegen leben die Yārıstān meistens in Loristan und in Kurdistan (Moradi 1999, S. 51f.).

A. Xodābändeh nennt im Buch „Šenāxt-e Ähl-1 Häqq “ (2004) mehrere Städte und Dörfer in der Provinz Kermānshāh (wie z. B. Kermānshāh, Kerend-e gärb, Șäḥna, Särpol-e zähāb, Qäsr-e Schīrīn, Islamābād, Pāva, Jävānrūd, Härsīn) als Hauptquartier der Yārıstān. Als weitere Ansiedlungen der Yārıstān nennt der Autor einige Dörfer in den Provinzen Loristan, Zanj̄ān, Hamadān, Aserbaidschan, Gīlān, Māzandarān und Teheran (vgl. Xodābändeh 2004, S. 55-58). Allein in der Stadt Hamadān sind aber zehn Yārıstān-Xānıdān mit ca. 700 Familien präsent, so dass man auf keinen Fall Xodābändeh zustimmen kann, wenn er über „einige Dörfer“ in der Provinz Hamadān spricht. Genauso sind seine Angaben zur Provinz Zanĵān, in der auch lediglich „einige Dörfer“" von Yārıstān besiedelt seien, strittig. Eine ziemlich dicht von den Yārıstān bewohnte Provinz, nämlich Qäzvīn, sowie die Großstädte Täbrīz und Orūmyeh (Urmia) wurden vom Autor überhaupt nicht erwähnt.

Außerhalb des Irans, so Xodābändeh, leben die Yārıstān im Irak, in der Türkei, in Albanien $^{61}$, Syrien, Indien, Afghanistan, Pakistan, Tadschikistan und Zentralasien ${ }^{62}$ bis zum Pamir. Es leben auch viele Yārıstān in Europa und den USA (vgl. Xodābändeh 2004, S. 58-61). Die Zahl der Yārıstān-Gläubigen, meint A. Xodābändeh, wird von den Gläubigen selbst übertrieben. Im Unterschied zu einigen Yārıstān, die selbst behaupten, dass es von ihnen drei bis sechs Millionen auf der Welt gibt, ist Xodābändeh der Meinung, dass es tatsächlich weniger als 500. 000 sind (vgl. Xodābändeh 2004, S. 65).

\footnotetext{
${ }^{61}$ Dieser Name hat geographisch und politisch gesehen nichts gemeinsam mit dem Land Albanien, das A.Xodābändeh als einen ehemaligen Teil der Türkei nennt (vgl. Xodābändeh 2004, S. 60). Tatsächlich war Albanien bis zur Mitte des 19. Jahrhunderts ein gebräuchlicher Name für die heutige Republik Aserbaidschan, die damals ein Bestandteil des Iran war (vgl. Reza 1989, S. 31-58).

${ }^{62}$ Xodābändeh bringt dafür aber keine Beweise.
} 


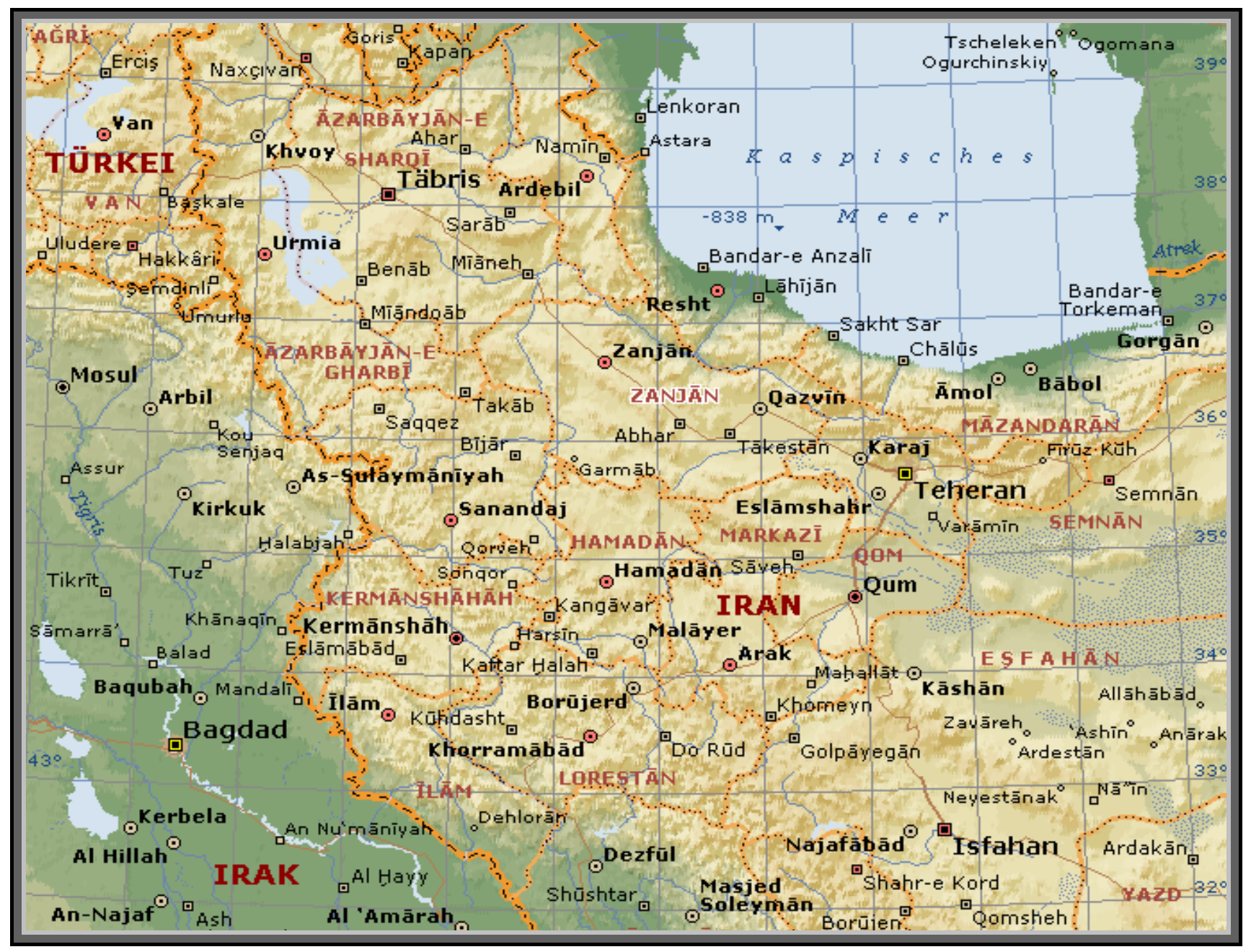

Verbreitung der Yārıstān in Mittleren Osten 
Die Kälāmāt-1 torkī berichtet an verschiedenen Stellen über das Ansiedeln von Türkisch sprechenden Yārıstān-Gläubigen und nennt unter anderem die folgenden Orte: Üzumdälı, Dikdaban, Yeddıqädäm, Qizqapan, Älänĵa, Näxjävān, Gärgär (in der Republik Aserbaidschan), Zünüz, Sufyān, Märänduz, Schamb-1 Qazan, Täbrīz, 'Eynalı, Äräsbārān, Tüklijäh (in der iranischen Provinz Aserbaidschan), Turkmenistan, Turkistan, auch Rūm bzw. Byzanz, Indien und Ägypten.

5. Ich wünsche mir Yārān, die in Uzumdälin, Dikdaban, Yeddiqädäm, Qizqapan

6. Und in Älänja, Näxjävān, Ordūbād ${ }^{63}$ leben,

7. Die weit weg von Gärgär, Zünüz, Șūfyān und Märänduz (leben).

8. Die unten in Šänb-1 Gazan, in Tabriz ${ }^{64}$ lebenden Yārān wünsche ich mir.

9. Die in $\bar{A} r a ̄ n{ }^{65}$ gebliebenen, die Yārān in 'Eyn ${ }^{e} a \bar{i}^{66}$,

10. Die mit den nomadischen Turkmenen lebenden KarawanenführerYārān wünsche ich mir.

11. Die Yārān, die im Winterquartier in Äräsbārān ${ }^{67}$ und in allen Sommerquartieren leben.

12. Die im Winter in Tuklıdag ${ }^{68}$ blühenden Frühlingsnarzissen wünsche ich mir.

(Kälām Nr. 130)

Aus der Kälāmāt-1 torkī entnimmt man folgende Hinweise auf die stattgefundene Ausweisung der Gūrān̄̄sch sprechenden Yārıstān aus dem Havrāmān in die Türkisch sprechenden Gebiete:

19. In meinem damaligen Körper sprach ich meinen König in deutlichem Gūrānī an.

20. Seitdem ich in diesen Körper gekommen bin, bin ich gezwungen, Türkisch zu reden.

(Kälām Nr. 45)

\footnotetext{
${ }^{63}$ Diese sieben Orte befinden sich in der Republik Aserbaidschan.

${ }^{64}$ Die folgenden sechs Orte befinden sich im iranischen Aserbaidschan.

${ }^{65}$ Ārān war bis 1828 eine große iranische Region, die durch die russische Besatzung Teil des russischen Reiches wurde und in die Länder Armenien, Georgien, Aserbaidschan geteilt wurde (vgl. Dehkhoda 1968, Band 5, S. 1612; Reza 1989, S. 11-19).

${ }^{66}$ Ein Gebiet in der Nähe von Tabriz.

${ }^{67}$ Ein Gebiet im iranischen Aserbaidschan.

${ }^{68}$ Ein Berg im iranischen Aserbaidschan.
} 
Die iranische Geschichte kennt diesen Umsiedlungsprozess von fast 60 kurdischen Völkern aus dem iranischen Kurdistan in die Städte Rey (jetzt ein Stadtteil in SüdTeheran), Šähryār, Qäzvīn (in der Mitte Irans) und datiert ihn auf Anfang des 10. (16.) Jahrhunderts (vgl. Dehkhoda 1968, Band 39, S. 431).

\section{Die Prinzipien der Yārıstān}

Die Weltanschauungs- und Moralprinzipien bilden die Basis des Glaubens der Yāristān.

1. Weltanschauungsprinzipien:

- die Wahrheit (Gott),

- die Seelenwanderung,

- die Weltrettung durch die Yāristān.

2. Moralprinzipien:

- Š̈ärț und Iqrār (,der Pakt" und „,die Verpflichtung“"),

- Hefz-e Äsrār („,die Bewahrung der Geheimnisse der Yārıstān bis zum Tod“)

- Täqyyä („die Verheimlichung“),

- soziales Gewissen der Gemeindemitglieder.

Auf Grundlage der Weltanschauungsprinzipien werden die Hierarchie und die Ordnung und auf Grundlage der Moralprinzipien werden Riten, Bräuche und Vorschriften innerhalb der Yārıstān entwickelt.

\subsection{Die Weltanschauungsprinzipien}

\section{a) Wahrheit (Gott)}

Gott ist die Quelle der Welt und die Welt an sich, er ist das Ziel und der Zweck des Lebens. Die Menschen, die Tiere und die Pflanzen enthalten Teile der Wahrheit bzw. Gottes:

9. Das Herz der Sieben Wesen ist die Behausung der Wahrheit.

(Kälām Nr. 49)

und streben nach Vereinigung mit dem Ganzen - mit der Wahrheit. Dabei sind die Yārıstān-Gläubigen bereit, sich „für die Vereinigung mit ihrem Geliebten“ zu opfern (vgl. Kälām Nr. 15). Unter „Geliebte“ versteht man die Wahrheit (d. h. Gott) und/oder ihren Ausdruck auf der materiellen, irdischen Ebene - den Sulțān Säḥāk. 
Sulțān Sähāk, alle Lebewesen und Dinge wurden aus einer Quelle, der Perle, die an sich schon Gott bzw. Sulțān Sähāa ist, geschaffen:

7. Mein Herr (Gott bzw. Sulțān Sähāa) ist einzigartig, er ist überall anwesend.

(Kälām Nr. 6)

Durch alle Geschöpfe wird die Wahrheit in der Welt verkörpert:

7. Die Freunde der Wahrheit (Yārıstān) hoffen auf das Wahrheitsgeheimnis.

8. Alle Geschöpfe haben ihre Anteile erhalten; Jeder Anteil enthält sein Skelett.

(Kälām Nr. 44)

Da Gott selbst die menschliche Gestalt annimmt und als Sulțān Säḥāk oder auch Sulțān Säḥāks liebstes Geschöpf Bābā Yādıgār erscheint, um für jeden Yārıstān auf der irdischen Ebene ansprechbar zu sein, kennen die Yārıstān keinen Propheten. So ist Sulțān Sähāk als Verkörperung Gottes für die Yārıstān-Gläubigen der größte sichtbare Ausdruck der Wahrheit:

1. Sehet aufrichtig den Xāvändıgār (Sulțān Säḥāk) als die Wahrheit, weil nur die Wahrheit-Liebenden so beobachten.

2. Er erschuf die Sieben Wesen mit Freude. Die Sieben Wesen lieben alle.

3. Xāvändıgār ist der Gipfel aller Geheimnisse,

4. Diese Sieben Wesen werden von der Wahrheit geliebt, sie sind ebenso das Heilmittel für eure Schmerzen.

5. Adlige Diener (Sieben Wesen) sitzen. Und die Wahrheit spricht sie an.

(Kälām Nr. 18)

Als sichtbarer Ausdruck der Wahrheit werden außer Sulțān Säḥāk und Bābā Yādigār auch Bınyāmīn, Dāvūd, Mūsī, Rämzbār, Müșțäfā verstanden. Diese Sieben Wesen, als die ersten Jäm-Gründer, werden immer im Zusammenhang mit dem Jäm gedacht.

11. Die Sieben Wesen sehen im Ĵ̈m ihre Wahrheit.

(Kälām Nr. 49) 
Sie sind in der Vorstellung der Yārıstān im Jäm immer anwesend und wirken heilend auf die Gläubigen.

1. Ich verlange von diesem Jam die Heilung für meine Schmerzen.

2. Ich wünsche mir, dass Šāh Xāvändıgār meine Schmerzen lindert.

(Kälām Nr. 49)

Man bringt heutzutage in das Jäm immer noch seine kranken Kinder in der Hoffnung, dass sie durch die dort anwesenden Sieben Wesen geheilt werden.

Wie einsam und „heimatlos“ sich ein Yār ohne das Jäm fühlt, das er als „Heilmittel“ bezeichnet, wie er leidet, wenn er von seinen Glaubensgenossen getrennt ist, lässt sich aus dem folgenden Kälām entnehmen:

1. In dieser Umgebung bin ich heimatlos, da kann ich keinen geliebten Freund der Wahrheit besuchen.

2. Mein Gesicht wurde endlos blassgelb, keiner interessiert sich für mein Dasein.

3. Ich bin heimatlos, ich bin durstig, ich bin jammernd. Für meine Schmerzen wird es kein Heilmittel geben.

4. In die Richtung der Wahrheit gehe ich flehentlich - außer dieser habe ich keine andere Möglichkeit.

5. Der Geliebte ist weit weg, meine Leber (mein Herz) brennt und ist glühend heiß geworden.

6. Mein Körper ist gänzlich verbrannt. In der Sesshaftigkeit der Geduld habe ich keine Ruhe.

7. Ich lebe von meinem Geliebten getrennt, ich verberge mein Leiden, ich leide.

8. In meiner Vorstellung trat ich an die Stelle des Regenten (Sultāan Sähāa), mehr Möglichkeiten habe ich nicht.

9. Weil ich der Diener meines hochwertigen Königs (Sulțān Säḥāk) bin, rechne ich mich nicht als arm:

10. Meinem König zu dienen ist ein Schatz, neben dem ich keine Halbgoldmünze mehr brauche.

(Kälām Nr. 12)

Um die Einigung der Gläubigen mit der absoluten Wahrheit zu erzielen, lassen sich die Yārān im Jäm-Xāna von der heiligen Musik - ihrem Rhythmus, ihrer Tonhöhe und der 
Melodie selbst - in den transzendenten Zustand einführen. Das Wort „,̂̈m“ bedeutet „geeinigte Menschen“ und drückt den Sinn des Zusammenseins der Yārıstān-Gläubigen aus. Wie schmerzhaft ein Yār die Trennung vom Jäm empfindet, vergleicht der Dichter mit der Trennung eines Fisches vom Wasser oder eines Rehs von der Steppe:

1.O, Gott! Trenne bitte die Wahrheit nicht von den Freunden der Wahrheit!

2. Trenne bitte die Freunde der Wahrheit nicht vom Glauben und von der Religion!

3. O, Gott! Du bist die Blume und ich bin deine Nachtigall.

4. O, Gott! Bitte trenne die Nachtigall von der Blume nicht ab!

5. Der Teich ist die Behausung der Ente. Sie lebt ohne Teich nicht.

6. O, Gott! Trenne bitte die Ente vom Teich nicht ab!

7. Das Wasser ist die Behausung des Fisches, ohne Wasser lebt er nicht.

8. O, Gott! Trenne ihn bitte vom Wasser nicht ab.

9. Heute steht die Zypresse im Garten.

10. O, Gott! Trenne sie bitte vom Garten nicht ab.

11. Du erschaffst sowohl die Biene als auch das Wachs.

12. O, Gott! Trenne sie bitte vom Wachs nicht ab!

13. Das Reh hat die Behausung in der Steppe. Es lebt ohne Steppe nicht.

14. O, Gott! Trenne es bitte von der Steppe nicht $a b$ !

15. Der Ort des Ṭāyfa ${ }^{69}$ ist das Jäm-Xāna. Er (der Ṭāyfa-Gläubiger) lebt ohne Jäm nicht.

16. O, Gott! Trenne ihn bitte vom Jäm nicht $a b$ !

17. Quščıqlı ist der Knecht. Er kommt aus dem Dīvān (Gerichtshof Gottes).

18. O, Gott! Trenne bitte keinen deiner Knechte vom Dīvān ab! (Kälām Nr. 5)

\footnotetext{
${ }^{69}$ Ṭāyfa (arab.) ist ein anderer Name für einen Yār. Țāyfalär (Pl., türk.) heißt ,Yārān“. Ṭāyfasān (arab../ pers.) heißt „Kollektiv“" oder „Yārıstān“.
} 


\section{b) Seelenwanderung}

Unter dem Begriff „Seelenwanderung“ versteht der Yārıstān-Glauben die Wanderung der Seele nach dem Tod des Menschen von einem Körper zum anderen, mit dem Zweck sich zu reinigen, um die absolute Wahrheit erfahren zu können.

1. (Wisst ihr), Yārān, welchen Körper und welche Aufgabe ich früher hatte und für welche Aufgabe ich nun gekommen bin?

2. Vom Anfang an war ich eines, und jetzt bin ich etwas anderes, das der heutigen Aufgabe auch entspricht...

9. Mein Kopf gehört dem Binyāmīn (ich hatte Särsıpārī ), mein Beiname ist Quščığl1.

10. Durch die Seelenwanderung bin ich von einem Körper zum anderen gekommen

(Kälām Nr. 129)

Äsrār-e Yārī von Säyyed Kāżem Nīknežād erzählt, dass das grundlegende Geheimnis von Sulțān Säḥāk - das „Wahrheitsgeheimnis“ - die Seelenwanderung ist. Darüber dürfen lediglich die Yārıstān etwas erfahren, und nur die echten Yārıstān-Gläubigen werden ewig leben:

7. Die Freunde der Wahrheit (Yārıstān) hoffen auf das Wahrheitsgeheimnis.

(Kälām Nr. 44)

11. Er (Sulțān Sähāa) stellt Leben und Tod einander gegenüber:

12. Es wurde von ihm so festgelegt, dass nur die echten Freunde der Wahrheit ewig leben („Bäqā’-Xäl ‘̈tin-Kleid anziehen).

(Kälām Nr. 20)

3. Die Welten sind vergangen. Wir werden auch vergehen.

4. Nennt ihr uns nicht „Gestorbene“! Es ist eine Umgestaltung für uns. (Kälām Nr. 36)

Dem Seelenwanderungsprinzip entsprechend wird jede Seele von den Yārıstān 1001 Mal von einem Körper in einen anderen Körper wandern. Dieser Seelenwanderungsprozess wird, so Äsrār-e Yārī, ca. 50000 Jahre dauern. Während dieses langen Prozesses wird der Mensch von vielen Schwierigkeiten und Qualen betroffen und mehrmals auf die Probe gestellt: 
7. Wir hatten uns gequält, wir hatten auf diesem Wege (des Lebens in der Yāristān-Gemeinde) unser Blut geschluckt.

8. Nennt ihr uns nicht gestorben! Es ist eine Umgestaltung.

(Kälām Nr. 32)

Dadurch soll ein solches transzendentales Bewusstsein erreicht werden, dass der Mensch von der Wahrheit empfangen und aufgenommen werden kann, so dass er unsterblich wird:

39. Lasst uns die Sterblichen verlassen.

40. Wir nehmen das mit, was ewig und unsterblich ist.

41. Werft das weg, was sterblich ist, und nehmt das mit, was ewig ist,

42. Achtung! Achtung! (Der Ewige) ist der, der zweifellos ist.

(Kälām Nr. 288)

\section{c) Weltrettung durch die Yārıstān}

Die Yārıstān schreiben sich eine Weltretter-Rolle zu. Nach dem Abschluss des Seelenwanderungsprozesses werden zahlreiche Yārıstān, die schon mit Gott eins geworden sind, als die Wahrheitsträger eine Rettungsgruppe bilden. Sie sind dazu berufen, die ganze Welt zu retten:

1. Ein Anspruchsvoller steht auf dem Wege und sieht alle herausfordernd an.

2. Die Wahrheitsliebenden sind aber bitter (hässlich) geworden ...

9. Die Anderen nennen euch „Abfall““.

10. Sagt zu diesen Menschen, dass diese Abfälle jetzt Retter geworden sind.

(Kälām Nr. 296)

Die Yārıstān-Gläubigen meinen, dass die Zeit für die Welt schon vorüber ist, dass sie in den letzten Zeiten leben:

18. Es bleibt eine halbe Stunde, bis mein Herr zum Richter wird.

(Kälām Nr. 4) 
Unter den Begriffen „der Richter“, „der Gerichtshof“, „,das Gericht“ oder „das Jüngste Gericht“, die in den Texten mit einem persischen Wort „Dīvān“ ausgedruckt werden, verstehen die Yārıstān das Gericht Gottes und/oder das letzte Gericht Gottes, worin über die Menschenschicksale entschieden wird und die Welt die Perfektion erreicht:

1. Die Welt wird überall voller Freunde (Yārān) sein (an dem Tag, an dem Sulțān Sähāk erscheint).

2. Die Welt wird überall zum blühenden Blumengarten werden.

3. Gott wird sich mit seiner Großmut und Liebe an die Menschen wenden.

4. Er wird den gestorbenen Körpern das Leben geben.

$$
\text { (Kälām Nr. 33) }
$$

Es gibt in der Yārıstān-Literatur weitere Begriffe, die Bezug auf den letzten Tag der Welt nehmen. So wird unter dem ,entscheidenden Krieg“ ein Krieg zwischen den 72 Völkern der vier Weltteile (den vier Ecken der Welt) verstanden. In diesem grund- und zwecklosen Krieg werden die Yārıstān eine Retter-Rolle spielen:

5. Ein entscheidender Krieg wird in allen vier Weltteilen stattfinden.

6. Es wird so viel Blut vergossen, dass seine Flut die Leichen mitnehmen wird.

7. In der Stadt Sulțāniya werden unsittliche Könige verurteilt,

8. Und ein hohes Gericht wird über sie in der Stadt Zänĵān abgehalten.

9. Die Reiter werden sieben Tage und sieben Nächte reiten.

10. Am Tag des jüngsten Gerichts wird ein Sturm toben.

11. Die Sieben Wesen kommen zusammen auf einem ausgewählten Platz.

12. Das ist keine Lüge, es wird alles sichtbar werden.

13. Es wird aus den $72^{70}$ Pīrān eine Rettungsgruppe gewählt.

\footnotetext{
${ }^{70}$ Die Zahl 72 darf man nicht wörtlich verstehen. Sie bedeutet in der Mythologie der Yārıstān „,viel““. Zu den beliebtesten Zahlen der Yārıstān gehören außerdem z. B. die 3 (dreitägiges Mär-1 Nov-Fasten nach dem ersten Vollmond im November und ein zweites dreitägiges Qävāltās̄̄-Fasten nach dem ersten Vollmond im Dezember), die 4 (vier Engel, vier Weltecken, vier Naturelemente), die 7 (Sieben Wesen, Sieben Mächte, sieben Himmel, sieben Nächte für das Dāvātloq-Fest), die 16 (Xānıdān, Ären), die 40 (Vierzig Personen). 366 Knochen des Menschenskeletts und 444 Venen im Menschenkörper (Kälām Nr. 288). 500 Jahre lebte Gott in Havrāmān im Geheimen. 770 Jahre lang gestaltete Gott den Menschen. 90.000 Knechte (z. B. Kälām Nr. 2). 1001 Verkörperungen Gottes bzw. einer Seele (z. B. Kälām Nr. 60). 1001 Jahre für Hezār o änd - „eine glückliche Nachricht“، 400.000 Jahre war Gott in der Perle. 15 Millionen Jahre war Gott zwischen Yā-Ära und Xāvändıgārī-Ära abwesend.
} 
14. Es wird für sie eine Ehre werden.

(Kälām Nr. 33)

Eine epische Darstellung der apokalyptischen Zeiten findet sich im Kälām Nr. 96. Dieses Kälām ist ungewöhnlich groß und umfasst 94 Zeilen. Die Komposition dieses Kälāms ist offensichtlich künstlerisch festgelegt: das Gedicht beschreibt eine Vision der Zukunft mit dem Umbruch des Geschehenes genau in der Mitte des Kälāms auf der Zeile Nr. 46. Im ersten Teil werden die letzten und schlechten Jahre der Welt beschrieben:

1. Es wird eine Zeit kommen, in der die Yārān untereinander Feinde werden.

2. Kurz bevor Sulțān Sähāa erscheinen wird, kommen sehr schlechte Jahre.

3. In dieser Zeit wird es unmöglich sein, einen Feind von einem Freund zu unterscheiden.

4. Die lügenden Asketen ${ }^{71}$ werden misstrauisch werden.

5. Ehre und Scham verschwinden völlig, bis nichts davon übrig bleibt.

6. Alles, was die Leute über uns sagen, wird Verleumdung sein.

7. Feindschaft, Missverständnis und Hass von Däjj̄̄âl ${ }^{72}$ werden die Welt regieren.

8. Alles, was wahr ist, wird als Lüge betrachtet werden.

9. Gerechtigkeit und Gutmütigkeit werden aus der Welt verschwinden.

Dann kommt die Zeit für das letzte Gericht:

10. Die Waage wird aufgestellt und das Maß festgelegt.

Es wird einen Weltkrieg geben, in dem es keinen Sieger, sondern nur Verlierer geben wird. Eroberung, Verbrechen und Mord werden zum Alltag gehören.

${ }^{71}$ Gemeint sind fanatische Mullahs.

${ }^{72}$ Däĵ̄āl (arab.) bedeutet „Antichrist, der vor dem Endgericht auf einem Esel erscheint und viel Schaden anrichtet, bis der „verborgene Imam“ ihn besiegt; Schwindler, Betrüger, Usurpator“ (vgl. Junker/Alavi 1363/1984, S. 301). 
Einige Zeilen sind so formuliert, dass sie sich geradezu auf die Gegenwart zu beziehen scheinen. Sie nennen konkrete Staaten, Städte und Völker, die in den letzten Krieg einbezogen werden:

21. Eine mächtige Armee kommt aus China.

Oder:

30. Iran wird den Russen und den Türken helfen.

Oder:

41. Die Iraner werden in eine bedrängte Lage geraten.

42. Die Stadt Kırmān wird in dieser Zeit zerstört werden.

Der Umbruch der Endzeiten findet dann statt, wenn die Wahrheit endlich ihre Macht zeigt:

46. Ein heiliger Befehl wird von der Wahrheit (Gott) erteilt werden.

47. Die 7 Reiter (die Sieben Wesen) werden in dieser Zeit erscheinen.

48. Ihr Lager wird auf den Spitzen (im Himmel) aufgeschlagen.

49. Kanonen und Gewehre werden nach dem Willen der Wahrheit nicht mehr schießen.

Das Böse wird besiegt und bestraft und

66. Dann beginnt die Wunder-Ära.

Es werden nachher nur gute Menschen leben, die Ungläubigen werden bereuen. Es wird ein gerechtes Gesetz für alle gegeben. Ein glückliches Leben fängt für die Yārıstān an:

88. (...) Die Welt wird ein Paradies werden.

Die Überzeugung, dass er eine neue Chance hat, eine bessere Welt zu schaffen oder noch einmal in einem anderen Körper zu leben, verleiht einem Yār das Gefühl, die Macht über das eigene Schicksal zu haben, befreit ihn von den Ängsten vor der irdischen und auch himmlischen Zukunft. Es gibt keinen Platz für eine Rache Gottes. Die Menschen können immer ihre Taten bedenken, sich selbst und die Welt verbessern. Die Welt hat kein Ende, lautet die Botschaft dieses Kälāms.

Es bietet sich an, diese Darstellung der apokalyptischen Zeiten bei den Yārıstān mit der entsprechenden Vorstellung bei Zarathustra zu vergleichen. In beiden Religionen wird es keine letzten Zeiten geben, sondern die Welt wird erneuert. Das Böse wird in einem kosmischen Krieg besiegt (vgl. Hinnels 1975, S. 31, 106f.). 


\subsection{Die Moralprinzipien}

\section{a) Šärț und Iqrār (,der Pakt"“ und ,die Verpflichtung“)}

Beide Wörter sind grundlegende Begriffe im Yārıstān-Lexikon. „Šärṭ” und „Iqrār“ kommen häufig in verschiedenen Texten vor und heißen wörtlich „Pakt“ und „Verpflichtung“. Unter diesen Begriffen versteht man die Loyalität und die Zuverlässigkeit. Darüber hinaus bedeuten diese Wörter den Glauben ohne jeden Zweifel und die Verantwortlichkeit gegenüber allen Regeln und Prinzipien der Yārıstān und das oberste Prinzip, das Geheimnis von Yārıstān bis zum Tode zu bewahren. In diesem Zusammenhang dürfen Männer ihre Oberlippenbärte nie rasieren oder deren Form verändern.

Diejenigen, die „Šärṭ" und „Iqrār“ nicht entsprechen, sind Folgende:

- Diejenigen, die die Rechtmäßigkeit der Yārıstān-Religion anzweifeln,

- Diejenigen, die ihren Pakt brechen,

- Diejenigen, die die Geheimnisse der Yārıstān preisgeben,

- Diejenigen, die sich einem Pīr nicht unterwerfen bzw. der Zeremonie

„Särsıpārī“ (diese ist mit der christlichen Taufe und Konfirmation vergleichbar) nicht durchlaufen.

Die Vereinigung eines Yārıstān-Gläubigen mit der Wahrheit ist nur dann zu erreichen, wenn er seinen Glauben nicht bezweifelt. Der Weg zur Wahrheit wird in der Kälāmāt-1 torkī auch als der Weg nach Hause dargestellt:

13. Derjenige, der in seinem Inneren verzweifelt, erreicht sein Haus nicht.

14. Ein reines Ritual bringt den Yār nach Hause.

(Kälām Nr. 20)

Die Wahrheit hat auch ihre irdische Behausung - das Jäm. Im Jäm kann ein Yār sich mit Gott vereinigt fühlen. Um sich mit Gott eins $\mathrm{zu}$ fühlen, muss der Mensch das Grundprinzip der Yārıstān-Moral einhalten: man darf keinen Zweifel am Glauben und an der Yārıstān-Gemeinde haben:

5. Derjenige, der die Yārıstān-Moral nicht berücksichtigt, darf in dieses Jäm nicht eintreten.

6. Nur derjenige, der keinen Zweifel hat, ist in dieser 
Verkörperung ein Yār.

(Kälām Nr. 22)

Pīr Bınyāmīn ist in der Mythologie der Yārıstān der Herr von „Šärṭ“ und „Iqrārr“. Er wird als solcher auch oft in der Kälāmāt-1 torkī erwähnt:

2. Begnadige mich wegen der entstandenen Šärt und Iqrār Bınyāmīns.

(Kälām Nr. 1)

4. Mir zu verzeihen wegen des Paktes Bınyāmīns. Hilf mir! Ich schreie um Hilfe.

(Kälām Nr. 17)

3. Die den Pakt Bınyāmīns verleumden,

4. Werden zu Eseln und bekommen tierische Eigenschaften.

(Kälām Nr. 34)

\section{b) Hefz-e Äsrār („die Bewahrung der Geheimnisse der Yārıstān bis zum Tod“) und Täqyyä (,,die Verheimlichung“)}

Die Religion der Yārıstān ist auch unter einem anderen Namen, nämlich „Serr-e Mägū“ bekannt, was wörtlich „nicht erzählbares Geheimnis“ heißt. Die Yārıstān-Gläubigen dürfen über ihren Glauben in der Öffentlichkeit nichts erzählen:

5. Du hast versprochen, mein Geheimnis zu bewahren.

6. Du hast aber dein Wort nicht gehalten und mein

Geheimnis öffentlich gemacht. Es gibt außer dir viele andere, die das Geheimnis bis zum Tod bewahren.

(Kälām Nr. 13)

Dieses Verbot ist wahrscheinlich keine ursprüngliche Vorschrift in der Ordnung der Yārıstān, sondern ein Ergebnis der jahrhundertelangen Verfolgung durch die offiziellen Religionen des Mittleren Ostens mit dem Zweck, die Mitglieder der Yārıstān-Gemeinde zu vernichten. Es gab und gibt immer noch zwei Gründe für diese Verfolgungen: religiöse und politische. Die Yārıstān haben gelernt zu überleben. Ihre Überlebenstaktik heißt in der islamischen Welt Täqyyä („die Verheimlichung“‘). Die Kälāmāt-1 torkī und die Erzählungen von der Äsrār-e Yārī enthalten zahlreiche Beispiele für Täqyyä. Die MovlāȳîÄra, die ‘älī als Verkörperung Gottes anerkennt, und die Sulțān Mähmūd- 
Ära, die Sulțān Mäḥmūd als einen heiligen Helden darstellt, sind in ihrem vollen Umfang die reinen Täqyyäs.

Die islamische Begrifflichkeit wird in die zahlreichen Kälāmāt künstlich eingebaut, ohne irgendeinen Bezug auf den Inhalt des Gedichtes zu nehmen, wie es z. B. im Kälām Nr. 13 in den Zeilen 6 und 7 zu sehen ist:

6. Du hast aber dein Wort nicht gehalten und mein Geheimnis öffentlich gemacht. Es gibt außer dir viele andere, die das Geheimnis bis zum Tod bewahren.

7. Die Sonne einigte sich mit dem Mond, um die Helligkeit für Muhammad (den Propheten) zu erzeugen.

(Kälām Nr. 13)

Die islamische Begrifflichkeit wird aber auch als künstlerisches Hilfsmittel von den Dichtern verwendet, wenn sie die Unterschiede zwischen den Islamgläubigen und den Yārıstān-Anhängern verstärkt bildlich darstellen möchten:

5. Hunderte von Tausenden von Hädschis reiten die Kamele, um Mekka zu besuchen.

6. Unsere Hädschis sind zu Fuß ins Haus der Wahrheit gekommen.

7. Man geht in die Moschee, um die Wand anzubeten.

8. Das Wandgebet wird immer wieder ins Gedächtnis gerufen.

(Kälām Nr. 30)

11. Teilt ihr Muhammad mit, dass ich das Wort der Wahrheit spreche:

12. Schau dir Muhammads Anhänger an, die vom Wort der Wahrheit keine Ahnung haben.

(Kälām Nr. 15)

9. Du Quščıogl1, verlass Bäğdād nicht, begib dich nicht nach Mekka!

10. Mekka ist vom Platz aufgesprungen und ist nach Bägdād angekommen.

(Kälām Nr. 30)

Da in Bagdad Šāh Ibrāhīm lebt, so Säyyed Kāżem Nīknežād, ist diese Stadt für den Dichter dieses Kälāms, sowie auch für alle Yārıstān, wichtiger als Mekka. 
Ebenso sind die Liebesgedichte der persischen Mystiker für die Yārıstān wertvoller als das islamische Gesetz:

7. Ein echter Yār öffnet ein eigenes Heft (blickt ins eigene Herz), um das Geheimnis des Nahrungsspenders (Gottes) zu entdecken.

8. Wenn jemand dieses nicht versteht, ist er ein verderbter Asket (Mullāh oder islamischer Sufi).

(Kälām Nr. 29)

Mit dem „Heft“ bezeichnet man im Persischen eine Sammlung von Liebesgedichten sehr beliebter Dichter wie z. B. Hafiz oder Movlävī. Da das Thema der Liebe im Islam verschwiegen wird, ist es in der islamischen Gesellschaft auch heute noch nicht üblich, offen darüber zu sprechen. Dieses Kälām stammt aus dem 16. Jahrhundert (der Dichter Quščıġlı lebte in der Šāh Ismā’̂̄l Ṣäfäwī-Zeit im 16. Jh.). Bis Mitte des 20. Jahrhunderts bezeichnete die offizielle religiöse Moral diese zwei und viele andere Dichter des Mystizismus, die über die Liebe schrieben, als Ketzer. Die iranische Geschichte kennt viele Dichter, die als Mystiker zum Tode verurteilt wurden. Einer von ihnen war Mä’ṣūm `Älīšāh, der im Jahre 1212 (1833) auf Befehl von Behbähānī, dem Imam von Kermānshāh, im Fluss Qärasu ertränkt wurde (vgl. Dehkhoda 1968, Band 45, S. 733).

Mit dem Wort „Asket“ bezeichnet man in der persischen Umgangssprache die Mullāhs. Damit wird deutlich gemacht, dass die Mullāhs nur an das Gesetz denken und nicht an die tieferen Werte des Lebens. Solche und ähnliche Zeilen lassen sich als Kritik am Islam oder aber als gesellschaftliche Kritik verstehen:

3. Ich sah Mullāhs, die Theologie studierten und sich zu den Weisen rechneten.

4. Wie kann man solches Wissen zur Wissenschaft rechnen? Ist es nicht genauso, als wenn die Wahrheit und Dīvān (Gerichtshof Gottes) keine Verbindung miteinander hätten?

(Kälām Nr. 14)

7. Ich sah Mullāhs, die Theologie studierten und sich zu den Weisen rechneten.

8. Wie kann man solches Wissen zur Wissenschaft rechnen? Ist es nicht genauso, als wenn die Wahrheit vom Dīvān 
(Gerichtshof Gottes) keine Ahnung hat?

(Kälām Nr. 15)

7. Wenn jemand ein Herz glücklich macht,

8. Dann ist er schon ein Häddschi ohne nach Mekka zu gehen.

9. Die Anderen nennen euch „Abfall“.

10. Sagt zu diesen Menschen, dass diese Abfälle jetzt Retter geworden sind.

11. Die Rassen des Antichristen eroberten die Welt,

12. Sie lügen und tragen die Krone.

(Kälām Nr. 296)

Es ist den Yārıstān-Gläubigen bewusst, dass ihre Religion eigenständig ist und sich vom Islam, Judentum und Christentum unterscheidet und abgrenzt:

3. Der Koran ist keine Lüge, das schwöre ich bei Gott! Das Wort Gottes ist dafür eine Bestätigung,

4. Dass Muhammad der Prophet Gottes ist und in der Welt Wundertaten vollbringt.

5. Der Koran ist keine Lüge, er ist wahr: Universen sehnen sich nach ihm.

6. Nur einer von Tausenden ist so frech wie Mūsā (Moses), und seine Worte drücken etwas anderes aus (als die islamischen Worte).

7. Sie (die Muslime) wissen von unserer Religion gar nichts, sie beten nicht in Richtung unserer Mihrab (sie akzeptieren unsere Rituale nicht).

8. Sie gehen nicht unseren Weg, sie sind Fremde, sie haben Angst.

(Kälām Nr. 50)

Die Fremdheit in der Religion der Anderen und der Fremdenhass sind ein Hauptproblem für die Yārıstān, sowohl in geschichtlicher Hinsicht, als auch in der Moderne des Mittleren Ostens. 


\section{c) das soziale Gewissen der Gemeindemitglieder}

$\mathrm{Zu}$ einem Gemeindemitglied wird ein Yār nur nach dem bestandenen Ritual der Initiation - Särsıpārī. Auf Grund dieses Rituals verstehen sich die Yārıstān als Blutsgeschwister. Diese Blutsverwandtschaft verpflichtet sie, festgelegte Regeln in ihren Beziehungen einzuhalten. Zu den Regeln zählen:

- Ädäb o Ärkān (,Gute Umgangsformen und Fundament“).

Dieses Prinzip besagt, dass die Gemeindemitglieder einander verehren, einander lieben müssen. Es wird in der Gemeinde genau aufgepasst, dass alle Gemeindemitglieder die Prinzipien von Šärṭ und Iqrār aufrechterhalten. Im Rahmen dieses Prinzips gibt es eine große Solidarität unter den Gemeindemitgliedern.

- Ädäb o Ärkān-e Jäm („Höflichkeit und Basisregeln im Ĵ̈ä““).

Dieses Prinzip wird im Jäm beachtet. Unterwegs zum Jäm liest man flüsternd ein bestimmtes Gebet:

1. Ich schließe mich dieser Reise an, um die perlenartigen Waren zu kaufen,

2. Um den Hochmut aufzugeben, die Heuchelei abzuwerfen.

3. Ich bin ein Sklave dieses Jäms, ich gehorche allem, was es (Jäm) mir befiehlt,

4. Ich bin hierher gekommen auf Befehl Sulțān (Saḥāks), um die Hefte (Reden) zu bekommen.

5. Ich habe mich von der Habsucht losgesagt, ich habe die Reden von den Sieben Wesen übernommen,

6. Ich bin kein Tausender-Ego ${ }^{73}$, ich bin gekommen, um Weisheit zu erlangen.

7. Ich komme in die Stadt des Königs, ich flehe seinen Prüfer ${ }^{74}$ an.

8. Ich habe den Kleinwarenhandel aufgegeben (die wertlose Welt), um die edelste Perle zu kaufen (die reine Wahrheit zu erreichen).

9. Quščığlı ist ein Knecht und stellt sich unter des Sulțāns Befehl,

10. Er (Quščığl1) ist zur Kaaba (Ĵ̈ä) gekommen, um den

\footnotetext{
${ }^{73}$ Unter „Tausender-Ego“ versteht die orientalische Literatur jemanden, der sehr gierig ist und viele unangemessene Wünsche hat.

${ }^{74}$ Der Kenner, der mit dem Prüfstein das Reine vom Falschen sortiert.
} 
vollständigen Ṭävāf (Rundlauf) um sie zu vollziehen.

(Kälām Nr. 3)

In diesem Gebet sind alle grundlegenden Moralprinzipien der Yārıstān präsent: man erkennt die Wahrheit, ist rein in seinem Vorhaben, bescheiden, gehorsam und höflich. Während der Versammlung im Jäm geht man allen vorgeschriebenen Schritten des Rituals nach.

\section{- Verehrung der vier Elemente}

Yārıstān leben mit der Natur in Harmonie. Sie verehren Feuer, Erde, Wind und Wasser:

7. Wasser, Feuer, Erde und Wind sind bedeutend im Haus, wo Ordnung das Hauptprinzip ist.

(Kälām Nr. 310)

Man darf das Feuer ohne Gebet nicht löschen. Wasser wird als belebtes Element betrachtet und muss immer sauber gehalten werden. Auf die Erde darf man nicht spucken. Man darf nicht seine geschnittenen Nägel oder Haare ins Wasser werfen, sondern nur gewaschene und anschließend geschnittene Haare dürfen in der Erde, zwischen den Ruinen oder auf den alten Friedhöfen vergraben werden. Über ähnliche Verbote bei den Yeziden schreibt P. G. Kreyenbroek in "Yezidism - its background, observances and textual tradition" (vgl. Kreyenbroek 1995, S. 147-150).

\section{- Reinheit und Sauberkeit}

Yārıstān müssen auf die eigene Seele aufpassen, dass kein fremdes Element ihre Reinheit verschmutzt.

Sie halten Ihre Behausung, ihre Kleidung und ihren Körper sauber.

\section{- Familienführung}

Es gibt zahlreiche Regeln und Prinzipien in der Familienführung bei den Yārıstān. Mann und Frau kommen auf keinen Fall aus derselben Xānıdān. Sie können sowohl bei den Schwiegereltern als auch in eigenem Haus oder in eigener Wohnung leben. Es gibt keine Polygamie oder andere erlaubte, heiratsähnliche Beziehungen. Eine Scheidung, die aber sehr selten passiert, braucht keine gesellschaftliche oder gesetzmäßige Anerkennung.

\section{- Umgang mit den Kindern}

Die Kinder werden von den Yārıstān als Engel, als Nachwuchs Sultāan Sähāāss verehrt. Man darf sie beim Schlafen nicht tragen oder ihren Schlaf stören. Die Kinder werden 
nicht angeschrieen. Es gibt keine Unterschiede in der Erziehung von Mädchen oder Jungen, bis auf die Erziehung zur Religion: mit 10 Jahren dürfen Jungen zum Jäm gehen und im Kinderraum unter der Aufsicht eines jungen Pīrs alle Rituale mitmachen.

Da die Yārıstān eine der ärmsten Minderheiten in den mittelöstlichen Ländern ist, sind viele ihrer Kinder von klein an gezwungen, schwer $\mathrm{zu}$ arbeiten, um sich und ihre Familie zu ernähren.

\section{- Umgang mit den Tieren}

Die Tiere sind aus derselben Perle wie der Mensch geschaffen worden, so glauben die Yārıstān, und demnach müssen sie von den Menschen respektiert werden. Ursprünglich sind die Yārıstān Viehzüchter. Sie leben immer noch gerne mit den Tieren zusammen, sowohl in den Dörfern, als auch in den Städten. Die Seelenwanderung kann zwischen Mensch und Tier stattfinden, glauben die Yārıstān. Die Helferin Gottes Rämzbār erschien einmal im Körper des mythologischen Vogels Sīmurg. Gott selbst nahm in der Sulțān Säḥāk-Ära der Legende nach die Gestalt eines Falken und in der Yā-Ära die Gestalt eines Fisches an.

Über die Verehrung eines Fisches bei den Yārıstān habe ich von einem Pīr der ŠāhIbrāhīmī-Xānıdān namens Säyyed Ibrāhīm Säḥākī gehört. Das war in den 70er Jahren in Hamadān in einer der Dāvātloq ${ }^{75}$-Nächte. Nach dem Abendessen kam die Zeit für eine der für dieses Fest üblichen religiösen Reden. Pīr Sähāāī hatte aber dies Mal eine neue Erzählung für die Jäm-Teilnehmer vorgesehen.

Er erzählte über ein Ereignis im Dorf Polškkästa in der Nähe Hamadān, das im 19. Jh. stattfand. Die Dorfbewohner waren und sind immer noch ausnahmslos YāristānGläubige. Es war, so Säyyed Ibrāhīm Sähāāī, eine Dāvātloq-Nacht. Jääm-Diener brachten Wasser aus der Dorfquelle, um Tee zu kochen. Weil es eine dunkle Nacht war, haben sie nicht bemerkt, dass es im von ihnen geholten Wasser auch einen kleinen Fisch gab. Sie haben dieses Wasser aufgekocht und erst dann gesehen, dass ein gekochter Fisch im Wasser war. Alle Jäm-Teilnehmer waren betrübt und beweinten den Fisch. Sie spielten Tanbur und sangen Kälāmāt für den Fisch. Sie flehten Sulțān Säḥāk um Hilfe. Bei Sonnenaufgang sahen sie vor sich im Wasser einen wieder lebenden Fisch. Mit Freude brachten sie den Fisch zurück zur Quelle.

Diese Erzählung zählt nicht zu den bestätigten religiösen Reden und es gibt sie bei Säyyed Kāżem Niknežād nicht.

\footnotetext{
${ }^{75}$ Dāvātloq (,Einladung“) ist ein der Jahresfeste der Yārıstān (siehe dazu im Kapitel IV.1).
} 


\section{Zu den Relationen zwischen der religiösen Doktrin und dem praktizierten}

\section{Glauben der Yāristān}

Die Inhalte der religiösen Doktrin der Yārıstān und die Bilder, zu denen diese Inhalte in den Köpfen der Yārıstān-Gläubigen in ihrer alltäglichen Glaubenspraxis verarbeitet werden, weisen bestimmte Differenzen auf.

Es handelt sich um ein kulturelles Phänomen, nämlich um die inneren Bilder der Gläubigen. Da kulturelle Phänomene veränderlich und variabel sind, kann eine bestimmte Dynamik in ihrer Entwicklung sowohl in geschichtlicher Weise als auch in der Gegenwart in den unterschiedlichen Menschengruppen (wie z. B. Männer/Frauen, alte/junge, gebildete/ungebildete, wohl habend lebende/arme Menschen) beobachtet und beschrieben werden.

In kulturellen Imaginationen aktualisieren sich Bilder, die in kollektiven Praxen und Wissensbeständen gepflegt, entwickelt und reproduziert werden. Diese Bilder haben die Eigentümlichkeit, unvollständig und unklar zu sein (vgl. Sue, D. W. 1981). Sie stehen nur sehr selten explizit im Mittelpunkt der alltäglichen Kommunikation und machen die Aufgabe, die Imaginationen selbst und die Differenzen zwischen den Imaginationen fest zu stellen, sehr anspruchsvoll. Da diese Bilder das Kommunizieren gleichsam nebenbei und selbstverständlich beeinflussen, machen unmittelbare und dauerhafte Beobachtungen des Kommunizierens innerhalb der Yārıstān-Gemeinde und direkte Kontakte zu den Gläubigen es möglich, manche Bilder mit relativ großer Genauigkeit zu erschließen.

Die Yārıstān-Gläubigen unterscheiden in ihrer Gemeinschaft selbst zwischen sog. „warmen“ und „kalten“ Yārān. Zu den „warmen“ zählen begeisterte Gläubige, die keinerlei Zweifel an ihrem Glauben haben. Als solche sind vor allem die älteren Menschen, besonders Frauen und ungebildete Menschen zu sehen. Sie gehen mit einem Nachtgebet schlafen, wachen mit einem Morgengebet auf, ihr alltägliches Leben dreht sich um das Jäm und bezieht sich auf den Hälqueh-e Yārān ${ }^{76}$. Zu den „kalten“ Yārān zählen gemäßigte Gläubige, die sich an die Doktrin und die Ritualität der Yārıstān nicht unbedingt halten. Sie gehen außerdem selten zum Jäm. Unter solchen sieht man häufiger die jüngeren gebildeten Männer und zum Teil wohlhabend lebende Männer und Frauen wie Beamte oder Geschäftsleute. Diese Menschen stellen sich im Alltag nach außen als Sufi oder Muslime dar.

\footnotetext{
${ }^{76}$ Hälqeh-e Yārān bedeutet wörtlich „Sitzkreis der Yārıstān-Gläubigen“.
} 
Es gibt aber auch eine dritte Gruppe der Yārıstān-Gläubigen, die als „Zärädār“677 (,einen Funken Habenden“) bezeichnet werden. Einer der letzten Zärädār war Šāh Teymūr, der als Soldat der Armee von Nāser o-d-dīn-Šāh ${ }^{78}$ nach Turkmenistan geschickt wurde. Obwohl er nie früher in Turkmenistan gewesen war und nie in seinem Leben Turkmenisch gelernt hatte, sprach er plötzlich mit den Turkmenen in ihrer Sprache. Für dieses und andere Wunder war Šāh Teymūr berühmt und vom iranischen Volk geliebt. Er wurde im Jahre 1267 (1851) nach dem Befehl von Nāser o-d-dīn-Šāh und mit der Erlaubnis von Āyätollāh Behbähān̄̄ hingerichtet.

Der letzte Zärädār ist Kälāmsdichter Qäländär. Er lebte in der zweiten Hälfte des 19. Jhs. Er war ein ungebildeter Hirte im Dorf Polšekästa in der Nähe von Hamadān. Seine Kälāmāt bilden einen wertvollen Teil der Kälāmāt-1 torkī.

Unabhängig davon, zu welchen der drei Gruppen ein Yār gehört, steht die Figur von Sulțān Säḥāk im Mittelpunkt seiner religiösen Imaginationen. Sulțān Sähāak ist der Größte, der Mächtigste, der Barmherzigste. Er ist die Verkörperung der absoluten Wahrheit. Obwohl er als alter, weiser Mann mit einem weißen, langen Bart und einem netten Gesichtsausdruck von allen Yārıstān-Gläubigen imaginiert wird, wird er trotzdem immer wieder emotionell unterschiedlich erlebt. Väter und Großväter beschreiben ihn als einen traurigen alten Mann. Die jungen „warmen“ Gläubigen, vor allem Männer, sehen sein fröhliches erwachsenes Gesicht, das sie freundlich anlächelt. Die Frauen erleben Sulțān Säḥāk manchmal als einen Engel, der sie mit seinen perlenfarbigen leichten und weichen Flügeln bedeckt und beschützt. Ihrer Vorstellung nach hat er einen leichten und angenehmen Charakter und kann sie schnell fröhlich machen.

Ich habe Sulțān Säḥāk in meiner Jugendzeit als meinen eigenen Großvater gesehen. Später imaginierte ich ihn als ein ungeheuer großes hübsches Gesicht mit großen vernünftigen Augen und einem Körper, der die ganze Welt war. Sein nachdenkliches Lächeln und seine leuchtenden Augen besagten mir, dass die Welt nur ein Menschentheater ist.

Alle Yārān fühlen sich von Sulțān Säḥāk ständig beobachtet. Sie denken im Alltag an ihn und führen mit ihm einen imaginären Dialog. Wenn sie ihn laut mit den Namen „Sulțān-e Särjäm“, „Sulțān-e Ävväl-o Āxer“, „Sulțān-e Șāḥebkäräm““ anreden, werden sie von einer unbeschreiblich kalten Welle eingeholt und beginnen, unkontrollierbar zu

\footnotetext{
${ }_{77}^{77}$ G. Moradi nennt sie „Zātdār“ (vgl. Moradi 1999), was dasselbe wie „Zärädār““ bedeutet.

${ }^{78}$ Nāser-od-dīn-Šāh regierte im Iran um die Mitte des 19. Jahrhunderts.
} 
zittern. Sulțān Säḥāk macht, so die Vorstellung der Yārān, das Leben der Gläubigen erträglicher und schöner. Keine Katastrophe wird als solche empfunden, weil Alles nach dem Willen von Sulțān Sähāa geschieht und eine Prüfung für einen Yār ist, damit man sich reinigen und auf einen anderen Körper vorbereiten kann. Ein leidenschaftliches Verlangen eines Yārs ist es, von Sulțān Säḥāk Verzeihung zu erlangen.

Die nächsten Figuren sind Äzīz-Bınyāmīn (geliebter Bınyāmīn) und Güzäl-Dāvūd (hübscher Dāvūd). Diese Namen klingen für Yārān beruhigend und versprechen, dass ihre Wünsche und Hoffnungen die Ohren Sulțān Säḥāks erreichen. Der liebevolle Bınyāmīn wird als gnädiger Herr mittleren Alters dargestellt, der mit den Gläubigen zusammen zum Weinen bereit ist. Der tapfere und hübsche Dāvūd, der das blaue Pferd reitet, wird als ein starker, großer Mann gesehen. Er ist bereit, mit den Yārān zusammen sowohl $\mathrm{zu}$ weinen als auch $\mathrm{zu}$ lachen. Er ist grenzenlos freundlich und hält das Gleichgewicht zwischen dem Himmel und der Erde. Er ist Dāvūd-e Dīwān („,Dāvūd der Aufseher des Gerichtshofs"), die Verkörperung der Gerechtigkeit bei Sulțān Säḥāk. Die beiden Namen, Bınyāmīn und Dāvūd, kommen stets in den Gebeten der Yārıstān vor, besonders bei den Männern. Die Anwesenheit - im mystischen Sinne - von Bınyāmīn als dem ewigen Pīr und Dāvūd als dem ewigen Führer wird während der Zeremonien im Jäm von den Jäm-Teilnehmern immer erlebt.

Eine weitere Figur in den religiösen inneren Bildern der Yārıstān-Gläubigen ist der schweigsame Todesengel Müșṭäfā Dāvūdan. Er wird öfter von den alten Männern und Frauen mit Furcht gerufen und als ein mittelgroßer Mann mittleren Alters erlebt. Er spricht nicht, er ist ruhig und bei der Seelenwanderung behilflich. Yārān ergeben sich ihm, als dem Durchführenden des Willens von Sulțān Sähạā.

Pāk-e Rämzbār ist die einzige heilige Herrin im Yārıstān-Glauben. Sie wird von den Yārıstān-Frauen als ein Teil ihrer eigenen Persönlichkeit empfunden. Dieselben Frauen erleben Rämzbār unterschiedlich: mal als eine ältere, traditionell bekleidete und mütterlich besorgte Dame, mal aber als eine schöne schwarzhaarige kaum bekleidete junge Frau, die sich ihrer Weiblichkeit bewusst ist.

Die Anwesenheit von Rämzbār wird bei einer festlichen Mahlzubereitung besonders stark imaginiert. Es geht um die Mahlzubereitung zum "Sämänūpäzān"-Fest. Es wird dabei von mehreren (manchmal bis 80-90) Frauen gemeinsam gekocht. Vier Tage junge Weizenkeime werden in einem bis zu 300 Liter großen Topf ca. 20 Stunden lang gekocht. Die Frauen nehmen im Schichtwechsel an der Zubereitung teil. Sie erleben 
dabei, dass Rämzbār den Zubereitungsprozess beaufsichtigt und ihre Arbeit geistig unterstützt. Pāk-e Rämzbār ist für die Frauen eindeutig präsent und ihnen behilflich. Nur mit ihrer Bestätigung wird das Essen süß und lecker: dafür steckt Rämzbār am Ende der Kochzeit ihren Finger in den Brei hinein. So wird die Speise gesegnet und bereit zum Verzehr.

Es ist bei den Männern nicht üblich, an Rämzbār zu denken, und noch weniger üblich, sich darüber zu äußern. Das heißt aber nicht, dass die Männer keine Bilder von Rämzbār in ihren Köpfen haben. Rämzbār wird von ihnen sowie von den Frauen unterschiedlich erlebt: mal als eine gewöhnliche mittelaltrige traditionelle Frau, mal als eine außergewöhnlich hübsche junge Frau, mal hellhäutig mit farbigen Augen und dunkelbraunen Haar, mal aber hellbraunhäutig, schwarzäugig, schwarzhaarig und in einem himmelblauen Kleid.

Sulțān Säḥāk, Bınyāmīn, Dāvūd, Müstafa Dāvūdan und Rämzbār bilden den Kreis der beliebten Bilder, die in den Köpfen der Yārıstān-Gläubigen in ihren religiösen Praxen erzeugt, während der gemeinsamen religiösen Ritualen gepflegt und im Alltag reproduziert werden. Die Yārān erleben diese imaginierten Persönlichkeiten aktiv: sie sprechen mit ihnen, sie flehen sie um Gesundheit, Gnade und Frieden und nie um Geld oder Eigentum an. Das Aneignen bildlicher Vorstellungen von den zentralen Figuren des Yārıstān-Glaubens begünstigt bei einem Yār seine Identifizierung mit der YārıstānGemeinschaft.

Die Differenzen zwischen der dogmatischen Yārıstān-Doktrin, die von den zeitgenössischen Pīrān bestätigt wurde, und dem praktizierten Glauben zeigen sich ebenso in den rituellen Praxen der Pīrān selbst. Es werden im Jäm auch solche Predigten gehalten, deren Inhalte mit den Inhalten der Yārıstān-Doktrin keine Berührungspunkte haben.

Ich besuchte in den Jahren 1964-1969 das Jäm in der Nähe unseres Familienhauses. Der Pīr hieß Säyyed Ibrāhīm Sähākī. Er arbeitete als Postbeamter in Hamadān, lebte im Stadtteil Säng-e Šìr und war der Pīr der Šāh-Ibrāhīmī-Dynastie. Es war die Zeit des Dāvātloq-Festes. Wir saßen in einem engen Jäm-Kreis und warteten auf eine für diese Dāvātloq-Nacht vorgeschriebene Rede. Es war für mich eine große Überraschung, als ich den Anfang der Predigt gehört habe:

„Unser geliebter Movlā 'älī ging nach dem 19. Fastentag des Ramadan-Festes in die Moschee. Er beugte sich gerade im Gebet, als ein Verbrecher Namens Ebn-e Mulĵm ihn mit einem Gift gehärteten Schwert am Kopf verwundert hat. Der Mörder gehörte 
zur Xävārî̄-Gruppe ${ }^{79}$. ‘Älī war schwer verletzt. Seine Söhne, Häsän und Ḥuseyn, brachten ihn nach Hause. 'Älī sprach seine Söhne an: „Ich werde am 21. Ramadan-Tag sterben. Ihr dürft meine Leiche nicht beerdigen. Ihr nehmt meinen Sarg dorthin, wohin der Sarg sich tragen lässt. Der Sarg wird euch in die Richtung der Steppen am Rande der Stadt führen. Ihr werdet einen Araber mit verschleiertem Gesicht in Begleitung eines Kameles treffen. Der kommt, um meinen Sarg abzuholen. Er wird schweigen. Ihr müsst ebenfalls schweigen. Ihr dürft keine Frage stellen und keine Antwort verlangen. Ihr gebt meinen Sarg an ihn ab und kehrt unverzüglich nach Hause zurück“. `Älī starb am 21. Ramadan, wie er es auch vorhergesagt hatte. Seine Söhne legten ihn in einen Sarg und ließen sich vom Sarg in Richtung Steppen am Rande der Stadt Näjäf führen. Sie sahen im Staubwirbel einen Araber, der sich ihnen näherte. Sein verschleiertes Gesicht konnten sie nicht sehen. Ohne ein Wort zu sagen, nahm er ihnen den Sarg ab, band ihn auf dem Rücken des Kamels fest und machte sich für die Rückkehr bereit. Häsän und Huseyn drehten schon um, um nach Hause zu gehen, als sie sich verzweifelt anblickten. Sie sagten nichts, denn sie verstanden einander ohne zu sprechen. Sie liefen dem Araber hinterher. Sie holten ihn ein und stellten ihm die Fragen: „Wer bist du? Was hast du vor?“" Der Araber wandte sein Gesicht ab von ihnen. Er ging seinen Weg unbeeindruckt weiter. Die Brüder waren sehr aufdringlich und zwangen den Unbekannten, sich ihnen vorzustellen. Der Araber nahm den Schleier von seinem Gesicht. Die jungen Männer waren wie gelähmt. Sie starrten den „Araber“ an, der ihr Vater 'Älī, lebend und gesund, war. „Warum musstet ihr mein Geheimnis entdecken und habt mir nicht gehorcht?! Erzählt niemandem von unserem Treffen! Verratet mein Geheimnis keinem! Kehrt zurück und geht zum Stadtfriedhof. Dort werdet ihr eine neue Grabstätte sehen. Das ist mein Grab. Und das werdet ihr weiter erzählen.“

Die anwesenden Jäm-Teilnehmer waren anscheinend nicht überrascht, diese Geschichte zu hören. Sie reagierten wie sonst mit Weinen und Schreien. Alle haben `Älī, Bınyāmīn und Dāvūd laut gerufen: „Yā ‘älī, Yā äzīz Bınyāmīn, Yā Dāvūd“.

Meine Neugier war sehr groß, was für eine unerwartete und eigentlich unpassende Erzählung war diese. Ich forderte bald von meinem Lehrer Säyyed Kāżem Nīknežād eine ausführliche Aufklärung. Er meinte, dass die Yārıstān-Doktrin eine innere Dynamik habe, die solche Erzählungen auch akzeptabel mache; als eine bestätigte Predigt dürfe sie aber nicht in die Däfäter-e Kälām einbezogen werden.

\footnotetext{
${ }^{79}$ Xävārı̣̂ sind eine Gruppe von Islam-Gläubigen, die seit der ${ }^{\bullet} \ddot{A} l \overline{1}-$ Regierung (dem 1. islam. Jahrhundert) in den Ländern Iran und Irak bekannt ist.
} 
In denselben Jahren hörte ich eine andere Version derselben Predigt. Mein Vater und ich nahmen an einem Jäm im Stadtteil Muṣällā in Hamadān teil. Der Pīr der Xānäḥmädī-Xānıdān (meine Mutter gehört dieser Xānıdān an) hieß Säyyed Äḥmäd. Er war ein einfacher Bauarbeiter und konnte weder lesen noch schreiben, spielte aber sehr gut Tanbur und kannte die ganze Däftär-e Kälām seiner Dynastie auswendig. Die Versammlung im Jäm hatte irgendeinen festlichen Anlass. Der Verlauf der Predigt war mir schon bekannt. Der Unterschied traf fast am Ende der Geschichte ein: der Araber ging zu einer ausgegrabenen Stelle am Rande der Stadt. Er beerdigte die Leiche nach den islamischen Vorschriften. Die Brüder nahmen an dieser Beerdigungszeremonie ebenso teil. Dann weinten sie gemeinsam an dem Grab. Als der Araber seine Träne abwischte und den Schleier öffnete, sahen Häsän und Ḥuseyn ihren Vater `Älī lebend und gesund.

Diese Geschichte ist nicht die einzige, die im Jäm vorgetragen wird, obwohl sie von den Däfäter-e Kalam nicht anerkannt wurde. Es gibt andere nicht anerkannte Predigten, die z.B. einen örtlichen Bezug haben und deshalb nur einen begrenzten Interessentenkreis berücksichtigen können. Oder sie enthalten ein für die Yārıstān-Weltanschauung fremdes Element wie den Teufel oder Reichtum und dürfen deswegen in die Däfäter-e Kälām nicht einbezogen werden.

Die Differenzen zwischen der religiösen Doktrin der Yārıstān und dem von den Yārān praktizierten Glauben verleihen den beiden ihre besonderen Bedeutungen: während die Doktrin den Kern der Religion aufbewahrt, einen festgelegten Maßstab legitimiert und fordert, bereichert die religiöse Praxis die mystischen Erfahrungen der Gläubigen. 


\section{Die Struktur der Yārıstān-Gemeinde}

Die mystische Struktur der Yārıstān-Gemeinde kann man sich wie eine Perle vorstellen (s. Bild).

Sulțān Säḥāk bildet den Kern des perlenartigen Gebildes. Er ist aber auch in allen anderen Elementen der Struktur präsent. Seinen Funken erteilt er an die „Dreier“ Binyāmīn, Dāvūd und Mūsī. Diese drei und später Rämzbār sind die vier Engel. Die vier Engel mit Müsțafāă, Yādıgār und Sulțān Säḥāk bilden die Häftän (Sieben Wesen). Diese Sieben Wesen sind für die himmlischen Angelegenheiten verantwortlich. Ihre sieben Verkörperungen - Häftävān (Sieben Mächte) - sind für die irdischen Aufgaben zuständig: Säyyed Muhammad Sūr, Säyyed Bulväfā, Mīr Sūr, Säyyed Müșțäfã, Šeyx Šähāb-od-dīn, Šeyx Ḥäbīb Šäh, Ḥājī̉ābā 'Īsā.

Der nächste Ring der mystischen Struktur gehört dem ersten Jäm mit den 40 Teilnehmern. Dieses Ĵäm zu veranstalten, war die wichtigste Aufgabe Dāvūds.

Der letzte Ring der perlenartigen Struktur gehört den 72 Pīrān. Diese 72 Pīrān waren zunächst die ersten Schüler und Anhänger von Sulțān Sähāā. Später wurden einige von ihnen zu den Xānıdān-Führern ernannt.

Dieses Gebilde ist von 90.000 Knechten umrahmt. Unter den sog. 90.000 Knechten versteht man die Yārıstān-Gemeinde.

Die Gemeinde hat eine andere - soziale - Struktur. Sie besteht aus den kleinsten sozialen Einheiten - den Familien. Diese Familien sind durch die Särsıpārī (Initiation) einer Xānıdān unterordnet.

16 Xānıdān bilden die ganze Yārıstān-Gemeinde. Nach Angaben von G. Moradi gibt es 11 Xānıdān (vgl. Moradi 1999, S. 145). S. Safizadeh nennt ebenfalls 11 Xānıdān (vgl. Safizadeh 1997 b, S. 24f.). Nach einer mündlichen Mitteilung von Säyyed Kāżem Nīknežād gibt es 16 Xānıdān:
1. Šāh Ibrāhīmī
5. Mīr Sūrī
9. Ātäšbeygī
13. Säyyed Bolväfã
2. Yādıgārī
6. Säyyed Müștäfā
10. Šāh Häyāsī
14. Dāvūd Quli
3. Xāmūšš
7. Ḥâjî̄ Bābūsīn
11. Bābā Ḥeydärī
15. Juneydī
4. `Ālī Qäländärī
8. Zonnūrī
12. Xān Äḥmädī
16. Säyyed Ḥäbīb Šāh 

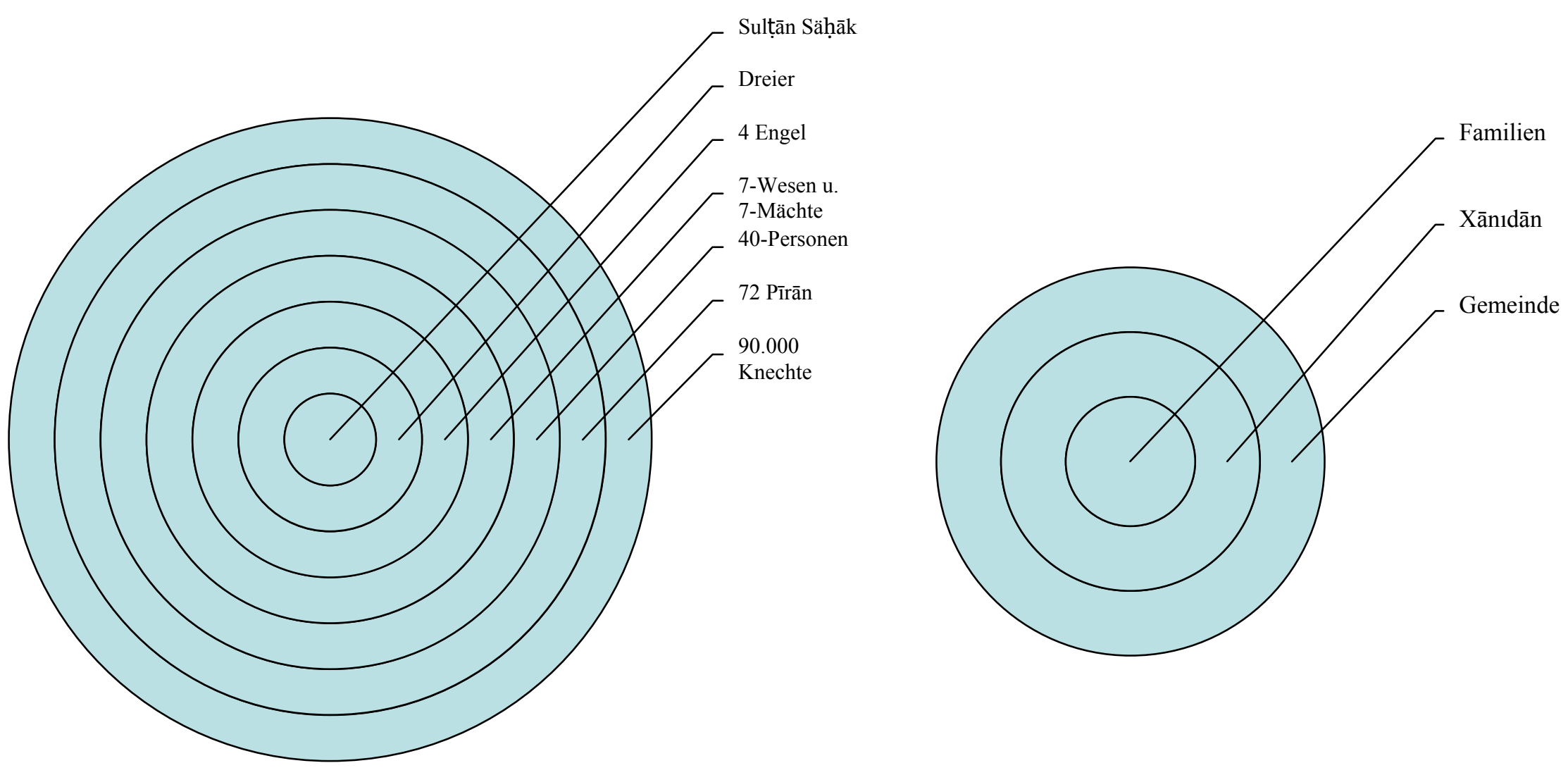

Die mystische Struktur der Yārıstān-Gemeinde kann man sich als eine Perle vorstellen.

Die Gemeinde hat eine soziale Struktur: Sie besteht aus den kleinsten sozialen Einheiten - den Familien. 
Um eine neue Familie gründen zu dürfen, müssen die zukünftigen Eheleute unbedingt aus unterschiedlichen Xānıdān stammen. Es gibt aber Ausnahmefälle, wenn sich junge Menschen aus derselben Xānıdān ineinander verlieben und heiraten wollen. Im Prinzip ist dieses zwar nicht erlaubt, wird aber seitens der Gemeindemitglieder toleriert.

Wenn die Yārıstān außerhalb der Gemeinde einen zukünftigen Ehepartner gewählt haben, wird es ihnen nicht verboten, denjenigen zu heiraten. Es wird willkommen geheißen, wenn sich ein neues Mitglied der Gemeinde anschließt. Das neue Mitglied heißt dann „der den wahren Weg Betretende“. Anders herum, wenn eines der Gemeindemitglieder die Gemeinde verlassen will, um den Angehörigen einer anderen Religion $\mathrm{zu}$ heiraten und dessen Glauben $\mathrm{zu}$ übernehmen, wird das seitens der Gemeinde ebenfalls freundlich und tolerant hingenommen. Wenn sich aber jemand im Laufe der Zeit entscheidet, in die Gemeinde zurück zu kehren, wird seine Entscheidung begrüßt:

3. Niemand darf einen anderen zwingen und sagen: komm, werde ein Freund (der Wahrheit)!

4. In die Behausung der Freundschaft soll man mit Liebe und eigenem Willen kommen.

(Kälām Nr. 30)

Jedes Mal - für ein neues Mitglied oder für einen Rückkehrer - wird eine Särsıpārī durchgeführt.

Die Kinder, die durch die Heirat zweier Angehörigen unterschiedlicher Dynastien auf die Welt kommen, gehören der Xānıdān des Vaters an. Die Konfession des Kindes, das durch die Heirat eines Angehörigen der Yārıstān mit einem anders Gläubigen auf die Welt kommt, wird allein von den Eltern gewählt oder dem Kind, wenn es erwachsen ist, selbst überlassen. Diese Regeln sind in keinem Kapitel der Yārıstān-Lehre erwähnt, werden aber als Moralprinzipien innerhalb der Gemeinde tradiert.

Dasselbe gilt für den Xānıdān-Führer. Dafür gibt es eine Vorgehensweise, die innerhalb der Yārıstān als Tradition gilt. Die Entscheidung über das nächste Sippenoberhaupt obliegt allein dem bisherigen Xānıdān-Führer. Er wählt einen Mann aus seiner Familie, der seiner Meinung nach einen Funken von Sulțān Sähāa in sich trägt. Derjenige kann einer seiner Söhne oder einer seiner Enkelsöhne oder aber auch einer seiner Brüder oder Neffen sein. 
Das Zusammensein spielt im Leben der Gemeinde eine wichtige Rolle. Die Yārıstān versammeln sich im Jäm-Xāna. In demselben Jäm treffen sich gleichzeitig die Angehörigen unterschiedlicher Xānıdān, die in der Nähe des Jäms wohnen oder sich zu diesem Zeitpunkt in seiner Nähe aufhalten.

An jedem Donnerstagabend wird das Jäm für die Gläubigen geöffnet. Ihre Teilnahme ist allerdings freiwillig. Ein Pīr ist gleichzeitig ein „Priester“, ein Lehrer, ein Führer der Versammlung im Jäm, ein Sachverständiger über sämtliche Rituale und Zeremonien, einer, der die Kälāmāt auswendig kann. Er führt ein Familienleben wie alle anderen Yārıstān-Gläubigen. Er hat einen weltlichen Beruf und lebt von seinem eigenen Einkommen. Die wichtigste Funktion eines Pōrs ist die Yārıstān-Zeremonie für die neugeborenen Yārıstānkinder - Särsıpārī (Initiation).

Der Rang eines Pīrs wird vom Vater an den Sohn weitergegeben, wenn er bestimmten Anforderungen entspricht.

Außer dem Pīr gibt es im Jäm freiwillige Diener, die sowohl die regelmäßigen Versammlungen als auch die Rituale und Feste unter der Führung des Pīrs vor- und nachbereiten. Ihre Tätigkeit wird nicht entgeltlich ausgeübt, sondern von den JämTeilnehmern als eine gute Tat angesehen. Eine schwerwiegende Aufgabe hat der Xādım (oder Xälīfa): er ist vor allem für die Durchführung der Opfer-Rituale verantwortlich. Seine weitere Aufgabe ist die zeremonielle Verteilung der Speisen während aller Veranstaltungen im Jäm. Der Xādım hat zwei Helfer, die ihm während aller Veranstaltungen helfen. Zu ihren Aufgaben gehört es z. B. auch, die Jäm-Teilnehmer über eine bevorstehende Versammlung zu benachrichtigen oder das Essen nach der Versammlung für die Abwesenden nach Hause zu liefern.

Es gibt freiwillige Dienerinnen, die im Jäm den Boden fegen und wischen, nach dem Essen das Geschirr spülen, das Fleisch von den Opfertieren zubereiten. Ihre Dienste widmen sie Rämzbār.

Andere Jäm-Teilnehmer bieten ihre Dienste dem Jäm auch an, wenn es um einmalige Aufgaben geht, wie z. B. Brennholz oder Wasser holen, Einkäufe erledigen, bei der Renovierung des Jäm-Xānas helfen.

Das Gebilde von sozialen und religiösen Strukturen innerhalb der Yārıstān-Gemeinde bleibt nur dank einer entwickelten religiösen Lehre in Form autorisierter Literatur, die von der älteren Generation der Yārıstān-Gläubigen an die jüngere Generation mündlich weiter gegeben wird, bestehen. Diese Literatur heißt in der hier behandelten türkischen Mundart die Kälāmāt-1 torkī und wurde von 24 türkischen Dichtern gedichtet. Alle 
Dichter sind namentlich bekannt. Zehn von ihnen wurden im Kälām Nr. 62 aufgelistet. Die weiteren Namen der Dichter finden sich jeweils am Ende jedes Kälāms: das entspricht der Ghasel-Form, in der alle Kälāmāt gedichtet worden sind. Die Namen sind:
1. Quščı̇̉ìn
13. Qänbär
2. Qulogil1
14. Ämīr
3. Šähsävāroğl1
15. Yādigār
4. Nämāma
16. Qäländär
5. Yūnis
17. Qāsım
6. Turābī
18. Aqaoġl1
7. Budag
19. Ovlıbābā
8. Šeyxî̄̄ān
20. Äḥmäd
9. Fätḥ̄i
21. Mäḥmūdoğl1
10. Xästäh `Ālī
22. Mäzīdog̉l1
11. Gündüz
23. Häsän
12. Quli
24. Qul Välī

Einige der Dichter sind professionelle Dichter, die auch weltliche Werke geschrieben haben. Manche sind lediglich durch ihre Kälāms bekannt.

Alle Dichter tragen den hohen Titel „Häẓrät“ („Heiliger“), den für gewöhnlich die Sieben Wesen tragen. 


\section{Rituale und Bräuche}

Der Oberbegriff für sämtliche Rituale der Yārıstān-Gemeinde heißt Kırdār (,Gute Tat“"). Alle Rituale können in drei Gruppen aufgeteilt werden: X1dmät („Dienen“), Xeyr (,Güte") und Nyāz (,,Verlangen“).

- Xıdmät - sind die obligatorischen, jährlichen Rituale, die von allen Mitgliedern der Yārıstān-Gemeinde die Teilnahme verlangen.

- Xeyr - sind Bräuche, die im Jäm oder zuhause ausgeübt werden. Sie beziehen sich auf die persönlichen Bitten der Gläubigen.

- Nyāz - sind regelmäßige Bräuche, die sich zeitlich auf den Donnerstagabend beziehen, weil die regelmäßigen Versammlungen im Jäm-Xāna immer donnerstags stattfinden. Dazu zählt auch die Norūz-Nacht.

Die Yārıstān wissen, an welchen Tagen die Rituale veranstaltet werden. Sie werden trotzdem von einem Jäm-Diener im Voraus darüber benachrichtigt. Die Veranstaltungen beginnen in der Regel um 18 Uhr und dauern durchschnittlich vier Stunden. Jeder Schritt eines Rituals, von Anfang bis Ende, wird mit entsprechenden Gebeten bzw. Gedichten aus der Kälāmāt begleitet, die jeder Gläubige auswendig kennt und leise für sich selbst ausspricht.

Mit Musik wird nur ein einziges Fest obligatorisch begleitet - das Dāvātloq-Fest.

Außer diesen Ritualen, die im Dienste der Gemeinde stehen, gibt es Rituale, die sich nur auf das Familiengeschehen beziehen: die Namensgebung, Särsıpārī (die Initiation), die Hochzeit, die Beerdigung. 


\section{Jahresfeste}

- Xıdmät- 1 Bähāra

(,Frühlingsdienen“)

-X1dmät-1 Tābıstāna

(,sommerliches

Dienen")

\footnotetext{
- Xärmän-tozī (,Staub der Ernte")
}

findet $3 \mathrm{Mal}$ im Frühling jeweils am Monatsende statt

findet $3 \mathrm{Mal}$ im Sommer jeweils am Monatsende statt

findet in der ersten

Septemberwoche statt

\section{Xidmät (,Dienen“6)}

mit dem Ziel, das Vieh (Kühe, Schafe, Es wird Milchreis gekocht, ins Jäm gebracht Ziegen und Kamele) zu würdigen. Es wird und dort unter den Männern verteilt (die darum gebetet, dass Gott das Vieh Frauen entnehmen ihren Anteil vom Milchreis beschützt. zuhause).

Es werden Gebete gelesen, der Pīr hält Reden.

mit dem Ziel, die Ernte zu würdigen. Es Es wird Tärhälvā (aus Weizenmehl und wird darum gebetet, dass die Felder, die Weintraubensaftkonzentrat) und Härīseh (aus Obstbäume und die Weinberge fruchtbar Weizenkernen, Fleisch und Weintraubensaftund gesund bleiben. konzentrat) gekocht und ins Jäm gebracht. Es werden Gebete gelesen, der Pīr hält Reden.

mit dem Ziel, den Nachwuchs der Haustiere Es wird ein Hahn bei jedem Yārıstānund die landwirtschaftlichen Erzeugnisse zu Angehörigen zuhause von einem Jäm-Diener, würdigen. Es wird darum gebetet, dass sie der dafür zuständig ist, und ein zugelassenes fruchtbar und gesund bleiben.
Messer hat, geopfert, mit Pilov (Reisbeilage) zubereitet und ins Jäm gebracht.

Es werden Gebete gelesen, der Pīr hält Reden. 
- Qurbānloq („Opfer“) findet im November bzw. Dezember statt

- Aibašı („Neumond“) findet am Neumond vor dem 22. Dezember statt

\footnotetext{
- Dāvātloq (,Einladung“"):

- Qoly,

- Š̈ähābo-d-dīn,

- Š̄ākeh,

- Š̃ānäżär,

- 'Isā,

- Š̄āhmurād,

- Pīr-e Dilāvär;

- $\quad$ Eyd-e Šāhī (Königsfest)
}

findet im Dezember bzw. Januar statt. Fängt zwei Tage nach Vollmond an und dauert 7 Tage. Am Vollmondtag beginnt das 3-tägige Fasten.
Der Höhepunkt des
Dāvātloqs ist das

mit dem Ziel, alle Haustiere und das Vieh $\mathrm{zu}$ würdigen. Es wird darum gebetet, dass alle Haustiere fruchtbar und gesund bleiben.

\section{.} für die Speisenverteilung im Jäm zuständig ist, geschlachtet, zerlegt und im großen Qäzqan (Kessel) zubereitet. Die Zubereitung wird Frauen überlassen.

Es werden Gebete gelesen, der Pīr hält Reden.

mit dem Ziel, sich emotionell auf das Fest Es wird Pilov (Reisbeilage) mit Butter „Dāvātloq“ vorzubereiten. zubereitet und zum Jäm gebracht.

Es werden Gebete gelesen, der Pīr hält Reden. In dieser Nacht wird das Fest Dāvātloq begrüßt.

mit dem Ziel, sich mit Gott und der Wahrheit zu vereinigen.
Die Veranstaltungen im Jäm finden 7 Nächte lang statt. Es wird gemeinsam Pilov mit Butter gegessen.

Es wird in Begleitung eines Tanbur gesungen und geklatscht.

In diesen sieben Nächten wird vom Pīr über die Geschichte der Yārān-i Qävālțāsī (Qoly, Šähāb-od-dīn, Šākeh, Šānäżär, 'Isā, Šāhmurād, Pīr-e Dilāvär) erzählt. 
Königsfest; es beginnt

schon in der 7. Nacht und

dauert bis zum früh

Morgen des ahcten Tags.

- Aibašı („Neumond“) findet am Neumond nach dem Dāvātloq statt mit dem Ziel, den vergangenen heiligen Monat feierlich abzuschließen.
Es wird Pilov mit Butter zubereitet und zum Jäm gebracht.

Es werden Gebete gelesen, der Pīr hält Reden. In dieser Nacht wird Abschied von dem vergangenen Jahr genommen und das neue vom Pīr begrüßt.

\section{Xeyr (,Güte“)}

- das Tieropfer

- das Verteilen des Sājâara

- das Verteilen des Säbära hat zum Ziel, sich bei Gott entweder für ein Geschehen (wie z. B. die Geburt eines Kindes, die Gesundung, das neugebaute Haus, die bevorstehende Heirat) zu bedanken oder um die Erfüllung eines Wunsches zu bitten.

wird mit demselben Ziel wie das Tieropfer zelebriert.

wird mit demselben Ziel wie das Tieropfer dargebracht.
Ein männliches Vieh oder auch ein Hahn oder Granatäpfel werden im Jäm geopfert und zeremoniell unter den JämTeilnehmern verteilt.

Es wird Sājāara (aus Weizenmehl, frischer Butter und Milch) in Form eines großen Fladen zuhause gebacken und zeremoniell unter den Jäm-Teilnehmern verteilt.

Es wird Säbära (aus gebratenem Weizenmehl mit Butter und Kräutern) zuhause eingerührt und zeremoniell unter den JämTeilnehmern verteilt. 
- das Verteilen von

Früchten und

Süßigkeiten

- das Verteilen von Süßigkeiten am

Donnerstag

- das Verteilen von Süßigkeiten am

Freitag

das Verteilen von Süßigkeiten und Rosenwasser am Norūz wird mit demselben Ziel wie das Tieropfer gemacht.

Dieses Verteilen wird im Jäm während der unterschiedlichen Zeremonien als ein Bestandteil derselben durchgeführt.

\section{Nyāz (,,Verlangen“")}

mit dem Ziel, das Zusammensein zu genießen.

Das Naschwerk wird während der Versammlung zeremoniell an die Anwesenden verteilt.

Ein Teil davon wird zurückgelegt, um später für die Abwesenden nach Hause mitgenommen zu werden.

Dabei werden Gebete gelesen.

mit dem Ziel, einen gestellten und angenommenen Heiratsantrag der Öffentlichkeit bekannt zu geben.

mit dem Ziel, am ersten Frühlingstag (das nationale iranische Neujahrsfest) einander und dem Pīr zu gratulieren.
Es werden die nächsten Verwandten und Freunde ins Jäm eingeladen. Häufig kommen aber nur die beiden Heiratskandidaten zum Pīr und bringen die süßen Gaben mit.

Dabei werden Gebete gelesen.

Alle Jäm-Teilnehmer kommen ins Jäm und bringen ihre süßen Gaben mit.

Dabei werden Gebete gelesen. 
Das wichtigste Ritual heißt auf Türkisch „Dāvātloq“ und bedeutet „Einladung“. Dies Dāvātloq ist ein jährliches achttägiges Ritual, ein willkommenes Zusammensein für alle Yārıstān-Gläubigen.

Dieses Fest ist eine Erinnerung an ein Ereignis in der Sulțān Säḥāk-Ära (s. Kapitel I.1.). Sieben ehrliche Yārān - Qoly, Šähāb-od-dīn, Šākeh, Šānäżär, 'Isāa Šāh Murād, P̄̄r-e D1lāvär - waren zu Sultān Sähāk unterwegs. Ihr Weg führte sie über den Berg Šāhū. Auf dem Berg waren sie starkem Wind und Schneefall ausgesetzt und starben. Die Sieben Wesen baten Sulțān Säḥāk, diese Menschen wiederzubeleben. Drei Tage später belebte Sulțān Säḥāk die Sieben, die seitdem Qävāltāsī-Yārān heißen.

Das Dāvātloq beginnt zwei Tage vor dem Vollmond nach dem 22. Dezember und dauert 7 Tage, die jeweils mit den Namen der Qävāltāsī-Yārān benannt wurden.

Die Vorbereitung des Dāvātloqs beginnt schon früher, mit der ersten Aibašı-Nacht (s.o.) und wird mit der nächsten Aibašı-Nacht (s.o.) beendet. D. h., dass das Dāvātloq-Fest nach dem Mondkalender insgesamt einen Monat dauert.

Alle Mitglieder der Yārıstān-Gemeinde kümmern sich in diesem Monat besonders aufmerksam um die Reinheit ihrer Gedanken und um die Sauberkeit ihrer Körper und Häuser. Das Essen und die Süßigkeiten, die für das Jäm zubereitet oder besorgt werden, dürfen nicht vorher berührt werden. Nur die Hausfrauen, die sich nach den Vorschriften gesäubert haben, dürfen sie zubereiten und einpacken. Das Essen wird bis $18 \mathrm{Uhr}$ zubereitet. Nach den Vorschriften bekleidete Männer jeder Yārıstān-Familie, die während der neun Nächte an Versammlungen im Jäm-Xāna teilnehmen, bringen dieses Essen um 18 Uhr ins Jäm mit. Es besteht aus Brot, einem großen Teller Reis, eventuell mit einem hausgezüchteten, gekochten Hahn. Das Essen wird im Jäm in einen großen Behälter aus Keramik gegeben, miteinander vermischt und dann verteilt. Das Gewicht des gesamten Essens in diesem Behälter erreicht manchmal bis zu 200 Kilogramm. Männer essen gemeinsam im Jäm und bringen einen Teil des Essens später für ihre Frauen, Mütter, Töchter und kleinen Söhne nach Hause mit.

Während die Männer ins Jäm unterwegs sind, flüstern sie ein Gebet (siehe Kälām Nr.3). Sie treten ins Jäm, verbeugen sich vor dem Jäm und sagen: „Däst-e Jäm“ („Hand des Jäms“"). Der P̄̄r und die anderen Anwesenden antworten: „Däst-e Ĵäm“. Der Angekommene küsst die Hand des Pīrs und der Pīr küsst seine Hand zurück.

Die Sitzordnung im Jäm stellt einen Kreis dar. Alle Jäm-Teilnehmer sitzen die ganze Zeit auf ihren Fersen. Der Pīr sitzt auf einem bestimmten Platz auch auf seinen Fersen. Links neben ihm sitzt der Xādım. Die Schüssel mit dem Essen steht vor dem Xādım. 

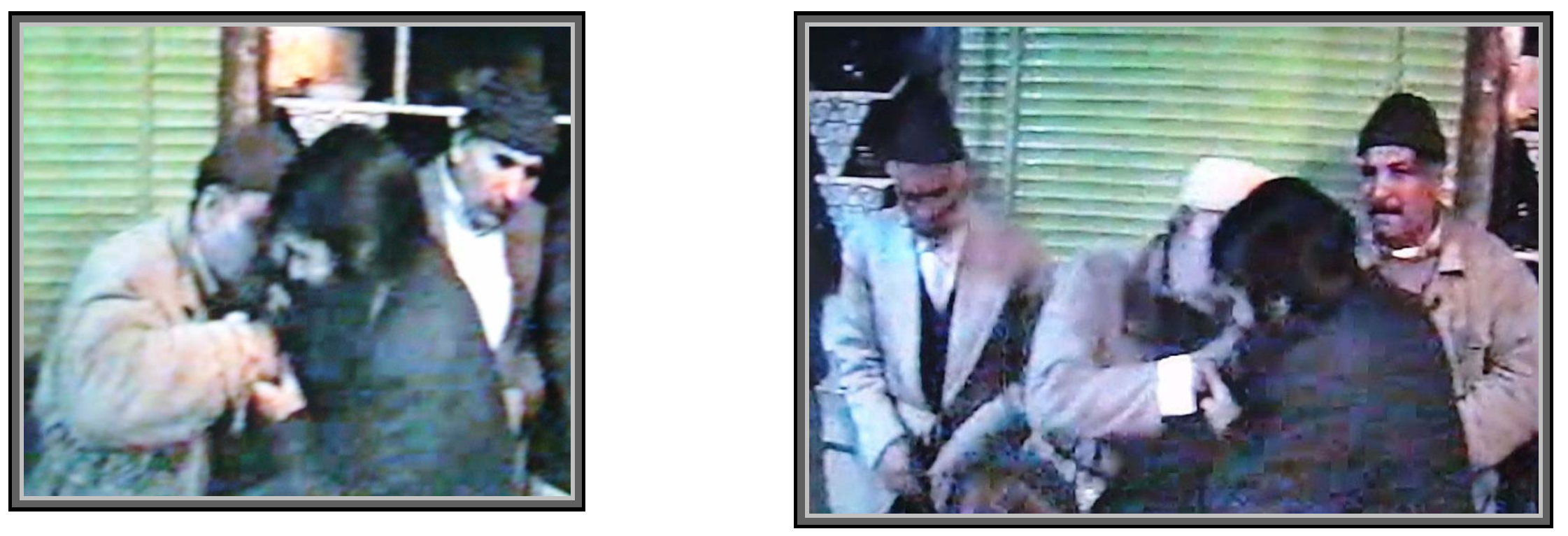

Der im Jäm Angekommene küsst die Hand des Pīrs und der Pīr küsst seine Hand zurück (aus einer privaten Videoaufnahme). 
Das Essen wird später von ihm verteilt. Rechts neben dem Pīr setzt sich derjenige, der als erster im Jäm eingetroffen ist. An der Eingangstür stehen zwei Jäm-Diener, die später, während der Zeremonie, die Jäm-Teilnehmer bedienen werden.

Wenn alle Jäm-Teilnehmer angekommen sind, begrüßt der Pīr die Versammlung: „Dīdār gördux šād oldux“ („Wir haben einander getroffen, wir sind fröhlich“). Jede Jäm-Versammlung hat ein Leitthema, und dieses Thema wird vom Pīr zur Sprache gebracht. Wenn seine Rede beendet ist, singt er die entsprechenden Kälāmāt in Begleitung vom Tanbur vor.

Danach beginnt das Abendessen. Die Diener bringen Wasserkannen und frische Handtücher für alle Anwesenden, damit sie sich die Hände waschen können. Dabei wird von den Dienern ein Gebet gelesen. Es wird eine Bodendecke aufgelegt. Das Brot und das Essen werden verteilt. Vor dem Essen tragen die Diener noch ein Gebet vor. Der Pīr liest auch ein Gebet, das mit einem gemeinsamen „Amen“ abgeschlossen wird. Jetzt darf gegessen werden. Am Ende des Mahls sprechen die Diener und der Pīr ein weiteres Gebet. Die Bodendecke wird beiseite gelegt.

Eine große Kupferschüssel voll Wasser wird in den Raum gebracht. Der Pīr trinkt als erster aus dieser Schüssel, welche die Ṭäšār-Quelle symbolisiert. Alle Jäm-Teilnehmer trinken nacheinander. Die Diener trinken als letzte aus der Schüssel. Während des Trinkens werden Gebete gelesen. Danach wird Nyāz (Süßigkeiten) herumgereicht. Am Ende werden nochmals die Hände gewaschen.

Dann ist die Zeit für eine Rede. In der ersten Dāvātloq-Nacht fängt gewöhnlich diese Rede mit dem folgenden Kälām an:

1. In deinem Schicksalsbuch steht, dass du einen glücklichen Kopf hast!

2. Mein Herz brennt in feurigen Seufzern. Schau dir die flammende Liebe an.

3. Gott schickte seine Verse, um hübsche Gesichter zu beschreiben.

4. Wie kann ein Vers Gottes falsch verstanden werden? Wenn einer so tut, ist er ein Betrüger. Pass auf, dass du nicht zu einem solchen wirst.

5. Du hast versprochen, mein Geheimnis zu bewahren.

6. Du hast aber dein Wort nicht gehalten und mein Geheimnis öffentlich gemacht. Es gibt neben dir viele andere, die das Geheimnis bis zum Tod bewahren. 
7. Die Sonne vereinigte sich mit dem Mond, um Helligkeit für Mohammad (den Propheten) zu erzeugen.

8. Guck auf die Augenbrauen in deinem Gesicht, die dem neuen Mond ähneln.

9. Ich habe von einem Fremden etwas erfahren, was heute mein Herz berührte.

10. Aus meinen Augen fließen Tränen wie der Oxus. Sieh diese unendlichen Tränen.

11. Komm an! Oh, du hoch gebildeter Meister, du bist solch ein Künstler, der

12. Aus umgestülptem Lasurstein die Welt begründet hat. Sieh dir den Maler (Schöpfer der Welt) an.

13. Die ärmsten der Heiden, Christen und Juden kommen zu mir.

14. Sei das Herz eines Gegners verblutet. Sieh dir den nicht schmelzenden Stein (das Herz eines Gegners ist gefühllos wie ein Stein) an.

15. Wenn jemand aus demselben Becher trinkt, aus dem auch Quščioġlı Wein trank,

16. Wird sein Leben unvergänglich. Sieh dir das unendliche Lebensalter an.

(Kälām Nr. 13)

Anschließend singt der Pīr nochmals entsprechende Kälāmāt in Begleitung des Tanburs vor.

In der letzten Dāvātloq-Nacht wird gewöhnlich ein anderes Kälām vorgesungen:

1. Vernachlässige deine Rituale nicht. Der König der Welt kommt zu dir.

2. Flehe am Tag und in der Nacht. Er schenkt dir die Aufmerksamkeit in Barmherzigkeit.

3. Fürchte dich vor niemandem. Er erschafft aus dem Nichtsein die Existenz und aus der Existenz erschafft er das Nichtsein.

4. Wenn der König will, erschafft er den Frühling aus dem Winter.

5. Die Opferbereiten (Yārān) kommen aus der Siedlung der Sieben Wesen und stehen auf dem Schlachtfeld.

6. Diejenigen, die auf diesem Weg sind, sind aufrichtig, sie schenken 
ihre Köpfe und ihr Leben dem König der Welt.

7. Er (der König der Welt) vereinigt den Zeitfluss mit einem bestimmten Zeitpunkt zu einem versprochenen Termin, wenn der Mond und die Sonne einander erreichen.

8. Er nimmt die Schleier von seinem Gesicht und erhellt die Nacht zum Tag.

9. Derjenige, der sich zur Wahrheit bekennt, verliert das Ansehen in der Gesellschaft.

10. Dieser Yār betet zum Galgen wie Mänșūr und auf diesem Wege bekommt er seinen Anteil vom König.

11. Es gibt diejenigen, die die Kaaba ruinieren, und so zerstören sie ihre eigene Existenz.

12. Es gibt aber diejenigen, die ihrer Wahrheit von Angesicht zu Angesicht begegnen und ihre Rituale vollziehen.

13. Es gibt jemanden, der nach der Wahrheit sucht wie ein Schmetterling, der sein Leben dem Feuer schenkt (opfert).

14. Wenn solch ein Mensch von Schwierigkeiten betroffen wird, ruft er nach Hilfe an der Tür des Pīrs.

15. Derjenige, der den Pakt Bınyāmīns verachtet und seinen eigenen Weg geht,

16. Wird gewiss vor dem Gericht des geliebten Xāvändıgār stehen.

17. Eine Nachricht kam vom König. Quščioġl1, lauf hinaus und verbreite diese Nachricht:

18. Mein Herr kommt und aus seiner Großmütigkeit enthüllt er sein Gesicht.

(Kälām Nr. 48)

In den Dāvātloq-Nächten findet manchmal eine Feuer-Zeremonie statt. Sie beginnt spontan. Das Kälām-Singen und das Klatschen im 2/4-Takt Rhythmus führt die Gläubigen in einen transzendenten Zustand. Manche erleben diesen Zustand so intensiv, dass sie die Kontrolle über ihr Bewusstsein verlieren. Sie bewegen sich, immer noch auf den Knien, in Richtung des Feuers, das in der Mitte des Jäms angelegt ist, sie treten ins Feuer, sie nehmen glühende Kohle in ihre Hände und schlucken sogar Feuer. Sie werden dabei nicht verwundet. Wenn einer die Feuerprobe nicht übersteht, wird er als einer betrachtet, der sich für die Wahrheit nicht eignet. 
Das Feiern dauert im Dāvātloq bis um 2 Uhr Nachts. Mit dem Abschlussgebet wird voneinander Abschied genommen.

Im Anschluss an den ersten Vollmond nach dem 22. Dezember findet das dreitägige Fasten statt. Dieses Fasten geschieht zum Gedenken an die drei Tage, an denen die Qävāltāsī-Yārān im Berg Šāhū durch Wind und Schneefall starben.

Drei Tage später belebte Sulțān Sähāa unter einer Schüssel aus Schneeflocken die Qävāltāsī-Yārān. So spricht die Kälāmāt-1 torkī über das Drei-Tage-Fasten:

1. Kommt, Yārān, das Kälām und die Hefte sind bei mir.

2. Öffnet eure Augen: die Quelle von Perlen ist bei mir.

3. Drei Fasten-Tage sind der Teil von Qävālțās.

4. Es sind sieben Nächte von Xıdmät, und Xıdmät selbst ist bei mir.

5. Es wurde dem Bınyāmīn befohlen, das Xıdmät zu verteilen.

(Kälām Nr. 92)

Während dieses Fastens ist es verboten, am Tag zu essen und zu trinken. Erst nach Sonnenuntergang wird gegessen und getrunken. In den Fasten-Nächten wird jede Nacht zwischen 2 und 3 Uhr im Familienkreis gemeinsam ein Gebet $^{80}$ gelesen:

1. sähär oroĵ tutaram Qävālțās-Yārānlärin 1. Ich faste früh aus Liebe zu

'1šqinäh

2. Pīr-Bınyāmīnin Šärțeynän

3. Dāvūdin rıẓāseynän

4. P̄̄r-Mūsīnin qälämeynän

5. Pāk-1 Rämzārin Kırdāreynän

6. orộıni män tutaram bayramıni

Pādišāh-1 e āläm oz buyurdoqeynän.

7. ävvälım Yār āxırım Yār

8. ḥukm-1 äzīz Xāvändıgār

\section{Qävālțās-Yārān}

2. Und entsprechend dem Pakt Bınyāmīns,

3. Zur Zufriedenheit Dāvūds,

4. Mit der Feder von Pīr Mūsī,

5. Mit der Tat der heiligen Rämzbār.

6. Ich faste selbst und das Fest ist vom

König der Welt, unter seinem Befehl.

7. Mein Anfang ist Yār, mein Ende ist Yār

8. Unter dem Befehl des lieblichen Xāvändigār.

Die siebte Nacht bzw. der achte Tag im Dāvātloq ist das Yārıstān-Fest oder Königsfest: ein Yārıstān-Jahr ist zu Ende und das neue Jahr beginnt. In dieser Nacht wird manchmal bis zum Sonnenaufgang gefeiert. Es werden mehrere Nyāz verteilt. Es wird viel

\footnotetext{
${ }^{80}$ Dieses Gebet findet sich in der Kälāmāt-1 torkī nicht. Ich kann das Gebet auswendig.
} 
gesungen und Tanbur gespielt. Die Kälāmāt stellen die Freude der Yārıstān an den Dāvātloq-Nächten wie folgt dar:

4. Die Freunde der Wahrheit vereinigen sich. Es ist eine gesegnete Nacht, es ist eine gesegnete Nacht.

5. Das Licht, die Sonne und der Mond, die Erde und der Himmel sind alle sein (Sulțān Säḥāks) Hof.

6. Seines Hofes Tor ist offen für alle, die sich nach ihm sehnen. Es ist eine gesegnete Nacht! Es ist eine gesegnete Nacht!

7. Mein Herr (Sulțān Säḥāk) ist einzigartig, er ist überall anwesend.

8. In dieser Nacht findet das größte Fest von Yārıstān statt. Es ist eine gesegnete Nacht, es ist eine gesegnete Nacht.

9. Alle Menschen schlafen, nur die Leute, die der Wahrheit würdig sind, sind wach.

10. Die Engel stehen zu Diensten, es ist eine gesegnete Nacht, es ist eine gesegnete Nacht.

(Kälām Nr. 6)

$\mathrm{Da}$ das Opfern ein Bestandteil der wichtigen Ritualen ist, zählt dieses zu den wichtigsten Zeremonien. Als ein regelmäßiges Ritual findet das Opfern (Qurbānloq) in der Mitte des Herbstes statt. Der Ablauf der Opfer-Zeremonie in allen Ritualen ist dem Ablauf des Opfer-Rituals gleich. Alle Opferzeremonien haben denselben Inhalt, die man im Wort „bärähbändī“ („Lamm besorgen“) ausdrückt. Es können nicht nur Vieh (s.o.) oder Hühner, sondern auch Granatäpfel und Butter geopfert werden.

Im Regelfall findet das Opfer-Ritual bzw. die Opfer-Zeremonie im Jäm statt. Der Xādım, der für die Organisation und den Ablauf dieses Rituals verantwortlich ist, sammelt von allen Jäm-Mitgliedern Geld für die Opfertiere. Jeder zahlt, so viel er kann. Mit diesem Geld besorgt der Xādım am liebsten einen Ochsen. Am Vorabend vor dem Fest wird das Tier geschlachtet. Dafür benutzt man ein spezielles Messer, über welches zuvor ein bestimmtes Gebet gesprochen wurde. Das Messer wird mit einem anderen Messer von Binyāmīn, das Keyborr hieß, assoziiert. Mit diesem Messer opferte Bınyāmīn einen Stier Namens Kälzärdä, der eigentlich ein Teil von Yādıgār war.

Aus dem Blut des geopferten Tieres wird sofort eine Speise zubereitet. Der Xādım mit dem Pīr und den zwei anderen Jäm-Dienern essen diese Speise auf. Das Fleisch wird 
nachher geteilt. Das Innere gehört auch auf den Speiseplan. Nur das Fell und der Darm werden verkauft und das dafür erhaltene Geld wird für das Einkaufen von Süßigkeiten verwendet. Der Magen und die Knochen des Tieres werden am nächsten Tag begraben. Das Fleisch wird in einem Jäm-Topf gekocht und in einerm Jäm-Behälter aus Keramik gesalzen. Das Fleisch wird portioniert, ins Brot hinein getan und eingepackt, um später unter den Jäm-Teilnehmern verteilt zu werden. Die Brühe wird auch verteilt.

\section{Rituale aus einem besonderen Anlass}

Unter diese Kategorie fallen die folgenden Rituale, die gegebenenfalls stattfinden: die Namensgebung, die Initiation, die Hochzeit und die Beerdigung.

\section{a) die Namensgebung}

Dieses Ritual findet in den ersten sechs Tagen des Lebens eines neugeborenen Kindes statt. Der Name des Kindes wird im Voraus von den Eltern gewählt. Am Tag der Zeremonie des Namensgebens kommen die erfahrenen Frauen aus der Verwandtschaft oder auch aus der Nachbarschaft zur Mutter des Neugeborenen und helfen ihr, das Kind für die Zeremonie vorzubereiten. Das Kind wird zunächst gewaschen, danach wird ihm neue Kleidung angezogen. Das Kind wird in Begleitung seiner Eltern und anderer Verwandter zum Jäm gebracht, wo es schon vom Pīr erwartet wird. Der Pīr nimmt das Kind auf seinen Arm und flüstert in sein rechtes Ohr ein Gebet. Dieses wird am Ende mit „Amen“ von allen Anwesenden bestätigt. In diesem Gebet wird der Wunsch ausgesprochen, dass das Kind gesund, glücklich und ehrlich sein wird, dass es ein „warmer“ und nicht zweifelnder Yārıstān-Angehöriger wird.

Alle Jäm $^{81}$ nehmen das Kind nacheinander auf den Arm und flüstern sieben Mal seinen Namen in sein rechtes Ohr.

Es wird Nyāz ins Jäm mitgebracht und unter den Jäm-Teilnemern zeremoniell verteilt: dabei wird ein entsprechendes Gebet gelesen.

\section{b) die Initiation (Särsıpārī )}

Dieses Ritual findet in den ersten vierzehn Tagen des Lebens eines Kindes statt und ist vorgeschrieben.

Im Regelfall wird es als die Verlängerung der Zeremonie des Namensgebens durchgeführt. Die Eltern müssen dafür Reis und ein Opfertier zubereiten. Es werden

\footnotetext{
${ }^{81}$ So werden auch die Ĵ̈m-Teilnehmer bezeichnet.
} 
auch Süßigkeiten, Muskatnüsse, ein neues weißes Leinenhandtuch und eine Geldmünze ins Ĵäm mitgenommen. So beschreibt dieses die Kälāmāt-1 torkī:

7. Bringt die Geldmünze und das Handtuch mit.

8. Macht Kırdār, weil der Jouz (Muskatnuss) von Bınyāmīn bei mir ist.

(Kälām Nr. 92)

Die Zeremonie wird von einem verehrten Gemeindemitglied, das nicht unbedingt ein Verwandter oder ein naher Freund der Familie sein muss, durchgeführt. Dieser Mann ist auch bereit, die Verantwortung für das Kind zu übernehmen, wenn seine Eltern z. B. sterben. Die Rolle eines Führers, die er während der Zeremonie spielt, symbolisiert die Rolle Dāvūds als Yārıstān-Führer.

Der Pīr bindet das weiße Handtuch um den Hals des Zeremonieführers. Dieses Handtuch symbolisiert eine Verbindung zwischen dem Kind, dem Zeremonieführer und dem Pīr. Der Zeremonieführer berührt einen Hemdzipfel eines der männlichen Verwandten des Pīrs. Ein Jäm-Diener schneidet eine Muskatnuss durch und flüstert dabei ein Gebet: „Im Namen des Kindes, im Namen des Vaters, im Namen der Xānıdān, nach dem Befehl des Sulțān der Welt, die Erde und der Himmel sind Augenzeugen, ebenso vor den Augen des Jäms und der Jäm-Teilnehmer! Der ewige Pīr ist Binyāmīn. Der ewige Führer ist Dāvūd. Im Namen des (hier wird der Name der Xānıdān erwähnt) Pīrs“. Die Muskatnuss wird unter den Anwesenden verteilt und ein Stück davon wird für das Kind aufgehoben. Diese Zeremonie wird mit einem Gebet und einem gemeinsamen „Amen“ beendet.

Dann ist es Zeit für das gemeinsame Essen.

Mit der Geldmünze, die die Eltern mitnahmen, werden nachher Süßigkeiten für die nächste Jäm-Versammlung gekauft.

\section{c) die Hochzeit}

Diese Zeremonie findet im Jäm statt. Die Braut und der Bräutigam schreiben ein gūrānīsches Kälām von Pīr Mūsī - jeder auf einen Zettel - und unterschreiben es. Darin geht es um die Grundwerte und die Voraussetzungen eines glücklichen Ehelebens in der Yārıstān-Gemeinde. Der Pīr des Jäms deklamiert und interpretiert dieses Kälām. Danach nimmt er beiden den Eid der gegenseitigen Treue ab. Die Braut und der Bräutigam tauschen ihre Zettel aus. Die Ehe ist geschlossen. Einer von beiden Eheleuten liest das Kälām noch einmal laut für alle Anwesenden vor. 
Dann ist es Zeit für das gemeinsame Essen. Dafür wird im Voraus ein Opfertier geschlachtet und zubereitet. Die Essenszeremonie wird wie bei allen anderen Ritualen durchgeführt.

Die Türkisch sprechenden Yārıstān im Iran leben unter den Schiiten und dürfen ihr Hochzeit-Ritual nicht öffentlich vollziehen: die Eheschließung nach den YārıstānRegeln ist keine staatlich anerkannte Zeremonie und schon überhaupt keine erlaubte Aktion. Die Braut würde gesteinigt und der Bräutigam würde hingerichtet. Offiziell heiraten die Paare nach islamischem Ritus.

\section{d) die Beerdigung}

Wenn ein Yār stirbt, kommen viele Yārān (manchmal 600 bis 700 Menschen) zu seiner Beerdigung, die am Tag des Sterbens stattfinden muss.

Der Körper des Verstorbenen wird mit Wasser gewaschen. Danach wird ein gūrānīsches Gebet von Binyāmīn gemeinsam leise gelesen:

Bînyâmîn maramo:

5. î âwmân maj way sar sifâtî

6. way qâbi rohi bâqîsh hayâtî

7. ja hazâr u yak dûn bûnîsh najâtî

8. âsûdagîsh bo jay rây mamâtî

9. rây dîdadârîsh bo na qinyâtî
Bınyāmīn sagt:

5. Dieses Wasser wird auf deinen Körper gegossen, weil es gute Eigenschaften besitzt.

6. Es wird auf diesen Körper gegossen, dessen Seele ewig lebt.

7. In Tausend und einem Körper sei gerettet

8. Und bleib ruhig auf dem Wege der Seelenwanderung.

9. Sei zufrieden, während du auf die Wahrheit wartest.

(Gänj̄̄nneh-e Yārī)

Das Wasser wird nachher neun Mal über den ganzen Körper des Verstorbenen gegossen: dreimal von Kopf bis Fuß, dreimal auf die rechte Seite, dreimal auf die linke Seite. Es wird dem Verstorbenen ein Leichengewand angezogen. Die Leiche wird in einem Holzsarg vom Haus zum Friedhof gebracht. Der Sarg wird neben das Grab gestellt. Die Yārıstān stellen sich um den Sarg herum. Sie sprechen ein gemeinsames Gebet. Es werden unter allen Anwesenden Süßigkeiten verteilt. Dann wird ein 
gūrānīsches Kälām von Sulțān Säḥāk gelesen. Die Leiche wird aus dem Sarg herausgenommen und ins Grab gelegt. Dann wird das Grab mit Erde gefüllt. Als letztes wird ein Stein mit den Geburts- und Sterbedaten auf das geschlossene Grab gelegt. Einer der Verwandten entzündet auf dem Grab ein Feuer. Wenn das Feuer erloschen ist, wird ein Abschlussgebet gelesen. Eine Laterne leuchtet auf dem Grab drei Nächte lang. Da die Seelenwanderung die Grundlage des Yārıstān-Glaubens bildet, betrachten die Gläubigen das Sterben als eine Umgestaltung:

3. Welten sind vergangen. Wir werden auch vergehen.

4. Nennt ihr uns nicht „Gestorbene“! Es ist eine Umgestaltung für uns.

(Kälām Nr. 36)

Die Yārıstān dürfen wegen eines Sterbefalles nicht traurig sein und schon überhaupt nicht weinen. Sie dürfen keine schwarze Kleidung anziehen oder auf irgendeine andere Weise ihre Trauer ausdrücken. Ein Yārıstān-Gläubiger liest im Andenken an den Verstorbenen ein Seelengebet vor, um die Hoffnung nicht zu verlieren:

Eyv-Ällāh rūḥ o rävān

hımmät eyläyun gıčänlärun rūḥı

šād olsun

āqālärı ḥuẓūrinda särfrāz olsun

Bınyāmīnun šärțindan gärı qalmasun

Dāvūd sädda ögönäh čäkılmasun

Pīr-Mūsīnun qälämindan dušmasun

Pāk-1 Rämzbārun Xıdmätina bag̉ušlansun

Kırdārı ögönda čırāg olsun

donlärda yārliq donilän gälsun

älı Pīr o Dälīl ätägindän uzulmasun

ävväl āxır Yār
Gott mag die Seelen und das Leben.

Bemüht ihr euch, für die Seelen der verreisten (verstorbenen) Menschen zu beten, damit ihre Seelen fröhlich und stolz vor Gott werden; damit sie den Pakt von Bınyāmīn bewahren und Dāvūd es ihnen leichter macht, ihren Weg zu gehen; damit Pīr Mūsī sie in seine Liste einträgt und die heilige Rämzbār das X1dmät von ihnen annimmt; damit ihre Tat wie eine Laterne weiter leuchtet und die Seelenwanderung unter den Yārān weiter geht; damit ihre Hand von der Hand des Pīrs und der des Führers nicht getrennt wird. Mein Anfang ist Yār, mein Ende ist Yār. 


\section{Gebete}

Jeder Schritt sämtlicher Rituale wird von einem oder mehreren Gebeten begleitet. Diese Gebete gehören zum Jäm und dürfen nur vom Pīr und den Jäm-Dienern vorgetragen werden. Uneingeweihte kennen diese Gebete nicht.

Es gibt aber auch manche Gebete, die gemeinsam von den Jäm-Teilnehmern gesprochen werden, wie z. B. das folgende Gebet aus der Äsrār-e Yārī, das nach dem Ankommen von allen Jäm-Teilnehmern im Jäm laut deklamiert wird:

1. šukur älhämd o-l11āh biz Yāra irdux.

2. sizuntäk pāknäżär dīdārä irdux.

3. irišdux Yārun ähl-1 beytına.

4. kärämkānı äzīz-Xāvändıgāra irdux.

5. dukānunda jāan o bašlar satolur.

6. `äjäb äsās butun bāzāra irdux.

7. Bınyāmīnilän girdux bir duna

8. gungullär yapuči mi`māra irdux.

9. murīd-1 Xānıdān oldun Qäländär.

10. `äjäb ähl-1 yäqīn särdāra irdux.
1. Gott sei Dank, dass wir zu Yārān gekommen sind.

2. Gott sei Dank, dass wir euch tugendhaft aussehend begegnet sind.

3. Gott sei Dank, dass wir die YārānGemeinde besucht haben.

4. Gott sei Dank, dass wir den großherzigen Xāvändigār besucht haben.

5. Gott sei Dank, dass wir unser Leben und unsere Köpfe ihm widmen.

6. Gott sei Dank, dass wir so eine absolut wunderbare Handlung gesehen haben.

7. Gott sei Dank, dass wir hier mit Bınyāmīn in einem Körper sind.

8. Gott sei Dank, dass wir die Wahrheit, die von allen gewünscht wird, erreicht haben.

9. Gott sei Dank, dass du, Qäländär (der Name des Dichters), ein Anhänger der Wahrheit bist.

10. Gott sei Dank, dass wir einen 
wunderbaren Wahrheitsführer

getroffen haben.

Das nächste Gebet wird auch gemeinsam gesprochen, wenn eine zeremonielle Mahlzeit im Jäm beendet wird:

1. Oh, Gott! Was ich esse, ist eine Wohltat von dir.

2. Die Schöpfung einer würdigen Nation (Yārıstān) gehört dir.

3. Ich bin ein Sünder und du bist der Barmherzige.

4. Du bist gewiss die Quelle der Großmut. Die Großmütigkeit ist von dir.

5. Die Könige können deinen Zorn nicht ertragen.

6. Die Erde und der Himmel erschrecken sich.

Diese erschreckende Macht gehört dir.

7. Wenn du den hohen Gebirgen sich zu beugen befiehlst, beugen sie sich.

8. Sie beugen sich, sie fallen aber nicht um.

Diese Widerstandskraft ist von dir.

9. Das Gesicht der Erde schmücktest du mit Blumen wie mit Perlen.

10. Eine so wunderbare Tat kommt nur von deiner Weisheit.

11. Was von deinem Geheimnis zu sehen ist, sind die achtzehntausend Universen.

12. Man betet dich in 72 Sprachen an.

13. Wach auf, du Quščioġlı! Wie kannst du schlafen?

14. Obwohl du ein Taubstummer ${ }^{82}$ warst, hast du jetzt das Glück, zu sprechen.

(Kälām Nr. 39)

Im Anschluss an dieses Gebet wird Wasser getrunken und gleichzeitig ein anderes Kälām vom Pīr vorgelesen. Dieses Kälām gehört zu jeder Zusammenkunft im Jäm:

1. Der betrunkene Verliebte lässt den Schenk nicht aus dem Auge (ein Yār denkt immer an Gott).

82 Diese Passage spielt auf die Heilung Quščıg glıs bei Šāh Ibrāhīm in Bäğdād ein. Mehr dazu siehe im Kapitel II.1.1. 
2. Er trinkt ohne zu zweifeln von der Hand des Schenks aus seinem kostbaren Weinpokal immer weiter.

3. Ich sah in seinem Gesicht ohne zu zweifeln das heilige Haus der Kaaba.

4. Ich sah in seinen Augenbrauen für mich den Mihrab (den Ort des Gottesdienstes).

5. Ich freute mich zuerst wegen seiner schwarzen Haare und dann ging ich in den Kovsär-Brunnen ${ }^{83}$ hinein.

6. Ich trank vom ewigen Wein Gottes (ich erhielt die Kälām-Hefte), dann bekam ich das ewige Leben.

7. Wasser, Feuer, Erde und Wind sind bedeutend in diesem edlen Haus, wo Ordnung das Hauptprinzip ist.

8. Ich suchte nach der Wahrheit, ich fand die Wahrheit. Siehe, was für Kenntnisse der Verliebte besitzt.

9. Du bist der Geliebte (Gott) von Qulvälī, mach noch einen Schritt weiter und komm zu uns.

10. Wenn du kommst, wird mein Wunsch glänzend (erfüllt).

(Kälām Nr. 310)

Die Jäm-Teilnehemer können dieses Gebet auswendig, dürfen es aber nicht mitflüstern. In diesem Kälām werden die Zuneigung und sogar die Leidenschaft des Gläubigen für Gott dargestellt. Gott selbst erscheint den Gläubigen wie ein gleichberechtigter Yār, der direkt angesprochen werden darf.

Außer den Jäm-Gebeten gibt es auch tägliche Gebete, die das Alltagsleben eines Yārıstān-Gläubigen gestalten. Es wird morgens und abends jeweils einmal gebetet. Beim Beten muss man sich jeweils gegen Sonnenaufgang und Sonnenuntergang wenden. Vor dem Gebet müssen die Hände und das Gesicht gewaschen werden. Man kniet sich auf einen nur für sich selbst bestimmten Platz im Hause, sitzt gerade, hält seinen Kopf hoch und flüstert das Gebet.

Der neue Monat beginnt für die Yārıstān mit dem Neumond. An diesem Abend ist es üblich, ins Jäm zu gehen. Als erste Rede wird das Monatsgebet vom Pīr vorgetragen und von den Anwesenden gemeinsam laut wiederholt:

1. Ihr Yārān, in dieser Nacht traf ich den König.

2. Ich sah in dieser Nacht im Universum den Mond.

\footnotetext{
${ }^{83}$ Der KovSär-Brunnen ist ein Brunnen im Paradies.
} 
3. Ich sah sein hübsches Gesicht und wurde sehr glücklich.

4. Ich betete in dieser Nacht am Hof (Gottes) an.

5. Ich streckte meine Hand aus, um mich an seinem Hemdzipfel zu halten.

6. Er sagte zu mir: „Lies in dieser Nacht aus dem Koran die Ṭāhā-Verse vor“.

7. Ich sagte: „Du `Älī, erfülle meinen Wunsch“.

8. Er sagte: „Du bekommst die Erfüllung in dieser Nacht““.

9. Als Quščıg

10. Bekam er unerwartet einen Schatz.

(Kälām Nr. 234)

Die Yārıstān nennen ihr Jäm „Heilmittel“, nicht nur deswegen, weil sie seelische Sehnsucht nach ihm haben, sondern auch weil sie glauben, dass ein Kranker im Ĵäm wieder gesund wird. Es gibt ein Gebet, das vom Pīr oder einem anderen Kälām-Sänger im Jäm für die Besserung der Kranken gesungen wird:

1. Yār ist meine Hoffnung und mein Erbarmer von Anfang an.

2. Ich habe die Hoffnung auf den Königsthron von Anfang an.

3. Das Fundament der Sieben Wesen in diesem Weltall,

4. Vom Westen bis zum Osten, ist ein Blumengarten von Anfang an.

5. Die Leute, die von Anfang an „Ja“ zur Wahrheit sagten,

6. Sind nicht skeptisch und sind akzeptabel von Anfang an.

7. Eine Perle kam aus dem Universum.

8. So viele Kenner wollten sie kaufen von Anfang an.

9. Die Leute, die aus dem Weinkelch Ibrāhīms tranken,

10. Sind nicht nüchtern, sie sind betrunken von Anfang an.

11. Alle Leidenden werden zum Jäm geschickt.

12. Jäm ist das Heilmittel gegen alle Schmerzen von Anfang an.

13. Yārān, wisst Bescheid, dass Quščığlı aus der Perlenquelle

14. Seinen Anteil bekam und voll Weisheit ist von Anfang an.

(Kälām Nr. 175)

Kranke Kinder, Männer und Frauen werden von ihren Verwandten ins Jäm gebracht. Das Gebet wird in Begleitung eines Tanburs für sie gesungen. Die geheilten Yārān glauben fest, dass sie im Jäm geheilt worden sind. 


\section{Vorschriften}

Die Yārıstān haben zahlreiche Vorschriften, die ihr religiöses und soziales Leben bestimmen. Sie sind aus den Weltanschauungs- und Moralprinzipien, sowie auch aus den Prinzipien des sozialen Gewissens der Yārıstān abgeleitet.

Verboten ist zunächst das Zweifeln an der Grundlage der Yārıstān-Religion: an der Wahrheit und der Seelenwanderung. Das nächste Verbot ist das Veröffentlichen von Yārıstān-Geheimnissen.

Wenn die Yārıstān-Gläubigen ins Jäm gehen, verbergen sie ihre Haare unter Kopftüchern oder Mützen. Sie dürfen im Jäm nur nach den Vorschriften gekleidet erscheinen. Sie wickeln um ihren Rücken einen Schal oder einen Gurt:

11. kämärin qurša var ĵäm ičinda.

12. Xō̂ämm dīdārını gostärur ona.

21. Ṭāyfa olana vırıldı Xıdmät

22. kämärın quršadı Pīrdän nıšāna
11. Wickel um deinen Rücken einen Schal und trete ins Jäm ein.

12. Mein Herr zeigt dir dann sein Gesicht. (aus dem Kälām Nr. 221)

21. Jemand, der Yār geworden ist, hat eine Verpflichtung übernommen:

22. Seinen Rücken zu umwickeln, weil es ein Zeichen des Pīrs ist.

(aus dem Kälām Nr. 230)

Die Männer dürfen ihre Oberlippenbärte nicht rasieren:

7. Die schnurrbärtigen Diener (die echten Yārān) können ihren Herren nicht verlassen.

(Kälām Nr. 42)

9. Du Qänbär ${ }^{84}$, weiß Bescheid, dass wer einen perfekten Schnurrbart hat,

10. Im Dīvān Gottes (Gerichtshof Gottes) geliebt wird.

(Kälām Nr. 60)

Die Sauberkeit ist ein Gebot für die Yārıstān, besonders wenn sie sich auf den Weg ins Jäm machen. Die Hausfrauen, die vorhaben, Speisen für ein Fest im Jäm zuzubereiten, müssen zuhause ein Säuberungsritual durchführen.

\footnotetext{
${ }^{84}$ Qänbär ist der Name des Dichters dieses Kälāms.
} 

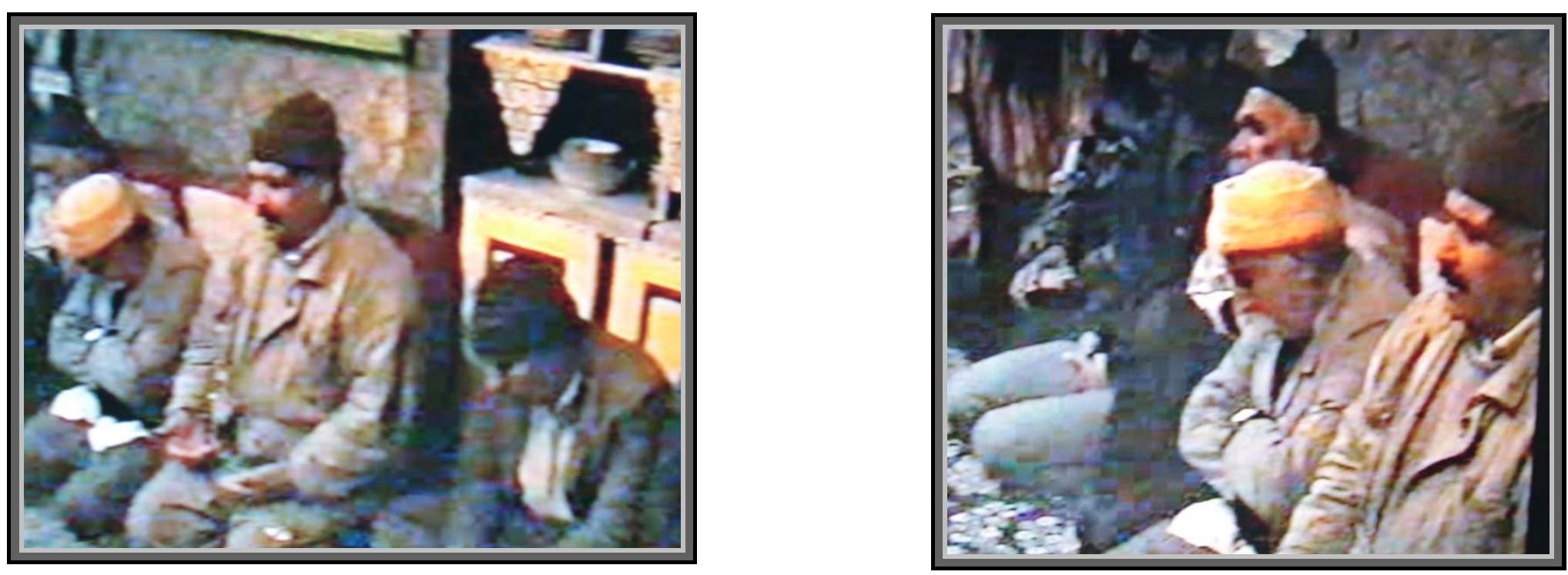

Die Yārıstān-Gläubigen dürfen im Jäm nur nach den Vorschriften gekleidet erscheinen: sie verbergen ihre Haare unter Kopftüchern oder Mützen, wickeln um ihren Rücken einen Schal oder einen Gurt. Sie sitzen im Jäm auf ihren Fersen mit auf der Brust gekreuzten Armen und nach links gesenktem Kopf (aus einer privaten Videoaufnahme). 
Dieses Ritual heißt „Ġosl-e Niyät“(,Waschung für die Niyät"). Sie waschen ihren Körper und flüstern dabei ein gūrānīsches Gebet. Darin geht es um die Weltentstehung und die Yārıstān-Geschichte bis zur Sulțān Säḥāk-Ära. Das Gebet wird mit den üblichen Worten „Mein Anfang und mein Ende ist Yār" beendet. Danach sagen sie über dem Wasser in ihrer Hand: „Du bist ein Teil von der Ṭäšār-Quelle, du reinigst unseren Körper und unsere Kleidung. Ich wasche mit dir mein Leben und meine Seele“. Sie trinken von diesem Wasser und gießen den Rest auf ihren Körper.

Im Jäm sitzen alle auf ihren Fersen auf dem Boden. Während einer Zeremonie dürfen sie nicht miteinander sprechen oder lachen, ihre Köpfe müssen nach links geneigt werden. Diese Kopfposition symbolisiert, so die Yārān, die Hinrichtung eines berühmten Yārs namens Ḥällāĵj ${ }^{85}$ durch Muslime. Während des Essens im Jäm dürfen sie weder ihre eigene noch die Konzentration anderer stören. Die Hände müssen vor und nach dem Essen unbedingt sorgfältig gewaschen werden. Das Wasser wird nachher draußen auf die freie und saubere Erde ausgegossen.

Die Eheleute dürfen während des Dāvātloqs keinen Geschlechtsverkehr haben. Ähnliche Verbote des Geschlechtsverkehrs bei den Yeziden beschreibt Philip Kreyenbroek in "Yezidism - its background, observances and textual tradition": "Sexual intercourse, it seems, is forbidden on the eve of Wednesdays and Fridays, the two weekly holy days, and at Sheykh Adi during the Festival of the Assembly" (vgl. Kreyenbroek 1995, S. 150).

Man darf nie weder Alkohol noch Tabak oder Opium konsumieren und muss sich an die Vorschriften des Fastens halten. Wenn ein Yār gegen die Vorschriften der Yārıstān verstößt, entsteht auf seiner Zunge, so glauben die Yārıstān, eine unheilbare Wunde.

Es gibt keine Vorschriften in der gesamten Yārıstān-Lehre, die den Zutritt der Frauen ins Jäm verbieten. Es gibt einen Raum im Jäm-Xāna, worin sich die Frauen aufhalten dürfen. Pāk-e Rämzbār - eine der Sieben Wesen - ist eine Frau. Sie ist die heilige Mutter von Sulțān Säḥāk und wird von den Yārān angebetet. Es ist aber nur den Männern gestattet, ins Jäm zu gehen. Das begründen die Gläubigen selbst so, dass die Yārıstān oft von Muslimen beschuldigt wurden, ihre Frauen in die Öffentlichkeit mitzubringen.

\footnotetext{
${ }^{85}$ Hällâj $(† 307$ (920)) ist eine berühmte Figur in der iranischen Geschichte. Manche halten ihn für einen Zauberer. Manche rechnen ihn als den größten Mystiker in islamischer Zeit. Andere nennen ihn „Sündiger“ und „Ketzer“(vgl. Dehkhoda 1968, Band 20, S. 769).
} 


\section{Die Yārıstān und die Musik}

Die Musik der Yārıstān ist ein Zweig der iranischen Musik. Sie enthält Elemente der Volks- und Regionalmusik Irans. Sie sei, so B. Būstān und M. Därwiš̃ in ihrem Buch „Morūrī bär mūsīqīee sonnätī wa mäḥällīee Iran“, von ihrer Heimat Havrāmān über den Loristan bis nach Bälučistān verbreitet (vgl. Būstān/Därwišì 1991, S. 125ff.).

Obwohl ihre havrāmīsche Herkunft unbestritten ist, wird sie aber von den Türkisch sprechenden Yārıstān in den Provinzen Aserbaidschan, Hamadān, Zänjān und Teheran auch tradiert. Außerdem sind die Musikologen auf dem Gebiet der Yārıstān-Musik auch der Meinung, dass sie zahlreiche Merkmale wie z. B. Rhythmus, Takt, Modulation, die für die altiranische Musik kennzeichnend sind, aufweist (vgl. Būstān/Därwišīì 1991, S. 109; During 1991, S. 12).

Es gibt zwei Hauptarten in der Yārıstān-Musik: Mūsīqī-e maqamī, oder freie Musik, und Mūsīqīe kälāmī, oder heilige Musik. Während die Mūsīqīe maqamī für die Musikethnologen zugänglich ist (vgl. Hamzeh'ee 2006, S. 183f.), bleibt die Mūsīqīee kälāmī für Musikwissenschaftler verschlossen.

Die Yārıstān-Musik wird meistens mit einem einzigen Instrument gemacht - mit dem Tanbur. Das ist eine langhalsige Laute, die 12 bis 15 Voll- und Halbtöne hat und nur eine Oktave umfasst. Ihre Gestalt erfuhr seit der Sāsāniden-Zeit (seit dem 2. Jhr. n. Ch.) keine Veränderung (vgl. Dehkhoda 1968, Band 34., S. 322; During 1991, S. 11). Dieses Instrument ist unter den Yārıstān sehr beliebt und gilt als heilig. Vor und nach dem Spielen wird es vom Musiker geküsst (vgl. Būstān/Därwišì 1991, S. 114).

Die weiteren Instrumente sind regionale Blasinstrumente wie Surna, Duzäleh, Šemšāl, Närmehnei und Schlagzeug wie Dohol, Däf, Tās.

Zum Verständnis der Musik der Yārıstān ist es nötig, die Struktur der iranischen Musiktradution kurz darzustellen.

Die Grundlage der iranischen Musik bilden 360 Āhäng. Sie sind die Original-melodien, die von 3 Sek. bis 1,5 Min. dauern und durchschnittlich aus 7 Takten bestehen. Das nächste musikalische Gebilde sind 228 Gūšeh. Sie sind die kleinsten Kompositionen, die durchschnittlich aus 9 Āhäng bestehen. Die größten musikalischen Einheiten sind 5 Näg̈meh, die jeweils aus 16 bis 27 Gūšeh bestehen, und die 7 Dästgāh, die jeweils aus 36 bis 70 Gūšeh bestehen.

Die Yārıstān-Musik wird aber mit anderen Begriffen beschrieben: Mäqām für Gūšeh und Ṭärz für Dästgāh (vgl. Ma`aroufi1995, S. 37-53). Die Musik der Yārıstān kennt drei Ṭärz: Mä̂̂nunī, Räzmī und Kälām (vgl. Būstān/Därwišĩ 1991, S. 110). 


\section{- Mūsīqīe mäqāmī}

Sie ist die weltliche Musik, die meistens von den Yārıstān-Musikern komponiert und frei - außerhalb des Jäms - gespielt und gesungen wird.

Mūsīqī-e mäqāmī besteht aus den zwei musikalischen Richtungen:

- altiranischer Gesang mit instrumentaler Begleitung vom Tanbur bzw. von den zwei Tanburen in traditionellen Kammermusikformen „Hūra“, „Mūr““, „Lūre“, „Siāčämānä“"86 und

- pastorale bzw. populäre Musik für Singstimme und Tanbur.

Die freie Musik wird bei Hochzeiten, Geburtstagen, während des Feierns weltlicher Feste wie z. B. des Novrūz-Festes oder des Sīzdehbehdär-Festes (am 13. Tag nach dem Novrūz) gespielt. Für die Musikstücke in der Musiqī-e mäqāmī gibt es Improvisationsmöglichkeiten, so wie es in der iranischen Nationalmusik üblich ist.

Es gibt, so Būstān und Därwiš̄i (1991), zwei Ṭärz für die Mūsīqī-e mäqāmī: Mäĵnun̄̄ und Räzmī (oder Rustämī). In der Mäjnunī-Tonart werden überwiegend lyrische Liebeslieder, Lieder über die Jahreszeiten oder über die Blumen gespielt und gesungen. In der Räzmī-Tonart werden heldenhafte Stücke gespielt und gesungen. In den beiden Tonarten wird auch Tanzmusik mit Gesang komponiert die „Čäpī“, „Lärzāneh“, „Fätāḥ

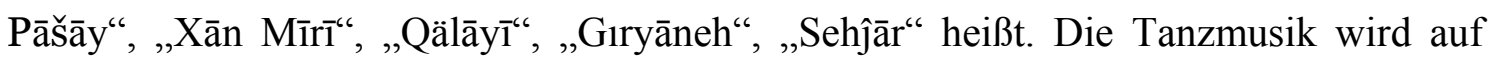
regionalen Blasinstrumenten und auf großen Trommeln gespielt (vgl. Būstān/Därwiš̄ 1991, S. 112f.).

Einer der besten Yārıstān-Musiker des vergangenen Jahrzehntes war Säyyed Xälīl 'Alīnežād ${ }^{87}$ (1957 - 2001). Er ist vor allem als Tanburspieler weltweit bekannt. Seine Konzerte fanden im Iran, in vielen europäischen und asiatischen Ländern statt. Während eines Konzerts in Schweden wurde er am 18. November 2001 von unbekannten Tätern durch mehrere Messerstiche ermordet.

\footnotetext{
${ }^{86}$ Mehr dazu siehe in Hamzeh'ee 2006, S. 182-188.

${ }^{87}$ Eine Kopie einer privaten Videoaufnahme, die von den Yārān gemacht wurde und von Säyyed Xälīl 'Alīnežād gespielte Mūsīqī-e mäqāmī-Stücke enthält, befindet sich in meinem Besitz.
} 


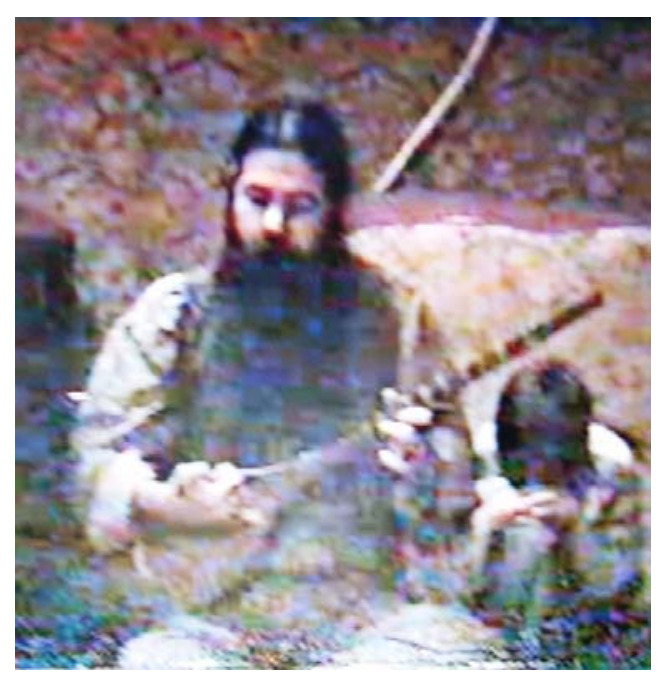

Aus einer privaten Videoaufnahme:

Säyyed Xälīl ‘Alīnežād (1957 - 2001). 


\section{- Mūsīqī-e kälāmī}

Diese Musik ist die heilige Musik der Yārıstān und darf nur für Eingeweihte und nur im JämXāna gespielt werden. Die Instrumente werden ausschließlich für den Zweck, die Mūsīqī-e kälāmī zu spielen, benutzt.

Diese Musik ist ein wichtiges Element der Rituale. Der Rhythmus, die Tonhöhe, die Melodie selbst führen den Menschen in einen transzendenten Zustand, und dadurch wird die Vereinigung der Gläubigen mit der absoluten Wahrheit erzielt. Die Mūsīqī-e kälāmī wird obligatorisch während der sieben Dāvātloq-Nächte gespielt. Sie wird manchmal aber auch, je nach der Entscheidung des Pīrs, während der regelmäßigen Donnerstagsversammlungen gespielt. Meistens kommt es dazu, wenn gerade ein guter Kälām-Sänger zu Besuch ist.

Es gibt nur ein Ṭärz für die Mūsīqī-e Kälāmī - Ṭärz-e Kälām. Ṭärz-e Kälām besteht aus 72 Mäqām. Es werden Musikstücke für Sologesang mit Tanbur-Begleitung oder für einen Chor mit Begleitung von rhythmischem Klatschen und Tanbur komponiert. Diese Kompositionen sind festgelegt, und es darf dabei nicht improvisiert werden.

Ein Mäqām stellt eine Reihe von bestimmten Melodien dar. Diese Melodien sowie das ganze Ṭärz-e Kälām sind der musikalischen Öffentlichkeit unbekannt. In meinem Besitz ${ }^{88}$ befinden sich aber einige Tonbänder mit Aufnahmen der die Mūsīqīee kälāmī begleitenden Rituale: Aufnahmen von Kälām-Gesängen mit rhythmischen Klatschen und Tanbur-Begleitung.

Die erste Aufnahme enthält einen Gesang von Kälām Nr. 183. Dieses Kälām wird während der Dāvātloq-Nächte gesungen. Das Tanbur-Solo beginnt in der Mahur-Tonart in einer ĀvāzīForm ohne Metrum, die vom Čäp-i däst-Rhythmus 4/4, Tempo 190, ohne Gesänge abgelöst wird und am Ende wieder zur Āvāzī ohne Metrum zurückkehrt. Dann spricht der Pīr zum Nyāz ein Gebet, und das Kälām-Singen (Kälām Nr. 183) in Näg̉meh-e Daštī beginnt:

1. Ich rufe ständig meinen Gott.

2. Wenn ich einmal seufze, mache ich die Welt zum Feuer (verbrenne die Welt).

3. Du sagtest, dass du das Wahre vom Unwahren trennst

4. Und mehrere tausend Nichtse zum Dasein bringt.

5. Ich widme kühn meinen Kopf dem König der Liebe.

6. Wenn ich Leidenschaft bekäme, würde ich meine Ehre zu Schanden machen.

\footnotetext{
${ }^{88}$ Weil ich seit über 20 Jahren weit entfernt von der Yārıstān-Gemeinde lebe, hat der Särjäm Säyyed Färox Mūsävī (Xānıdān-e Säyyed Müștäfā in Hamadān) meiner älteren Schwester Hešmät Geranpayeh erlaubt, manche Tonaufnahmen für mich zu machen. Mit seiner Erlaubnis waren die Jäm-Teilnehmer einverstanden.
} 
7. Wie eine Nachtigall wünsche ich mir dein blumenartiges Gesicht

8. Und bringe die Nachtigall im Blumengarten zum Jammern.

9. Die blutigen Tränen fließen aus meinen Augen.

10. Manchmal werde ich zum Mairegen, manchmal schneie ich.

11. Das alte Kälām war bei dem Gūrān-Volk,

12. Jetzt schreie ich für Turkistan.

13. Ich bin Šähsävāroġlı (der Dichter) und mache mein Geschäft:

14. Mit dem Yār verkaufe ich und gewinne.

(Kälām Nr. 183)

Dieser Kälām-Gesang ist strukturell gesehen ein Vorwort, eine Ouvertüre zum Čäp-i däst dem gemeinsamen rhythmischen Klatschen und dem Chorsingen. Die zwei Čäp-i däst-Zeilen werden als Refrain ganze 20 Minuten mit Tempo 190 ohne Pausen wiederholt:

1. Sultāan-i sär Jäm Xāvändıgāri 1. Xāvändıgār, der König, das Haupt vom Jäm,

2. saxla bälādän sän jümläh Yāri $\quad$ 2. Beschütze alle Yārān vor Unglück.

Die zweite Aufnahme enthält einen Gesang vom Kälām Nr. 208. Dieses Kälām wird ebenso in den Dāvātloq-Nächten in der Āvāzī-Form ohne Metrum gesungen:

1. yārānlär mänäm fäqīr o bīčāra

1. Ich bin elend und arm, hört zu, Yārān.

2. gäzäräm tā billäm därdıma čāra

2. Ich suche nach einem Heilmittel für meinen Schmerz.

3. Yār1 Häq gormišuq Ḥäqdur bīgümān

3. Wir erkennen Yār (Xāvändıgār) als die Wahrheit an. Er ist zweifellos die Wahrheit.

4. onunčun gälmišuq därda tīmāra

4. Seinetwegen sind wir hier, um das Heilmittel für unseren Schmerz zu suchen.

5. kim k1 Yār yoluna virsa bir Ĵovz

5. Derjenige, der dem Yār einen Jouz (Muskatnuss) widmet,

6. Jovzını yazallar ovlī Kırdāra

6. Wird als der beste Ritualteilnehmer angesehen.

7. Xōjämm hıč qulovı sän šäkka salma

7. Mein Herr, lass bitte bei keinem deiner Diener Zweifel zu.

\footnotetext{
${ }^{89}$ Šähsävāra ist einer der Namen Dāvūds und wörtlich heißt „gewandter Ritter“.
} 
8. götörub mıhrovi qoyma āvāra

9. ḥısābin alullar ${ }^{`} 11 \mathrm{~m}$ oxuyandan

10. nıj̄äh k1 Mänṣūrı čäkdılär Dāra

11. bizi fäqīr bilub qäṣda gälurlär

12. bizda päna gätürmišuq 0 Šähsävāra ${ }^{89}$

13. Quščioġlı oxur däftär āyähsin

14. günāhin ‘ärẓ eylär Xāvändıgāra
8. Mein Herr, nimm bitte deine Liebe deinem Diener nicht weg und mach ihn nicht heimatlos.

9. Die Mullāhs begleichen deine Rechnung,

10. So wie sie Mänșūr (Hällâĵ) aufhängten.

11. Diese (Mullāhs) zählen uns zu den Elenden und greifen uns an.

12. Wir suchen Schutz bei Dāvūd dem Ritter.

13. Quščığlı liest Verse aus dem Heft.

14. Er trägt seine Sünden Xāvändıgār vor.

Im Anschluss an dieses Kälām tritt ein anderer Čäp-i däst auf:

1. yā Xāvänıgār yād eyla bizi götör pärdähni šād eyla bizi

2. bända günähkār yād eyla bizi Xōjäm kärämdār šād eyla bizi
1. Du Xāvändıgār, erinnere dich an uns, nimm deinen Vorhang weg und mach uns fröhlich.

2. Wir sind sündig, erinnern dich an uns, du bist unser Herr, du bist barmherzig, mach uns fröhlich.

Die dritte Aufnahme beinhaltet ein besonderes Čäp-i däst, das im Hintergrund eines SoloGesanges im Chor gesungen wird und 20 Minuten dauert. Dieses Čäp-i däst gehört ebenfalls in das Dāvātlog-Fest, in seine letzte Nacht, in das Šāhī-Fest. Das Čäp-i däst hat eine entwickelte musikalische Struktur: es beginnt in Näġmeh-e Äfšārī, im 2/4 Takt, steigt in ein anderes Zitat von Näġmeh-e Äfšārī um und gipfelt in der Nävā-Tonart, im 4/4 Takt und in sehr hohem Tempo - über 190. Die folgenden Zeilen werden als Refrain wiederholt:

1. `Älī ‘ Älī Hū Hū mövlām `Älī Hū Hū

2. Sulțān sär Jäm Hū Hū șāḥı käräm Hū Hū
1. `Älī, ‘ $\mathrm{A} l \overline{1}$ ist Er, Er. Mein Herr ist `Älī, Er, Er.

2. Der König, das Haupt vom Jäm, Er, Er, ist Barmherzig, Er, Er.

Im Hintergrund wird ein Kälām von einem Kälām-Sänger als Solo mit Tanbur-Begleitung gesungen. Dieses lässt sich wegen der schlechten Qualität der Aufnahme und der Störungen im Hintergrund wie z. B. ekstatisches Weinen oder Schreien nicht wiedererkennen. Die sehr 
hohe Spannung im Raum und eine deutlich gestiegene Aufregung der Gläubigen im JämXāna ist für den Hörer aber gut zu erkennen. 


\section{Transkriptionen und Übersetzungen}

Kälām Nr. $1^{90}$

1. günähkāräm käräm kānı sän mänı Yāra bag̉ušla

2. Bınyāmīnilän qurulan Šärṭ o Iqrāra bag̉ušla

3. Sulțānun gizlin sırrına bäḥr-1 bīpāyān ämrına

4.Yārıstānun Kırdārına Dāvūd-1 nāzdāra bag̉ušla

5. uydurma dunyā gämına salma dudıllär ičina

6. Pīr Mūsīnun qälämına Müsțäfā qähhāra bag̉ušla

7. sıġındom sän täkın dūsta hıč äl yoxdor älın usta

8. Ručyār-1 zıbärdästa Yār Yādıgāra bag̉ušla

9. `ālämı saldun oyuna kāfırlärı gätdun dīna

10. Qul Välī günähkārı Xıdmät-1 Räzbāra bag̉ušla

1. Ich bin ein Sünder. Du bist die Quelle der Großmütigkeit.

Verzeihe mir des Freundes der Wahrheit wegen,

2. Begnadige mich wegen der entstandenen Šärț und Iqrār Bınyāmīns.

3. Vergib mir wegen des verborgenen Geheimnisses des Sulțāns ${ }^{91}$, seines Befehls, welcher dem grenzenlosen Ozean ähnelt.

4. Verzeihe mir wegen der Rituale Yārıstāns und des geliebten Dāvūds.

5. Täusche nicht die Betrübnis der Welt. Wirf mich nicht in die Menge der Zweifler hinein.

6. Des Griffels (der Feder) von Pīr-Mūsī und des zornigen Muṣțäfās wegen begnadige mich.

7. Ich sehne mich nach einem Freund ${ }^{92}$, welcher deine Eigenschaften trägt, es gibt keine Hand auf deiner Hand (es gibt keinen Mächtigen außer dir).

8. Verzeihe mir des heldenhaften herrschenden Rūčyārs, wegen des Freundes der Wahrheit Yādıgār,

\footnotetext{
${ }^{90}$ Das Nummerieren der Kälāmāt bei Säyyed Kāżem Nīknežād erfolgt - wie es in der iranischen Ghaselendichtung üblich ist - nach dem persischen Alphabet: Es wird die letzte Buchstabe der ersten Zeile berücksichtigt.

${ }^{91}$ Sulțān ist Sulțān Saḥāk, der im Weiteren auch „mein Herr“, „König“, „König der Welt“ oder „Xāvändıgār“ (Gott) genannt wird

${ }^{92}$ Freund, Freund der Warheit oder Yār - ein Yārıstān-Angehöriger.
} 
9. Du hast das Universum in das Spiel geworfen, die Heiden hast du zum Glauben geleitet!

10. Verzeihe dem Sünder Qul Välīi3 wegen der X1dmä $t^{94}$ von Räzbār ${ }^{95}$.

${ }^{93}$ Qul Välī - der Name des Kälāmsdichters.

${ }^{94}$ Xıdmät heißen alle Aufgaben, die mit dem Ritual der Zubereitung, und dem Speisen im Jäm in Verbindung stehen. Für diese Taten sind die Frauen zuständig. Rämzbār beaufsichtigt diesen Prozess.

${ }^{95}$ Pāk-e Räzbār, Pāk-Rämzbār, Pāk-Ärazbār sind die Namen für Sulțāns Helferin Rämzbār. 


\section{Kälām Nr. 2}

1. Yārānlär gälun varalum Šāha

2. ṣubḥ o šām yalvaraq qädīm Allāha

3. pīrlik usta Pīrlär dä vī eylädı

4. Pīr hā Bınyāmīnidı gečdı govāha

5. doġsanmin gulāma näżär eylädı

6. Dāvūd Dälīl oldı saldı bu Rāha

7. izini izlädı 'Ommāna daldı

8. üzuni görstädı däryāda māha (māhī)

9. Yārānlar ešidun Quščıg̉lundan

10. Yār därı Q1blähdur gälin țävāfa

1. Kommt ihr Freunde der Wahrheit, lässt uns gemeinsam zum König gelangen.

2. Lässt uns morgens und abends den ewigen Gott anflehen.

3. Die Führenden beanspruchten, die Führer zu sein,

4. Der größte Führer war der Pīr-Bınyāmīn, der zum Führer von Gott ernannt wurde.

5. Er (Gott) schaute den neunzigtausend Jünglingen zu.

6. Dāvūd wurde der Leiter und folgte diesem $\mathrm{Weg}^{96}$.

7. Eine Spur kam von ihm und er tauchte ins 'Ommān”,

8. Er zeigte sich im Meer als Fisch ${ }^{98}$.

9. Freunde der Wahrheit, hört Quščıg $11^{99} \mathrm{zu}$ :

10. Das Tor zum Freund der Wahrheit ist die Gebetsrichtung, kommt und geht um es (das Tor) herum.

\footnotetext{
${ }^{96}$ „Weg“" heißt der Yarıstān-Glaube.

${ }^{97}$ Ommān ist das Meer im Süd-Iran. In der iranischen Mythologie bedeutet es eine Bucht des größten Meers auf der Welt, das Färāxkärd heißt (vgl. Bahar 1996, S. 122).

${ }^{98}$ Es geht um die Verkörperung Sulțān Saḥāks in einen Fisch in der Yā-Ära.

${ }^{99}$ Quščloğl $l_{1}$ - der Name des Dichters dieses Kälāms.
} 


\section{Kälām Nr. 3}

1. män bu säfära varuram dörrli mäțāelär almaqa

2. täkäbburı tärk edub sālūsloqı salmaqa

3. män bu Jämin golāmeyam härnä dısa färmāneyäm

4. Sulțāndän buyurduq olob gälmišäm Däftär almaqa

5. ḥırṣ o hävānı tärketdum Äränlär dedıgin dutdom

6. älfenäfs däg1läm gälmišäm porbār olmaqa

7. Sulțān Šährına varuram șärrāfuna yalvaruram

8. tökmišäm xūrdaforūši lä'lidän Göhär almaqa

9. Quščığl1 bändähdor färmāndädor

10. Kä`bähya gälubdor țävāf-1 yäksär olmaqa

1. Ich schließe mich dieser Reise an, um die perlenartigen Waren zu kaufen,

2. Um den Hochmut aufzugeben, die Heuchelei abzuwerfen.

3. Ich bin ein Sklave dieses Jäms, ich gehorche allem, was es (Jäm) mir befiehlt,

4. Ich bin hierher gekommen auf Befehl Sultāan (Sahāaks), um die Hefte (Reden) zu bekommen.

5. Ich habe mich von der Habsucht losgesagt, ich habe die Reden von den Sieben Wesen übernommen,

6. Ich bin kein Tausender-Ego ${ }^{100}$, ich bin gekommen, um Weisheit zu erlangen.

7. Ich komme in die Stadt des Königs, ich flehe seinen Prüfer ${ }^{101}$ an.

8. Ich habe den Kleinwarenhandel aufgegeben (die wertlose Welt), um die edelste Perle zu kaufen (die reine Wahrheit zu erreichen).

9. Quščığlı ist ein Knecht und stellt sich unter Befehl Sulțāns,

10. Er (Quščıġl1) ist zur Kaaba (Jäm) gekommen, um den vollständigen țävāf (Rundlauf) um sie zu vollziehen.

\footnotetext{
${ }^{100}$ Unter „Tausender-Ego“ versteht die orientalische Literatur jemanden, der sehr gierig ist und viele unangemessene Wünsche hat.

${ }^{101}$ Der Kenner, der mit dem Prüfstein das Reine vom Falschen sortiert.
} 


\section{Kälām Nr. 4}

1. bir Gün ola Sulțānımiz Xān ola

2. jumla ${ }^{` a}$ läm hökmına färmān ola

3. bārgāhın qura bu zämīn üzüna

4. čox inanmäynlär bāeīmān ola

5. bir üzün görsäda Ähl-1 Tovhīda

6. nāgāhdan barčäsı Ovrāmān ola

7. äṣl äṣla geda väṣl väṣla

8. Nīmrūz qalub ṣāḥıb-1 meydān ola

9. zemestānı vera ävväl-1 gärmyāna

10. yavuqdor pīrlär qovli bäyān ola

11. Äränlär boyuna bičildı Xäl ät

12. bir nečäsı qalobdor nämāyān ola

13. yāranlärıčun bir gün dog̀a

14. o günda därdlärına därmān ola

15. kimı yükün dutmuš ola räḥmätdän

16. kimisı Qapuda bīsāmān ola

17. Quščığlı deyır yeq1lın yārān

18. nīmsāeät qalur Xōjäm Dīvān ola

1. Käme bloß ein Tag, an dem Xān Äḥmäd ${ }^{102}$ unser König wäre!

2. An dem sein Befehl die Welt gänzlich beherrschte,

3. An dem sein Audienzsaal auf dieser Erde stünde,

4. An dem viele Heiden gläubig würden!

5. Wenn er bloß sein Gesicht den Gläubigen zeigen würde,

6. Wenn er sich plötzlich einmal in Hovrāmān befände,

7. Hätte jeder seinen Ursprung erreicht und der Geliebte hätte sich mit seinen Anhängern vereinigt.

8. Die Mittagssonne ${ }^{103}$ würde bleiben und würde alles beleuchten.

9. Der Beginn des Sommersitzes ${ }^{104}$ hätte den Winter abgelöst!

\footnotetext{
102 Xān Äḥmäd - ein weiterer Körper von Šāh Ibrāhīm. Xān Äḥmäd ist der Gründer einer Yārıstān-Xānıdān.

${ }^{103}$ Die Mittagssonne oder der Rapithwin ist der Herr der Mittagswärme und Herr der Sommermonate, d.h der Herr der idealen Welt (vgl. Hinnells 1975, S. 43).

${ }^{104}$ Der Sommersitz ist dasselbe wie ,die Mittagssonne“.
} 
10. Bald würden die Reden vom Meister verkündet,

11. Es würde für die Sieben Wesen das Ehrenkleid maßgeschneidert.

12. Einige sind weggeblieben, aber werden jetzt erscheinen.

13. Ginge bloß ein Tag für die Freunde der Wahrheit auf,

14. Es gäbe an diesem Tag ein Heilmittel für ihre Wunden!

15. Es gäbe manche, die ihre Last von der Gnade übernommen hätten,

16. Während andere heimatlos vor der Tür laufen.

17. Quščığlı sagt: versammelt euch, Freunde der Wahrheit!

18. Es bleibt eine halbe Stunde, bis mein Herr zum Dīvān (obersten Richter) wird. 


\section{Kalām Nr. $5^{105}$}

1. ilāhī Yārı sän Yārdan ayurma

2. Yārı dīn o imāndan ayurma

3. ilāhī sän gülsän män säna bülbül

4. ilāhī bübülı güldän ayürma

5. ördägın mäskäni göldor gölsiz dirilmäz

6. ilāhī sän onı göldän ayurma

7. baloqun mäskäni sudur susuz dirilmäz

8. ilāhī sän onı sudan ayurma

9. bügün särv aqâ̂1 bostān ičinda

10. ilāhī särvı bostāndan ayurma

11. yaradan arını häm šānı sänsän

12. ilāhī sän onı šāndan ayurma

13. āhūnun mäskäni čöldor čölsuz dirilmäz

14. ilāhī sän onı čöldän ayurma

15. Ṭāyfanın mäkāni Jämdor Jämsiz dirilmäz

16. ilāhī Ṭāyfanı Jämdän ayurma

17. Quščığlı quldor Dīvāndan gälür

18. ilāhī hıč qulun Dīvāndan ayurma

1.O, Gott! Trenne bitte die Wahrheit nicht von den Freunden der Wahrheit!

2. Trenne bitte die Freunde der Wahrheit nicht vom Glauben und von der Religion!

3. O, Gott! Du bist die Blume und ich bin deine Nachtigall.

4. O, Gott! Bitte trenne die Nachtigall von der Blume nicht ab!

5. Der Teich ist die Behausung der Ente. Sie lebt ohne Teich nicht.

6. O, Gott! Trenne bitte die Ente vom Teich nicht ab!

7. Das Wasser ist die Behausung des Fisches, ohne Wasser lebt er nicht.

8. O, Gott! Trenne ihn bitte vom Wasser nicht ab.

9. Heute steht die Zypresse im Garten.

10. O, Gott! Trenne sie bitte vom Garten nicht ab.

11. Du erschaffst sowohl die Biene als auch das Wachs.

12. O, Gott! Trenne sie bitte vom Wachs nicht ab!

\footnotetext{
${ }^{105}$ Durch diese Rede wurde die Einheit des Menschen mit der Natur gezeigt. Quščıoġlı betet den Sulțān, dass er die Einheit weiter beschützte.
} 
13. Das Reh hat die Behausung in der Steppe. Es lebt ohne Steppe nicht.

14. O, Gott! Trenne es bitte von der Steppe nicht ab!

15. Der Ort des Ṭāyfa ist das Ĵäm-Xāna. Er (der Ṭāyfa-Gläubiger) lebt ohne Jäm nicht.

16. O, Gott! Trenne ihn bitte vom Jäm nicht ab!

17. Quščioqlı ist der Knecht. Er kommt aus dem Dīvān (Gerichtshof Gottes).

18. O, Gott! Trenne bitte keinen deiner Knechte vom Dīvān ab! 


\section{Kälām Nr. 6}

1. bu geĵa d1lxurām oldum mübāräk šäb mübāräk šäb

2. gäämım getdı bīgäm oldum mübāräk šäb mübāräk šäb

3. gögdän yera čırāg ändı Doldolınän Burāq ändı

4. Ähl-1 Ḥäqqa tıfāq ändı mübāräk šäb mübāräk šäb

5. čırāg o xuršīid o māhı zämīn o āsımān bārgāhı

6. ačuqdur dıläkä därgāhı mübāräk šäb mübāräk šäb

7. mänım äyäm bīnäżīrdor jämī yerlärdä ḥāzırdor

8. bu gejäh `Yd-1 Qādırdor mübāräk šäb mübāräk šäb

9. üyüb barčäh xälāyıqlär oyaqdur Ḥäqqa lāyıqlär

10. xıdmätdadur mälāyıklär mübāräk šäb mübāräk šäb

11. `Äršin morg̀idor bānlar väqtilän sāe äti anlar

12. Xōjäm bilor nolur danlar mübāräk šäb mübāräk šäb

13. Quščığlı šäb1 ötdi ` Äršin morg̀ı bān etdi

14. yäqīn billäm ki Dān ötdi mübāräk šäb mübāräk šäb

1. Diese Nacht bin ich froh geworden, es ist eine gesegnete Nacht! Es ist eine gesegnete Nacht!

2. Mein Gram ging weg und ich wurde sorglos, es ist eine gesegnete Nacht, es ist eine gesegnete Nacht.

3. Es kam das Licht (Sulțān Sähāak) vom Himmel auf die Erde. Mit dem Doldol ${ }^{106}$ stieg Boragh ${ }^{107}$ herunter.

4. Die Freunde der Wahrheit vereinigen sich. Es ist eine gesegnete Nacht, es ist eine gesegnete Nacht.

5. Das Licht, die Sonne und der Mond, die Erde und der Himmel sind alle sein (Sulțān Säḥ̄aks) Hof.

6. Seines Hofes Tor ist offen für alle, die sich nach ihm sehnen.

Es ist eine gesegnete Nacht! Es ist eine gesegnete Nacht!

7. Mein Herr (Sulțān Säḥāk) ist einzigartig, er ist überall anwesend.

8. In dieser Nacht findet das größte Fest von Yārıstan statt.

Es ist eine gesegnete Nacht, es ist eine gesegnete Nacht.

9. Alle Menschen schlafen, nur die Leute, die der Wahrheit

\footnotetext{
${ }^{106}$ Der Name des Pferdes von ${ }^{e} \ddot{A} l \overline{1}$, (der Schwiegersohn Muhammads) des Moslemführers.

${ }^{107}$ Der Name des Pferdes von Muhammud dem Propheten, mit dem er eine Himmelfahrt gemacht hatte.
} 
würdig sind, sind wach.

10. Die Engel stehen zu Diensten, es ist eine gesegnete Nacht, es ist eine gesegnete Nacht.

11. Der Hahn des Throns ruft pünktlich und teilt den Menschen die Zeit mit,

12. Mein Herr weiß, was Morgen kommen wird, es ist eine gesegnete Nacht, es ist eine gesegnete Nacht.

13. Quščioql1, pass auf! Der Hahn des Throns krähte, dass die Nacht vorbei geht.

14. Ich bin sicher, dass Venus unterging. Es ist eine gesegnete Nacht, es ist eine gesegnete Nacht. 


\section{Kälām Nr. $7^{108}$}

1. Ĵān odur gözına jāānān göronöb

2. göylinün gözına bir jāan göronöb

3. göylun arodub gärd o gübārın

4. ö pīrınin sırrı älvān göronöb

5. čūn Muhämmäd vardı Häẓrät qaposuna

6. Šärïät Ṭärīqät vạ Häqīqät doqsan göronöb

7. ottoz min saxlandı ‘ Älī sırrinda

8. atmuš minı Muhämmäda ärkān göronöb

9. nāšs̄ xälāyıq deyällär Tari handadur

10. Șıdqilän qurı aqaĵa baxsan göronöb

11. qapoya gälub Yār diläriz ičärı girmäz

12. önün gözına šäkkila gömān göronöb

13. sözini sölär rāzilän hämrāh dägil gämmāzilän

14. hämrāz dägil Šähbāzilän gözınäh Qırān göronöb

15. yıgāna qul olan xıdmät eylädı pīra

16. beyla ki täxt-1 dovlätda sulțān göronöb

17. Quščıog̉ınun yeddı jäddi barča gūyända

18. özı döst1län ičmiš äsräk mästān göronöb

1. Die lebende Seele ist jemand, vor dessen Augen der Geliebte erschienen ist,

2. Vor den Augen seines Herzens ein Geliebter erschienen ist.

3. Er säuberte sein Herz von Staub und Nebel,

4. Um das Geheimnis seines Lehrers glänzend und bunt zu sehen.

5. Weil Muhammad ${ }^{109}$ am Tor Gottes gewesen war,

6. Wurden Schari'ät und Tarīqät ${ }^{110}$ und die Wahrheit als neunzig (Tausend) gesehen.

7. Dreißigtausend ${ }^{111}$ sind das Geheimnis für $\mathrm{Ali}^{112}$ geblieben.

8. Sechzigtausend davon sind für Muhammad als Grundlage festgestellt.

9. Die Unwissenden fragen: „Wo ist Gott?“

\footnotetext{
${ }^{108}$ Dieses Kälām spielt auf die Himmelfahrt von Muhammad ein. In der Nacht sagte Gott zu Muhammad die neunzigtausend Worte. Gott befahl ihm, dass dreißigtausend davon geheim bleiben und die übrigen der Allgemeinheit gesagt werden.

${ }^{109}$ Der Prophet.

${ }^{110}$ Der Weg eines Sufis, worauf er mit Gott Eins werden kann.

${ }^{111}$ Die „Dreißigtausend“ sind die Wahrheitsgeheimnisse. Andere „Sechzigtausend“ sind Schari’ät und Tarīqät.

${ }^{112}$ Der Schwiegersohn Muhammads.
} 
10. Wer ehrlich auf das trockene Holz ${ }^{113}$ schauen würde, dem würde er sich zeigen.

11. Der Freund der Wahrheit ist an das Tor ${ }^{114}$ gekommen, wir bitten ihn, hereinzukommen, er tritt aber nicht herein.

12. Er ist verzweifelt und verdächtig (in seinen Augen ist Verzweifelung und Verdächtigung zu sehen).

13. Er drückt seine Worte geheimnisvoll aus, er vertraut dem Verleumder nicht.

14. Er vertraut dem Königsadler nicht (in seinen Augen ist „q1ran“"115 zu sehen).

15. Er diente dem Pīr so einzigartig wie kein anderer,

16. Dass er (der Diener) sich wie ein König auf dem Regierungsthron fühlte.

17. Alle sieben Väter (Generationen) von Quščıg̉lı sind Dichter,

18. Er hat mit seinen Freunden getrunken und sieht betrunken aus.

\footnotetext{
${ }^{113}$ Die Zeile weist auf die Geburt Bābā Yādıgārs hin.

${ }^{114}$ Das Tor führt zu Gott.

${ }^{115}$ Zwei Himmelskörper in einem Tierkreiszeichen (als astrologisches Vorzeichen).
} 


\section{Kälām Nr. 8}

1. öl gün ola Yār gäla yanoma yā räbb

2. Yārdan gäyri nä yār ärär ĵānoma yā räbb

3. Döstičün mäšğūläm hā intīżāräm

4. nä ola Döst gäla mihmānoma yā räbb

5. därdlı qalmišam zämānäda därmān äla gälmäz

6. nä yaxšıdur därdımın därmānuna yā räbb

7. yer o göga sig̀mäz čoxdor günāhöm

8. nä qulloqa yararam Sulțānöma yā räbb

9. geĵalär yata bilmäm xōb ičinda

10. räḥmun gälsün dīdeh-1 giryānöma yā räbb

11. Isma‘'il täk Heäqqin yolünda täslīm

12. gögdän gözäl qoč gäla qurbānoma yā räbb

13. Quščıg่lınun göylüna göra ver gäl mürādın

14. lüṭf eyläg1län yārila dövrānoma yā räbb

1. Käme bloß an meinem Todestag der Geliebte (Freund der Wahrheit) zu mir, oh Gott!

2. Welcher andere Freund würde zu mir kommen außer ihm, oh Gott!

3. Seinetwegen mache ich mir Sorgen und auf ihn warte ich immer weiter.

4. Wie wäre es, wenn der Freund zu mir zu Besuch kommen würde, oh Gott!

5. Voll Schmerzen bin ich in meinem Leben geblieben, und kein Heilmittel finde ich.

6. Wie gut es wäre, wenn er die Heilung meiner Schmerzen würde, oh Gott!

7. Die Erde und der Himmel können meine Sünden nicht tragen, sie sind so viele.

8. $\mathrm{Zu}$ welchem Dienst tauge ich meinem König, oh Gott!

9. Nachts kann ich nicht schlafen.

10. Ich bitte um Gnade für meine schlaflosen verweinten Augen, oh Gott!

11. Wie Ismail ${ }^{116}$ kapituliere ich auf dem Wege Gottes.

12. Käme bloß der hübsche Schafbock statt mir als Opfer, oh Gott!

13. Komm, bitte! Und verwirkliche die Wünsche des Quščığl1,

14. Habe Gnade mit deinem Freund und seiner Ära, oh Gott!

\footnotetext{
${ }^{116}$ Ismail ist eine von mehreren verschiedenen Manifestationen (Körpern) von Bābā Yādıgār.
} 


\section{Kälām Nr. 9}

1. Yārānlär mänäm bīčāra ḥäsrät

2. gövnöm ag̉lar gıčär o Yāra ḥäsrät

3. gaärībäm sūxtähäm jāayom zımıstān

4. zämhärīrda qalmišäm bahāra ḥäsrät

5. yāräbb bu šährda tạ̈bīb varmi ola

6. därdımı qayıtdır tīmāra hääsät

7. dur äy nä yatubsän Mäĵnūn-i xästäh

8. ki Leylī sarıdän Xäbāra ḥäsrät

9. Šeyxī Jān dilägin yārılän olsun

10. münājāt eyläräm dīdāra hạäsät

1. Meine Freunde! Ich bin hilflos, ich bin traurig.

2. Aus Sehnsucht weine ich, wenn ich an dem Freund der Wahrheit vorbei gehe.

3. Ich bin heimatlos, ich bin leidend, mein Standort ist der kalte Winter.

4. Ich bin in der strengen Kälte geblieben, ich sehne mich nach Frühling.

5. Oh, Gott ! Wenn bloß in dieser Stadt ein Arzt wäre,

6. Der meine Schmerzen behandeln würde!

7. Wach auf! Warum schläfst du, der verletzte Madjnun ${ }^{117}$,

8. Der aus Liebe zu Leyli sich nach einer Nachricht sehnt.

9. Šeyxī Ĵān, ${ }^{118}$ dein Anliegen soll sein, mit dem Freund zusammen zu sein.

10. Ich flehe und ich sehne mich, ihn zu treffen.

\footnotetext{
${ }^{117}$ Als Madjnun (,Wahnsinniger“) wird im Orient ein Verliebter genannt. Diese Tradition stammt aus dem Werk Nizamis ,Leyli und Madjnun“.

${ }^{118}$ Der Dichter dieses Kälāms.
} 


\section{Kälām Nr. 10}

1. gäl ey färyādräs färyādıma yet

2. ḥokomlı padıšahsän dādıma yet

3. müškk1 išim düšüb sänı čaqörram

4. yā ‘äzīz Xāvändıgar hävārıma yet

5. Hoĵūm dönilän čixdün jähāna

6. Hoĵūmün sovušdür färyādıma yet

7. günähkār qullärdän gäldı Qapova

8. yā Šāh Ibrāhīm imdādıma yet

9. Āqāoġlı özi üsta düšüb günāhün dilär

10. günähkār qulindor günāhundan öt

1. Komm, du Helfer, hilf mir, bitte!

2. Du bist der Gebieter, König, komm mir zu Hilfe, bitte!

3. Wenn ich von einer schweren Not betroffen bin, rufe ich dich an.

4. Oh, lieber Gott! Komm mir zu Hilfe, bitte!

5. Durch das Ertönen von Hojus ${ }^{119}$ Posaune kamst du zur Welt.

6. Erkenne mich an durch die Bestätigung Hojüms! Komm mir zu Hilfe, bitte!

7. Einer der Sünder-Diener kam an dein Tor,

8. Oh! Šah Ibrahīm! Komm mir zu Hilfe, bitte!

9. Ăqāog̉ $11^{120}$ wirft sich zu Boden, er bekennt selber seine Sünde.

10. Er ist dein sündiger Sklave, verzeihe ihm bitte!

\footnotetext{
${ }^{119}$ Hoju ist eine andere Inkarnation von Dāvūd (einem der Sieben Wesen). Er ist hier mit dem Engel Esrafil vergleichbar.

${ }^{120}$ Der Dichter dieses Kälāms.
} 


\section{Kälām Nr. 11}

1. dägma kiši șūfĩ olmaz sīnähsinün șāfı yox

2. älını müršıda vermiš göylonün insāfi yox

3. älını müršıda vermiš dıdigin dutmamüš

4. xıdmätı qäbūl mi olur čūn pīrindän xāfı yox

5. bir kiši ki öz pīrını Beytollāh bilmäsa

6. qaranqoloq dama bängzär tı̂̄îr o țänāfi yox

7. bir kiši ki Häâjja vara xūyını dägišmeya

8. Mäkkäya varmušĵa var Kä‘bäya țävāfi yox

9. didilär Quščıġlona sözüvün lāf etma gäl

10. Häqqda bilur ki sözömun lāfi yox iẓāfi yox

1. Eine Nichtigkeit (ein kleiner Mensch) wird nie ein Sufi, weil er kein reines Herz hat.

2. Er reicht seine Hand einem Morsched ${ }^{121}$ (er erkennt einen geistlichen Führer an), aber in seinem Inneren gibt es keine Gewissenhaftigkeit.

3. Er reicht seine Hand einem Morsched, ohne das eigene Versprechen zu halten.

4. Wie kann sein Dienen akzeptiert werden, wenn er keine Gottesfurcht vor seinem Pīr hat.

5. Derjenige, der seinen eigenen Pīr nicht als Gotteshaus (Mekka) anerkennt,

6. Ähnelt einem dunklen Zimmer, das weder Fenster noch Klappfenster hat.

7. Derjenige, der nach Mekka geht, ohne sein Wesen zu verbessern,

8. Ist nachher in Mekka gewesen ohne einen Rundgang um die Kaaba gemacht zu haben.

9. Viele sagten Quščıġlı: "Komm, bitte, prahle nicht".

10. Gott selbst weiß, dass ich weder prahle noch übertreibe.

\footnotetext{
${ }^{121}$ Morsched ist ein geistlicher Führer der Sufi und ist mit einem Pīr der Yārıstān vergleichbar.
} 


\section{Kälām Nr. 12}

1. ġärībäm bu täräflärda bulumĵa säviki yārom yox

2. saraldı bīgāayät rängım härgiz ḥālımı soranom yox

3. gäāībäm täšnäyäm zāräm bilunmäz därdima čāräh

4. yüz dutub Häqqa yalvarram mundan özga hıč čārom yox

5. ‘äzīz bizdän iraq oldı ĵ̣ıärim yandı dāg oldı

6. jäm̄̄ ĵismim käbāb oldı șäbr ẹvinda qärārom yox

7. väṣl-1 jāanāndän ayroldom bagiır basdom ṣäbır q1ldım

8. xāṭırlär ävliyā gäldim mundan artox gözārom yox

9. ovlī Sulțānoma qulam näčün diyäräm yoxsolam

10. pādıšāhum gänĵındän artox yarum aqča dīnārom yox

11. Bäğdāddän Täbrīza vardom särmāyämda Ḥäqq1 bildom

12. ag̉or bāzärgānlär kimi tänbälit kār o bārom yox

13. män sänı sövdöm sän mänım häbīb o yārom olasan

14. alomom verımım Ḥäqqdor bāṭ1lilän bāzārom yox

15. yārānlär därdlı qaldom därdıma därmān bilmädom

16. Dälīl o Täkbīrdän artox mänım därda tīmārom yox

17. Ibrāhīm Quščıg̉lını sän saldun hiĵrān otona

18. gänä da baxarom sän sän sändän özga baxarom yox

1. In dieser Umgebung bin ich heimatlos, da ich keinen geliebten Freund der Wahrheit finden kann.

2. Mein Gesicht ist endlos blass, keiner interessiert sich für mein Dasein.

3. Ich bin heimatlos, ich bin durstig, ich bin jammernd. Für meine Schmerzen wird es kein Heilmittel geben.

4. In die Richtung der Wahrheit gehe ich flehentlich - außer dieser habe ich keine andere Möglichkeit.

5. Der Geliebte (Sulțān Säḥāk) ist weit weg, meine Leber (mein Herz) brennt und ist glühend heiß geworden.

6. Mein Körper ist gänzlich verbrannt. In der Sesshaftigkeit der Geduld habe ich keine Ruhe.

7. Ich lebe von meinem Geliebten getrennt, ich verberge mein Leiden, ich leide.

8. In meiner Vorstellung trat ich an die Stelle des Regenten (Sulțān Säḥāk), 
mehr Möglichkeiten habe ich nicht.

9. Weil ich der Diener meines hochwertigen Königs bin, rechne ich mich nicht als arm:

10. Meinem König zu dienen ist ein Schatz, neben dem ich keine Halbgoldmünze mehr brauche.

11. Ich ging von Bäğdād nach Tabrīz ${ }^{122}$. Ich wusste, dass die Wahrheit mein einziges Kapital ist.

12. Ich habe keine große Satteltasche voll von Goldmünzen, wie die reichen Kaufmänner haben.

13. Ich bin in dich verliebt. Ich wünsche mir, dass du mein Geliebter und mein wahrer Freund wirst.

14. Mein Handel ist die Wahrheit. Ich habe mit der Eitelkeit nichts zu tun.

15. Ich bin voll Schmerzen geblieben. Ich habe kein Heilmittel für meine Schmerzen. Wisst Bescheid, ihr Freunde der Wahrheit,

16. Dass ich außer den „Dälīl o Täkbīr“'123 für meine Schmerzen keine Pflege habe.

17. Du (Freund der Wahrheit) warfst den Ibrāhīm Quščığlı in die brennende Trennung von den Freunden.

18. Du bist immer weiter meine Hoffnung, außer dir habe ich keine andere Hoffnung.

${ }^{122}$ Diese Passage spielt auf die Heilung Quščığlıs bei Šāh Ibrāhīm in Bäğdād ein. Mehr dazu siehe im Kapitel II.1.1.

${ }_{123}$ „Dälīl o Täkbīr“ ist das Segnen im Ĵäm unter der Aufsicht von Bınyāmīn und Dāvūd. 


\section{Kälām Nr. 13}

1. lovḥindäh yazolmuš sä ādätlı baša bax

2. āhila sīnäm yanar ' išqila ātäša bax

3. Tä'ālällāhun āyähsı xūblarun väjhindador

4. āyähya gäläț mi baxan o qälb qumāša bax

5. ‘ähd o peymān eylähdun ki sırrımı saxlıyasän

6. eylähdun xälqa bärmälā' o sırrı sırrıdaša bax

7. ayilän gün bir oldı doġdı Mohämmädä nūrı

8. nābālıg hilāla bängzär șūrätinda qaša bax

9. bir gaärībdän išıtdom dıl niyāz itdom bügün

10. gözlärimdän Ĵeyḥūn axar bu tükänmäz yaša bax

11. gäl äy ostād-1 bātä' līm munĵa șänāeät sändador

12. lā̂̂1värddän yaslanmiš bünyād-1 näqqāša bax

13. kāfır o tärsā o jühūdın yazoq1 gälur mäna

14. mudda īnun bag̀nı qan bu ärimäz daša bax

15. kim ki ičdi Quščıg̉ lı ičdiki peymānähdän

16. bīzävāl oluban `omri bu tükänmäz yaša bax

1. In deinem Schicksalsbuch steht, dass du einen glücklichen Kopf $\mathrm{K}^{124}$ hast!

2. Mein Herz brennt in feurigen Seufzern. Schau dir die flammende Liebe an.

3. Gott schickte seine Verse, um hübsche Gesichter zu beschreiben.

4. Wie kann ein Vers Gottes falsch verstanden werden? Wenn einer so tut, ist er ein Betrüger. Pass auf, dass du nicht zu einem solchen wirst.

5. Du hast versprochen, mein Geheimnis zu bewahren.

6. Du hast aber dein Wort nicht gehalten und mein Geheimnis öffentlich gemacht.

Es gibt neben dir viele andere, die das Geheimnis bis zum Tod bewahren.

7. Die Sonne vereinigte sich mit dem Mond, um Helligkeit für Muhammad (den Propheten) zu erzeugen.

8. Guck auf die Augenbrauen in deinem Gesicht, die dem neuen Mond ähneln.

9. Ich habe von einem Fremden etwas erfahren, was heute mein Herz berührte.

10. Aus meinen Augen fließen Tränen wie der Oxus (Amu-Darja).

\footnotetext{
${ }^{124}$ Hier sind Bābā Yādıgār und Hällâĵ gemeint. Als ,glücklicher Kopf“ wird bei den Yārān derjenige bezeichnet, der sein Leben für Idealen geopfert hat (siehe auch Kälām Nr. 17, 7. Zeile).
} 
Sieh diese unendlichen Tränen.

11. Komm an! Oh, du hoch gebildeter Meister, du bist solch ein Künstler, der

12. Aus umgestülptem Lasurstein die Welt begründet hat. Sieh dir den Maler (Schöpfer der Welt) an.

13. Die ärmsten der Heiden, Christen und Juden kommen zu mir.

14. Sei das Herz eines Gegners verblutet. Sieh dir den nicht schmelzenden Stein (das Herz eines Gegners ist gefühllos wie ein Stein) an.

15. Wenn jemand aus demselben Becher trinkt, aus dem auch Quščıġlı Wein trank, 16. Wird sein Leben unvergänglich. Sieh dir das unendliche Lebensalter an. 


\section{Kälām Nr. 14}

1. gāâf11 ġ giflät aparmuš üyübdor oyaq1 yox

2. özi qalmuš qaranquda čırāġınun yağ1 yox

3. '1lm oxuyan mullāläri gördöm özina bilgäm deyir

4. beyla bilgäm mi olur Häqq Dīvāndan sorāq1 yox

5. ovlī sulțānlärı gördöm tāj o täxtı buraxmuš gidär

6. ḥukmläri yürimäz olur šährinin nässāq1 yox

7. novkärlärina zutloq vermäz bašina čāräh q1lsunlär

8. üstüna yād-1 yāg̀ī gälmiš silāḥ o yärag̉ı yox

9. äbdāllär1 gördom qap1 qap1 dillänür

10. bašına jâây darolmuš hıč yerda duraq1 yox

11. qara giymiš därvīšläri gördöm särgärdān gäzär

12. pīrini tanumamuš göylünda nišān-1 dāg̀1 yox

13 Quščiog̀lı o ‘äṣrda gāafil olma zīnhār

14. Äyädän bir vä da qoymuš yavoqdor iraq1 yox

1. Ein nachlässiger Mensch schläft wegen seiner Nachlässigkeit immer weiter und wird nie wach.

2. Er selbst ist in der Dunkelheit geblieben. Seine Laterne hat kein Rizinusöl.

3. Ich sah Mullāhs, die Theologie studierten und sich zu den Weisen rechneten.

4. Wie kann man solches Wissen zur Wissenschaft rechnen? Ist es nicht genauso, als wenn die Wahrheit und Dīvān (Gerichtshof Gottes) keine Verbindung miteinander hätten?

5. Ich sah die großen Könige, die ihre Throne verließen und weggingen.

6. Ihr Befehl hat keine Gültigkeit mehr, weil es in ihrer Stadt keine Ordnung gibt.

7. Sie (die Könige) geben ihren Dienern keinen Arbeitslohn, um sich um ihre königliche Person zu kümmern.

8. Deswegen kommen sie (die Diener) auf den Gedanken, zu rebellieren, aber sie haben weder Waffe noch Ausrüstung.

9. Ich sah Heilige, die von einem Haus zum anderen gingen und bettelten.

10. Sie befanden sich in einem Engpass, worin es keinen Aufenthaltsort gab.

11. Ich sah die schwarz gekleideten Derwische, die obdachlos sind.

12. Sie (die Derwische) kennen ihren Lehrer nicht. Bei ihnen gibt es nicht die Spur der Leidenschaft. 
13. Du Quščığl1! Sei in diesem Zeitalter nie nachlässig, pass auf!

14. Der vom Herrn (Gott) bestimmte Termin ${ }^{125}$ ist nicht so weit, er ist nah.

${ }^{125}$ Unter dem „Termin“ versteht der Dichter die Apokalypse. 


\section{Kälām Nr. 15}

1. män bir därdlı dıläm kimsa mändän xäbārı yox.

2. sövläšma onilan čūnki sändän xäbārı yox

3. här kima og̉raram atar mäna țä na dašını

4. täxta otüran ovlī xānıdān xäbārı yox

5. ādämī var bu dunyāda ḥäyvānilän bärābärdor

6. täk jāān vırub väṣl-1 jāāāndan xäbārı yox

7. '1lm oxomuš mullālärı gördöm bilgäm deyir

8. beyla bilgäm mi olur Ḥäqq Dīvāndan xäbārı yox

9. bax Häqqı tanıyan Nūḥ Ṭūfānın görmadi

10. onun nä därdı var qopsa Ṭūāndan xäbārı yox

11. Muḥämmäda deyun Ḥäqīqät Sözön sovläräm män

12. o ümättı gör dadlı zäbāndan xäbārı yox.

13. İbrahīm ičirtdı Quščıg̉loni bu qädäḥdän

14. äyläh mästdor o jähāndan xäbārı yox

1. Ich bin ein schmerzendes Herz. Niemand weiß über mich Bescheid.

2. Sprich mit demjenigen nicht, der über dich nichts weiß, weil er dich nicht verstehen kann.

3. Wenn ich zu so jemandem gehe, in der Hoffnung, mit ihm vertraulich zu reden, bekomme ich nur die Steine der Vorwürfe.

4. Die adlige Dynastie, die auf dem Thron sitzt, hat keine Ahnung von meinen Schwierigkeiten.

5. Es gibt Menschen in dieser Welt, die den Tieren gleich sind.

6. Wenn ein einsamer Verliebter sich für die Liebe opfert und stirbt, erfährt er nicht, wie ist es, eine Geliebte erreicht zu haben.

7. Ich sah Mullāhs, die Theologie studierten und sich zu den Weisen rechneten.

8. Wie kann man solches Wissen zur Wissenschaft rechnen? Ist es nicht genauso, als wenn die Wahrheit vom Dīvān (Gerichtshof Gottes) keine Ahnung hat?

9. Sieh zum Beispiel, wie der fromme Noah Gottes Sintflut nicht sehen konnte.

10. Wie kann Noah Schmerzen haben, wenn er sogar von der Sintflut keine Ahnung hat.

11. Teilt ihr Muhammad mit, dass ich das Wort der Wahrheit spreche: 
12. Schau dir Muhammads Anhänger an, die vom Wort der Wahrheit keine Ahnung haben.

13. İbrāhīm (Šāh) gab Quščığlı aus einem Weinbecher zu trinken.

14. Er (Quščığli) ist so berauscht, dass er von der Welt kein Wissen mehr hat. 


\section{Kälām Nr. 16}

1. yārānlär därdli qalmuš därdina därmān Jüüneyd

2. `ālämlär yıq1lur gälür ḥukmova färmān Jüneyd

3. gün dog்ušundan gälürsän gün batušuna varursan

4. öz älivinan salursän `āläma țūfān Jüneyd

5. mäxlūq oldı jāndan bīzār ḥukmin yer o gögi gäzär

6. sän dila yārānläričün bir ovlī Dīvān Jüüneyd

7. sözün olilar mä nāsi oni bilüllar hamusi

8. bu jüumlähsi älindädor ḥukmova färmān Jüneyd

9. o boyaq ki sän boyarsän hıč boyaqčı boyamaz

10. pādıšāhom özi boyaqčıdor ränglärı älvān Jüneyd

11. Šārazūrda bārgāh qurar Pīrdävärda Dīvān durar

12. pīr o murīdin barča yıqar rähbär-1 yārān Jüneyd

13. yār Yādıgār muštāqdor jämālin görmäga

14. šükr görduq jämālun Qıbleh-1 īmān Jüneyd

1. Yārān leiden unter Schmerzen.

Jüneyd ${ }^{126}$, gegen ihre Schmerzen bist du das Heilmittel.

2. Du bist so mächtig, dass viele Welten deinem Befehl gehorchen.

3. Du kommst mit dem Sonnenaufgang, du gehst mit dem Sonnenuntergang weg.

4. Jüneyd! Du wirfst mit deiner eigenen Hand den Sturm in die Welt.

5. Alle Geschöpfe sind ihres Lebens müde. Dein Befehl herrscht überall im Himmel und auf der Erde.

6. Jüneyd! Verlange für die Freunde der Wahrheit einen prächtigen Dīvān (Gottes Gerichtshof).

7. Deine Worte und ihre Bedeutungen sind für alle Yārıstān verständlich.

8. Jüneyd! Alle sind in deiner Macht und gehorchen deinem Befehl.

9. Die Farbe, die du herstellst, gibt es sonst in keiner anderen Palette.

10. Mein König ist selbst auch ein Maler. Seine Farben sind sehr bunt.

11. Er (der König) gründet in Šārazūr seinen Königssitz. Er schafft in Pīrdävär seinen Dīvān (Gerichtshof Gottes ).

12. Er (mein König) lädt alle Lehrer und Freunde der Wahrheit ein und stellt

\footnotetext{
${ }^{126}$ Jünneyd ist eine Inkarnation von Dāvūd. Er darf nicht mit Jüneyd-e Bäğdādī verwechselt werden.
} 
Jüneyd als deren Führer ein.

13. Der Freund der Wahrheit Yādıgār ${ }^{127}$ hat Sehnsucht, dein Gesicht zu sehen.

14. Jüneyd! Dein Gesicht ist unsere Kaaba. Dank dir, dass du uns ermöglichtest, die Kaaba zu sehen.

${ }^{127}$ Der Dichter dieses Kälāms 


\section{Kälām Nr. 17}

1. ämān mürüvvätdor yetiš härāyema eyla bir mädäd

2. qoyma gämxānada mäni yetiš härāyema eyla bir mädäd

3. istäräm sändän yer o gög șāḥıbı Sulțān-1 ‘āläm

4. bag̉ušla Bınyāmīn Šärṭına yetiš härāyema eyla bir mädäd

5. bädra döndär hilāl olmuš māhımı Čärxa üz döndörsäm čäkmäz āhımı

6. baġušla Dāvūda sän günāhımı yetiš härāyema eyla bir mädäd

7. Yādıgār baš verdı Šāhına Kırdārı xošdor Häqqına

8. bag̉ušla pīr Mūsī näżärgāhına yetiš härāyema eyla bir mädäd

9. Qul Välī yalvarur räḥmätä näżär eyla bir guz̄ār

10. baġušla Rämzbār Kırdārına yetiš härāyema eyla bir mädäd

1. Ich bitte um Gnade! Ich verlange nach Edelmut, hilf mir! Ich schreie um Hilfe.

2. Verlass mich nicht im Haus der Trauer. Hilf mir! Ich schreie um Hilfe.

3. Ich verlange von dir, du König der Welt, Besitzer der Erde und des Himmels,

4. Mir zu verzeihen wegen des Paktes Bınyāmīns. Hilf mir! Ich schreie um Hilfe.

5. Verändere meinen Halbmond zum Vollmond (mach meine Schwäche zu Stärken).

Mein Seufzen ist so brennend traurig, dass das Universum es nicht ertragen kann.

6. Verzeihe mir meine Sünden wegen Dāvūd! Hilf mir bitte! Ich schreie um Hilfe.

7. (Bābā)Yādıgār opferte sich für seinen König, er freut sich über sein Ritual (seinen Opfertod) für seine Wahrheit.

8. Verzeihe mir wegen der Sichtweise Pīr Mūsīs. Hilf mir! Ich schreie um Hilfe.

9. Qul-Väli ${ }^{128}$ fleht dich um deine Barmherzigkeit an. Schenk mir bitte aus Gnade deine Aufmerksamkeit!

10. Verzeihe mir wegen des Rituals Rämzbārs. Hilf mir! Ich schreie um Hilfe.

\footnotetext{
${ }^{128}$ Der Dichter dieses Kälāms.
} 


\section{Kälām Nr. 18}

1. Xāvändıgāra Häqq baxun Ḥäqq1 sövänlär bulardor

2. sövdi yaratdı Häftäni jümlähnin xōhānı bulardor

3. jämīe sırrlärin bašı Xāvändıgārdor

4. Häaqıın söygüsi därdizin därmānı bulardor

5. ovlī qullär oturmuš Ḥäqq șuḥbät eylär

6. gälin görun ovliyāläri bulardor

7. axan ärxlär axan čaylär bulaxlar

8. qäțräh qäțäh qarıšob däryā-1 ${ }^{\circ}$ Ommanı bulardor

9. yavoq gäl iraq getma Quščığlı

10. Tarı xäbärin istärsän tanı bulardor

1. Sehet aufrichtig den Xāvändıgār als die Wahrheit an, weil nur die Wahrheit-Liebenden so beobachten.

2. Er erschuf die Sieben Wesen mit Freude. Die Sieben Wesen lieben alle.

3. Xāvändıgār ist der Gipfel aller Geheimnisse.

4. Diese Sieben Wesen werden von der Wahrheit geliebt, sie sind ebenso das Heilmittel für eure Schmerzen.

5. Adlige Diener (Sieben Wesen) sitzen. Und die Wahrheit spricht sie an.

6. Erkennt, dass sie (die Sieben Wesen) Dīvān (Gerichtshof Gottes) sind.

7. Die fließenden Bäche, die fließenden Flüsse und die Brunnen,

8. Sie sind Tröpfchen für Tröpfchen zusammen gekommen, so wurden sie zum `Oman-See.

9. Komm du näher, entferne dich nicht, Quščıġl1,

10. Wenn du etwas über Gott wissen willst, sollst du sie (die Sieben Wesen) kennen lernen. 


\section{Kälām Nr. 19}

1. āšınānun ümīdi Sulțān Säḥākdor

2. äränlär jüumlähsi `Äršda mäläkdor

3. meydān ičinda čögān čalanlar

4. ollar nūr-1 Yäzdān šīr o pälängdor

5. dīnāri ičinda qälbi olanlar

6. Äränlär noṭqi ollara mähäkdor

7. häẓrät-1 Mīrin zāāt o qüdräti

8. qüdrät äyähsi Sulțān Säḥākdor

9. gonähkārsän sän düš xāk-1 därina

10. qullärın kämtäri Qänbär gäräkdor

1. Sulțān Sähāk ist die Hoffnung für den Freund der Wahrheit.

2. Die Sieben Wesen sind Engel in Gottes Pavillon,

3. Sie sind die Polospieler im Spielfeld,

4. Sie sind das Licht Gottes, sie sind die Löwen und die Leoparden.

5. Die, die Falschmünzer ${ }^{129}$ sind,

6. Werden durch den Prüfstein der Sieben Wesen überprüft (Die Rede der

Sieben Wesen ist der Prüfstein, der die falschen Kälāmāt von den richtigen

Kälāmāt unterscheiden kann).

7. Das Wesen des Mīr und seine Macht ist von Sulțān Säḥāk,

8. Der die absolute Macht ist.

9. Qänbär ${ }^{130}$ ! Du der kleinste Diener, du bist der Sünder,

10. Lege dich auf den Boden vor den Thron des Sulțāns Säḥāk.

${ }^{129}$ „Falschmünzer“ sind die Gedichte, die nicht den 24 Dichtern, die die Kälāmāt-1 torkī gedichtet haben, gehören, sondern den anderen, ,falschen“, Dichtern.

${ }^{130}$ Qänbär ist der Name des Dichters dieses Kälāms. 


\section{Kälām Nr. 20}

1. yārānlär yäyävuz Xāvändıgārdor

2. müškilün hạall eylär kimi ki yārdor

3. yaratdi Gövhärdän yeridän gögi

4. bir qädīm pādıšāh vardor hā vardor

5. Bınyāmīnilän bir qovl qoyubdor

6. yārānlär o qovla ümīdvārdor

7. yārānlär oturmuš Ḥäqq ṣöḥbät eylär

8. müštärīsän ver al yaxši bāzārdor

9. māyadārlär māya üsta qāyım qädīmdor

10. jämālun görmäga čöx intiżārdor

11: hạyāt o mämātı üz ba üz eylär

12. giysin bäqā' xäl ätin beyla İqrārdor

13. göylunda šäkk olan mänzila yetmäz

14. mänzila yetirän yäqīn kirdārdor

15. vä däsidor gäla kirdi üstuna

16. onun jāarčisi Äyvätḥäšārdor

17. Qul Qāsım yaslan yārun xāk-ı̈ärına

18. qädīm Ĵäm du āsi biza tīmārdor

1. Freunde der Wahrheit! Euer Herr ist Sulțān Säḥāk.

2. Er löst die Probleme dessen, der ein Freund der Wahrheit ist.

3. Er erschuf aus der Perle die Erde und den Himmel,

4. Er ist König seit aller Ewigkeit,

5. Er vereinbarte mit Bınyāmīn ein Wort,

6. Freunde der Wahrheit glauben an dieses Wort.

7. Die Freunde der Wahrheit sitzen und die Wahrheit redet.

8. Du Kunde, verkauf und kauf ein! Das ist ein gutes Geschäft ${ }^{131}$.

9. Die Reichen (die ehrlichen Gläubigen) sind aufgrund ihres Kapitals auf ewig unerschütterlich (fest in ihrem Glauben).

10. Wir warten auch leidenschaftlich darauf, dir zu begegnen.

\footnotetext{
${ }^{131}$ Das Wort von Sultāan Sähāàk und das Zuhören der Yārān ist ein Gewinn bringender Handel bzw. eine Erlösung.
} 
11. Er (Sulțān Säḥāk) stellt Leben (die Yārān) und Tod (die Ungläubigen) einander gegenüber:

12. Es wurde von ihm so festgelegt, dass nur die echten Freunde der Wahrheit ewig leben (das „Bäqā’ Xäl ätin-Kleid anziehen).

13. Derjenige, der in seinem Inneren verzweifelt, erreicht sein Haus nicht.

14. Ein reines Ritual bringt den Yār nach Hause.

15. Sein Versprechen ist, dass er zum vereinbarten Termin kommt.

16. Sein Posaune ist Äyvät Häšār ${ }^{132}$.

17. Qul Qāsım ${ }^{133}$, du bist ein Diener, bete!

18. Lege dich auf den Boden vor Yār (Sulțān Säḥāk).

\footnotetext{
${ }^{132}$ Äyvät Ḥäšār ist eine weitere Verkörperung von Bābā Yādıgār und ist mit Esrafil vergleichbar.

${ }^{133}$ Qul Qāsım ist der Name des Dichters des Kälāms.
} 


\section{Kälām Nr. 21}

1. yārānlär äyävüz Xāvändıgārdor

2. näh `äjäb Šärț o Šun hämrāhi vardor

3. Räsūlollāhdor onun yār ọ Häbībi

4. Ämīrälmo'mınīn täk šīi vardor

5. Ḥäqq näżär eylämuš bu üč kimsäya

6. sizun deduqlariz hā bulardor

7. birinin adini Äxī oxullar

8. bir ādinan Bınyāmīn yārdor

9. birinin adini Mūsā oxullar

10. al äla Qälämun di väqt-ı kārdor

11. birinin adini Dāvūd oxullar

12. išlägin nä isa yolunda vardor

13. här kimin varisa älinda näqdī

14. qüdrätdän gälän o tuḥ̂ăh o nārdor

15. yārānlär yārsuz Jännäta varmam

16. Jännätin ārzūsı biza dīdārdor

17. Quščiogi l jarla țālıb ẹšitsun

18. bu gälän dog̀ri o doġri yārdor

1. Freunde der Wahrheit! Euer Herr ist Xāvändıgār.

2. Welch ein wunderbarer Pakt und wunderbare Regeln begleiten ihn!

3. Der Prophet Gottes, Muhammad, ist sein geliebter Freund,

4. Er hat einen Löwen, der `Älī heißt.

5. Xāvändıgār schenkt seine Aufmerksamkeit drei Personen,

6. (euch sind diese drei Personen auch bekannt):

7. Einer von ihnen heißt $\ddot{A} x \overline{1}$,

8. Sein anderer Name ist Yār Bınyāmīn;

9. Der nächste ist Mūsī.

10. Sag ihm: Nimm deine Feder, es ist Zeit zu arbeiten.

11. Einer von ihnen ist Dāvūd.

12. Dāvūd! Mach alles, was zu deinen Aufgaben gehört.

13. Jeder, der seine Aufgabe gut erledigt,

14. Bekommt ein Geschenk vom Mächtigen (Sulțān Säḥāk), 
so wie es einst aus einem Granatapfel ${ }^{134} \mathrm{kam}$.

15. Freunde der Wahrheit! Ich trete nicht ins Paradies ohne Yār,

16. Weil unser Wunsch nach dem Paradies der Wunsch ist, einen Yār zu sehen.

17. Quščioġl1, schrei so laut, dass alle Suchenden hören,

18. Dass der zu uns kommende der echte Freund der Wahrheit ist.

\footnotetext{
${ }^{134}$ Damit ist die Geburt Bābā Yādıgārs aus einem Granatapfelkern gemeint.
} 


\section{Kälām Nr. 22}

1. män billäm jüumlanin gämxōri yārdor

2. yārloq bünyādun qoyan Xāvändıgārdor

3. yārānlär ümīdi sänsän ‘äzīzim

4. Tari tanıyana Tari hā yārdor

5. bī-ädäblär gälmäsın bu Jäm içina

6. bīgümān äglänän bu donda yārdor

7. Pīr Mūsī pīr Dāvūd pīrım Bınyāmīn

8. avçi Šāh İbrāhīm ẹvina därkārdor

9. Quščiog̉lı quldor Qul-Välī gülām

10. kämīna qullarun Budaġda vardor

1. Ich weiß, dass ein Yār mit allen Mitleid hat.

2. Xāvändıāar ist der Gründer der Yārıstān-Gemeinschaft.

3. Mein Liebster, du bist die Hoffnung für alle Freunde der Wahrheit.

4. Wenn jemand Xāvändıgār annimmt, wird Xāvändıgār für ihn ewig ein Yār.

5. Derjenige, der die Yārıstān-Moral nicht berücksichtigt, darf in dieses Jäm nicht eintreten.

6. Nur derjenige, der keinen Zweifel hat, ist in dieser Verkörperung ein Yār.

7. Meine Führer sind Pīr Mūsī, Pīr Dāvūd und Pīr Bınyāmīn.

8. Šāh Ibrāhīms Haus ist für diese drei immer offen.

9. Quščığlı ist ein Diener. Qul-Välī ist ein Knecht.

10. Budā $\dot{\mathrm{g}}^{135}$ ist auch dein kleiner Diener.

\footnotetext{
${ }^{135}$ Budāg ist der Name des Dichters dieses Kälāms.
} 


\section{Kälām Nr. 23}

1. bugün Bäğdād šähri mä mūr olobdor

2. eylä ki Šāh İbrāhīm ämīr olobdor

3. mübāräk qädämin bura basali

4. ävliyālär barçası pornūr olobdor

5. Šāh İbrāhīm hụukmı Bäg̀dād ičinda

6. sälāṭīnlär gälobdor qul olobdor

7. aradan Šäț̣ axar burj o bārähs1

8. särānun ičina xūblar dolobdor

9. bizdän siza qalan bu dogri yoldor

10. āšıkārun deyin mänšūr olobdor

11. gälin ümīdi Häqqa bag̉leyun yārānlär

12. Häqqsiz yeri gördom vīrān olobdor

13. räqīibi gördom azdorob rāhi

14. säna san bir hịimār murdār olobdor

15. bäs sän deyirdun doġri yār mänäm

16. näičun yār yārondan yād olobdor

17. pärästiš itdigim zāat-1 müeäżżäm

18. na doġar na ölur dovrān olobdor

19. Xorāsān ṣäḥrāsında bāj alanlär

20. Bäġdādda gälübdor yäkdil olobdor

21. Quščiog̀lı quldur Dīvāndan gälür

22. yıq1lın dog̣rilär färmān olobdor

1. Heute ist die Stadt Bäğdād zurechtgemacht,

2. Als ob Šāh Ibrāhīm zu ihrem Emir geworden wäre.

3. Seitdem er seine gesegneten Schritte hierher lenkte,

4. Sind alle Staatsmänner voller Hoffnung.

5. Nach dem Befehl von Šāh İbrāhīm,

6. Sind die Könige in Bäġdād angekommen, um seine Diener zu werden.

7. Ein großer Fluss fließt durch die Stadt und ihre prächtigen Festungen. 
8. Die Schlösser ${ }^{136}$ sind voll von Hübschen (Yārān).

9. Der geerbte Weg ist für uns aber der echte Weg (Glauben).

10. Sagt ihr offen, was unser Gebot ist.

11. Kommt! Yārān! Hofft auf die Wahrheit.

12. Ich sah, wie der sündhafte Boden verwüstet wurde.

13. Ich sah, wie der Zweifelnde zum Heimatlosen wurde.

14. Du würdest glauben, dass er ein toter Esel ist.

15. Dein Versprechen war, dass du ein ehrlicher Yār bist.

16. Warum vergaß ein Yār seine Treue?

17. Die Göttlichkeit, die ich anbete,

18. Kommt mir wie das ewige Zeitalter vor.

19. Die gnadenlosen Tributeinnehmer aus den Steppen Xorāsāns

20. Kamen in Bägdād an, um im Herzen gläubig zu werden.

21. Quščığlı ist ein Diener, er kommt aus dem Dīvān.

22. Kommt zusammen, ihr Ehrlichen! Es gibt einen Befehl für euch.

\footnotetext{
${ }^{136}$ Wo Šāh İbrāhīm, der jüngste der Sieben Wesen, lebt, ist ein Paradies. Die Häuser sind „Schlösser“, die Menschen sind hübsch und nobel. Die Yārıstān sind aber tatsächlich meistens arm und elend.
} 


\section{Kälām Nr. 24}

1. tövḥīd ičära mu’minin īmāni bir iqrārdor

2. qābil-1 räḥmät däyor kim müršida inkārdor

3. var gidaq ähl-1 bärātdän ista här mäqșudov1

4. düš ayaqina onun yüz nāmūsilän 'ārdor

5. pīr yoluna varmeyan olmaz murīd o märd-1 rāh

6. o kämär ki baġlıyobdor belina zünnārdor

7. baš o ĵāndan gečmeyän irmäz bu 'išqin rämzina

8. däyma här särsäreya bu bul'äjäb bāzārdor

9. ola bir ähl-1 näżär nādān yanonda da yazlıq

10. Ḥäqq onı gostärmäsin hıč kimsäya dušvārdor

11. här kimin dunyāda bir delxōhı vardor dūstdan

12. zāhidin ārzūsi Jännät 'āšıqın dīdārdor

13. var jähān dušmän olob yüz mäkr eda kār eylähmäz

14. äy Qäländär ona ki fäẓl-1 İlāhī yārdor

1. Der Glaube an Īqrār (an den Pakt von Binyāmīn) ist der Kern des Glaubens.

2. Derjenige, der seinen Führer nicht akzeptiert, darf nicht begnadigt werden.

3. Komm! Lass uns zu den von Gott geliebten Menschen gehen, sie werden deine Wünsche erfüllen.

4. Werfe dich zu ihren Füßen. Dadurch wirst du hundert Mal stolzer.

5. Derjenige, der nicht hinter seinem Führer läuft, wird nicht fromm

6. Und sein Yārān-Gurt, den er umschnallte, ist ketzerisch.

7. Wenn jemand auf seinen Kopf und auf sein Leben nicht verzichtet, kennt er das Geheimnis der Liebe nicht.

8. Erzähle dieses Geheimnis der Liebe nicht allen, weil viele Menschen dieses nicht nachvollziehen können und nur Chaos verursachen würden.

9. Ob ein Wissender mit einem Unwissenden zusammen leben kann?

10. Bitte, Gott! Tue so etwas niemandem an, weil das für niemanden leicht ist.

11. Jeder hat in der Welt einen Geliebten.

12. Der Asket wünscht das Paradies und der Verliebte wünscht die Geliebte zu treffen.

13. Wenn die ganze Welt zum Feind würde und hunderte von Tricks einsetzte, 
würde sie es nicht schaffen,

14. Gegen denjenigen, der von Gott begnadigt ist, zu siegen.

Du, Qäländär ${ }^{137}$, weißt darüber Bescheid.

${ }^{137}$ Qäländär ist der Name des Dichters dieses Kälāms. 


\section{Kälām Nr. 25}

1. yārānlar ẹ̌sidin siz bu Kälāmi

2. Bınyāmīn vä däsi iżhār olobdor

3. Dāvūda nīstlikdän ridā verildı

4. pīr Mūsī qälämin yazar olobdor

5. Äränlärin `ähd o iqrari yetdı

6. aq ‘äläm čixibän pārlar olobdor

7. jähān bäxš olan qädīmī zärra

8. Xōjäm färmānidor iqrār olobdor

9. nīm Rūz qalob o Bäyābästa

10. Pīrdävär atlosi sävār olobdor

11. ruxṣät verildi jümla mämāta

12. bašlarun götörob bīdār olobdor

13. Bınyāmīn šāgirdläri yol gözlasin

14. pādıšāh ämridor Kırdār olobdor

15. Äyväthäšārı jāarin jāârlähdi

16. Xānıdān quluna xäbar olobdor

17. kämtärīn qulundor bu gūyända Häsän

18. jāanundan gečobän nis̄ār olobdor

1. Hört ihr, Yārān, diesem Kälām zu!

2. Das Versprechen von Bınyāmīn ist wahr geworden.

3. Dāvūd bekam aus dem Nichtsein Hilfe ${ }^{138}$.

4. Die Feder von Pīr Mūsī begann zu schreiben.

5. Das Versprechen und das Bekenntnis der Sieben Wesen sind erfüllt worden.

6. Eine weiße Fahne wurde nach draußen gebracht und wehte im Wind.

7. Der ewige Funke schuf die Welt.

8. Das war ein Befehl von meinem Herrn. Dieser ist schon erfüllt.

9. Mittagshelligkeit herrscht in Bäyābäst, weil ein

10. Reiter (Dāvūd) von Pīrdävär auf seinem Pferd sitzt.

11. Alle Verstorbenen bekamen die Erlaubnis,

12. Ihre Köpfe zu erheben und aufzuwachen.

\footnotetext{
${ }^{138}$ Hier ist die Hilfe Gottes.
} 
13. Die Schüler Bınyāmīns passen darauf, dass

14. Der Befehl des Königs erfüllt wird.

15. Äyvät Häšār blies in sein Horn.

16. Dadurch wurde die Xānıdān des Dieners (des Dichters dieses Kälāms) gewarnt.

17. Der Dichter Häsän ist der kleinste Diener,

18. Er verzichtet auf sein Leben und widmet es dem Sulțān. 


\section{Kälām Nr. 26}

1. gäl äy göhär alan kān ävliyādor

2. tükänmäz gänĵ-1 pinhān ävliyādor

3. Häqīqät ählini Ḥäqqdän görma ayri .

4. Häqīqät ‘äyn-1 burhān ävliyādor

5. münävvär eyläyän bil jümla jähāni

6. čırāg o nūr-1 îmān ävliyādor

7. täjällā göstärän o mihr o māha

8. fäläk burĵnda tābān ävliyādor

9. oyan ġıflätdän äy miskīn oyaq ol

10. sänün därdiva därmān ävliyādor

11. Mohämmäd Müșțäfānun eäyn-1 zāātı

12. ki sirr-1 Šāh-1 märdān ävliyādor

13. Qäländär sän qul ol ävliyāya

14. jämīe eàlämda sulțān ävliyādor

1. Komm, du Perlenkäufer, deine Quelle sind die Heiligen ${ }^{139}$.

2. Die Heiligen sind ein verborgener, unendlicher Schatz.

3. Siehe die Freunde der Wahrheit nicht getrennt von der Wahrheit an.

4. Die Heiligen sind dasselbe, wie die Wahrheit.

5. Die Welt ist durch die Heiligen beleuchtet,

6. Die das Licht und die Strahlung des Glaubens sind.

7. Die Heiligen machen die Sonne und den Mond herrlich strahlend.

8. Die Heiligen sind das strahlende Sternbild des Universums.

9. Wach auf, du Elender, du Nachlässiger, sei wach!

10. Die Heiligen sind das Heilmittel für deine Schmerzen.

11. Der Inbegriff des Existierens ist Muhammad der Prophet,

12. Die Heiligen sind das Geheimnis von Šāh-ı Märdān ${ }^{140}$ (e

13. Du Qäländär! Sei ein Diener für die Heiligen,

14. Weil sie in der ganzen Welt die Herrscher sind.

\footnotetext{
${ }^{139}$ Die Heiligen (ävliyā') sind die Yārıstān, die einen Funken von Sulțān Säḥāk besitzen.

140 Šāh-1 Märdān heißt wörtlich „König der Männer“ und bezieht sich auf `Älī den Imam.
} 


\section{Kälām Nr. 27}

1. Äränlär mänzili jāan mänzildor

2. jāan vermäga Šāh-1 xūbān mänzilidor

3. verän o kimsänädor kim ola täslīm

4. İsmāê̄l qurbāni jāan mänzilidor

5. čoxlar deyär bašım yārin yolunda fädādor

6. geča bilmäz ki insān mänzilidor

7. başın top eyläya qoluni čögān

8. süst durma ki märd-1 mäydān mänzilidor

9. gögdän gäl Kälāmollāhi gör ki

10. oxuyanlar bilür kān mänzilidor

11. qapudan bād-1 säḥär ötmamiškän

12. `1brät q11 ki Süläymān mänzilidor

13. Qāsım yaslan yārin xāk-1 därina

14. här șäbāḥ Yārin güzärgāḥ mänzilidor

1. Das Haus ${ }^{141}$ der Sieben Wesen ist das beliebteste Haus.

2. Dieses Haus ist gut, um sich zu opfern, weil der König der Besten dort wohnt.

3. Derjenige, der sich aufopfern will, passt sich diesem Haus an.

4. Ismāê̄ls Opferbereitschaft ist das Haus des Lebens.

5. Viele behaupten, dass sie ihre Köpfe auf dem Wege des Glaubens opfern.

6. Sie tun dieses aber nicht, weil sie Menschen sind (weil das nicht für alle machbar ist).

7. (Du, Yār), mach aus deinem Kopf einen Ball und aus deinem Arm einen

Stab für das Polospiel.

8. Sei zielstrebig, weil dieses Haus ein Haus für die Kühnheit ist.

9. Sieh dir das aus dem Himmel gekommene Wort Gottes an, das

10. Die Leser kennen: Das Wort ist eine Quelle für Perlen.

11. Solange die Morgenbriese vor der Tür weht,

12. Nutze es, weil es das Haus Salomons ist.

13. Du, Qāsım, wirf dich auf den Boden vor der Tür des Yār,

14. Weil der Yār jeden Morgen dort vorbei läuft.

\footnotetext{
${ }^{141}$ Hier wird die Welt gemeint.
} 


\section{Kälām Nr. 28}

1. jähān bašdan baša var därd-1 särdor

2. gečän bu därd-1 särdän gärčäg ärdor

3. dedim čūn Müșțäfã dunyā-1 fān̄̄

4. bu rämzi fähm edän ähl-1 näżärdor

5. ögüt verräm näṣịhät almaz äy j̄ān

6. hänūz o münkirun qälbi hääärdor

7. ägär Nūḥ-1 näbäbī täk min yašasan

8. nä ḥāṣ̂l dunyādan āxir säfärdor

9. vojūù-1 nāq1ṣa yetma Qäländär

10. näfäs xärĵ eyläma dürr o gövhärdor

1. Die Welt bereitet, seitdem sie existiert, nur Kopfschmerz (Sorge).

2. Wenn jemand diese Sorge vermeiden kann, ist er ein großartiger Herr.

3. Ich sagte, wenn jemand das Geheimnis dieser vergänglichen Welt wie Muhammad der Prophet

4. Versteht, dann ist er ein Mann Gottes.

5. Ich gebe einen Rat, aber er wird nicht akzeptiert

6. Vom Abtrünnigen, dessen Herz immer noch aus Stein ist.

7. Auch wenn du wie der Prophet Noah tausend Jahre lebst,

8. Macht es keine Unterschiede, denn letztendlich wirst du verreisen (sterben).

9. Du, Qäländär, verstehe, dass du dich um die mangelhafte Menschenexistenz nicht mehr kümmern musst.

10. Gebrauche deinen Atem nicht zu viel, weil du umsonst deine Perlen und Rubine verbrauchst. 


\section{Kälām Nr. 29}

1. Äränlär Häqqina häyrān šäb o rūz āhi budor

2. Häqqdän özga bilmäm sụ̂1 günāhi budor

3. kim ki yol qulıyam deyir Ḥäqq desun İbrāhīma

4. Ḥäqq dāīvānın o bašarur šāhlarun šāhı budor

5. yetmiš ikki dil ičinda Gūrānja söylärdi

6. `Ärš o Kürsī yaradan `ālämin Āllāhi budor

7. bir `āšıq däftärin ačmuš Räzzāqın sırrın oxur

8. kim ki bü sözi anlamaz zāhidin gümrāhi budor

9. äränlär övliyālär jümlasi Ḥäqqdor nāḥäqq deyur

10. dug̣rusın män deyiräm xäbärin sāhī budor

11. äränlär bir yol qoymuš dost dog̉ri Ḥäqqa gıdär

12. kim ki Häqqa dog̉ri gıda gälun dog̉ri rāhı budor

13. Quščıġlı deyir Ḥäqq1 `āläm āškāra görmušäm

14. bäyānun Bınyāmīn verär gälun ki gävāhi budor

1. Es ist recht, sich Tag und Nacht nach den Sieben Wesen zu sehnen.

2. Es gibt nur eine Sünde: sich von der Wahrheit entfremdet zu verhalten.

3. Derjenige, der behauptet, dass er ein Diener der Wahrheit ist, muss Šāh İbrāhīm als die Wahrheit anerkennen.

4. Er kennt den Dīvān, weil er der König der Könige ist.

5. Seine Ansprache war in Gūrān̄i, einer der 72 Sprachen der Welt.

6. Derjenige, der den Sitz und Thron Gottes in der Welt schuf, ist unser Gott.

7. Ein echter Yār öffnet ein eigenes Heft ${ }^{142}$ (blickt ins eigene Herz), um das Geheimnis des Nahrungsspenders (Gottes) zu entdecken.

8. Wenn jemand dieses nicht versteht, ist er ein verderbter Asket (Mullāh oder islamischer Sufi).

9. Die Sieben Wesen und die Heiligen sind echt, sie sind keine falschen.

10. Ich sage die Wahrheit. Was ich berichte, ist richtig.

11. Der Weg, der von den Sieben Wesen errichtet wurde, ist der Weg zur Wahrheit.

12. Ihr, die die Richtung der Wahrheit gehen wollt, kommt her,

\footnotetext{
${ }^{142}$ Mit dem „Heft“ bezeichnet man im Persischen eine Sammlung der Liebesgedichte eines der größten Dichter wie Hafiz, Sä'dī, Movlävi.
} 
der richtige Weg ist da.

13. Quščığlı sagt, dass er die Wahrheit offen und klar sah.

14. Bınyāmīn drückt diesen Weg aus. Kommt her, die Aussage Bınyāmīns ist da. 


\section{Kälām Nr. 30}

1. Äränlär ävliyā'lär Ḥäqq ẹvina jāāa gälübdor

2. yārānlär bu yola šikästa o üftāda gälübdor

3. kimsa kimsaya güĵ eylämäsün gäl yār ol

4. yārlıq ẹvina `ıšq1la irāda gälübdor

5. yüzmin ḥâ̄̂̄iär dävä minub Häâĵa varallar

6. bizim ḥâj̄̄lärimiz Ḥäqq ẹvina piyāda gälübdor

7. mäsĵida girub dīvāra süĵda q1lanar

8. dīvāra süĵ̉da q1lmaq yāda gälübdor

9. Quščığlı Bäg̉dādı qoyub Mäkkäya varma

10. Mäkka yerindän qopub Bäğdāda gälübdor

1. Die Sieben Wesen und die Heiligen sind zum Haus der Wahrheit (Gotteshaus) auf einem richtigen Weg strebend angekommen.

2. Die Freunde der Wahrheit sind bescheiden und zurückhaltend zu diesem Weg gekommen.

3. Niemand darf einen anderen zwingen und sagen: komm, werde ein Freund (der Wahrheit)!

4. In die Behausung der Freundschaft soll man mit Liebe und eigenem Willen kommen.

5. Hunderttausende von Hädschis müssen auf Kamelen weit reiten, um Mekka zu besuchen.

6. Unsere Hädschis (die Yārān) sind zu Fuß ins Haus der Wahrheit gekommen.

7. Man geht in die Moschee, um die Wand anzubeten.

8. Das Wandgebet wird immer wieder ins Gedächtnis gerufen.

9. Du Quščığlı, verlass Bäğdād nicht, begib dich nicht nach Mekka!

10. Mekka ist vom Platz aufgesprungen und ist nach Bäğdād ${ }^{143}$ angekommen.

\footnotetext{
${ }^{143}$ Säyyed Kāzem Nīknežād kommentiert dieses Kälām so, dass Bagdad eine wichtigere Stadt als Mekka ist, weil sie die Residenz von Šāh İbrāhīm ist.
} 


\section{Kälām Nr. 31}

1. hävāra tız yetän sävārimiz var

2. Ḥäqqi täḥqīq eylämišuq hạqq yārimiz var

3. bizi bīkäs bilub qäṣda gälullär

4. mäğrıbdän mäšrıqa hävārimiz var

5. dort țäräfdän üstümüza näqīm sürällär

6. här țäräfdän gälsälär hā čāramiz var

7. siza āsān gälür kärpüč qäl`alär

8. fūlāddan pärčīndän häạsārımız var

9. min sarudan biza â̂ deyällär

10. bizim bir tukänmäz änbārımız var

11. bu yola gälursän ädäbilän gäl

12. bī-ädäb gäläna mismārımız var

13. nä bākim var hizārān Mänčäridän

14. ki xān Äḥmäd kimin särdārımız var

15. doqsan min kälima q1ldı Muhämmäd

16. ottoz minindän xäbärimiz var

17. Quščıg̀lı quršan Häqqä bāqīidor

18. amāndor xōjäm günähkār särimiz var

1. Wir haben einen Reiter (Dāvūd), der uns unverzüglich hilft.

2. Wir haben die Wahrheit nachvollzogen und wissen, dass wir einen wahren Helfer haben.

3. Die Gegner meinen, dass wir einsam und hilflos sind,

4. Aber wir haben Helfer vom Westen bis zum Osten.

5. Die Gegner graben von vier Seiten eine Sappe aus (um uns zu erobern).

6. Jedoch haben wir von allen Seiten die Möglichkeit (uns zu verteidigen).

7. Ihr meint, dass eine Festung aus Rohziegel leicht zu erobern ist.

8. Unsere Festungen sind aus Stahl.

9. Aus tausend Gründen halten uns die Gegner für Verhungerte.

10. Wir haben aber endlose Reserven.

11. Wenn du zu unserem Weg kommen willst, beachte dann unsere Prinzipien. 
12. Für diejenigen, die unsere Prinzipien nicht beachten, haben wir einen Hakennagel.

13. Ich fürchte mich vor Tausenden von Mandschuren nicht,

14. Weil wir einen Armeeführer wie Xān Äḥmäd haben.

15. Muhammad der Prophet flüsterte neunzigtausend Wörter.

16. Davon kennen wir dreißigtausend.

17. Quščığl1, der die Wahrheit bestätigt, bleibt dabei.

18. Begnadige uns, mein Herr! Wir haben sündige Köpfe. 


\section{Kälām Nr. 32}

1. Ibrāhīm șūr bizim sulțānımızdor

2. żāhirda bāṭında särdārımızdor

3. yeddi yerda onun ḥukmi yeridi

4. yeddi gögda mövjūd Ällāhomızdor

5. ḥukum išāräti üstuma gäldi

6. ġıflätdän oyadan bīdārımızdor

7. jäfă čäkdoq xūnāb yedoq bu yolda

8. biza öldi demäyün seyrānımızdor

9. xälāyiqlär biza häqīr baxallär

10. danna Mäḥšär güni dīvānımızdor

11. biz Iqrār ähliyuq inkārımız yox

12. Ḥäqīqät näfäsi guftārımızdor

13. pādıšāhın nuṭq1 šäfādor biza

14. jäämdän täkbīr alun tīmārımızdor

15. Äränlär yol verällär yol alullär

16. qädīmdän qalan ärkānımızdor

17. Quščığlı müjärräd hayandador

18. bāṣıfät bīnišān o pīrimizdor

1. Ibrāhīm Șūr ${ }^{144}$ ist unser König.

2. Er ist sowohl nach außen als auch nach innen unser Armeeführer.

3. Sein Befehl gilt in den sieben Erden ${ }^{145}$.

4. In den sieben Himmeln ist unser Gott anwesend.

5. Der Befehl Ibrāhīms erreichte mich.

6. Die Wachsamkeit weckt uns aus der Nachlässigkeit.

7. Wir haben uns gequält, wir haben auf diesem Wege (des Lebens in der Yārıstān-Gemeinde) unser Blut geschluckt.

8. Nennt ihr uns nicht gestorben! Es ist eine Umgestaltung.

9. Andere Geschöpfe (Völker, Religionen) verachten uns.

\footnotetext{
${ }^{144}$ Ibrāhīm Șūr (der rote Ibrāhīm) ist ein Spitzname von Šāh Ibrāhīm, den er wegen seines roten Gesichtes bekommen hat.

${ }^{145}$ Mit „,sieben Erden“ werden nach altiranischer metaphysischer Weltanschauung die sieben irdischen Ebenen im Unterschied zu den sieben himmlischen Ebenen bezeichnet. Man sieht diese „,sieben Erden“ auch bei den Yeziden (vgl. Kreyenbroek 1995).
} 
10. Erzähle ihnen, dass Gottes Endgericht unser Divān (Gerichtshof Gottes) ist.

11. Wir sind die Freunde des Paktes, wir sind keine Ungläubigen.

12. Der Atem der Wahrheit ist unsere Rede.

13. Die Rede unseres Königs ist ein Heilmittel für uns.

14. Im Jäm zu flehen ist eine Verpflichtung für uns.

15. Die Sieben Wesen zeigen den Weg und verlangen nach dem Weg ${ }^{146}$.

16. Dieses ist seit aller Ewigkeit unser Fundament.

17. Du Quščıg̀ilı, wo ist Sultān Sähāk?

18. Er hat Eigenschaften, hat aber keine äußeren Kennzeichen. Er ist unser Pīr.

\footnotetext{
${ }^{146}$ Mit ,zeigen den Weg und verlangen nach dem Weg“ bezeichnet der Dichter die Kälāmāt-Sprache. Die Yārān greifen nach Begriffe der Yārıstān-Lehre oder nach Ausdrücken der Kälāmāt in ihrer Alltagssprache.
} 


\section{Kälām Nr. 33}

1. jähān bašdan baša yār olaĵaqdor

2. ačoluban gül gülistān olaĵaqdor

3. Tari kärämilän q1lar lüțfini

4. murda ĵismlära jāan olajaqdor

5. čähār iqlīmda olar bir ovlī savaš

6. gävädalär aparan qan olajaqdor

7. sulțānlar qırqını Sulțāniyada

8. Zänjāanda bir ovlī dīvān olaĵaqdor

9. yeddi gün yeddi geĵa at sürällär

10. Mäḥ̌šär qoyuban țūfān olaĵaqdor

11. Äränlär yıqılur gälür bir yera

12. bu söz yalan deyür eäyān olajaqdor

13. yetmiš ikkidän sečilür gurūh-1 nāĵ̄

14. olaričun bir ovlī šä'n olajaqdor

15. `Älī nä 'ra vurar čıxar jähāna

16. jähān ḥukmunda färmān olaĵaqdor

17. Quščıog̉ınun ümīdi yegāna qullar

18. olarun xäl äti bāqī jāâvdān olajaqudor

1. Die Welt wird überall voller Freunde (Yārān) sein (an dem Tag, an dem Sulțān Sähāk erscheint).

2. Die Welt wird überall zum blühenden Blumengarten werden.

3. Gott wird sich mit seiner Großmut und Liebe an die Menschen wenden.

4. Er wird den gestorbenen Körpern das Leben geben.

5. Ein entscheidender Krieg wird in allen vier Weltteilen stattfinden.

6. Es wird so viel Blut vergossen, dass seine Flut die Leichen mitnehmen wird.

7. In der Stadt Sulțāniya werden unsittliche Könige verurteilt,

8. Und ein hoher Dīvān wird über sie in der Stadt Zänjāan abgehalten.

9. Die Reiter (Sieben Wesen) werden sieben Tage und sieben Nächte reiten.

10. Am Tag des jüngsten Gerichts wird ein Sturm toben.

11. Die Sieben Wesen kommen zusammen auf einem ausgewählten Platz. 
12. Das ist keine Lüge, es wird alles sichtbar werden.

13. Es wird aus den 72 Pīrān eine Rettungsgruppe gewählt.

14. Es wird für sie eine Ehre sein.

15. 'Älī ruft laut und tritt in der Welt auf.

16. Die ganze Welt steht unter seinem Befehl.

17. Quščıg

18. Deren Ehrenkleider (die Körper) ewig blieben werden. 


\section{Kälām Nr. 34}

1. jähān bašdan baša yār olaĵaqdor

2. münkir olan xōr o zār olajaqdor

3. Bınyāmīn šärținda gaämmāz olanlar

4. häyvānṣıfät bir ḥimār olajaqudor

5. nārızāa tikka jāān āzārasidor

6. danla ki gün irin qan olaĵaqdor

7. Äyvät čıxıbän mäšrıqda jārlar

8. mäğrıbda yār olan xäbar olajaqudor

9. Pīrdävärdän čixar bir täk atlo

10. jähān tözdan pürg̉ubār olậaqdor

11. Ḥäqīqät ählina inkār olanlar

12. olarun yerläri nār olajaaqdor

13. här yār deyän yār ola bilmäz Quščıg̀̉

14. šärāb-1 lāfičin xōr olajaqdor

1. Die Welt wird überall voller Freunde (Yārān) sein (an dem Tag, an dem Sulțān Sähāak erscheint).

2. Die Abtrünnigen werden elend und des Jammers voll.

3. Die, den Pakt Bınyāmīns verleumden,

4. Werden zu Eseln und bekommen tierische Eigenschaften.

5. Wenn jemand von den Anderen gegen seinen Willen gefüttert wird, verursacht das Essen eine Erkrankung.

6. Erzähle demjenigen, der solches Essen annimmt, dass es am Tag des jüngsten Gerichts zu einem Blutklumpen wird.

7. Äyvät ${ }^{147}$ kommt aus dem Osten, um seine Posaune zu blasen.

8. Alle Yārān, die im Westen sind, hören ihn.

9. Ein beispielloser Reiter (Dāvūd) kommt von Pīrdävär her,

10. Und die Welt wird voller Staubwolken sein.

11. Die Leute, die die Wahrheit ablehnen,

12. Werden im Feuer sein.

13. Du, Quščioġl1, weißt Bescheid, dass nicht jeder, der sich zu den Freunden

\footnotetext{
${ }^{147}$ Äyvät ist ein anderer Name für Yādıgār.
} 
der Wahrheit rechnet, wirklich ein solcher ist.

14. So jemand wird wegen seiner Prahlerei elend und verachtet werden. 


\section{Kälām Nr. 36}

1. Ibrāhīm ṣūr bizim sulțānımızdor

2. żāhirda bāținda īmānımızdor

3. `ālämlär gıdobän bizda gıdähroq

4. biza öldi demäyün seyrānımızdor

5. jümla xälāyıq aldı mūčasin

6. Šāh İbrāhīm bizim gämxōrımızdor

7. yār yolunda gičdoq kull-1 vardan

8. yār jämāali bizim riẓvānımızdor

9. Quščığlı duš İbrāhīm därına

10. İbrāhīm āstānasi mäydānımızdor

1. Ibrāhīm șūr ist unser König.

2. Er ist sowohl nach außen als auch nach innen unser Glauben.

3. Welten sind vergangen. Wir werden auch vergehen.

4. Nennt ihr uns nicht „Gestorbene“! Es ist eine Umgestaltung für uns.

5. Alle Geschöpfe erhielten ihre Anteile.

6. Šāh İbrāhīm ist unser Mitleidender.

7. Wir verzichten auf alles wegen der Yārıstān.

8. Unser Paradies ist die Schönheit des Yār.

9. Du, Quščığlı, wirf dich auf den Boden vor der Tür İbrāhīms.

10. An der Schwelle der Tür İbrāhīms liegt unser Schlachtfeld. 


\section{Kälām Nr. 39}

1. İlāhī yedigim niemät sänundor

2. müšärräf yaratdun ümmät sänundor

3. günähkār bändayäm bäxšända sänsän

4. käräm kāni sänsän mürvät sänundor

5. sälāṭīnlär sänun xäšmöva dözmaz

6. yer o gög titräšür heybät sänundor

7. uĵa daġlara ägil desän ägilir

8. ägilir yixilmäz țāqät sänundor

9. yer üzün bäzadun dürrlo čičäkdän

10. münja äšyā’ verilän ḥikmät sänundor

11. onsäkkizmin 'āläm sirrunda peydā

12. yetmišikki dilda söylänän țāeät sänundor

13. nä yatubsän dur ey Quščınun og̀l1

14. lālkän söylänän dovlät sänundor

1. Oh, Gott! Was ich esse, ist eine Wohltat von dir.

2. Die Schöpfung einer würdigen Nation (Yārıstān) gehört dir.

3. Ich bin ein Sünder und du bist der Barmherzige.

4. Du bist gewiss die Quelle der Großmut. Die Großmütigkeit ist von dir.

5. Die Könige können deinen Zorn nicht ertragen.

6. Die Erde und der Himmel erschrecken sich. Diese erschreckende Macht gehört dir.

7. Wenn du den hohen Gebirgen sich zu beugen befiehlst, beugen sie sich.

8. Sie beugen sich, sie fallen aber nicht um. Diese Widerstandskraft ist von dir.

9. Das Gesicht der Erde schmücktest du mit Blumen wie mit Perlen.

10. Eine so wunderbare Tat kommt nur von deiner Weisheit.

11. Was von deinem Geheimnis zu sehen ist, sind die achtzehntausend Universen.

12. Man betet dich in 72 Sprachen an.

13. Wach auf, du Quščığlı! Wie kannst du schlafen?

14. Obwohl du ein Taubstummer ${ }^{148}$ warst, hast du jetzt das Glück, zu sprechen.

${ }^{148}$ Diese Passage spielt auf die Heilung Quščıg̉ı̉ıs bei Šāh Ibrāhīm in Bäğdād ein. Mehr dazu siehe im Kapitel II.1.1. 


\section{Kälām Nr. 40}

1. iqrār ähli bizim iqrārımızdor

2. yäqīn o iqrār o ixlāṣ imānımızdor

3. biz iqrār ähleyoq inkārımız yox

4. danla Mäḥ̌är güni hävārımızdor

5. täḥqīq eylämišuq yäqīn bilirox

6. `äzīz Xāvändıgār gämxōrımızdor

7. bu yola varirsan doġrilikilän

8. Äränlär mänzilı gülz̄ārımızdor

9. gärčäg olanlar versünlr Bära

10. silsila bag̉liyün ḥäṣārımızdor

11. sändaki guftārdan kırdār istärlär

12. pādıšāhin nuṭq1 kirdārımızdor

13. pādıšāhin nuṭq1 šäfādor biza

14. jämdän täkbīr alün tīmārımızdor

15. pīrım Bınyāmīn rähbärım Dāvūd

16. qälämzän pīr Mūsī däftärdārımızdor

17. Quščıoglı sändän yemiš istärlär

18. här yemiš istäsalär di varımızdor

1. Wir sind Pakt-Angehörige und bestätigen es.

2. Die Gewissheit, der Pakt und die Aufrichtigkeit sind unser Glaube.

3. Wir sind Pakt-Angehörige und verneinen es nicht.

4. Bestätige, dass das jüngste Gericht unsere Unterstützung ist.

5. Wir prüften es nach, und sind sicher,

6. Dass der liebste Xāvändıgār unser Mitleidender ist.

7. Wenn du zu diesem Weg (dem Glauben) kommst, komm mit Ehrlichkeit.

8. Die Behausung der Sieben Wesen ist unser Blumengarten.

9. Die ehrlichen Yārān sollen Opfer bringen.

10. Dieses Opferritual ist unsere Festung aus geknoteter Kette.

11. Dein Versprechen setzt eine Tat voraus.

12. Die Rede des Königs ist unser Ritual.

13. Die Rede des Königs ist unser Heilmittel. 
14. Im Jäm zu flehen, ist unsere Verpflichtung.

15. Mein Pīr ist Bınyāmīn, mein Anführer ist Dāvūd,

16. Der Schriftführer Pīr Mūsīi ist auch unser Buchführer.

15. Du, Quščıog̀l1, die Yārān verlangen von dir Nahrung (Kälāmāt sind Nahrung für den Glauben),

16. Was an Nahrung verlangt wird, haben wir. 


\section{Kälām Nr. 42}

1. Šāh-1 jähān näżär qilsa quläm zārīla āhim var

2. yüz tutub därgāha varsam yer göyjäk günāhom var

3. tanidum sän Xodāvändı do 'Âlämda bīgäm oldum

4. gän̄iyäm gämgīn deyüram sän ĵylada pänāhom var

5. Sulțān kärämlo bägımdor 'ālämı yāra bäxš itdi

6. biz ümīd ähleyuq bıllā Xōjämdän bu țämä om var

7. Xōjasindän döna bilmäz sıkkalı damqalı qullar

8. Xānıdān quleyam bıllāh čändīn hızār govāhom var

9. Quščıg̉lı nā-ümīd olma ümīdovı Häqqa bag̉la

10. minin bir qovla bag்ušlar Xōjämda bäyla räḥm var

1. Du König der Welt, schenke uns deine Aufmerksamkeit. Ich bin ein Diener, ich jammere und seufze.

2. Wenn ich mich in die Richtung deines Throns wende, dann finde ich meine Sünden so groß wie Erde und Himmel.

3. Seitdem ich dich als Gott kenne, bin ich in beiden Welten ohne Sorge.

4. Ich bin reich, ich bin nicht traurig, weil ich einen Beschützer wie dich habe.

5. Der König ist so großherzig, dass er die Welt dem Yār verschenkte.

6. Wir sind die Hoffnungsangehörigen. Ich schwöre bei Gott, dass ich von meinem

Herrn die Erwartung habe, dass meine Hoffnung immer erfüllt wird.

7. Die schnurrbärtigen Diener (die echten Yārān) können ihren Herren nicht verlassen.

8. Ich bin ein Xānıdān-Diener. Ich schwöre bei Gott, dass ich dafür tausende von Zeugen habe.

9. Du, Quščıg̀il, gib deine Hoffnung nicht auf. Bleibe immer hoffnungsvoll hinsichtlicht der Wahrheit.

10. Die Wahrheit verzeiht tausende Sünden für ein richtiges Wort. So gnädig ist mein Herr. 


\section{Kälām Nr. 43}

1. här kimin väfāl1 yārı yoxdor

2. ägär yüz varısa hıč varı yoxdor

3. rukäš kimsänalär ḥäyvānṣıfät gäzär jähānda

4. onun goftārı var kırdārı yoxdor

5. țūṭīlän kärkäs hämnıšīn olmaz

6. bülbülilän zāgin bāzārı yoxdor

7. bir älda ikkı qarpuz tutmaq olmaz

8. kimin ki ``šqq1 vardor `ārı yoxdor

9. dunyā bāğunda qizilgül xārsiz olmaz

10. o neĵa qizilgüldor ki xāri yoxdor

11. neĵa olom yādlärinän meyxānählärda

12. käsilsin o aqaĵ ki bārı yoxdor

13. Qulog̉lı yārin āzārı yoxdor

14. ägär āzārı varsa bīzārı yoxdor

1. Wer keinen treuen Yār hat,

2. Aber Hunderte von kostbaren Dingen besitzt, hat gar nichts.

3. Lügner, die behaupten, dass sie ehrlich sind, gibt es auf der Welt überall.

4. Diese Lügner sprechen viel, machen aber nichts.

5. Ein Papagei kann nicht mit einem Geier zusammen leben.

6. Die Krähe handelt nie mit der Nachtigall.

7. Mit einer Hand gelingt es nicht, zwei Wassermelonen gleichzeitig zu greifen.

8. Derjenige, der verliebt ist, muss sich nicht schämen.

9. Im Garten der Welt gibt es keine dornlose Rose.

10. Was für eine Rose ist es, die keine Dornen hat?

11. Wie kann ich ohne ihn (ohne den Yār), nur mit den Erinnerungen an ihn, (sogar) in das Schankhaus gehen?

12. Der Baum sei abgesägt, der keine Frucht hat.

13. Qulog̀ $11^{149}$ ! Ein Yār beleidigt niemanden, 14. Und wenn schon, dann ohne Abscheu.

\footnotetext{
${ }^{149}$ Der Name des Dichters dieses Kälāms.
} 


\section{Kälām Nr. 44}

1. här üzüma baxan deyir rängovün zärdası var

2. dedım äy nāšī xälāyıq gözövün pärdası var

3. Häqq jä̈mālin o görär āyenäsı pāk ola

4. qaranqoluq onador ki güzgisinün pası var

5. häâĵ̣ yolunda čiqurušlar ḥâẫīlar äy qāẓīlar

6. yalquz bu yola varmäyün čölı var bārgāsı var

7. yārānlär ümīdvārdor Ḥäqīqät rämzına

8. xälāyeq payun almušlar bu ulušda nāsī var

9. äy fäqīh yüz münājât eyläsän Ḥäqq därgāhına

10. ḥājätun qäbūl däyür čūn göylovün väsvāsı var

11. bir däryāda min gämi görsän äẹäb däyür

12. gämi var gūšasinda ṣädhizār däryāsı var

13. dedilär Quščığluna bīkäsdor kimsası yox

14. neĵa bīkäsdor ki `älī kimin käsı var

1. Jeder, der mein Gesicht anschaut, sagt, dass mein Gesicht gelb ist (dass ich sündig bin).

2. Ich sage: ihr ahnungslosen Menschen! Eure Augen sehen falsch.

3. Derjenige, dessen Spiegel (Herz) sauber ist, sieht die Schönheit der Wahrheit.

4. Derjenige, dessen Spiegel staubig ist, sieht nur das Dunkle.

5. Die Hädschis (die Pilger) und Kadi (die islamischen Richter) machen Lärm und Krach unterwegs nach Mekka.

6. Macht euch nicht allein auf den Weg, weil dieser Weg durch die wilden Steppen und schrecklichen Wüsten führt.

7. Die Freunde der Wahrheit hoffen auf das Wahrheitsgeheimnis.

8. Alle Geschöpfe haben ihre Anteile erhalten; jeder Anteil enthält sein Skelett.

9. Du, islamischer Rechtsgelehrter, wenn du hundert Mal vor die Wahrheit anflehest,

10. Wird dein Flehen nicht erfüllt, weil es in deinem Innern keine Reinheit gibt.

11. Wenn es tausende Schiffe im Meer zu sehen gibt, ist es nicht verwunderlich.

12. Es gibt ein Schiff, in dessen Ecke einer sitzt, der hunderttausend Ozeane hat ${ }^{150}$.

\footnotetext{
${ }^{150}$ Diese Zeile weist auf die bei den Yārān beliebte Geschichte von Gelīm va Kūl (einem anderen Körper von Bınyāmīn) hin (siehe auch im Kapitel II.1.2. nach).
} 
13. Man sagt, dass Quščıġlı einsam ist und niemand bei ihm lebt.

14. Wie kann er einsam sein, wenn `Älī sein Freund ist. 


\section{Kälām Nr. 45}

1. män bir leyl-1 sättārıdom mänı nähāra čäkdilär

2. sildilär güzgümün pasın aydin dīdāra čäkdilär

3. baġladılar bağlanmadom saxladılar saxlanmadom

4. qizmiš äsramiš när kimin mänı qäțāra čäkdilär

5. bir zämān Äxī yārdan ayri dīvāna gäzärdom

6. girdim Näsīmī donuna pūstumı pāra čäkdilär

7. bir müddätda säyyed olub vardom Häläb o Šāma sarı

8. onda da Mänșūrodom Bäğdādda dāra čäkdilär

9. Ḥäqqimlän män biridim qändīl ičinda sirridim

10. qālib mäna bähānador nūridim ḥäjāa čäkdilär

11. o zämānda Muhäämmädin hämdämı `älī yāridi

12. bu zämānda män ĵilada hizār pāra čäkdilär

13. Moḥämmädın gäldiginı min il qabaq biliridim

14. `Älī da xūd Āllāhumuš mänı eÄlī yāra čäkdilär

15. o zämāndan bu zämāna dondan dona gälmišux

16. dedylär gäl xäbar vır mänı xäbara čäkdilär

17. gör kāfärlär `āṣịlär āxır mäna nä etdilär

18. här qāliba qondum košdum mäni häqāra čäkdilär

19. Pādıšāhim o donda șāf Gūrānī söylädım

20. indı bu dona gälählı turkī guftāra čäkdilär

21. Qušč1 Yäēūbun og̉liyam säyyed İbrāhīm quleyam

22. Äränlärin ĵānquseyam män qulı jāara čäkdilär

1. Ich war eine bedeckende Nacht. Sie (die Heiden und Gegner Gottes) zogen mich zum hellen Tag (die Wahrheit zu verraten).

2. Sie reinigten den Grünspan (den Rost) von meinem Spiegel. Sie boten mich den Zuschauern als Sehenswürdigkeit an.

3. Sie banden mich an, ich ließ mich nicht anbinden. Sie hielten mich auf, ich ließ mich nicht aufhalten.

4. Sie brachten mich wie ein von eigener Kraft berauschtes (brunftiges) männliches Leitkamel in die Karawane.

5. Irgendwann wanderte ich wahnsinnig und ziellos weit weg, 
weil Yār Äxī nicht bei mir war.

6. Ich trat in den Körper von Näsīmīi ${ }^{-151}$ ein. Sie (die Heiden und Gegner Gottes) zerrissen meine Haut.

7. Eine Weile wurde ich zu Säyyed und lief in Richtung Häläb ${ }^{152}$ und Šām ${ }^{153}$,

8. Da war ich zu Mänșūr umgewandelt. Sie (die Heiden und Gegner Gottes) hingen mich in Bäğdād auf.

9. Ich war mit meiner Wahrheit vereint. Ich war das Geheimnis im Licht.

10. Die Gussform (der Körper) ist für mich der Vorwand. Ich war die Beleuchtung. Sie (die Heiden und Gegner Gottes) zwangen mich, mich als Stein darzustellen.

11. Damals war ' $̈$ Älī, der Freund der Wahrheit, ein Freund von Muhammad.

12. Zu dieser Zeit war ich in tausende Stücke zerrissen.

13. Ich wusste schon vor tausend Jahren, dass Muhammad kommt.

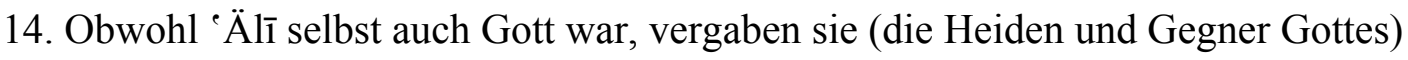
mir nicht und folterten mich, weil ich `Älī als Gott anerkannte.

15. Seit damals bis heute wandeln wir von Körper zu Körper.

16. Sie (die Heiden und Gegner Gottes) zwangen mich, zu berichten.

17. Schau mal! Was taten die Heiden und Gegner Gottes letztendlich mit mir.

18. Ich zeigte mich in den verschiedenen Gussformen (Körpern), trotzdem erniedrigten und quälten sie mich immer wieder.

19. In meinem damaligen Körper sprach ich meinen König in deutlichem Gurānī an.

20. Seitdem ich in diesen Körper gekommen bin, bin ich gezwungen, Türkisch zu reden.

21. Ich bin der Sohn von Quščı Yäeūb, ich bin der Diener von Säyyed Ibrāhīm.

22. Ich widmete mein Leben den Yārān. Sie (die Heiden und Gegner Gottes) stellten mich vor der Öffentlichkeit zur Rede.

\footnotetext{
${ }^{151}$ Näsīmī ist der Name eines Dichters, der auch ein Anhänger der Yārıstān war. Er wurde im Jahr 837 (1433) nach Befehl des Mullāhs in Schiraz hingerichtet: seine Haut wurde ihm abgezogen, mit Heu gefüllt und über dem Stadttor aufgehängt (vgl. Dehkhoda 1968, Band 47, S. 492; Moradi 1999, S. 42, 46, 119).

${ }^{152}$ Häläb ist eine Großstadt in Šām.

${ }^{153}{ }^{\grave{S} a ̄ m}$ ist heutzutage zwischen Jordanien, Syrien, Libanon und Israel aufgeteilt.
} 


\section{Kälām Nr. 47}

1. gäl äy mä nā ähli Ärkāndan xäbär vır

2. vujūüünda nä var ondan xäbär vır

3. däryāya girdun gövhär čuxardun

4. șärrāfuna gostär ondan xäbär vır

5. Ṭūbā aqâjınun nädor mīvası

6. onun gülčičäk bārundan xäbär vir

7. bir aqaĵdor onun qirxdur budag் 1

8. onun här šāxsārundan xäbär vır

9. Quščıoglı jähhd it yāra yanaš

10. yāra yanašdun Xāndan xäbär vır

1. Komm, du ehrlicher Freund, der Freund der Wahrheit, berichte uns über die Ärkānn ${ }^{154}$

2. Was es in deiner Existenz gibt, berichte uns darüber.

3. Du bist in das Meer getaucht, um die Perlen zu sammeln.

4. Zeige diese Perlen dem Perlenkenner ${ }^{155}$ und berichte dann darüber.

5. Was für Früchte bringt der Ṭūbā-Baum ${ }^{156}$ ?

6. Berichte über seine Blüten und Früchte.

7. Der ist ein Baum, der vierzig Äste ${ }^{157}$ hat.

8. Berichte von seinen einzelnen Ästen.

9. Quščioġl1! Versuche, den Yār zu erreichen.

10. Wenn du ihn erreichst, dann berichte vom Xān (Ähmäd) ${ }^{158}$.

\footnotetext{
${ }^{154}$ Ärkān (oder Ärkān-e yārī) bedeutet die gesamten Rituale, die Ordnung innerhalb der Yārıstān, der Pakt und die Verpflichtung, die unter Kontrolle Bınyāmīns sind.

${ }^{155}$ Mit „Meer“ ist hier die Kälāmāt, mit „Perle“ das Kälām und mit „Perlenkenner“ derjenige, der die Authentizität des Kälāms feststellen kann, gemeint.

${ }^{156}$ Der Ṭūbā-Baum ist der Baum der Glückseligkeit im Paradies.

${ }^{157}$ Mit den „,vierzig Ästen“ des Ṭūbā-Baums sind hier die Vierzig Personen gemeint.

${ }^{158}$ Xān Äḥmäd ist eine Inkarnation von Šah Ibrāhīm und der Gründer der Xān Äḥmädī-Xānıdān.
} 


\section{Kälām Nr. 48}

1. gāafil olma Xidmätundän Šāh-1 jähān guz̄ār eylär

2. geja günduz ż1krida ol sänä räḥmät nıżār eylär

3. kimsähdan čäkma ändīša yoxı var eylär varı yox

4. Pādıšāhin meylı olsa qiš movsimin bähār eylär

5. Äränlär süknāsunda baš vıränlär čixarlär mäydān bašına

6. kim ki bu yolda șidqilän baš o jānin nis̄ār eylär

7. väqt o väedanı bir eylär ayilan gün birbirin tutar

8. goturür pärdähni yuzdän gejani häm nähār eylär

9. kim ki Häqqa iqrār eylär tärk-1 nāmūs o ‘ār eylär

10. änäl-ḥäqq Mänṣūr täk süĵda payını Dār eylär

11. kim Kä banin ẹvin yixär kim goyola āzār eylär

12. Häqqini yuzbeyuz görär Xidmätin bīgüftār eylär

13. kim țālibdur pärvāna tak jānin ota nisāâr eylär

14. dāyim müškila dušända Pīr därına hävār eylär

15. Bınyāmīn Šärțindän ayrı mīzān sorub gedän kimsa

16. älbätta onun Dīvānın äzīz Xāvändı̄ār eylär

17. Pādıšāhdan buyurduq oldı čix jāarla Quščınun og̉lı

18. Xōjäm gälür käräm usta uzuni āšıkār eylär

1. Vernachlässige deine Rituale nicht. Der König der Welt kommt zu dir.

2. Flehe am Tag und in der Nacht. Er schenkt dir die Aufmerksamkeit in Barmherzigkeit.

3. Fürchte dich vor niemandem. Er erschafft aus dem Nichtsein die Existenz und aus der Existenz erschafft er das Nichtsein.

4. Wenn der König will, erschafft er den Frühling aus dem Winter.

5. Die Opferbereiten (Yārān) kommen aus der Siedlung der Sieben Wesen und stehen auf dem Schlachtfeld.

6. Diejenigen, die auf diesem Weg sind, sind aufrichtig, sie schenken ihre Köpfe und ihr Leben dem König der Welt.

7. Er (der König der Welt) vereinheitlicht die Zeit mit dem Zeitpunkt zu einem versprochenen Termin, wenn der Mond und die Sonne einander erreichen.

8. Er nimmt die Schleier von seinem Gesicht und erhellt die Nacht zum Tag.

9. Derjenige, der sich zur Wahrheit bekennt, verliert das Ansehen in der Gesellschaft. 
10. Dieser Yār betet zum Galgen wie Mänșūr und auf diesem Wege bekommt er seinen Anteil vom König.

11. Es gibt diejenigen, die die Kaaba ruinieren, und so zerstören sie ihre eigene Existenz.

12. Es gibt aber diejenigen, die ihre Wahrheit von Angesicht zu Angesicht treffen und ihre Rituale vollziehen.

13. Es gibt jemanden, der nach der Wahrheit sucht wie ein Schmetterling, der sein Leben dem Feuer schenkt.

14. Wenn solch ein Mensch von Schwierigkeiten betroffen wird, ruft er nach Hilfe an der Tür des Pīr.

15. Derjenige, der den Pakt Bınyāmīns verachtet und seinen eigenen Weg geht,

16. Wird gewiss vor dem Gericht des geliebten Xāvändigār stehen.

17. Eine Nachricht kam vom König. Quščiog̀l1, lauf hinaus und verbreite diese Nachricht:

18. Mein Herr kommt und aus seiner Großmütigkeit enthüllt er sein Gesicht. 


\section{Kälām Nr. 49}

1. därdimä istäräm bu jämdän tīmār

2. šäfāsin eylasun Šāh Xāvändigār

3. müškilda qoymasun Dāvūd aqasi

4. yārānlär süĵda Ḥäqqador var Ḥäqqa yalvar

5. käräm äyähsı sänsän muruvvätun čoxdur

6. sayruya šäfā vır Šāh Xāvändıār

7. äluz Xıdmätda olsun gozuz yolda

8. Xıdmätozi eylasun pāk-1 Äräzbār

9. Äränlär sīnasi Ḥäqqin ẹvidor

10. yārānlär goyluza gäturmäyun gubār

11. Äränlär Häqqini jäämda görobdur

12. yārānlär siz olun Häqqdän xäbärdār

13. Nämāmä yalvarur Xān Äḥmäd hävār

14. sayruya istäräm bu jämdän tīmār

1. Ich verlange von diesem Jam die Heilung für meine Schmerzen.

2. Ich wünsche mir, dass Šāh Xāvändıgār meine Schmerzen lindert.

3. Der Herr von Dāvūd (Šāh Xāvändıāar) verlässt mich in den Schwierigkeiten nicht.

4. Yārān, wir verneigen uns vor der Wahrheit. Kommt, fleht die Wahrheit an!

5. Du (Gott) bist der Herr der Großmütigkeit, dein Edelmut ist groß.

6. Šāh Xāvändıgār, gib dem Kranken die Heilung!

7. Seien eure Hände bei dem Ritual (erfüllt ihr die Rituale) und erwartet ihr in jedem Augenblick die Ankunft Gottes.

8. Ich hoffe, dass Pāk Äräzbār (Rämzbār) eurem Ritual beisteht.

9. Das Herz der Sieben Wesen ist die Behausung der Wahrheit.

10. Freunde der Wahrheit! Lasst eure Wünsche nicht verstauben.

11. Die Sieben Wesen sehen im Ĵ̈m ihre Wahrheit.

12. Freunde der Wahrheit, seid ihr von eurer Wahrheit benachrichtigt.

13. Nämāmä ${ }^{159}$ betet flehentlich Xān Äḥmäd an und ruft nach seiner Hilfe

14. Bei der Heilung der Kranken aus diesem Jäm.

\footnotetext{
${ }^{159}$ Nämāmä ist der Name des Dichters dieses Kälāms.
} 


\section{Kälām Nr. 50}

1. Āšinālärin Xudāsindän `ālämlär iḥtyāṭ eylär

2. kim ki sär sälāmätdor yäqīn bil i i tiqād eylär

3. Qurān yalan däyur billā bıḥäqq-1 ān Kälāmullā

4. Muḥämmäddor Räsūlullā 'ālämda mü ĵizāt eylär

5. Qurān yalan däyur ḥäqqdor 'ālämlär ona müštāqdor

6. mindän birisi gustāxdur Mūsā tak kälämāt eylär

7. olar bizim dīnı bilmäz bu miḥrāba süjūu qılmäz

8. olar bizim yola gälmäz gärībdor iḥtyāṭ eylär

9. durub butxānaya varsam varub meyxānaya girsäm

10. šärāb ičub tovḥīd q1lsäm deyällär ki Hậââat eylär

11. Pīr Mūsīdor qälämyazan münkir olan Yoldan azar

12. Binyāmīn donbadon gäzär 'Īsā täk șuhäbāt eylär

13. Quščıoglınun Xudāsindän yäqīn bil i tiqādindän

14. leyl o nähār pīšasidor bāš yerda münājāat eylär

1. Die Welten sind vor Sulțān Säḥāk achtsam.

2. Sei sicher, dass derjenige, der gesund ist, bestimmt ein Gläubiger ist.

3. Der Koran ist keine Lüge, das schwöre ich bei Gott! Das Wort Gottes ist dafür eine Bestätigung,

4. Dass Muhammad der Prophet Gottes ist und in der Welt Wundertaten vollbringt.

5. Der Koran ist keine Lüge, er ist wahr: Universen sehnen sich nach ihm.

6. Nur einer von Tausenden ist so frech wie Mūsā (Moses), und seine Worte drücken etwas anderes aus (als die islamischen Worte).

7. Sie (die Muslimen) wissen von unserer Religion gar nichts, sie beten nicht in Richtung unserer Mihrab ${ }^{160}$ (sie akzeptieren unsere Rituale nicht).

8. Sie gehen nicht unseren Weg, sie sind Fremde, sie haben Angst.

9. Wenn ich in den Götzentempel hineingehe, wenn ich in ein Schankhaus eintrete,

10. Und trinke und wie ein Betrunkener, der nur die Wahrheit sagt, und bestätige, dass es nur einen Gott gibt, dann wird gesagt, dass ich das Notgebet ${ }^{161}$ lese.

11. Pīr Mūsī ist der Schreiber des Himmels. Und wenn jemand dieses nicht akzeptiert, dann ist er ein Apostat und wird seinen Weg verlieren.

\footnotetext{
${ }^{160}$ Mihrab - eine Nische in der Moschee, die die Richtung nach Mekka zeigt.

${ }^{161}$ Das Notgebet (do`ā-i ḥầ̂âat - arab.) ist ein islamisches Gebet.
} 
12. Binyāmīn wandelt von Körper zu Körper und wie Jesus ${ }^{162}$ hält er vor den Menschen seine Rede.

13. Sei sicher, dass Quščığlı an Gott glaubt.

14. Seine Beschäftigung ist es, sich Tag und Nacht auf die Erde zu verbeugen und Gott anzuflehen.

${ }^{162}$ Die Yārıstān-Gläubigen meinen, dass Jesus eine Inkarnation Bınyāmīns ist. 


\section{Kälām Nr. 51}

1. ḥukumlı Pādıšāh čixär jähāna bir eädl o dād eylär

2. silär güzgulärin pasin yengi bašdan bir ad eylär

3. bu bir sulțān bähādurdor kimsa yayin čäka bilmäz

4. muxännäșin oxı batmaz häạāininı fūlād eylär

5. Tari gogdän yera änär istär mu'minlärı gora

6. girär ādam qālibina özun bändașifāt eylär

7. o Sulțānun ḥukumundän härdu däst-1 qüdrätindän

8. bir älın räḥmäta vermiš bir älın syāsät eylär

9. bu bir kärīm purkärämdor gečär daġlar günāhlardan

10. o räḥmät bāqī günunda nečča qullar āzād eylär

11. bašları äyaq eylär äyaqları baš eylär

12. alür mäżlūmlarun dādın bu dä vānı ābād eylär

13. bu bir behtär olar nūrsa șālı̣̣ movjūũd olürsa

14. durub qolların salürsa oyuna kırāmāt eylär

15. jähānı ḥukmuna alür šäțränĵ1 oyuna salür

16. roxun reyḥān alür satür mātilän kıšmāt eylär

17. xōjääm älında āsāndor uzaq1 yavoq eylämäk

18. sāeätı min ila bag̉lar min ilı bir sāeät eylär

19. bu bir Sulțān-1 `Ālämdor ačobdor dīn-1 Islāmi

20. räḥmätollā ona oxurlar zämāna da yād eylär

21. soyun Quščığlı soyun itirma Ähl-1 Häqq yolun

22. xōjäm gälür käräm usta tanyanları šād eylär

1. Der mächtige, Befehl erteilende König kommt auf die Welt, er schafft das Gesetz und die Gerechtigkeit.

2. Er wischt den Staub von den Spiegeln. Er bekommt erneut einen berühmten Namen.

3. Er ist ein tapferer König, dessen Bogensehne niemand spannen kann.

4. Der Pfeil des Feiglings trifft das Ziel nicht, weil der König seine Festung aus Stahl macht.

5. Gott steigt vom Himmel herunter. Er will die Gläubigen sehen.

6. Er tritt in der Gestalt eines Menschen auf, er zeichnet sich mit den Eigenschaften eines Menschen aus.

7. Der König erteilt seine Befehle und hat zwei mächtige Hände: 
8. Mit der einen Hand begnadigt er, mit der anderen Hand bestraft er.

9. Er ist ein Barmherziger voll von Gutmütigkeit. Er verzeiht die Sünden, die groß wie Gebirge sind.

10. Die Reste seiner Gnade reichen aus, um mehrere Diener zu befreien.

11. Er kehrt das Obere nach unten und das Untere nach oben.

12. Er gibt Gerechtigkeit den Unterdrückten und regelt die Gesetze.

13. Wenn ein Gewalttätiger sich bessert und zu einem guten Wesen wird,

14. Aufsteht, und die Bereitschaft zeigt, sich zu bessern, dann wird Gott ihm gegenüber auch gutmütig werden.

15. Er hielt die Welt unter seinem Befehl, wie ein Schachspieler auf dem Schachbrett.

16. Sein Turm macht Geschäfte mit dem Basilikum (er spielt mit dem Turm sehr locker), überrascht damit seinen Gegner und setzt ihn schachmatt.

17. Es ist für meinen Herrn einfach, die Ferne näher zu bringen.

18. Er macht eine Stunde so lang wie tausende von Jahren und tausende von Jahren so kurz wie eine Stunde.

19. Er ist der König der Welt. Er hat den Islam ins Leben gerufen.

20. Alle beten ihn an. Das Zeitalter steht ihnen bei.

21. Sei froh, Quščığlı, sei froh! Verliere den Weg der Freunde der Wahrheit nicht!

22. Mein Herr kommt aus seiner Barmherzigkeit zu denen, die ihn kennen und macht sie fröhlich. 


\section{Kälām Nr. 53}

1. biza Yārdan ayrı āvāra deyällär

2. jigärim šärḥa šärḥa pāra deyällär

3. nä mänım därdıma qilällär dävā

4. nä därd-ı dılımı o Yāra deyällär

5. fägān o zārīmi kimsa ẹ̌sitmäz

6. mänä dilxästa-ı bīčāra deyällär

7. kimsänä bilmäz mänim ḥāl o zārīmi

8. mänä dälı olmuš āvāra deyällär

9. uzaq yollärımı gätdun yavoqa

10. doldor sāqī vır xümāra deyällär

11. bir gäzär boyun gordom Pādıšāhım

12. tanyanlar yolunda Kä ba deyällär

13. Quščıg̉lı istärsän yarava märḥäm

14. gäna öz Yārundan čāra deyällär

1. Ohne Yār nennt man uns heimatlos.

2. Mein Leber (Herz) ist zerrissen, man sagt aber, dass es nur eine Verwundung ist.

3. Man gibt mir weder ein Heilmittel,

4. Noch erzählt man meinem Yār meine schmerzhafte Geschichte.

5. Niemand hört meine Wehklagen und mein Schreien.

6. Man nennt mich einen Elenden, einen Hoffnungslosen mit gebrochenem Herzen.

7. Niemand versteht meinen traurigen Zustand.

8. Man nennt mich einen irren Obdachlosen.

9. Du verkürztest meinen langen Weg

10. Und jetzt fülle, du Mundschenk, meinen Weinbecher und gib ihn dem Berauschten.

11. Ich sah einmal die Gestalt meines Königs.

12. Diejenigen, die ihn gekannt haben, nennen diese Begegnung „Kaaba“.

13. Quščiog̀l1, wenn du für deine Verwundung die Heilsalbe suchst,

14. Suche das Heilmittel weiterhin bei deinem Yār. 


\section{Kälām Nr. 56}

1. Ādäm-1 Șäfī deyällär läqäbi bir ada bänzär

2. män ‘išqi Yāra gätordom xod özı mürāda bänzär

3. dedılär Xudānun žāt o șifātı nıččadur

4. șifätı Ādäm șifätı ḥädd o qädı hāda bänzär

5. dedılär Xudānı tutmusan yā oturmusän

6. yerıdum Xudānı tutdum äbäd-alābāda bänzär

7. dedım Pīrim `Ālīdor Qirxlär ičinda välīdor

8. sag älında sāgär sāndım sol älında bāda bänzär

9. dunyāya soyoq yel äsär Äränlär șuḥbätın käsär

10. dunyānun särd olduqundan āšınālär yāda bänzär

11. dunyānun yoxdur väfāsı xūblarun čoxdur jäfāsı

12. dunyānun gälub gıdıšı būrānilän bāda bänzär

13. dedılär Quščioġluna čox zämāna ‘āšiqisän

14. zämāna o zämāna däyur sāeät o sāeäta bänzär

1. Man sagt, dass der Beiname Adams (des ersten Menschen) ein gewöhnlicher Name ist.

2. Ich brachte die Liebe zum Yār. Diese Liebe ist selbst wie ein erfüllter Wunsch.

3. Die anderen sagten: „Gott hat verschiedene Eigenschaften und Charaktere“.

4. Seine Eigenheiten sind wie die der Menschen, seine Größe und Gestalt sind aber wie ein Schatten.

5. Es wird gefragt, ob ich Gott annehme oder ablehne?

6. Ich ging und wählte Gott für ewig.

7. Ich sagte, dass mein Pīr 'Ālī, der einer der Vierzig Personen ist, dass der der Freund Gottes unter den 40 ist.

8. Seine rechte Hand rechne ich als einen Weinbecher und seine linke Hand sieht wie Wein aus.

9. Es weht ein kalter Wind auf der Welt, die Sieben Wesen hören auf, zu sprechen.

10. Die Welt war früher kalt und nur die Kenner erinnern sich daran.

11. Die Welt ist nicht treu (ist vergänglich) und die Schönen sind Peiniger.

12. Der Umgang der Welt mit den Menschen sieht wie Wind und Schneesturm aus. 
13. Es wurde Quščıg

14. Die Zeiten ändern sich, obwohl die Stunden ähnlich scheinen. 


\section{Kälām Nr. 60}

1. Yārānlär ovlī Xānı istärlär

2. yerin göyun äyäsı Sulțānı istärlär

3. minbir donilan čixdı jähāna

4. Pīrdīvärdän gälän donı istärlär

5. münĵa ki baxaram barča fänādor

6. äbäd-albāqīidor onı istärlär

7. Bınyāmīnilän qoyub Šärṭ-1 Bäyābäst

8. Dāvūda göndärän šunı istärlär

9. här kimin sıkkası durustdor Qänbär

10. Dīvān išinda onı istärlär

1. Die Yārān lieben den prächtigen Xān (Äḥmäd).

2. Sie lieben den Herrn der Erde und des Himmels, den Sulțān (Sulțān Sähāa).

3. Dieser (Sulțān Säḥāk) kam auf die Welt in tausend und einer Gestalt.

4. Seine (letzte) Gestalt (als Sulțān Säḥāk), die bei Pīrdävär erschien, lieben sie.

5. Was ich sehe, ist vergänglich.

6. Das, was ewig und unvergänglich ist, das lieben sie.

7. Er (Sulțān Sähāk) schließt mit Bınyāmīn in Bäyābäst einen Pakt.

8. Denjenigen, der Dāvūd die Regeln und die Ordnung schickt, den lieben sie.

9. Du Qänbär ${ }^{163}$, weißt Bescheid, dass wer einen perfekten Schnurrbart hat, 10. Im Dīvān Gottes (Gerichtshof Gottes) geliebt wird.

\footnotetext{
${ }^{163}$ Qänbär ist der Name des Dichters dieses Kälāms.
} 


\section{Kälām Nr. 62}

1. İbrāhīm näżärında bilin ki Quščıoġlıdor

2. gūyända-1 Häqīqät bilin ki Quščıg̉lıdor

3. baš adı Bınyāmīndor Xōjäm qatonda

4. läqäbı Däftärlärda bilin ki Quščıg

5. hıč ‘āšiq Däftärin rämzını bilmädı bašdan

6. Xōjäm ämrilän deyin bilin ki Quščığlıdor

7. yeddı ärxa donbadon barča gūyända

8. gülām-1 Qänbär Qulog̉ı bilin ki Quščığglıdor

9. Šähsävārog̀lı Qāsım Mäzīdoġlı Ämīr da

10. Häsän ‘ Âlī Türābī bilin ki Quščığlıdor

11. o ki ičdı Xōĵası älındän äsrädı där däm

12. näfäsındän durr sačılan bilin ki Quščığlıdor

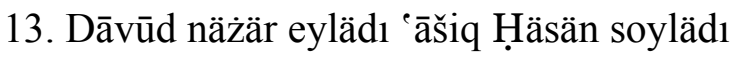

14. gūyändalär ustādı bilin ki Quščığlıdor

1. Wisst, dass Ibrāhīm (Šāh Ibrāhīm) seine Aufmerksamkeit auf Quščioġlı lenkt.

2. Wisst, dass der Dichter der Wahrheit Quščığlı ist.

3. Bınyāmīn ist der erste Name auf der Liste meines Herrn.

4. Wisst, dass derjenige, dessen Beiname in den Heften erwähnt wird, Quščığlı ist.

5. Kein Verliebter (kein Yār) kennt das Geheimnis der Hefte von Anfang an.

6. Wisst, dass es Quščığlı ist, der nach dem Willen Gottes zum Dichter wurde.

7. Die sieben vorigen Verkörperungen von Quščığlı sind Dichter.

8. Wisst Bescheid, dass die Knechte, die Qänbär und Qulog̉ı heißen, sind Quščığlı.

9. Dazu kommen auch Šähsävāroġlı, Qāsım, Mäzīdoġli und Ämīr.

10. Häsän, `Ālī und Turābī sind auch Quščığlı.

11. Derjenige, der von seinem Herrn einen Weinbecher nahm und sich sofort betrank,

12. Danach blühten die Perlen von seinem Atem auf (er dichtete seine Kälāmāt), war auch Quščioġl1.

13. Dāvūd lenkt seine Aufmerksamkeit darauf, was Häsän ${ }^{164}$ in diesem Gedicht sagt:

14. Wisst, dass der Meister aller Dichter Quščıg

\footnotetext{
${ }^{164}$ Der Name des Dichters dieses Kälāms.
} 


\section{Kälām Nr. 92}

1. Yārānlär gälun Kälām o Däftär mändador

2. gözövuzı ačun kān-1 gövhär mändador

3. Qävälțās Mīčası üč gün Oroĵdor

4. o yeddı geja Xıdmätdor Xıdmät mändador

5. Bınyāmīna hü̈km oldı o Xıdmätı bäxš etdı

6. Dāvūd täkbīr čaldı Šärț-1 Häqīqät mändador

7. Hävizanı dästmālı siz gätorun

8. siz Kırdār eyläyun Ĵovz-1 Häqīqät mändador

9. Quščığlı jārla țālıb išidsun

10. mäğrıbdän mäšrıqa Ärkān-1 Ḥäqīqät mändador

1. Kommt, Yārān, das Kälām und die Hefte sind bei mir.

2. Öffnet eure Augen: die Quelle von Perlen ist bei mir.

3. Drei Fasten-Tage sind der Teil von Qävālțās.

4. Es sind sieben Nächte von X1dmät, und X1dmät selbst ist bei mir.

5. Es wurde dem Binyāmīn befohlen, das Xıdmät zu verteilen.

6. Dāvūd segnete und sagte, dass der Pakt der Wahrheit bei mir ist.

7. Bringt die Geldmünze und das Handtuch mit.

8. Macht Kırdār ${ }^{165}$, weil der Ĵouz (Muskatnuss) von Bınyāmīn bei mir ist.

9. Quščioġlı spricht laut, um von den Suchenden gehört zu werden:

10. Vom Westen bis zum Osten ist die Basis der Wahrheit bei mir.

${ }^{165}$ Kırdār (pers. „Tat“) ist ein Begriff im Yārıstān-Lexikon für die Speisen im Jäm. Hier wird eine Speise für die Särsepārī-Zeremonie gemeint. 


\section{Kälām Nr. 96}

1. Yār Yāra bädxōh zämān olaĵaqdor

2. żuhūra yaxon illär yaman olajaaqdor

3. dūstila dušman mä lūm olmaz onda

4. yalanči zāhıdlär bädgumān olajaqdor

5. häyā o hürmät gıdär qalmaz arada

6. xälqin biza dedıgı buhtān olajaaqdor

7. kīn o kudūrät-1 däĵjāâl tutar jähānı

8. doġrila yalan ‘äyān olaĵaqdor

9. inșāf o mürüvvät gıdär dünyādan

10. Tärāzū qurulub mīzān olaĵaqdor

11. šäkkdār olanlär Ḥäqqa irišmäz

12. olara iftırā demaq invān olaĵaqdor

13. yer yuzun nāhäqq buhtānlar tutar

14. jäng o ĵdāal-1 šāhān olajaaqdor

15. dünyā qarıšür šärq1dän gaärba

16. qanlär kūh o șährāda rävān olajaaqdor

17. yeddı gün. yeddı geja żülämāt olür

18. qušun birbirin qırmaqa imkān olajaaqdor

19. däryānun yuzun kıštîlär tutar

20. Qiyāmät o gün țüğyān olajaqdor

21. bir ag̉or läšgär gälür Čīn țäräfındän

22. qušun birbirına dägär fägāan olajaqudor

23. yeddı pādıšāh qirx yerda vurar urdū

24. läšgär yıq1lub o gün bir sān olajaqdor

25.bašlar tökölub jääädlär qalür yerda

26. günähkār olanlar gıryān olaĵaqdor

27. Mäkka o Mädīna olar mänzılgāh

28. qätl o gāärät o talan olajaqdor

29. țäbl-ı gırān vurulür yeddı iqlīmdän

30. komäk Rus o Turka İrān olajaqudor

31. büxl o iidāvät tämām tutar jähānı

32. qara yel äsub țūfān olajaaqdor

33. rizq tapulmaz küfr tutar jähānı 
34. mäxlūqun xūrākı häyvān olajaqdor

35. qirx gün qirx geĵa čišmalar qurür

36. jümla xälāyıq eäț̌sān olajaaqdor

37. čādur čādurdän birbir gıčärlär

38. pādıšāhnıšīn Zänĵān olaĵaqdor

39. yer o gög tıträhšür 'äql olür zāỳ ${ }^{`}$

40. däšt-1Xürāsān al qan olaĵaqdor

41. `ärșa täng olür ähl-1 İrāna

42. häm o väqt xärāba Kırmān olaĵaqdor

43. bıš gün bıš geĵa qilič vurulür

44. gögdän ot yaġar äfs̃ān olaĵaqdor

45. hıč dīn ählı öz yolunda durmaz

46. Ḥäqq ṭäräfındän bir ovlī färmān olajaqdor

47. yeddı sävāra o väqt čixär żuhūra

48. olara mänzıl avjān olajaqdor

49. tūp o tüfäng ačulmaz Häqqin ämrilän

50. o väqt Zülfäqār bürrān olajaqdor

51. Zülfäqārun šovq1 tutar jähnāi

52. münkırlär qälbı šanšan olajaaqdor

53. bāṭın atlusı čixär żuhūra

54. İsrāfîl Ṣūrin čalan olajaqdor

55. mäğrıbdän mäšrıqa Ṣūrun säsı yetišür

56. tämām mürdalär durub häyrān olajaqdor

57. täxt-i zıbärjäd qüdrätdän qoyulür

58. üstünda äglähšän Šāh-1 märdān olaĵaqdor

59. lüțf-1 Šāh-1 märdān tutar jähānı

60. oväqt därda dägän īmān olajaaqdor

61. qirx gün q1rx geĵa at üsta gäzär

62. rıkābin tutan Sälmān olajaqdor

63. Pīr Mūsī däftärīn salür araya

64. doqsanmin Gülām nämāyān olaĵaqdor

65. Häftän o Häft/tävān Čıltän čıär żuhūra

66. o väqt bir ‘äjāyıb dovrān olaĵaqdor

67. Häqīqät beydäq1 o väqt gälür meydāna 
68. tämām münkırlär görända pešmān olaĵaqdor

69. här kimsa gär görsa Mövlā jämālın

70. pīr olsa ägär jävān olajaaqdor

71. biza tühmät vuran münkır fäqīhlär

72. Ḥäqq Dīvānın göröb härāsān olajaqdor

73. zāhıd o münkır Häqq1 danannar

74. jämālın görjäk lärzān olaĵaqdor

75. Häqīqät Dīvānı o väqt qurulür

76. jümla Yāränlärın därdına därmān olajaqdor

77. hạaqqila nāḥäqq o väqt sıčilür

78. Dāvūd qäțārında dovrān olaĵaqdor

79. här kimin ürägda sırr var Häqqdän

80. Ḥäqqına yetän Kırdār o iḥsān olaĵaqdor

81. ähl-1 inkārın dīn o īmānı olmaz

82. q1smät olara zındān olajaaqdor

83. tämām münkırlär bända vurulür

84. xā’yn-1 dīn nıšān-1 peykān olajaqdor

85. dīn-1 Häquīäät rävāĵ olür `ālämda

86. ähl-1 Häqqlär hamusı xändān olajaqdor

87. Pīrdīvärda qoyolan Šärṭ o Šun

88. āšıkāra čıxub dünyā riẓvān olajaqdor

89. Jäm-1 Häqīqät qurulür Häqqin ämrilän

90. baš o jāandan gičän Yāristān olaĵaqdor

91. jüumlası šād olür tutar Čäp-1 Däst1

92. Häqq1 Jämda görob šādān olaĵaqdor

93. Sulțān Sähāk ämrıdor Quščınunoġlı

94. Šāh İbrāhīm säna mıhmān olaĵaqdor

1. Es wird eine Zeit kommen, in der die Yārān untereinander Feinde werden.

2. Kurz bevor Sulțān Sähāk erscheinen wird, kommen sehr schlechte Jahre.

3. In dieser Zeit wird es unmöglich sein, einen Feind von einem Freund zu unterscheiden.

4. Die lügenden Asketen werden misstrauisch werden.

5. Ehre und Scham verschwinden völlig, bis nichts davon übrig bleibt. 
6. Alles, was die Leute über uns sagen, wird Verleumdung sein.

7. Feindschaft, Missverständnis und Hass von Däjj̄āa ${ }^{166}$ werden die Welt regieren.

8. Alles, was wahr ist, wird als Lüge betrachtet werden.

9. Gerechtigkeit und Gutmütigkeit werden aus der Welt verschwinden.

10. Die Waage wird aufgestellt und das Maß festgelegt.

11. Die Zweifelnden erreichen die Wahrheit (Gott) nicht.

12. Sie werden angeklagt und vor das Gericht gerufen.

13. Die Verleumdung wird die Welt beherrschen.

14. Die Könige werden gegeneinander kämpfen.

15. Von Osten bis Westen wird die Welt chaotisch sein.

16. Viel Blut wird auf den Gebirgen und in den Steppen fließen.

17. Dunkelheit wird während 7 Tagen und 7 Nächten die Welt bedecken.

18. Wegen der Dunkelheit können die Armeen sich selbst niedermetzeln.

19. Das Gesicht des Meeres wird mit Schiffen bedeckt sein.

20. Der Wirrwarr erreicht an diesem Tag seine Spitze.

21. Eine mächtige Armee kommt aus China.

22. Die Armeen stoßen aufeinander. Das Wehklagen wird überall zu hören sein.

23. Sieben Könige werden in 40 Schlachtfeldern ihre Lager aufschlagen.

24. An dem Tag werden die Armeen eine Parade halten.

25. Köpfe werden fallen und Leichen werden auf dem Boden liegen bleiben.

26. Die Sünder werden weinen.

27. Mekka und Medina werden zu Armeestationen.

28. Eroberung, Verbrechen und Mord werden zum Alltag gehören.

29. Es wird auf den sieben Erdteilen laut getrommelt werden.

30. Iran wird den Russen und den Türken helfen.

31. Geiz und Feindschaft werden das Weltall beherrschen.

32. Ein schwarzer Wind wird wehen und es wird einen Sturm geben.

33. Es wird keine Nahrung zu finden sein. Ketzerei wird die Welt regieren.

34. Die Tiere werden von den Menschen verspeist werden.

35. Die Brunnen werden 40 Tage und 40 Nächte kein Wasser geben.

\footnotetext{
${ }^{166}$ Däĵ̄āl (arab.) bedeutet „Antichrist, der vor dem Endgericht auf einem Esel erscheint und viele Schaden anrichtet, bis der „verborgene Imam“ ihn besiegt; Schwindler, Betrüger, Usurpator“ (vgl. Junker/Alavi 1363 (1984), S. 301).
} 
36. Alle Geschöpfte werden durstig sein.

37. (Die militärischen Einheiten) werden Zelt für Zelt besiegt.

38. Die Stadt Zänjān wird zum Hauptsitz des Königs.

39. Erde und Himmel werden beben. Die Vernunft wird verfallen.

40. Die Steppen in Chorasan(iran.Ostprovinz)werden voll Blut sein.

41. Die Iraner werden in eine bedrängte Lage geraten.

42. Die Stadt Kırmān wird in dieser Zeit zerstört werden.

43. Der Säbelkampf wird 5 Tage und 5 Nächte dauern.

44. Feuer wird vom Himmel fallen.

45. Kein Gläubiger wird an seinem Glauben festhalten.

46. Ein heiliger Befehl wird von der Wahrheit (Gott) erteilt werden.

47. Die 7 Reiter (die Sieben Wesen) werden in dieser Zeit erscheinen.

48. Ihr Lager wird auf den Spitzen (im Himmel) aufgeschlagen.

49. Kanonen und Gewehre werden nach dem Willen der Wahrheit nicht mehr schießen.

50. Das Schwert ' $̈$ Älīs ${ }^{167}$ wird noch schärfer werden.

51. Die Strahlung vom Schwert `Älīs wird überall auf der Welt zu sehen sein.

52. Die Herzen der Apostaten werden zerrissen.

53. Ein esoterischer Ritter (Dāvūd) wird in dieser Zeit erscheinen.

54. Isrāfīl wird in seine Posaune blasen.

55. Die Posaune wird von Westen bis Osten zu hören sein.

56. Alle Gestorbenen werden aufstehen und staunen.

57. Ein königlicher Sessel aus Smaragd wird aufgestellt werden.

58. Der darauf Sitzende wird zum König der Männer ( $(\ddot{A} l \bar{i})$.

59. Seine Barmherzigkeit wird die Welt regieren.

60. Der Glauben wird in dieser Zeit nötig sein.

61. Er ( $(\ddot{A} 1 \overline{1})$ wird 40 Tage und 40 Nächte sein Pferd reiten.

62. Sälmān ${ }^{168}$ wird seinen Steigbügel halten.

63. Pīr Mūsī wird sein Heft vorlegen (das Geschehene wird von ihm, dem Schriftsteller der Sieben Wesen, festgehalten).

64. 90 tausend Knechte werden sich zeigen.

65. Die Sieben Wesen, die Sieben Mächte und die Vierzig Personen werden erscheinen.

66. Dann beginnt die Wunder-Ära.

\footnotetext{
${ }^{167}$ Das Schwert ${ }^{\circ}$ Älīs ist dafür bekannt, dass es zwei Schwertblätter hatte.

${ }^{168}$ Sälmān der Perser war einer der treuesten Freunde `Älīs und Muhammads.
} 
67. Die Flagge der Wahrheit wird auf den öffentlichen Platz kommen.

68. Alle Ungläubigen werden dieses sehen und bereuen.

69. Wenn jemand das Gesicht `Älīs sehen wird,

70. Wird er wieder jung werden, wenn er alt war.

71. Die Asketen, die uns verleumdeten,

72. Werden den Gerichtshof der Wahrheit sehen und sich vor ihm fürchten.

73. Sowohl die Asketen, als auch die Ungläubigen werden die Wahrheit bestätigen,

74. Alle, die dein Gesicht zu sehen bekommen, werden erschüttert sein.

75. Der Dīvān (Gerichtshof Gottes) der Wahrheit wird in dieser Zeit erfolgen.

76. Alle Schmerzen der Yārān werden geheilt.

77. Das Wahre wird in dieser Zeit vom Unwahren unterschieden.

78. Nach der Anordnung von Dāvūd beginnt ein Zeitalter.

79. Diejenigen, die ein Geheimnis der Wahrheit im Herzen haben,

80. Werden eine ihrer Tat entsprechende Belohnung bekommen.

81. Die Ungläubigen haben weder Religion noch Glauben mehr.

82. Ihr Anteil wird ein Gefängnis sein.

83. Alle Ungläubigen werden gefesselt.

84. Der Religionsverräter wird zur Zielscheibe für Bogenschützen werden.

85. Die Wahrheitsreligion wird in der ganzen Welt Verbreitung finden.

86. Alle Yārān werden lächeln.

87. Der in Pīrdävär festgelegte Pakt und das bestimmte Gesetz

88. Werden der Öffentlichkeit bekannt gegeben. Die Welt wird ein Paradies werden.

89. Das Jäm wird nach dem Befehl der Wahrheit stattfinden.

90. Alle werden zu Yārān, die ihre Köpfe und das Leben opfern.

91. Alle werden fröhlich und veranstalten das Čäp-1 Däst-Fest ${ }^{169}$.

92. Sie begegnen der Wahrheit im Ĵ̈äm und werden fröhlich.

93. Quščığlı, es ist ein Befehl von Sulțān Säḥāk,

94. Dass Šāh Ibrāhīm als Gast zu dir kommen soll.

\footnotetext{
${ }^{169}$ Čäp-1 Däst (wörtlich „Handklatschen“) ist ein Bestandteil der Musik im Jäm-Xāna.
} 


\section{Kälām Nr. 103}

1. ävväldän varidim Kān o Mäkān olmadom hänūz

2. Ādäm șūrätında kāmıl insān olmadom hänūz

3. dünyā suiydi män özömda movĵūdidum

4. göglärin țänāb1 yerda mīzān olmadom hänūz

5. bäqādaydim dünyā bünyād olanda

6. `Äršilän Kursī `āläma därmān olmadom hänūz

7. nūridim sırridim qändīl ičinda

8. fäläkda šämsilän qämär rovšän olmadom hänūz

9. qändīldähidim żülumātda seyrān idirdim

10. Xi ẓičun Ĵām-1 jāàvıdān olmadom hänūz

11.ādämī šärīf yaratdı vujūùını gıldän

12. bihıštdaydim ādäm äṣlıma zyān olmadom hänūz

13. Ĵbrä'ylidim gäturdum Nūḥa xäbärı

14. dünyā țūfānikän țūfān olmadom hänūz

15. Ḥüseynīlärin nämāzı nyāza gıčdı

16. Q1bla mäsĵ1d o mınbär dovrān olmadom hänūz

17. yüzigirmidortmin näbīnin nūrı dušd1

18. Muhämmäd räsūl xätm-1 peyġämbärān olmadom hänūz

19. dört kıtābin mä’nāsı äzbärımdadur

20. Inĵ̄il o Tūrāt o Zäbūr o Fürqān olmadom hänūz

21. män `Äbdulmälıkäm bu mülk ičinda

22. yetmišikki milläta dil zäbān olmadom hänūz

23. hüusnova māyıläm mülkova šärīk

24. Yä qūb og̉lı Yūsıf kimi Miṣrda sulțān olmadom hänūz

25. İbrāhīmilän Kä’bänun bünyādın qöydum

26. İsmāệlilän earäfātda qürbān olmadom hänūz

27. doqsanmin käläma Häqqilan üz ba üz oldı

28. atmušmini Moḥämmäda ärkdān olmadom hänūz

29. män Qulog̉llyam gärdıšilän gäldım jähāna

30. ‘išq äsräk1 särmäst-1 jāàvıān olmadom hänūz

1. Von Anfang an war ich (Gott) schon da, aber ich war noch nicht zur Welt geworden. 
2. Ich war noch nicht in Gestalt des Adams zum vollkommenen Menschen geworden.

3. Die ganze Welt war noch nichts als Wasser, als ich schon da war.

4. Ich verband die Seile vom Himmel mit der Erde noch nicht, als ich schon da war.

5. Als die Welt zustande kam, war ich schon da.

6. Es gab noch keinen Pavillon Gottes, ich war noch kein Heilmittel für die Welt.

7. Ich war das Licht, das Geheimnis in einer Öllampe,

8. Obwohl ich den Mond und die Sonne noch nicht geschaffen hatte.

9. Ich war in der Öllampe und wanderte durch die Dunkelheit.

10. Ich war noch nicht für Elias (den Propheten) ein ewiger Becher (ewiges Leben) geworden.

11. Der Mensch war aus Lehm zu seiner edlen menschlichen Existenz.

12. Ich war im Paradies, als Adam den menschlichen Ursprung noch nicht beschädigte,

13. Ich war Gabriel (der Erzengel), ich benachrichtigte Noah (den Propheten),

14. Mit der stürmischen Welt war ich noch nicht zum Sturm geworden.

15. Das Gebet der Huseyn ${ }^{170}$-Liebenden ${ }^{171}$ wurde zum Nyā $z^{172}$.

16. Ich war noch nicht die Zeit für die Moschee, die Kaaba und das Minbar geworden.

17. Die Strahlung von 124 tausenden Propheten schien.

18. Ich war Muhammad, der letzte Prophet noch nicht geworden.

19. Ich konnte den Inhalt der vier Bücher auswendig,

20. Obwohl ich zu diesen vier Büchern - der Bibel, der Thora, den Psalmen (Davids) und dem Koran - noch nicht geworden war.

21. Ich bin ein Knecht des Königs dieses Landes.

22. Ich war noch nicht zur Sprache der 72 Völker geworden.

23. Ich liebe deine Schönheit und will an deinem Königreich teilnehmen.

24. Ich war noch nicht zu Joseph, dem Sohn von Jakob (dem Propheten), dem König in Ägypten geworden.

25. Mit Ibrāhīm gründete ich die Kaaba.

26. Mit Ismāê̄l war ich noch nicht in `Äräfāt geopfert.

\footnotetext{
${ }^{170}$ Ḥuseyn ist der Sohn von 'Ālī und ein der Körper von Bābā Yādıgār

${ }^{171}$ Huseyn-Liebende sind die Schiiten.

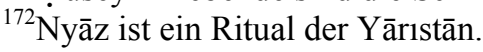


27. 90 tausend Worte trafen sich mit der Wahrheit.

28. Die 60 tausend davon, die die Grundlage für Muhammad sein sollten, war ich noch nicht geworden.

29. Ich bin Quloġl. Ich kam durch Seelenwanderung auf die Welt.

30. Ich war von der Liebe noch nicht für ewig berauscht. 


\section{Kälām Nr. 129}

1. Yārānlär män näyidim indi näya gälmišäm

2. äzäldän eylayidim indi beylaya gälmišäm

3. män bir quri aqaĵidum Xōĵm sačdı gögärdım

4. durrlo durrlo mīvalärdän bišibäm Jäma gälmišäm

5. män bir dilbilmäz lālidim öz ḥālima mälālidum

6. Šāh İbrāhīm söyla dedi indi söylaya gälmišäm

7. dünyānı dutdi tüxm-1 däĴ̂̃āl o Gürj̄̄

8. İslāma zūr oldi Ḥāqqa hävāra gälmišäm

9. baš Bınyāmīn bašidor läqäbım Quščığlidor

10. qālıblärdän qālıba seyrayelaya gälmišäm

1. (Wisst ihr), Yārān, welchen Körper und welche Aufgabe ich früher hatte und für welche Aufgabe ich nun gekommen bin?

2. Vom Anfang an war ich eines, und jetzt bin ich etwas anderes, das der heutigen Aufgabe auch entspricht...

3. Ich war ein trockener Holzstock. Mein Herr steckte mich in die Erde. Ich wuchs als ein Baum auf.

4. Jetzt bin ich die reife Frucht, die voll von Perlen ist, und komme in das Jäm.

5. Ich war ein Stummer und deswegen traurig.

6. Šāh Ibrāhīm sagte zu mir: „Sprich!“ Seitdem spreche ich. Ich bin jetzt ein Sprechender.

7. Die Rassen des Antichristen und die Georgier (die Ungläubigen) eroberten die Welt.

8. Der Islam wurde geschädigt. Ich kam, um Gerechtigkeit und Recht zu fordern.

9. Mein Kopf gehört Bınyāmīn (ich hatte Särsepārī), mein Beiname ist Quščioġl1.

10. Durch die Seelenwanderung bin ich von einem Körper zum anderen gekommen. 


\section{Kälām Nr. 130}

1. dünyāya gälmaqičun yār-1 bīdārı istäräm

2. därdıma därmān bilmaqa o xäbärdārı istäräm

3. â̂ däyüräm yalavâ̂ däyüräm kimsäya müḥtâj däyüräm

4. `ālämlära kird eylyän pärvärdıgārı istäräm

5. Uzumdälin Dikdaban Yeddiqädäm Qizqapanı

6. Älänĵa o Näxj̄ävānı Ordubād yārı istäräm

7. Gärgärdän bäri Zünüzı Ṣūfyānı Märändüzı

8. aššaqida Šänb-1 Ġazanı Täbrīzda yārı istäräm

9. Ārānda qalanları o `Eyn älīnun yārānlärı

10. Täräkäma illärinda čārvādār Yārı istäräm

11. Äräsbārān qišlaqunda tämām illär yeylaqunda

12. qišgünı tüklıdaġunda närgisbähārı istäräm

13. äzäl göstärdı yüzünı sora gizlätdı üzünı

14. rūz-1 Qyāmäta täk män o Dīdārı istäräm

15. Bäğdād qümašın sataram xäbär vırräm män otäräm

16. düšmüšäm šährıdän šähra Mihr-1 Nigārı istäräm

17. Quščığlınun bidıh bıstānı Yāriländor

18. Durr mäțāe lär sataräm bir xärīdārı istäräm

1. Ich wünsche mir einen wachsamen Yār, um auf die Welt kommen zu können.

2. Ich wünsche mir einen Wissenden, um für meinen Schmerz ein Heilmittel zu bekommen.

3. Ich habe keinen Hunger, ich bin kein Schmarotzer. Ich brauche niemanden.

4. Ich wünsche mir Gott, der die Welt schuf.

5. Ich wünsche mir Yārān, die in Uzumdäl, Dikdaban, Yeddiqädäm, Qizqapan

6. Und in Älänja, Näxjävān, Ordūbād leben,

7. Die weit weg von Gärgär, Zünüz, Șūfyān und Märänduz (leben).

8. Die unten in Šänb-i Ġazan, in Tabriz lebenden Yārān wünsche ich mir.

9. Die in Ārān gebliebenen, die Yārān in 'Eyn 'alī,

10. Die mit den nomadischen Turkmenen lebenden Karawanenführer-Yārān wünsche ich mir.

11. Die Yārān, die im Winterquartier in Äräsbārān und in allen Sommerquartieren leben. 
12. Die im Winter in Tuklıdag blühenden Frühlingsnarzissen wünsche ich mir.

13. Er zeigte sein Gesicht von Anfang an, später verbarg er es.

14. Ich wünsche mir bis zum letzten Tag der Welt, dieses Gesicht wieder zu sehen.

15. Ich verkaufe Stoffe aus Bägdād, ich tausche Nachrichten aus.

16. Ich wandere von Stadt zur Stadt und wünsche mir ein geliebtes Gesicht.

17. Der Handel bei Quščığlı ist Handel mit den Yārān.

18. Ich verkaufe perlenartige Waren und wünsche mir einen Kunden (ich erkündige weise Sachen und wünsche mir einen Zuhörer). 


\section{Kälām Nr. 151}

1. āxırätda var olmaqa dīn o īmānı istäräm

2. `āläma gämxōr olmaqa o bīgumānı istäräm

3. Äränlärdan sāya yetär ona Häqqdän vayäh yetär

4. jümla ‘āläm paya yetär män o xärmānı istäräm

5. Äränlär oxür Yāsīnı Älıfı Beyı Yā Sīnı

6. o xärmānin äyäsinı ovlī Xānı istäräm

7. żāhır bāṭın Äränlärı Yār lıqāsı Yārālärı

8. geyb ẹvinda gäzänlärı Šāh-1 Märdānı istäräm

9. Qulog̉l1 Häqqa yetešdi qüdrät bādasındän ičdi

10. Äyyub kimi därda düšdi därda därmānı istäräm

1. Für die künftige Welt wünsche ich mir eine Religion und einen Glauben, um weiter leben zu können.

2. Ich wünsche mir den, der zweifellos (Gott) ist, um für die Welt ein Mitfühlender zu sein.

3. Im Schatten (Schirm) der Sieben Wesen gibt es Schutz für denjenigen, dem die Wahrheit hilft.

4. Die ganze Welt bekommt ihren Anteil. Ich wünsche mir den Kornhaufen (Alles).

5. Die Sieben Wesen studieren Yāsīn (ein Kapitel des Korans) von Alef und Be bis Ya und Sin (von A bis Z).

6. Ich wünsche mir den Herrn des Kornhaufens mit seinem heiligen Xān (Äḥmäd).

7. Das Gesicht der Yārıstān in der Öffentlichkeit und im Geheimleben ist das beliebteste Gesicht von `Älī.

8. Ich wünsche mir den König der Herren ( Xāna) zugänglich ist.

9. Quloğl erreichte die Wahrheit. Er trank aus dem Weinbecher der Macht.

10. Wie Äyyūb der Prophet bekam er eine schmerzhafte Krankheit ${ }^{173}$. Ich wünsche mir jetzt die Heilung von meinen Schmerzen.

\footnotetext{
173 Äyyūb ist ein Prophet in Sinai. Er ist in der Tora und im Koran für seine Geduld bekannt. Meine Mutter, Monire Äḥmädī erzählte, dass Äyyūb eine unheilbare Krankheit hatte und sehr geduldig mit ihr umging. Sein Körper war mit zahlreichen eiterigen Verwundungen bedeckt. Die Wurmen fielen aus diesen Verwundungen raus. Äyyūb brachte sie auf seinen Körper zurück.
} 


\section{Kälām Nr. 175}

1. umīdim gämxōrim Yārdor äzäldän

2. umīdim o därgāha vārdor äzäldän

3. Äränlär ärkānı o kāyınātdan

4. mäğrıbdän mäšrıqa gülzārdor äzäldän

5. äläst gününda bälī deyänlär

6. olar inkār däyür iqrārdor äzäldän

7. bir gövhär gäldı o kāyınātdan

8. nıčča șärrāflär ona xärīdārdor äzäldän

9. İbrāhīm ĵāmundan šärbät ičänlär

10. olar ayıq däyür mäst o xumārdor äzäldän

11. därdlı olanlar Jäma surünsun

12. jämī̄e därda Jäm tīmārdor äzäldän

13. Yārānlär Quščıg่lı gövhär kānundan

14. tutubdor yükünı purbārdor äzäldän

1. Yār ist meine Hoffnung und mein Erbarmer von Anfang an.

2. Ich habe die Hoffnung auf den Königsthron von Anfang an.

3. Das Fundament der Sieben Wesen in diesem Weltall,

4. Vom Westen bis zum Osten, ist ein Blumengarten von Anfang an.

5. Die Leute, die von Anfang an „Ja“ zur Wahrheit sagten,

6. Sind nicht skeptisch und sind akzeptabel von Anfang an.

7. Eine Perle kam aus dem Universum.

8. So viele Kenner wollten sie kaufen von Anfang an.

9. Die Leute, die aus dem Weinkelch Ibrāhīms tranken,

10. Sind nicht nüchtern, sie sind betrunken von Anfang an.

11. Alle Leidenden werden zum Jäm geschickt.

12. Jäm ist das Heilmittel gegen alle Schmerzen von Anfang an.

13. Yārān, wisst Bescheid, dass Quščığlı aus der Perlenquelle

14. Seinen Anteil bekam und voll Weisheit ist von Anfang an. 


\section{Kälām Nr. 183}

1. här däm sübḥānıma jāâr eyläräm män

2. bir āh čäksäm ‘ālämi nār eyläräm män

3. deyirdün sıčäräm Ḥäqqi nāḥäqqdän

4. nıččä min yoxlari var eyläräm män

5. bašımi Šāh-1 ‘ 1 q̌qa märdāna vırräm

6. siginsam nāmūsıma `ār eyläräm män

7. bülbül täk hạasrätäm o gül yuzuva

8. bülbülı gülšända zār eyläräm män

9. gözlärımdän axan bu qanli yašlar

10. gähī neysān gähī qar eyläräm män

11. Kälām-1 qädīm var Gūrān ičinda

12. indi Türkıstāna jāâr eyläräm män

13. Šähsävārog̉lyam ačdım dükānim

14. Yārilän bıy o bāzār eyläräm män

1. Ich rufe ständig meinen Gott.

2. Wenn ich einmal seufze, mache ich die Welt zum Feuer (verbrenne die Welt).

3. Du sagtest, dass du das Wahre vom Unwahren trennst

4. Und mehrere tausend Nichtse zum Dasein bringt.

5. Ich widme kühn meinen Kopf dem König der Liebe.

6. Wenn ich Leidenschaft bekäme, würde ich meine Ehre zu Schanden machen.

7. Wie eine Nachtigall wünsche ich mir dein blumenartiges Gesicht

8. Und bringe die Nachtigall im Blumengarten zum Jammern.

9. Die blutigen Tränen fließen aus meinen Augen.

10. Manchmal werde ich zum Mairegen, manchmal schneie ich.

11. Das alte Kälām war bei dem Gūrān-Volk,

12. Jetzt schreie ich für Turkistan.

13. Ich bin Šähsävārog̉ı (der Dichter) und mache mein Geschäft:

14. Mit dem Yār verkaufe ich und gewinne. 


\section{Kälām Nr. 197}

1. bir `żīm xälīfa gälür gıdiräm sälāmä qarši

2. čalonür țäbl-1 Häqīqät Pādıšāh-1 ${ }^{\circledR}$ ālämä qarši

3. qutludor Yārin qädämı Häqq dīvāndän gälür

4. yüzmüz ustä varax qutlu qädämä qarši

5. Kırdārı pīš olanün nüṭq1 onün durdānador

6. parčähdän bulan qalxan Pādıšāh-1 'ālämä qarši

7. Pādıšāhum mundä gäldi räḥmätilä beylä gälsun

8. gälün gälün beylä varax Pādıšāh-1 'ālämä qarši

9. günähkār bändayäm bälkä baġušlyalar

10. nātämām bändayäm indı gälmišäm tämāmä qarši

11. mänım Ḥäqqım İbrāhīmdor ḥäqq dımišäm İbrāhīma

12. čaqurram adin `āläm o āškārä qarši

13. Yārānlär üč gün oroĵ tutub bällı qalub bayrami

14. Xōĵasi Quščıg̉lını söyöndor bayramä qarši

1. Ein großer Kalif kommt: ich gehe ihm entgegen, ihn zu grüßen.

2. Die Wahrheitstrommel wird dem König der Welt entgegen trommeln.

3. Der Schritt von Yār ist gesegnet: die Wahrheit kommt vom Dīvān (Gerichtshof Gottes).

4. Unsere Gesichter richten sich dem gesegneten Schritt entgegen, lasst uns hingehen.

5. Die Rede vom Diener, der Kırdār zu bringen vorhat, ist wie eine Perle;

6. Auf einmal steht dieser Yār auf, um sehnsuchtsvoll zum König der Welt zu gehen.

7. Mein barmherziger König ist angekommen. So sei willkommen.

8. Kommt, kommt, so gehen wir dem König der Welt entgegen.

9. Ich bin ein sündiger Knecht, vielleicht werde ich begnadigt.

10. Ich bin ein unvollkommenes Geschöpf. Jetzt bin ich vor den Vollkommenen (Gott) gekommen.

11. Meine Wahrheit ist İbrāhīm. Ich rede über İbrāhīm die Wahrheit.

12. Ich rufe seinen Namen öffentlich vor der ganzen Welt.

13. Ihr Yārān, fastet drei Tage und macht an dem bestimmten Tag ein Fest.

14. Der Herr von Quščıg lı macht ihn an diesem Festtag fröhlich. 


\section{Kälām Nr. 215}

1. Pādıšāhin näżäri xātūn Bäšīra

2. kimin nä ḥäddi var bu sırra ira

3. Bınyāmīn Dāvūd Pīr Mūsī Rıdāni

4. Xıdmät xānasinä ṣıdqilän gira

5. bir näżär eylädı xātūn Bäšīira

6. Yeddilärı o dämdä gätdı zuhūra

7. Äränlär jumlasi mu äțțäl qaldi

8. hıč birı irmädi bu gizlin sırra

9. sutūna Pādıšāh xurūša gäldi

10. dilkä kim diladi qudrät-1 Pīra

11. däryānun ičinda xātäm salanda

12. hävār kim apardi häẓrät-1 Mīra

13. gūyända Nämāmä umīdvār ol

14. ṣıdqilän yapuš Xāvändıgāra

1. Der König schenkte der Herrin Bäšīra besondere Aufmerksamkeit:

2. Niemand darf dieses Geheimnis nachvollziehen.

3. Bınyāmīn, Dāvūd und Pīr Mūsī

4. Traten ins Haus wie ehrliche Diener ein (dem König wahrhaftig zu dienen).

5. Als Er (der König) die Aufmerksamkeit der Herrin Bäš̄ira schenkte,

6. Erschienen in diesem Moment Häft/tävān (die Sieben Mächte) auf der Welt.

7. Die Sieben Wesen erstaunten vor dem Geschehen.

8. Keiner von ihnen konnte dieses Geheimnis nachvollziehen.

9. Der König rief laut:

10. „Wer gab dem Pīr (dem Binyāmīn) die Macht (zu verstehen)?

11. Als ich den Ring ins Meer hineinwarf,

12. Wer brachte diese Nachricht dem Heiligen Mīr?““

13. Du Nämāmä, bleib immer hoffnungsvoll

14. Und in ehrlicher Verbindung zu Xāvändıgār. 


\section{Kälām Nr. 227}

1. gälün gälün ey Yārānlär qulaq asun bu dästāna

2. ičun Xōjäm šärbätindän äsräk olun mästāna

3.dildä söyläräm dästānı gözläräm čăšm-1 mästānı

4. dolandım Rūmıstānı güzārım düšdı bustāna

5. gözımä göründi bir Är '`āläm oldı münävvär

6. aldım gövhär satdum gövhär erišdim mä dän-1 kāna

7. Āb-1 Ṭäšārdän ičildı räḥmätı Yāra sačuldı

8. hızārān güllär ačoldı bülbül oldum gülästāna

9. Quščığlı oxür näsinı Älıfı Bıyı Yāsīnı

10. čäkärdı Bārgāh ārzūsinı Äränlär yetdılär sāna

1. Kommt, kommt ihr Yārān, hört euch diese Geschichte an.

2. Trinkt Šärbät (Wasser aus der Ṭäšār-Quelle) von meinem Herrn, seid betrunken.

3. Mit meiner Zunge erzähle ich diese Geschichte und beobachte eure durch Šärbät betrunkenen Augen.

4. Reisend durch Rūmıstan (Byzanz ), kam ich zu einem Blumengarten.

5. Ich sah dort einen Herrn. Als ich ihn sah, fing die Welt an, zu strahlen.

6. Ich kaufte eine Perle - ich verkaufte eine Perle: so näherte ich mich der Perlenmine.

7. Als ich die Perlenmine erreichte, trank ich Wasser aus der Ṭäšār-Quelle.

Das Herz Gottes nahm mich an.

8. Tausende Blumen blühten im Garten auf. Ich wurde zu einer Nachtigall in diesem Garten.

9. Was liest Quščıġlı? Das Alphabet oder den Yāsīn (eine Sure aus dem Koran)?

10. Als er (Quščığli) sich wünschte, den Thron der Sieben Wesen zu sehen, hielten sie (die Sieben) vor ihm die Parade. 


\section{Kälām Nr. 234}

1. Yārānlär oġradum Šāha bu geĵa

2. fäläk uzundähkı māha bu geja

3. jämālun gördum xeylī šād oldum

4. süjūu eylädum därgāha bu geĵa

5. äl surubän tutdum gül dāmänindän

6. dedi oxi sūra-1 Ṭāhā bu geja

7. dedim yā ‘̈̈lī vır gäl mürādum

8. dedi vırdim mürādin hā bu geĵa

9. Quščioġlı `Älī żkrin idärkän

10. og̉radı gänĵ-1 nāgāhā bu gềa

1. Ihr Yārān, in dieser Nacht traf ich den König.

2. Ich sah in dieser Nacht im Universum den stehenden Mond.

3. Ich sah sein hübsches Gesicht und wurde sehr glücklich.

4. Ich betete in dieser Nacht am Hof (Gottes) an.

5. Ich streckte meine Hand aus, um mich an seinem Hemdzipfel zu halten.

6. Er sagte zu mir: „Lies in dieser Nacht aus dem Koran die Ṭāhā-Verse vor“.

7. Ich sagte: „Du `Älī, erfülle meinen Wunsch“.

8. Er sagte: „Du bekommst die Erfüllung in dieser Nacht“.

9. Als Quščiog̀lı das Lob für 'Älī sang,

10. Bekam er unerwartet einen Schatz. 


\section{Kälām Nr. 288}

1. yaradan handador kān o mäkāni

2. leyl o nähār čaqürram män oni

3. yaratdı äzäl pīšinndän yäkdāna gövhär

4. öz1 ondäydı beylä mädani

5. näżär čı̌̌milän gövhärä baxdi

6. ärıdi su oldi tutdi jähāni

7. kavpugundän kuski saldi dağlara

8. tüsdusindän yaratdi o āsımāni

9. Äränlär čärx usta čaldi qälämi

10. dünyā Gāv o māh usta tutdi qärāri

11. yeddı yerdän yeddı gögdän yuqurdi

12. bir avuč torpaxdan dozdi ādami

13. at gäldi ādämin qālıbini pöza

14. göbägindän yaratdi o pāsıbāni

15. yeddiyuz yetmiš iyl qaldi gil gävadä

16. dortyuzqirxdort rägä vırildi jāani

17. jâan ‘išqdän ayrıdor māddī tändä

18. sāz gäldi `išqilän bäglädi ĵāni

19. näfäs bir bir gälür rängi bilünmäz

20. tanumaq olmäz o bīnıšāni

21. Ādäm aqsurübän äyaqa dürdi

22. dilinä gätürdi šükr-1 sübhạnni

23. mälāyıklär Ādäma süĵada qildilär

24. Ādämdä täḥqīq itdilär Räḥmāni

25. `Äzāzīl Ādämä qilmädi süĵ̀da

26. böynüna gıčıtdi țövq-1 Šeyțāni

27. ag̉latdün ag̉latdün gäl indi güldür

28. tıšnayäm gürsnayäm ey käräm kāni

29. ägär danıq ählısän täšvīšä düšmä

30. odür 'ālämlärın rızq vırani

31. biz o Zärdakäluq rūz-1 äzäldänuq

32. önünčün dutmušüq jüumla jähāni

33. özidi Rüstäm-1 pīltän-1 Zāl 
34. yäknäfäsa ačdi Māzändärāni

35. māl o jāanin qeyan čoxdor jähānda

36. pählävān sayallar ĵānä qeyani

37. onsäkkizmin ‘āläm sırrindä peydā

38. yetmišikki dildä söylär zäbāni

39. gälün tärk eylalim o ki fänādor

40. tutalim bäqāni häm jāâvıdāni

41. atun xod fänāni tutun bäqāni

42. zınhār zınhār o bīgümāni

43. jähāni Äḥmädä bilindirdün

44. ābādān eylyä jümla vīrāni

45. soraqšun otgän oldi bil Quščığl1

46. sıkka-1 Äḥmädī oldı rävānı

1. Wo ist der Schöpfer der Welt und der Existenz?

2. Tage und Nächte rufe ich ihn.

3. Er schuf in der Vorzeit eine einzige Perle.

4. Er war selbst in der Perle, wovon keiner wusste.

5. Er blinzelte die Perle an -

6. Die Perle taute auf und wurde zu Wasser und machte die Welt voll von Wasser.

7. Aus Perlmutt baute er Gebirge auf.

8. Aus dem Taudampf schöpfte er den Himmel.

9. Die Sieben Wesen schrieben auf dem Himmelsgewölbe.

10. Die Welt ruhte sich auf dem Stierhorn und dem Mond aus.

11. Die sieben Schichten der Erde und die sieben Schichten des Himmels rollte er aus.

12. Aus einer Hand voll Lehm hat er den Menschen geschaffen.

13. Ein Pferd kam, die Menschengestalt zu zerstören.

14. Aus seinem Nabel schuf er einen Wächter.

15. 770 Jahre blieb der Körper aus Lehm weiter liegen.

16. Dann wurde Leben zu den 444 Venen gegeben.

17. Ohne Liebe blieb das Leben aber nicht im Körper.

18. Der Körper und die Liebe harmonierten und nahmen Leben an.

19. Nachher konnte man einatmen und ausatmen ohne dieses zu merken: 
20. Diese haben kein Kennzeichen und sind nicht zu erkennen.

21. Der Mensch nieste und stellte sich auf seine Beine.

22. Er brachte seine Dankbarkeit vor Gott zur Sprache.

23. Die Engel verneigten sich vor dem Menschen bis zur Erde

24. Und bestätigten die Schöpfung Gottes.

25. Der Teufel verneigte sich aber vor dem Menschen nicht:

26. Er hängte um seinen Hals die Satanische Kette (den ewigen Fluch).

27. Oh, Gott! Brachtest du den Zuhörer zum Weinen, bring ihn aber jetzt zum Lachen.

28. Ich habe Durst, ich habe Hunger. Du, die Quelle der Großzügigkeit,

29. Wenn du die Wahrheit verstehst, hab keine Sorge:

30. Gott ist der Nahrungsgeber für alle Welten.

31. Wir sind von Anfang an die Kalzärda (die Opfertier) und gehören dem Anfang der Schöpfung.

32. Wir sind in der ganzen Welt für Gott.

33. Er (Dāvūd) war selbst Rustäm-1 Zā $1^{174}$, der größte Held

34. Und besiegte Māzändärān ${ }^{175}$ in einem Augenblick.

35. Es gibt auf der Welt viele Menschen, die ihr Leben und ihr Eigentum gerne Gott widmen möchten.

36. Aber derjenige, der sein Leben Gott widmet, wird wohl als Held anerkannt.

37. 18000 Welten sind in deinem Geheimnis klar zu sehen.

38. In 72 Sprachen wird über dich gesprochen.

39. Lasst uns die Sterblichen verlassen.

40. Wir nehmen das mit, was ewig und unsterblich ist.

41. Werft das weg, was sterblich ist, und nehmt das mit, was ewig ist.

42. Achtung! Achtung! (Der Ewige) ist der, der ohne Zweifel ist.

43. Xān Äḥmäd (ein Xānıdān-Gründer) lernte die Welt mit deiner Hilfe kennen.

44. Er baut alle zerstörten Orte wieder auf.

45. Rechne Quščioġlu als einen erfolgreichen Suchenden.

46. Jetzt ist die unsterbliche Souveränität des Xān Äḥmäd anerkannt.

\footnotetext{
${ }^{174}$ Rustäm-1 Zāl ist der Name eines Helden im iranischen Epos (vgl. Firdousi 1373 (1994), Band 2, S. 91-127).

${ }^{175}$ Māzändärān ist eine Provinz im Nord-Iran. Dort befand sich ein der Schlachtfelder von Rustäm-1 Zāl (vgl. Firdousi 1373 (1994), Band 2, S. 117-124).
} 


\section{Kälām Nr. 289}

1. yaradan handador Kān o Mäkāni

2. yārānlär čaqorun o lāmäkāni

3. Yā donda yaratdi yerilän gögi

4. Dāvūd o Bınyāmīn pīr Mūsī nāmi

5. o dämdä Yeddiläri gätdi żuhūrä

6. Rämzbār gäturdi sufra häm nāni

7. oni bäxš itdi pīr o pīšvāyä

8. čalundi täkbīri qildi änjāmi

9. Äkbärilän män vırdim baši

10. Kākā donunda Rıdāni tani

11. Ḥüseynilän bāhäm bašımi vırdim

12. gäl indi bašımi käsäni tani

13. 'Älī šä'nundä xätm oldi Däftär

14. Qulog̉lı soilyub bu Säränjāmi

1. Wo ist der Schöpfer der Welt und der Existenz?

2. Ihr, Freunde, ruft ihr diesen, der keinen Platz besetzt.

3. Er schuf während der Gestaltung von $\mathrm{Ya}^{176}$ den Himmel und die Erde.

4. Seine weiteren Schöpfungen heißen Dāvūd, Bınyāmīn und Pīr Mūsī.

5. In diesem Moment schuf er die Sieben Wesen.

6. Rämzbār brachte eine Decke und Brot.

7. Sie verteilte das Brot an den Führer und den Obersten.

8. Das Gebet wurde gesprochen, und die Erfüllung fand statt.

9. Wir opferten mit Äkbär ${ }^{177}$ zusammen unsere Köpfe.

10. Erkenne den Körper von Kākārädāyî1 ${ }^{178}$.

11. Wir opferten mit Hoseyn unsere Köpfe.

12. Komm her und erkenne meinen Mörder.

13. Mit der Würde 'Ālīs ist das Heft beendet.

14. Qulog̉lı dichtete dieses Säränĵām (Kälām).

\footnotetext{
${ }^{176}$ Ya ist die zweite Ära der Weltschöpfung, wobei Sulțān Säḥāk sich als Gott erkennen ließ.

${ }^{177} \ddot{A}$ kbär ( ${ }^{` A} \mathrm{~A} \overline{1}$ Äkbär) ist der Name des Sohnes von Huseyn bzw. des Enkelsohnes von `Ālì (vgl. Dehkhoda 1968, Band 35, S. 138).

${ }^{178}$ Kākāyī (oder Kākārädāyī) ist eine Verkörperung von Bınyāmīn, auch ein Historiker der Yārıstān.
} 


\section{Kälām Nr. 296}

1. yol ustundä oturubdur yalunqaĵi

2. Ḥäqqi söyänlär olublar aĵi

3. mägrrıbdän mäšrıqä atlosı yerur

4. `ālämlär Dāvūdä virälär bâĵi

5. gör na oyunčidor meydān ičindä

6. däryānun altunda qizdirir sâ̂i

7. här kim bir göyöl älä gätürsä

8. yetırob bārgāhä olubdor ḥāĵ̄

9. xälāyıqlär sizi rädda oxürlar

10. xälāyıqlär dyänin olubdor nâ̄̄̄

11. dünyāni goturdi tuxm-1 däjjāāl

12. deyärlär yalani qoyullar tâji

13. Quščığlı pīrivun dedigini tut

14. pīrivun sozinä gätormä raĵi

1. Ein Anspruchsvoller sitzt auf dem Wege und sieht alle herausfordernd an.

2. Die Wahrheitsliebenden sind aber bitter (hässlich) geworden.

3. Von Westen bis Osten reiten die Ritter Sulțān Sähākss.

4. Das Weltall gibt Dāvūd (Sulțān Säḥāks Armeeführer) seinen Tribut.

5. Guck, was für ein Wunder er (Sulțān Säḥāk) schaffen kann:

6. Er kann unter dem Meer eine Backofenpfanne erhitzen (die Sonne schöpfen ${ }^{179}$ ).

7. Wenn jemand ein Herz glücklich macht,

8. Dann ist er schon ein Häddschi ohne nach Mekka zu gehen.

9. Die Anderen nennen euch „Abfall““.

10. Sagt zu diesen Menschen, dass diese Abfälle jetzt Retter geworden sind.

11. Die Rassen des Antichristen eroberten die Welt,

12. Sie lügen und tragen die Krone.

13. Du, Quščıg̀lı, bestätige die Worte deines Pīr

14. Und rede nicht gegen sein Wort.

\footnotetext{
${ }^{179}$ Die Sonnenschöpfung fand in der Yā-Ära statt.
} 


\section{Kälām Nr. 297}

1. äzäldän söymušüq bizdä o Šāhi

2. olarün yārıdor sırr-1 ilāhī

3. Müḥmmäd Mi rāâä vardiqi geĵa

4. dilärdi görsun o Pādıšāhi

5. yuxari varuban Aṣlanı gördi

6. vırubän üzük1 aldi rāh1

7. doqsanmin käläma deyildi Muḥämmädä

8. atmüšminindä oldi näzahi

9. ottozmin sırrdor ${ }^{e}$ Älī yanunda

10. Muhämmäd bilmädi o däm Mövlāni

11. ašaq1h varubän āvāz ešitdi

12. gördi ki söylänur sırr-1 ilāhī

13. xādımolfüqärā deyubän ačuldi qapo

14. gördi ki ägläšub Q1rxlärin Šāhi

15. Q1rxlär söradi yā Muḥämmäd na gördün

16. alobän üzügün qildi nıgāhi

17. Q1rxlärin birınä nīštär vuroldi

18. Q1rxindän dä beyla qan oldi näzahi

19. äzıldi g1lla ičildi šärbät

20. sär mäst olubän tutdi sämāhi

21. Quščığlı quldor Dīvān dän gälur

22. söylanan Ḥäqqdor Jämdor güvāhi

1. Von Anfang an liebten wir auch diesen König.

2. Das Geheimnis Gottes beschützt sie (die Yārān) immer.

3. In der Nacht, als Muhammad zum Himmel fuhr,

4. Verlangte er, diesen König zu sehen.

5. Als er höher fuhr, sah er den Löwen Gottes ( $\left.{ }^{\circ} \ddot{l} l \bar{i}\right)$.

6. `Älī gab ihm einen Fingerring. Er (Muhammad) fragte `Älī nach dem Weg.

7. Muhammad wurden 90 tausend Worte gesagt.

8. 60 tausend davon waren zu verstehen.

9. 30 tausend davon sind ein Geheimnis `ëlīs.

10. Muhammad konnte das Ganze nicht nachvollziehen. 
11. Als Muhammad wieder herunter kam, hörte er eine Stimme.

12. Er sah, dass das Geheimnis Gottes schon erzählt wurde.

13. Er sagte, dass er ein Diener der Elenden sei, dann wurde ihm die Tür geöffnet.

14. Er sah, dass der König der Vierzig Personen dort saß.

15. Diese Vierzig Personen fragten Muhammad, was er sah?

16. Sie nahmen den Fingerring und schauten ihn an.

17. Einer der Vierzig Personen wurde mit einer Lanzette gestochen,

18. Darauf war das Blut bei allen Vierzig zu sehen.

19. Eine Weinbeere löste sich in Šärbät ${ }^{180}$ und wurde ausgetrunken.

20. Alle wurden betrunken und fingen an, zu tanzen.

21. Quščioġl1 ist ein Diener, er kommt vom Dīvān (Gerichtshof Gottes)

22. Und erzählt die Wahrheit, seine Zeugen sind die Jäm (Vierzig Personen).

180 Šärbät ist einfaches Wasser, das die Țäšār-Quelle symbolisiert und nach jedem Abendessen im Jäm getrunken wird. 


\section{Kälām Nr. 310}

1. ‘āšıq-1 sär mäst olan gözdän gičirmäz sāqīni

2. bīgümān ičär älındän sāqīnun rädāqini

3. Kä`ba-1 Beytolhärām gördöm uzundä bīgümān

4. süĵ̉dagāh män etmišäm o qašlarun miḥrābini

5. söydum ävväl żülmāt zülfün irdim Āb-1 Kovṣärä

6. lämyäzälin xämrindän ičdim bildim aldum ‘ümr-1 bāqīni

7. āb o ātäš xāk o bād dandur bu `ìīm xānadä

8. Ḥäqq1 täḥqīq eyläyub gör `āšsqin idrāqīni

9. Qulvälīnun dilbärısän bir qädäm bas gäl bizä

10. barča ki män bulmušäm bu göylumun rövnāqini

1. Der betrunkene Verliebte lässt den Schenk nicht aus dem Auge (ein Yār denkt immer an Gott).

2. Er trinkt ohne zu zweifeln von der Hand des Schenks aus seinem kostbaren Weinpokal immer weiter.

3. Ich sah in seinem Gesicht ohne zu zweifeln das heilige Haus der Kaaba.

4. Ich sah in seinen Augenbrauen für mich den Mihrab (den Ort des Gottesdienstes).

5. Ich freute mich zuerst wegen seiner schwarzen Haare und dann ging ich in den Kovsär-Brunnen hinein.

6. Ich trank vom ewigen Wein Gottes (ich erhielt die Kälām-Hefte), dann bekam ich das ewige Leben.

7. Wasser, Feuer, Erde und Wind sind bedeutend in diesem edlen Haus, wo Ordnung das Hauptprinzip ist.

8. Ich suchte nach der Wahrheit, ich fand die Wahrheit. Siehe, was für Kenntnisse der Verliebte besitzt.

9. Du bist der Geliebte (Gott) von Qul-Välī, mach noch einen Schritt weiter und komm zu uns.

10. Wenn du kommst, wird mein Wunsch glänzend (erfüllt). 


\section{Zusammenfassung und Aussicht}

In der vorliegenden Untersuchung wurden heilige Texte der religiösen Gemeinschaft der Yārıstān, die ihre Mythologie, ihre Weltanschauung, ihre Moral und Rituale enthalten, aus ethnologischer, kulturgeschichtlicher und teilweise literarischer Sicht analysiert und interpretiert. Dies war nur deswegen möglich, weil der Verfasser selbst der untersuchten Gemeinschaft angehört.

Es wurde in der Arbeit gezeigt, dass das Gebilde aus sozialen und religiösen Strukturen innerhalb der Yārıstān-Gemeinde nur dank einer entwickelten religiösen Lehre in Form autorisierter Literatur, die von der älteren Generation der Yārıstān-Gläubigen an die jüngere Generation mündlich weiter gegeben wird, bestehen bleibt. Diese Literatur, die aus religiösen Gedichten und Predigten besteht, wurde aus einer mittel-west-iranischen Mundart des Türkischen transkribiert und übersetzt. Dafür wurde eine Transkription entwickelt.

Diese Promotionsarbeit ist nur ein der ersten Schritte zur Entdeckung des Yārıstān-Glaubens, der zum einen auf Grund des eigenen Hifz-e Äsrār-Prinzips (Bewahren der Geheimnisse) und des Täqyyä (Verheimlichung), zum anderen auf Grund der bis heute bestehenden Verfolgung seitens der theokratischen Regierung des Iran der Öffentlichkeit als eine ketzerische Sekte dargestellt wird. Es gibt immer noch Autoren wie Abdullā Xodābändeh (2004), der nach einem Vergleich zwischen der Yārıstān und dem Islam die Yārıstān-Gläubigen als „unvernünftig“, „unglaubwürdig“, „unsauber“ und „inakzeptabel“ bezeichnete (vgl. Xodābändeh 2004, S. 162-205). Der Autor kommt zu dem Schluss, dass die Yāristān außerhalb des Islam stehen und demnach „,unerlaubt“ und „sündig“ sind, also dem Kapitel des islamischen Gesetzes „B1d ät““ („Ketzerei“) unterliegen (vgl. Xodābändeh 2004, S. 166).

In dieser Arbeit wurden zum ersten Mal aus der Sicht eines Mitgliedes einer Yārıstān-Familie, der sich der wissenschaftlichen Vorgehensweise und der systematischen Forschung verpflichtet sieht, die originalen Inhalte des Yārıstān-Glaubens vorgestellt. Die Übersetzungen von Gedichten, die Kategorisierung der Begrifflichkeit, die Systematisierung der Glaubensentwicklung in der Darstellung der Manuskripte bietet eine Quelle von Materialien für weitere Untersuchungen:

- Die Kälāmāt-1 torkī kann als ein literarisches Werk von mehreren Dichtern betrachtet werden;

- Als eine Grundlage für eine religionshistorische Untersuchung kommen Sagen und Mythen der Yārıstān-Literatur in Frage;

- Es bieten sich Vergleiche der Yārıstān mit den benachbarten und zeitgenössischen Religionen an; 
- Die Mūsīqī-e Kälāmī wartet auf Musikethnologen und öffnet womöglich einen Zugang zur altiranischen Musik.

Die drei Jahre, die dem Schreiben dieser Arbeit an der Georg-August-Universität Göttingen gewidmet wurden, fühlte ich mich meinem Volk sehr nah. Ich hoffe, dass mein Werk die Aufmerksamkeit der progressiven Wissenschaft auf die Probleme einer unterdrückten Minderheit im Iran lenkt und die kulturellen Schätze der Yārıstān der breiten Öffentlichkeit bekannt macht. 


\section{Literaturverzeichnis}

Anklesaria, Behramgore Tehmuras: Zand-Ākāsīh. Iranian or greater Bundahišn. Bombay 1956.

Bahar, Mehrdad: Forschung der iranischen Mythologie. Teheran 1996.

Boyce, Mary: A history of Zoroastrianism. Vol. 1. Early Period. Köln 1975.

Boyce, Mary: Zoroastrians. Their Religious Beliefs and Practices. London, Boston and Henley 1979.

Būstān, Bähmän / Därwišì, Mohämmad R.: Morūrī bär mūsīqī-e sonnätī wa mäḥllīee Irān [Ein Überblick über die traditionelle und der regionale iranische Musik]. Teheran 1370/1991.

Bruinessen, M. van: Haji Bektach, Sulțān Säḥāk, Shah Mina Sahib and various avatars of a running wall. In: Turkica $21 / 3,1991$, S. $55-73$.

Bruinessen, M. van: When Haji Bektash still bore the name of Sultan Sahek: notes on the Ahl-I Haqq of the Guran district. In: Popovitch and Veinstein, Bektachiyya: Études sur l’ordre mystique des Bektachis et les groupes relevant de Haji Bektach. Istanbul 1995.

Edmonds, C. J.: The beliefs and practices of the Ahl-i Haqq of Iraq. Iran 1969. S. 7, 89-106.

During, Jean: Le repertoire-modele de la musique Iranienne. Teheran 1991.

Firdousi, Äbolqāsım: Šähnāmeh. In 10 Bänden. Teheran 1373/1994.

Gobineau, Arthur de: Trois ans en Asie (de 1855 à 1858). Paris 1859.

Hamzeh'ee, Fariborz: An Introduction to the Investigations in Indigenous Knowledge and Oral Traditions of Western Iran. Kermanshah 2006.

Hamzeh'ee, Reza: Structural and organizational anlogies between mazdaism and sufism and the kurdisch religions. In: Gignoux, Ph., Gyselen, R.: Recurrent patterns in iranian religions from mazdaism to Sufism. Lésigny-France 1992.

Hamzeh'ee, Reza M.: The Yaresan. A Sociologikal, Historical and Religio-Historical Study of a Kurdish Community. Berlin 1990. 
Hinnels, R. John: Persian Mythology. London 1975.

Jeyḥūnābādi Ne'mät ollah: Šāhnāmeh-e Ḥäqīqät (Ḥäqq al Ḥäqāyiq) [Der Königsbrief der Wahrheit (Wahrheit aller Wahrheiten)]. Teheran 1985.

Kreyenbroek, P. G.: Mithra and Ahreman, Binyamin and Malak Tawūs. In: Gignoux, Ph., Gyselen, R.: Recurrent patterns in iranian religions from mazdaism to Sufism. LésignyFrance 1992.

Kreyenbroek, P.G.: On the Study of some heterodox sects in Kurdistan. In: Islam des Kurdes.Les Annales de 1’Autre Islam, n 5. Paris 1998, S. 164-184.

Kreyenbroek, P.G.: Religion and Religions in Kurdistan. In: Kreyenbroek, Philip, Allison, Christine: Kurdish Culture and Identity. London 1996.

Kreyenbroek, P.G.: Yezidism - its background, observances and textual tradition. New York 1995.

Kloepfer, R. : Die Theorie der literarischen Übersetzung. München 1967. S. 57.

Ma'aroufi, Moussa: Les Systemes de la musique traditionnelle de l'Iran (Radif). Teheran $1374 / 1995$.

Marzolph, Ulrich: Der weise Narr Buhlūl. In: Zeitschrift der Deutschen morgenländischen Geselschaft, Band XLVI. 4. Wiesbaden 1983.

Minorsky, Vladimir F.: „Материалы для изучения персидской секты „Люди истины“ или Али-илахи“. В: „Труды по востоковедению, издаваемые Лазаревским Институтом Восточных языков“. Выпуск XXXIII. [Materialien für die Untersuchung der persischen Sekte „Anhänger der Wahrheit“ oder „Ali-Ilahi“. In: „Werke der Ostwissenschaft des Lasarevskij Instituts der Östlichen Sprachen“. Heft XXXIII. Moskau 1911.

Minorsky, Vladimir F.: Notes sur la secte des Alhé-Haqq. Paris 1926.

Minorsky, Vladimir F.: Etudes sur les Ahl-i Haqq. In : Revue de 1'Histoire des Religions 97 / 1928, S. $90-105$.

Minorsky, Vladimir F.: Ahl-i Hakk . In: Gibb, Kramers et al. (eds.): Encyclopaedia of Islam. Leiden u. London 1960, S. 260-263. 
Mir-Hosseini, Z.: Inner truth and outer history: the two worlds of the Ahl-i Haqq of

Kurdistan. In.: International Journal of Middle East Studies 1994/16, S. 267-285.

Mir-Hosseini, Z.: Faith, ritual and culture among the Ahl-e Haqq. In: Kreyenbroek, Philip, Allison, Christine: Kurdish Culture and Identity. London 1996. S. 111-134.

Mokri, M.: Etude diun titre de propri6t \&... In: Contribution scientifique aux Studes iraniennes. Recherches de kurdologie. Paris 1970, S. 303-330.

Moradi, Golmorad: „Negahi gozära beh Tarix wa fälsäfeh-e Ähl-e-Ḥäqq Yārsān“ [,Ein kurzer Einblick in die Geschichte und Philosophie der Ähl-e Ḥäqq (Yārıstān)“]. Kista Sweden 1999.

Mounin, G.: Die Übersetzung. Geschichte, Theorie, Anwendung. München 1967.

Nour Ali Elahi: Borhān al ḥäqq [Argumente der Wahrheit]. Teheran 1974.

Omarhali, Hanna: Йезидизм из глубины тысячелетий [Yezidism aus der Tiefe der Tausenden von Jahren]. Sankt-Petersburg 2005.

Petruševskij, I. P.: Islam dar Iran [Islam im Iran]. Teheran 1350/1971.

Reza, E..: Aserbaidschan. Teheran 1367/1989.

Safizadeh, Seddiqh: Daneshnamahe nam avrane Yaresan [Berühmte Menschen der Yārıstān]. Teheran 1997 a.

Safizadeh, Seddiq: Namaye Saranjam [Der Brief der Erfüllung]. Teheran 1997 b.

Safizadeh, Seddiq: The review of Haftavaneh. Teheran 1983.

Spuler, Bertold: Iran in früh-islamischer Zeit. 1994.

Wagner, Ewald : Regeln für die alphabetische Katalogisierung von Druckschriften in den islamischen Sprachen. Wiesbaden 1961.

Xodābändeh, Abdulla: Šenāxt-e Ähl-e Ḥäqq Teheran 2004.

Yasemi, Rashid : Kurds and their historical/racial interrelation. Teheran 1936. 
Zärīnkūb, Ä̈bdolḥosseyn : Geschichte von den iranischen Völkern. In vier Bändern. $1371 / 1951$.

\section{Enzyklopädien und Wörterbücher}

Amīrxan: Wörterbuch Kurdisch. Teil 1: Kurdisch-Deutsch. 1. Aufl. Ismaning: Hueber 1992.

Aryanpour, A.A.: Deutsch-Persisches Wörterbuch. Teheran 1380/2001.

Brockhaus: Der Brockhaus Religionen. Leipzig/Mannheim 2004.

Dehkhoda, Ali Akbar : Loghat-Nama. Dictionaire Encyclopédique. Teheran 1968.

Devellioğlu, F.: Osmanlica Türkçe. Ansiklopedik Lugat. Ankara 1993.

Encyclopaedia Iranica: u. a. London 1985-2004.

Gemalmaz, E.: Azerî Türkçesi Lügati. Erzurum 1992.

Junker, H., Alavi, B. : Persisch-Deutsches Wörterbuch. Leipzig 1363/1984.

Langenscheid (Hrsg.): Arabisch-Deutsch/Deutsch-Arabisch: Berlin-München-Wien-ZürichNew York 1998.

Leyn, K. (Hrsg.): Grosswörterbuch Russisch-Deutsch. Moskau 2004.

Mä'lūf, Luis: Almonjid fi-el-loghah (Arabisch-Arabisches Wörterbuch). Beirut 1992.

Pifon, M.: Aserbaidschanisch-Persischer Lexikon. Teheran 1361/1983.

Rahmati, N.: Aserbaidschanisch-Deutsches Wörterbuch. Ruffel-Engelschaff 1999.

Wahrig, Gerhard: Deutsches Wörterbuch. Gütersloh 1968. 